UNIVERSIDADE DE SÃO PAULO

FACULDADE DE FILOSOFIA, LETRAS E CIÊNCIAS HUMANAS DEPARTAMENTO DE LETRAS CLÁSSICAS E VERNÁCULAS PROGRAMA DE PÓS-GRADUAÇÃO EM LETRAS CLÁSSICAS

CYNTHIA HELENA DIBBERN

O êthos de Aníbal em Tito Lívio e Cornélio Nepos: imagines

Versão corrigida

São Paulo

2013 
UNIVERSIDADE DE SÃO PAULO

FACULDADE DE FILOSOFIA, LETRAS E CIÊNCIAS HUMANAS DEPARTAMENTO DE LETRAS CLÁSSICAS E VERNÁCULAS PROGRAMA DE PÓS-GRADUAÇÃO EM LETRAS CLÁSSICAS

\title{
O êthos de Aníbal em Tito Lívio e Cornélio Nepos: imagines
}

\author{
Cynthia Helena Dibbern \\ Dissertação apresentada ao Programa de Pós- \\ Graduação em Letras Clássicas do \\ Departamento de Letras Clássicas e \\ Vernáculas da Faculdade de Filosofia, Letras e \\ Ciências Humanas da Universidade de São \\ Paulo, para a obtenção do título de Mestre em \\ Letras.
}

Orientador: Prof. Dr. Paulo Martins

\section{Versão corrigida}

São Paulo

2013 


\title{
RESUMO
}

A pesquisa analisa a construção do êthos do general cartaginês Aníbal nas obras de Cornélio Nepos e Tito Lívio, tendo em vista procedimentos retóricos. A primeira parte da pesquisa consiste no estudo do gênero historiográfico antigo, e sua relação com a Retórica, e ainda o estudo dos conceitos de êthos, écfrase e enárgeia. Analisamos então as estratégias discursivas de Tito Lívio para compor um caráter do inimigo adequado ao seu projeto historiográfico. Na segunda parte, discutimos os limites entre a bíos e história, e analisamos o êthos de Aníbal construído por Cornélio Nepos, o que permite discutir também as diferenças entre os gêneros, e outras questões gerais da obra do biógrafo.

\begin{abstract}
The research analyzes the construction of Hannibal's êthos in the works of Cornelius Nepos and Livy, considering rhetorical strategies. The first part is a study of ancient historiographical genre, and its relation to Rhetoric, and also of the concepts of êthos, ékphrasis and enárgeia. Then, we reflect about the discursive strategies used by Livy to compose a character convenient to his historiographical project. In the second part, we discuss the boundaries between bios and history and analyze the êthos of Hannibal built by Cornelius Nepos, what also allows us to discuss the differences between these genres and other general issues of Nepos' lives.
\end{abstract}




\section{Agradecimentos}

Agradeço à Fundação de Amparo à Pesquisa do Estado de São Paulo pelo financiamento de minha pesquisa.

Agradeço ao meu orientador Paulo Martins, por todo incentivo, apoio e inspiração desde os tempos de graduação, e por toda a disposição para promover o crescimento de seus orientandos. A ele devo também o tema da presente Dissertação.

Agradeço imensamente às professoras Elaine Cristina Sartorelli e Tatiana Oliveira Ribeiro por suas importantes sugestões e críticas, expostas não apenas no momento do exame de qualificação, mas em muitos outros eventos. Agradeço também a todos os professores que ministraram disciplinas de língua e literatura latina durante minha Graduação, e em especial aos professores Adriano Scatolin, Alexandre Hasegawa, Henrique Cairus e Breno Sebastiani, pela enorme contribuição com seus cursos de pós-graduação. Agradeço também ao professor Martin Dinter, por ter me proporcionado a oportunidade visitar o acervo da Biblioteca do Instituto de Estudos Clássicos da Universidade de Londres.

Agradeço a todos os amigos do grupo de pesquisa Imagens da Antiguidade Clássica (Lya Valéria Grizzo Serignolli, Henrique Verri Fiebig, Melina Rodolpho, Rosângela Santoro de Souza Amato, Cecília Gonçalves Lopes, Irene Cristina Boschiero, Gdalva Maria da Conceição, Gustavo Borghi e Simone Tonindel), pela parceria, amizade e troca de conhecimento ao longo de vários anos.

Agradeço à minha família, sem a qual nada faria sentido: aos meus pais, por todo esforço dispendido em minha formação escolar, à minha irmã pela amizade, e ao meu marido, minha alegria, por toda espécie de apoio sempre. Agradeço também a Deus, pela vida. 
ABREVIAÇÕES - AUTORES E OBRAS ANTIGAS

\begin{tabular}{|c|c|}
\hline Aphth. & Aftônio, Progymnasmata \\
\hline App., Syr. & Apiano, Síria. \\
\hline $\begin{array}{l}\text { Arist., Po. } \\
\text { De An. }\end{array}$ & $\begin{array}{l}\text { Aristóteles, Poética } \\
\text { De Anima }\end{array}$ \\
\hline $\begin{array}{l}\text { Cic., De Orat. } \\
\text { Fam. } \\
\text { De Fin. }\end{array}$ & $\begin{array}{l}\text { Marco Túlio Cícero, Do orador } \\
\text { Epístolas aos Amigos } \\
\text { De finibus }\end{array}$ \\
\hline Demetr., Eloc. & Demétrio de Falero, Sobre o Estilo \\
\hline $\begin{array}{l}\text { D.H., Lys. } \\
\text { Pomp. }\end{array}$ & $\begin{array}{l}\text { Dionísio de Halicarnasso, Lísias. } \\
\text { Epístola a Pompeu. }\end{array}$ \\
\hline D.L. & Diógenes Laércio, Vidas dos Filósofos Ilustres. \\
\hline D.S. & Diodoro da Sicília, Biblioteca Histórica. \\
\hline Enn., Ann. & Ênio, Anais. \\
\hline Hdt. & Heródoto, Histórias. \\
\hline Hermog. Prog. & Hermógenes, Progymnasmata. \\
\hline $\begin{array}{l}\text { Hor., Ars. } \\
\text { Carm. }\end{array}$ & $\begin{array}{l}\text { Horácio, Arte Poética. } \\
\text { Odes }\end{array}$ \\
\hline $\begin{array}{l}\text { Luciano, D.Mort. } \\
\text { Im. } \\
\text { Hist. Conscr. }\end{array}$ & $\begin{array}{l}\text { Luciano, Diálogo dos Mortos } \\
\text { Imagens } \\
\text { Como se escreve a história }\end{array}$ \\
\hline $\begin{array}{l}\text { Nep., Ages. } \\
\text { Alc. } \\
\text { Att. } \\
\text { Con. } \\
\text { Ham. } \\
\text { Han. } \\
\text { Milt. } \\
\text { Pelop. } \\
\text { Phoc. } \\
\text { Them. }\end{array}$ & $\begin{array}{l}\text { Cornélio Nepos, Agesilau } \\
\text { Alcibíades } \\
\text { Ático } \\
\text { Conon } \\
\text { Amílcar } \\
\text { Aníbal } \\
\text { Milcíades } \\
\text { Pelópidas } \\
\text { Fócio } \\
\text { Temístocles }\end{array}$ \\
\hline Nicol., Prog. & Nicolau, Progymnasmata \\
\hline $\begin{array}{l}\text { Plu., Aem. } \\
\text { Art. } \\
\text { Comp. Alex. Caes. } \\
\text { Flam. } \\
\text { Nic. }\end{array}$ & $\begin{array}{l}\text { Plutarco, Emilio Paulo } \\
\text { Artaxerxes } \\
\text { Vidas paralelas de Alexandre e Xerxes } \\
\text { Flamínio } \\
\text { Nícias }\end{array}$ \\
\hline Plb. & Políbio, Histórias \\
\hline Ps.Long. & Ps.Longino, Do Sublime \\
\hline Philostr., Im. & Filóstrato, o Velho, Imagens. \\
\hline Plin., Nat. & Plínio Velho, História Natural \\
\hline Quint., Inst. & Quintiliano, Institutio Oratoria \\
\hline Rhet. Her. & Retórica a Herênio \\
\hline $\begin{array}{l}\text { Sal., Cat. } \\
\text { Jug. }\end{array}$ & $\begin{array}{l}\text { Salústio, Catilina. } \\
\text { Jugurta }\end{array}$ \\
\hline $\begin{array}{l}\text { Suet., Aug. } \\
\text { Cl. }\end{array}$ & $\begin{array}{l}\text { Suetônio, Augusto. } \\
\text { Cláudio }\end{array}$ \\
\hline Tacit., Ann. & Tácito, Anais. \\
\hline Th. & Tucídides, Guerra do Peloponeso. \\
\hline Theon, Prog. & Teão, Progymnasmata \\
\hline
\end{tabular}




\section{SUMÁRIO}

Prólogo.

6

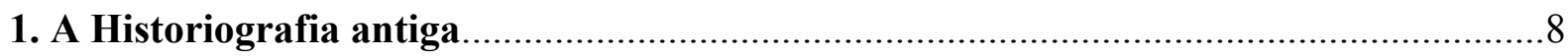

\section{História e Retórica}

2.1. A escrita da História: a Retórica e o "verdadeiro".. .25

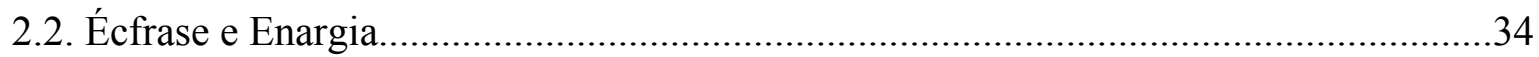

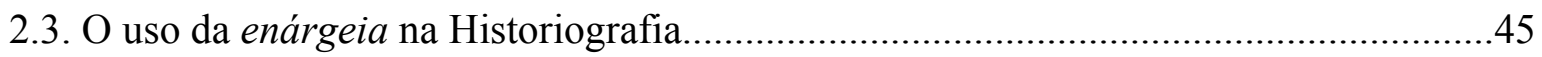

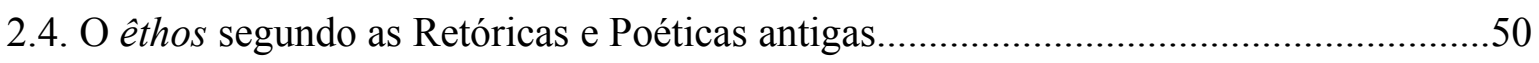

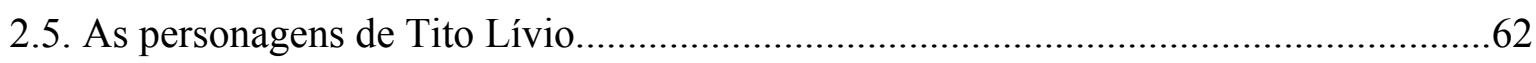

\section{Tito Lívio e o êthos de Aníbal}

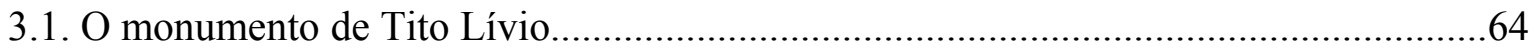

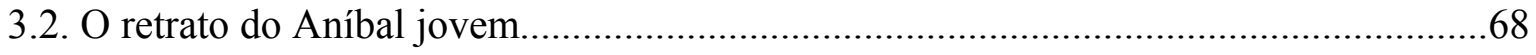

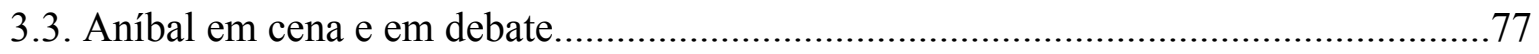

3.4. A decadência de Aníbal e a ascensão de Cipião Africano............................................99

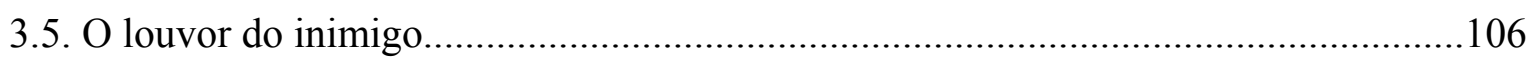

\section{O gênero biográfico e a Vida de Aníbal}

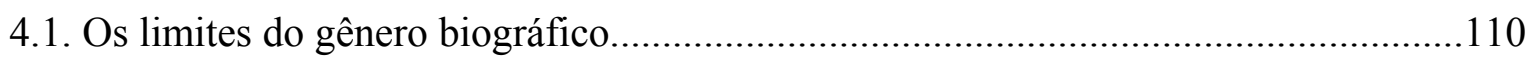

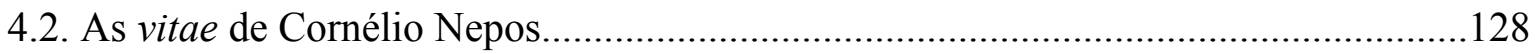

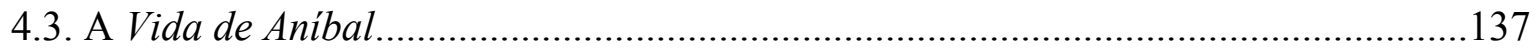

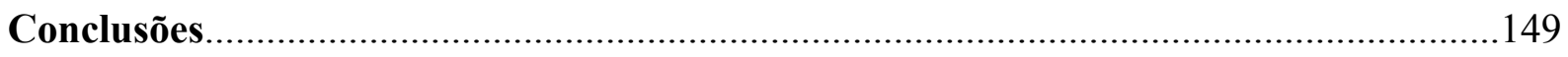

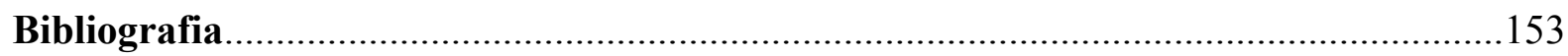

\section{Anexos}

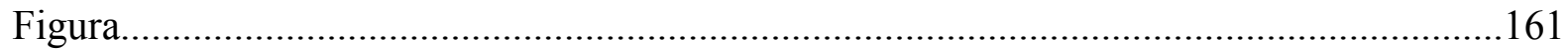

Tradução da Vida de Aníbal, de Cornélio Nepos.......................................................................162 


\section{PRÓLOGO}

Aníbal foi certamente um dos inimigos mais temidos por Roma. O cartaginês conduziu a Segunda Guerra Púnica em solo itálico e, depois de vencer grandes batalhas, por pouco não chegou aos portões da cidade. Podemos ter uma noção do medo que Aníbal representava aos romanos através provérbio popular latino "Hannibal ad portas", utilizado em situações em que havia perigo iminente ${ }^{1}$. Na literatura, foi retratado de maneiras diversas, muitas vezes como cruel e pérfido, e outras como um grande estrategista.

Nossa dissertação buscará analisar a construção do êthos desse general em duas obras: o Liber de excellentibus ducibus exterarum gentium, de Cornélio Nepos, e os Ab urbe condita libri, de Tito Lívio. Ambos os autores, o primeiro, scriptor vitae e o segundo, scriptor historiae, valem-se de procedimentos retóricos para criar, pela palavra, imagines ${ }^{2}$ do temível e obstinado inimigo romano. Veremos que, nas duas obras, o olhar para o outro é também um olhar para si. Nepos presenciara o fim da República e o governo dos Triunviratos, e parece discutir através das vidas de homens ilustres as mudanças pelas quais Roma passava. Tito Lívio, em sua juventude, presenciara também as guerras civis, mas escreve sua obra já no período imperial, uma História imensa, composta por 142 livros, que narram os acontecimentos de Roma desde a fundação da cidade até o ano 9 de nossa era. O historiador, que afirma em seu Prefácio que olha para o virtuoso passado romano para fugir dos males de seu presente, parece ver a história em termos individuais e morais; assim, muito dos acontecimentos da Segunda Guerra Púnica parecerão motivados pelo comportamento e êthos de Aníbal.

Buscamos primeiramente entender os conceitos de historía e bios entre os gregos e romanos, para a melhor compreensão do lugar do êthos do general nesses gêneros. Assim, a Dissertação inicia-se com o um estudo da Historiografia antiga e sua relação com a Retórica, uma vez que a construção da personagem é uma operação discursiva: êthos é o caráter que emerge pela linguagem. Nos detivemos brevemente no estudo teórico do conceito de êthos segundo as preceptivas retóricas e poéticas antigas, e também no de enárgeia, a vividez na descrição, e especialmente sobre seu uso na Historiografia, uma vez que o procedimento cumpre na narrativa de Lívio também importante papel na constituição do êthos de Aníbal.

\footnotetext{
${ }^{1}$ Lewis \& Short (1897, Hannibal); Cf. Cic. Fin. 4.9.22.

2 Utilizamos o termo imago em sua acepção mais geral, que indica uma similitude, seja ela uma imagem plástica, como uma escultura, ou uma imagem mental (imaginatio, phantasía) suscitada verbalmente. Para o estudo de termos técnicos da iconografia antiga, ver P. Martins (2011, 79-107).
} 
Após breve introdução sobre a obra de Tito Lívio, analisamos as passagens do historiador romano em que o êthos do cartaginês é pintado, e como tal caráter, construído ambiguamente, liga-se à concepção historiográfica do autor, que sugere frequentemente causalidades morais para explicar os rumos dos acontecimentos da guerra. A imago do general nos permitirá ainda discutir questões centrais da obra, como a relação entre romano e estrangeiro.

Embora a obra de Nepos seja anterior à de Lívio, trataremos primeiramente da última, pois a discussão sobre os limites do gênero biográfico é mais controversa, e será feita por contraste com as concepções de História. Assim, por último, investigamos os limites da bíos greco-romana, refletindo sobre seu possível surgimento e relação com a História e o encômio. Analisamos então a Vida de Aníbal de Cornélio Nepos, verificando como êthos do general é construído de maneira diferente neste outro território, e como Aníbal insere-se na série de vidas de Nepos, que convida o leitor a comparar os costumes estrangeiros e romanos.

Para todos os textos gregos citados no decorrer da Dissertação, nos esforçamos para encontrar uma boa tradução em língua portuguesa. Todavia, em alguns casos, só havia uma única opção disponível. Para os textos latinos, quando não foi encontrada nenhuma tradução de outros estudiosos, apresentamos uma tradução nossa, com o intuito de facilitar a compreensão do leitor. Os trechos citados da obra de Tito Lívio foram todos por nós traduzidos, assim como a Vida de Aníbal de Cornélio Nepos, que compõe um anexo à Dissertação, com o intuito de possibilitar a leitura em língua portuguesa de um texto ainda sem tradução publicada. A tradução visa somente à compressão do texto original, servindo de apoio ao restante do estudo. 


\section{A HISTORIOGRAFIA ANTIGA}

Este capítulo compreende uma breve reflexão sobre o conceito de historía desde os gregos até os romanos, buscando delimitar, de forma introdutória, o que foi o gênero historiográfico grego e latino. Tal estudo teórico faz-se necessário para a melhor compreensão de nossos objetos, e também para a tarefa futura de confronto de tal gênero com a biografia. Sabemos que nossa concepção moderna da História, pautada nos documentos, difere profundamente da maneira como os antigos entendiam o gênero historiográfico. Entretanto, nem mesmo entre os antigos parece ter havido uma unidade de pensamento, e assim, só podemos realizar tal estudo de maneira incompleta, visto que apenas parte dos trabalhos historiográficos chegou até nós, e de maneira nenhuma parece ter havido um consenso ou uma preceituação rígida sobre o gênero mesmo na Antiguidade, nem mesmo entre os autores canônicos. Determinar o que é adequado ao gênero historiográfico parece ter sido uma questão já controversa na Antiguidade; assim, nessa tentativa, corremos o risco de cometer generalizações.

John Marincola, seguindo os passos de Gian Biagio Conte ${ }^{3}$ em estudos de poesia latina, defende que o gênero não é um conceito estático, como um recipiente de ingredientes fixos contidos em uma obra, um conjunto de regras formais e inflexíveis que governam a criação de uma obra), mas é, sim, dinâmico e deveria ser vido como uma estratégia de composição literária ${ }^{4}$. Nesta visão, determinado gênero resulta da interação de estruturas de conteúdo e de expressão: é uma totalidade de relações estruturais recíprocas. Assim, abre-se espaço para a inovação, e para obras consideradas problemáticas com relação à classificação. Consideramos, da mesma forma, que os limites do gênero historiográfico não eram fixos, e que cada obra possui suas particularidades.

Segundo Hartog, o mesmo termo, historía, significou mercadorias diferentes ainda na Antiguidade Clássica ${ }^{5}$. A análise do proêmio das Histórias de Heródoto (aprox. 480-420 a.C.), tido como o primeiro historiador grego $^{6}$, pode ser, entretanto, um começo para estudarmos alguns limites, mesmo que não completamente estáticos, deste gênero de escrita:

\footnotetext{
${ }^{3}$ Genres and Readers (1994)

${ }^{4}$ Marincola $(1999,282)$.

${ }^{5}$ Hartog $(2001,12)$.

${ }^{6}$ Heródoto é chamado por Cícero de pai da história no diálogo De Legibus (1.5).
} 


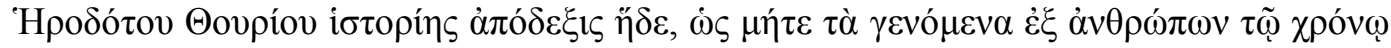

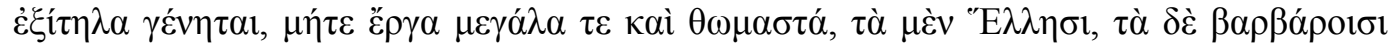

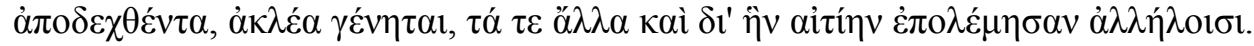

Esta é a exposição da investigação de Heródoto de Túrio para que nem os acontecimentos provocados pelos homens, com o tempo, sejam apagados, nem as obras grandes e admiráveis, trazidas à luz tanto pelos gregos quanto pelos bárbaros, se tornem sem fama e, no mais, investigação também da causa pela qual fizeram guerra uns contra os outros ${ }^{7}$.

O texto inicia-se com o nome do autor, Heródoto de Túrio (ou Halicarnasso em outras versões), impondo desde início um contraste com o gênero épico, no qual a voz principal é a das Musas. Heródoto estabelece-se como o autor das narrativas e responsável pelas investigações [historiê], diferentemente do aedo, que se identificava apenas como porta-voz, medium, de um saber que não era dele, mas divino. A marca de autoria, a reivindicação do estatuto de autor, não ficou, entretanto restrita à historiografia. Para Hartog, este egotismo é uma marca dos artistas, filósofos da natureza e médicos do séculos VI e V a.C. gregos ${ }^{8}$. A retórica do historiador antigo, diz Nicolai, constrói o caráter do historiador como de um narrador omnisciente, ou pelo menos competente e de grande autoridade ${ }^{9}$.

O termo historiê, forma jônica de historía, aparece logo em seguida ao nome do autor. O vocábulo, comumente traduzido por "pesquisa", "investigação", era utilizado pelos filósofos do século V. Segundo Knox, historeîn significava "fazer perguntas"; e em Heródoto, além de significar "questionar", e em alguns casos ela se transforma gradativamente de modo a significar "conhecer como resultado da indagação" 10 . Heródoto insere-se no modelo investigativo de seu tempo, e perpetua a ideia, já do séc. VI, de que o conhecimento pode ser alcançado pelo homem. A investigação de Heródoto debruça-se sobre as causas da guerra. Entretanto, os mitos também explicavam causas. Entretanto, Heródoto buscará, através de uma investigação sistemática, explicações humanas e seculares, e, em particular, políticas. ${ }^{11}$ Assim Darbo-Peschanski filia o surgimento da historiografia grega aos saberes da época:

"Greek history, even as imperfect as it is, would then be the conclusion of a progressive conquest, built on displacements and adaptations, of progress and decadence. It would be the daughter of "Ionian science", which was characterized by attention given to phenomena and by the wish to explain rationally the movement of nature which generates

\footnotetext{
${ }^{7}$ Hdt. Prólogo (Trad. de J. L. Brandão, apud Hartog (2001, 43).

${ }^{8}$ Cf. Hartog $(2001,17)$.

${ }^{9}$ Nicolai $(2007,14)$.

${ }^{10}$ Knox $(2002,104)$.

${ }^{11}$ Finley $(1989,24)$.
} 
the phenomena. Hence the so-called ethnographic or geographic dimensions that one can see not only in Anaximander but also in Hecateus or Herodotus. [...]. But if this is the case, two other positions have to be considered. In the first, history, in Herodotus' work, would be the result of the encounter of epic with Ionian historie, the one, through the Trojan War, giving form to the major "historical" intrigue of the conflict between the Greek west and Asiatic east, the other applying itself to the search for rational explanations of natural phenomena $[\ldots]^{12}$.

O termo historía pertence à família de histor, lexema que aparece nos textos homéricos com o sentido de "juiz", "árbitro", que tem a função de solucionar uma contenda. Na Ilíada 18. 497-508, está representada no escudo de Aquiles uma cena em que dois homens apelaram para um árbitro para resolver um desacordo por causa de uma dívida. Em 23. 482487, Ájax e Idomeneu não chegam a um acordo com relação a quem estava à frente na corrida organizada por Aquiles, e tomam Agamêmnon como árbitro. Não é possível saber a partir destes trechos se o hístor julga porque viu e testemunhou a ação, ou se o hístor fará uma investigação. A etimologia do termo seguramente para o sentido da visão; "historía, formada a partir do verbo historeîn, é derivada de histor (remetendo etimologicamente a ideîn, 'ver' e a (w)oida, 'saber') ${ }^{13}$. O hístor seria então aquele que sabe porque viu. Darbo-Peschanski ressalta que, seguindo a etimologia, a historiê seria o conhecimento obtido especificamente a partir da experiência visual. ${ }^{14}$

Mas Heródoto não falará apenas do que viu. Sua investigação pauta-se também naquilo que ouviu, e no raciocínio (gnômê). Heródoto assim diz em II.99:

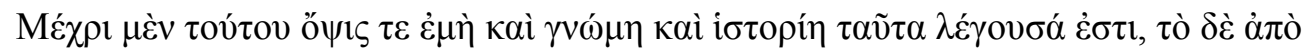

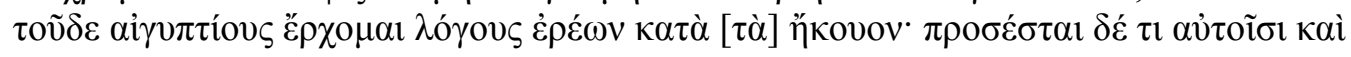
$\tau \tilde{\eta} \varsigma \dot{\varepsilon} \mu \tilde{\eta} \varsigma$ ö $\psi 10 \varsigma$.

Até aqui, falei segundo a minha observação (ópsis), reflexão (gnômê) e informação (historiê); mas, a partir de agora passarei a referir a tradição (lógos) egípcia, tal como a ouvi; acresce ainda um pouco do que vi. ${ }^{15}$

A investigação de Heródoto apoia-se não somente naquilo que viu com seus próprios olhos, mas também naquilo que ouviu. A tradição será relatada, mas nem sempre Heródoto

\footnotetext{
${ }^{12}$ Darbo-Peschanki (2007, 28-29).

${ }^{13}$ Hartog $(2001,51)$.

${ }^{14}$ Cf. Darbo-Peschanski (2007, 29): "The essential adaptation will have concerned the use of autopsy or personal visual experience, which is implicit in the very etymology of the word historie/a, directly derived from the noun history, itself derived from the * wid meaning 'see' and which also gives the verb oida, 'I know'. Just as history means 'the one who knows because he has seen' (Benvéniste 1948: 29, 32, 35, 51), so historiē would be, or would prepare one for, a knowledge founded more specifically on visual observation".

${ }^{15}$ Hdt. 2.99, Tradução de M. H. da Rocha Pereira apud "Introdução Geral”, in Heródoto (1994).
} 
terá elementos para julgar se a versão é digna de relato (“O meu dever é referir a tradição, mas de modo algum sou obrigado a acreditar nela. E que esta afirmação valha para toda a minha obra", 7.152). Mas em outros momentos, através do raciocínio, gnômê, Heródoto decide-se entre uma fonte ou outra, dando muitas vezes explicações de causas dos acontecimentos, entre outras reflexões. Este procedimento aproxima o autor do histor épico, a julgar por uma versão e outra ${ }^{16}$. Através da reflexão, Heródoto organiza os acontecimentos e os submete a uma narrativa racional dos movimentos da História ${ }^{17}$.

No proêmio de Heródoto está expressa a função de sua obra, a memória dos feitos dos homens, das grandes e maravilhosas empresas dos helenos e bárbaros e a razão (aitía) da guerra. A perpetuação da memória aproxima a historía da épica, mas as matérias diferenciamnas: a narrativa de Heródoto registra apenas os feitos humanos, de maneira que as ações e intervenções divinas não são focadas como na poesia épica. Para Heródoto, a historía tem por objetivo, portanto, criar um monumento, para que os feitos relatados não fiquem sem glória (akleâ).

Cerri \& Gentili ${ }^{18}$ afirmam que o historiador, neste contexto em que os homens se relacionavam até então com o passado, muitas vezes mítico, pela poesia, enfrenta dois grandes problemas: o primeiro, que já mencionamos acima, seria o problema da verdade e verossimilhança, ou seja, da verificação da informação obtida através da transmissão oral ou de documentos escritos. O segundo, a busca das causas para os eventos. Heródoto diz no Prefácio que busca os motivos, aitía, da guerra. O autor esquematiza e distingue para os eventos narrados muitas vezes próphasis, o pretexto, aitía, o motivo real, e arché, o momento inicial do evento político ou militar ${ }^{19}$. Com Tucídides, a crítica da tradição e tal estudo das causas se tornam objeto de uma rígida e sistemática teorização.

Primeiramente, a dimensão da escrita, com Tucídides, está em primeiro plano. Ele, no prefácio da Guerra do Peloponeso, utiliza o verbo syngráphein, registrar, para dar nome à sua atividade, no lugar de historeîn. Em 1.22 Tucídides afirma que seu escrito não parecerá uma

\footnotetext{
${ }^{16}$ Cf. Darbo-Peschanski $(2007,35)$ : "Historia is a first judgment (or group of judgments) made about the phenomena by a first authority. I will itself be the object of a new judgement, this time a decisive one, emanating from a second authority. It thus constitutes an operation necessary but not autonomous, wich leads to a ruling on what is just or real, and sometimes on both when reality is justice, as in Herodotus."

${ }^{17}$ Cf. Darbo-Peschansky $(2007,30)$ :"It would also be born from the fact that the story conforms to the rules of factual verification and that it analyzes the causes in order to deliver a rational and non-fictional account (apodexis) of the movements of history. Narrative reconfiguration, a method guaranteeing conformity to the facts, rationality, design of truth - such are the components of the concept that one seeks to recognize in Herodotus' work".

${ }^{18}$ Cerri \& Gentili $(1988,9)$.

${ }^{19}$ Cf. Cerri \& Gentili $(1988,11)$.
} 
narrativa oral apenas prazerosa, mas que será suficiente para o leitor que quiser ter uma visão clara dos eventos que aconteceram e daqueles que acontecerão de maneira parecida, dentro da probabilidade humana. Há também uma clara ruptura com Heródoto quando Tucídides propõe, nos primeiros parágrafos de sua obra, de que só pode haver história verdadeira do presente, uma vez que só é confiável aquilo que é testemunhado pelos olhos (filtrado pela crítica dos testemunhos, autopsía), pois aquilo que é ouvido pode ser distorcido pela memória com o passar dos anos ${ }^{20}$. Políbio também promove a visão como o sentido mais verdadeiro, e propõe que o historiador deveria ser um homem de ações, envolvido na política e que deveria experimentar diretamente as ações, e o compara a Ulisses ${ }^{21}$. O tempo presente será apresentado por Tucídides (455-404 a.C., aprox.) como um exemplo para a posteridade. "Tucídides", diz Hartog,

escolhendo colocar por escrito uma guerra, aquela que ele sabia de imediato dever ser 'a maior' de todas, apresenta sua narrativa como uma 'aquisição para sempre'. Do kléos ao ktêma, o deslocamento é sensível. Pela postura que adota, o historiador entende que sua história se dirige aos homens do futuro, transmitindo-lhes, com essa narrativa que ele efetivamente chamou de para sempre A Guerra do Peloponeso, um instrumento de inteligibilidade dos presentes por vir. Pois levando-se em conta o que são os homens, outras crises análogas não deixarão de irromper no futuro. É essa permanência da natureza humana que funda, para Tucídides, a exemplaridade deste conflito. ${ }^{22}$

O registro feito por Tucídides faz do presente um exemplo, principalmente político e militar, para o futuro. Tucídides não se identifica como historiador, mas seu método de investigação é também próprio do século quinto grego. Segundo Knox, o verbo skopeîn é um dos favoritos de Tucídides para referir-se à sua atividade. Ele significa "examinar", e descreve um escrutínio calculador e crítico, que avalia e tira conclusões a partir de evidências ${ }^{23}$.

E suma, segundo Momigliano ${ }^{24}$, três elementos contribuíram para a noção de história no século quinto grego: a dúvida sobre os mitos e genealogias tradicionais, a curiosidade sobre terras e instituições estrangeiras, interesse pela variedade de tipos humanos. Mas o que dá à pesquisa historiográfica a maturidade e sabor distintivo é a subordinação da genealogia e dos relatos de viagens à narração crítica de eventos políticos e militares, mais especificamente eventos políticos e militares gregos recentes. E tais eventos são submetidos à crítica das fontes e sistematizados e interpretados por uma noção de causalidade.

\footnotetext{
${ }^{20}$ Cf. Th., 1.2-13.

${ }^{21}$ Plb. XII. 27-28.

${ }^{22}$ Hartog $(2001,98)$.

${ }^{23} \operatorname{Knox}(2002,105)$.

${ }^{24}$ Momigliano $(1993,101)$.
} 
Heródoto e Tucídides, ambos do século quinto, compartilham do mesmo objeto. A história para eles tem por objeto res gestae; suas histórias relatam essencialmente eventos políticos e militares, e também material etnográfico. Fornara afirma que a qualidade compartilhada por todos escritos considerados históricos na Antiguidade, a saber, monografias, histórias contemporâneas, histórias universais (e ele exclui a biografia pois a considera uma forma ética e não histórica), era a dedicação direta à descrição de res gestae, ações dos homens na política, diplomacia e na guerra, seja no passado distante ou recentes ${ }^{25}$. Fornara, entretanto, utiliza a esquematização realizada muito anteriormente por Felix Jacoby (Über die Entwicklung der griechischen Historiographie und den Plan einer neuen Sammlung der griechischen Historikerfragmente, 1909), que dividia as obras historiográficas gregas em cinco subgêneros (numa visão evolucionista): mitografia ou genealogia, etnografia, cronografia, história contemporânea (Zeitgeschichte) e história local. Mas Fornara, entretanto, não considerava a cronografia e a etnografia como história, por não mimetizarem res gestae e não apresentarem causas e relações entre os eventos.

John Marincola ${ }^{26}$, entretanto, argumenta que esta visão de Fornara, a tendência moderna de considerar os feitos da guerra como a matéria própria da história, resulta de um olhar sobre os historiadores canônicos supérstites, tidos como principais. Marincola demonstra que há muitas evidências de que outros historiadores antigos tinham por objetos não apenas feitos políticos e militares, mas também eventos e atividades culturais, a vida religiosa de um estado e povo, os costumes e até as vidas e caracteres dos líderes do estado (importante quando um estado é governado por um único homem ou mulher).

Do século quarto, restou-nos parte da obra de Xenofonte, que parece ter escritos obras que ultrapassaram a matéria política e militar. No início do século, Xenofonte escreve Hellenica, colocando-se como continuador de Tucídides no que diz respeito à cronologia, pois Xenofonte inicia do ponto em que Tucídides parou, mas inexistem em sua obra explicações metodológicas. Xenofonte era também filósofo, polígrafo, e escreveu diversas obras de variados gêneros, como a Ciropedia, uma novela biográfica, que trataremos no capítulo sobre os antecedentes da biografia.

Há indicativos de que as obras historiográficas de Teopômpo e Éforo, do século quarto, debruçavam-se sobre questões além de eventos político-militares. Ambos eram discípulos de Isócrates (segundo testemunho de Cícero), logógrafo, e deveriam, portanto isso,

\footnotetext{
${ }^{25}$ Fornara $(1983,3)$.

${ }^{26}$ Marincola (1999, 306).
} 
ter forte formação em Retórica. Dionísio de Halicarnaso, em Carta a Pompeu Gemino, assim fala sobre a obra de Teopômpo:

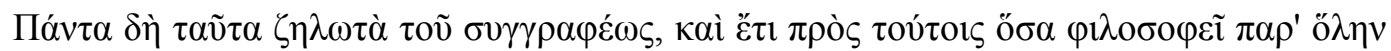

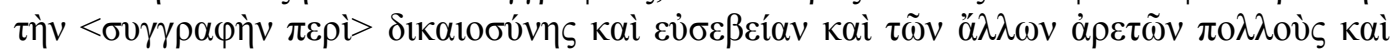

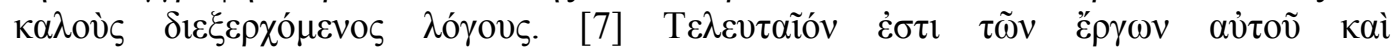

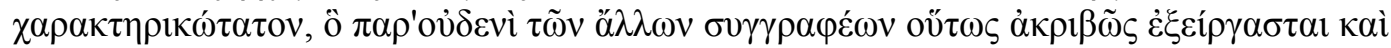

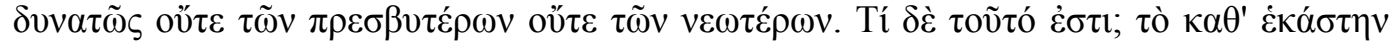

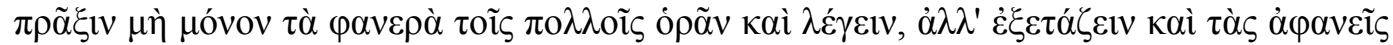

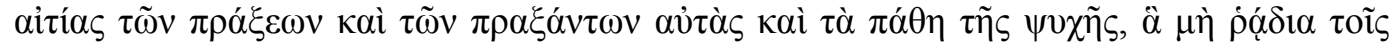

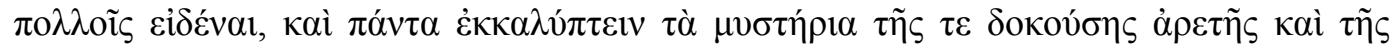

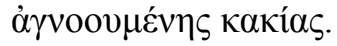

Todas as qualidades desse historiador são invejáveis e, além disso, também o quanto filosofa em sua <narrativa>, consagrando muitas passagens à justiça, à piedade e às outras virtudes. [7] Há uma última qualidade de suas obras, a mais característica - a qual não é praticada por nenhum outro historiador com tanta exatidão e vigor, nem entre os antigos, nem dentre os modernos. Qual é ela? É ver e dizer, para cada ação, não somente o visível para a maioria das pessoas, mas examinar a fundo as causas invisíveis as ações, as motivações de seus autores e as afecções da alma ( o que não é fácil de ser conhecido pela maioria), bem como desvelar todos os mistérios da virtude presumida e do vício desconhecido ${ }^{27}$.

Vemos a partir de tal testemunho que a história de Teopômpo deveria caracterizar psicologicamente as personagens históricas, descrever costumes, e organizar a narrativa filosófica e moralmente. Da mesma maneira a historiografia de Éforo não devia ater-se somente ao relato objetivo de eventos militares e políticos. Políbio, já no século segundo, com quem ressurge o mesmo rigor e objetividade na busca pelos fatos e pelas causas que preceituara Tucídides, na introdução ao livro 9, ataca a historiografia isocrática de Éforo, rejeitando a abordagem etnográfica e antropológica que ele fazia dos mitos sobre fundações de cidades e colônias. A História para Políbio deve ser estritamente pragmática, limita-se a eventos políticos, excluindo discussões etnográficas, relatos de relacionamentos, costumes, e digressões geográficas, comuns na historiografia isocrática, que buscava também deleitar o leitor. Políbio não deseja ser somente prazeroso, mas também ser útil ${ }^{28}$. Entretanto, como sabemos, o livro 2 das Histórias de Heródoto trata da geografia e costumes do Egito, matéria, portanto, etnográfica.

Assim, a questão dos limites do gênero parece ter sido controversa já na Antiguidade. Talvez possa ter havido em alguns momentos uma noção predominante da história como história política, tal como tentou preceituar Políbio, ou como demonstra a própria obra de

\footnotetext{
${ }^{27}$ D. H., Pomp. 6.6-7. Tradução de Jacyntho Lins Brandão, apud Hartog $(2001,97)$.

${ }^{28}$ Cf. Cerri \& Gentili $(1988,27)$.
} 
Tucídides. Isso parece se confirmar nas palavras de alguns autores antigos diferenciando história e biografia. Mas deixaremos o tema para o capítulo sobre a biografia.

Outra questão que apresenta algumas controvérsias entre os historiadores é a ideia de que a história tem uma função didática; se suas explicações das causas podem ou não compor um sistema dedutivo, ou seja, se o estudo carrega em si leis universais.

A partir da leitura do prologo das Histórias, podemos depreender que, para Políbio, seu escrito, a história pragmática, tinha como importante função levar o leitor a entender mais claramente como Roma chegou ao poderio do mundo, sendo que tal conhecimento seria proveitoso para quem deseja instruir-se (1.1.5). Também no Prefácio, Políbio afirma que muitos historiadores já haviam afirmado, com certa obviedade, que o aprendizado decorrente da historia é a educação e treinamento para atividades politicas, e que a recordação dos revertérios alheios ensina a suportar as mudanças da fortuna (1.1.2-3) ${ }^{29}$. O entendimento da história como magistra de certa maneira já estava presente na concepção de Tucídides de que sua obra seria útil e válida também para o futuro. ${ }^{30}$

Mas é na cultura romana, na qual existia o culto aos antepassados, que a história será mais frequentemente entendida como exemplar, fornecedora de paradigmas políticos e morais. Salústio justifica a utilidade da sua escrita lembrando a prática romana da contemplação de imagens dos ancestrais:

Nam saepe ego audiui Q. Maxumum, P. Scipionem, preaterea ciuitatis nostrae praeclaros uiros solitos ita dicere, cum maiorum imagines intuerentur, uehementissume sibi animum ad uirtutem accendi. Scilicet non ceram illam neque figuram tantam uim in sese habere, sed memoria rerum gestarum eam flammam egregiis uiris in pectore crescere neque prius sedari, quam uirtus eorum famam atque gloriam adaequauerit.

Pois sempre ouvi que Q. Máximo e P. Cipião, e também outros homens ilustres da nossa cidade, costumam dizer que, ao ver as imagens dos ancestrais, o ânimo se acendia fortemente para a virtude. Certamente, nem aquela cera e nem a figura tinham em si tamanha força, mas a memória dos feitos realizados pelos grandes homens faz crescer no peito uma chama, que não se apaga antes que a virtude adquira a mesma fama e glória ${ }^{31}$.

\footnotetext{
${ }^{29}$ Concordaria Políbio plenamente com esta afirmação?. Difícil de formular uma resposta simples para esta questão, pois a opinião de Políbio sobre a historia exemplar á não só complexa quanto deve variar ao longo dos livros, tendo em vista que o historiador passou muitos anos escrevendo sua obra. Em alguns trechos, como no 3.31.8-13, o autor parece questionar a ideia da apenas como uma fornecedora de exemplos a serem imitados. O historiador aponta que o que torna a historia útil, o que produz alguma instrução (matema), não é a narrativa dos eventos (apenas uma exercício estéril e prazeroso), mas sim a discussão da razão, motivos e meios por quais um feito foi realizado, e se este ocorreu de maneira conforme as expectativas. Assim, Políbio afasta-se da ideia da historia como uma manual de ações e comportamentos para serem diretamente imitados ou evitados; parece-nos que concepção pedagógica do historiador está ligada ao estudo das causas.

30 Nicolai $(2007,16)$. "Historiography, heir of epic poetry, will retain this goal of preserving memory (cf. Herodotus's preface) and also the goal of suggesting itself as a repertoire of dynamics and behaviors, in other word paradigms (especially, with Thucydides, politico-military paradigms: see his famous formulation, 1.22.4)"

${ }^{31}$ Sal. Jug. 4.5-6. (Ed. Paris, 1924). Tradução minha.
} 
A contemplação de imagens dos antepassados, moldadas a partir de máscaras mortuárias, e a recordação dos seus feitos cumpriam um importante papel didático nos rituais fúnebres romanos, conforme podemos observar na descrição do ritual feita por Políbio, em Histórias 6. 53-54. A memória do homem virtuoso era capaz de despertar a imitação:

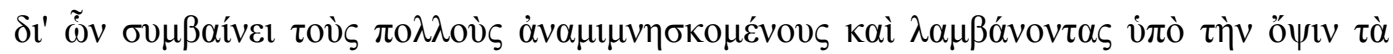

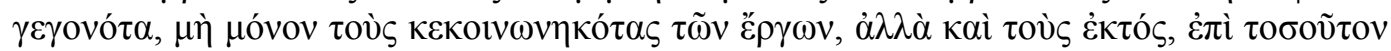

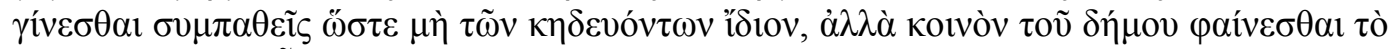

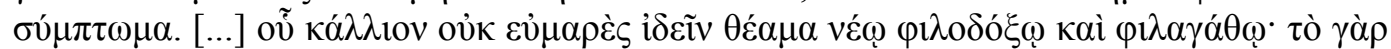

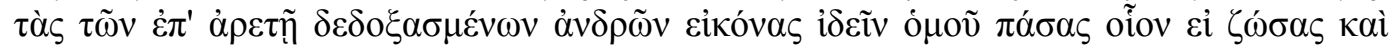

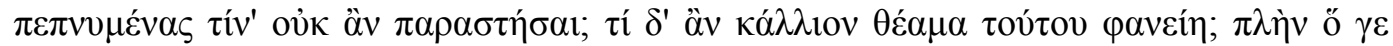

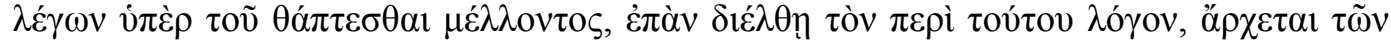

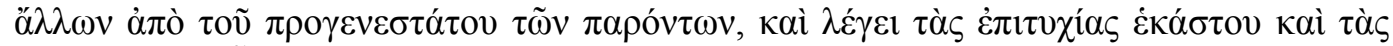

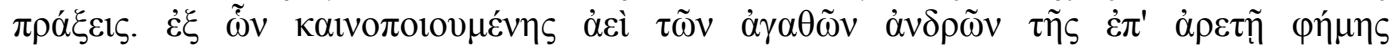

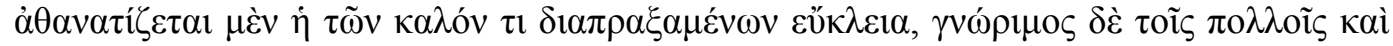

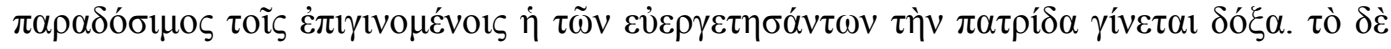

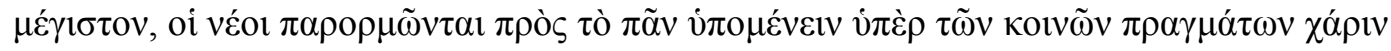

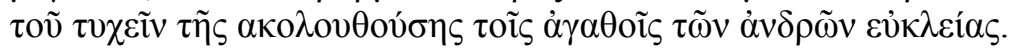

Consequentemente toda a multidão, e não apenas quem teve alguma participação nesses feitos, mas também quem não teve, quando os fatos são relembrados e postos diante de seus olhos comove-se e é levada a tal estado e empatia que a perda parece não se limitar somente a quem chora o morto e ser extensiva a todo o povo. [...] Não seria fácil imaginar um espetáculo mais nobilitante e edificante para um jovem que aspire à fama e à excelência. De fato, quem não se sentiria estimulado pela visão das imagens de homens famosos por suas qualidades excepcionais, todos reunidos como se estivessem vivos e respirando? Poderia haver um espetáculo cívico mais belo que esse? 54. Além disso, o orador incumbido de falar sobre o homem prestes a ser enterrado, após pronunciar-se a respeito do defunto evoca os sucessos e feitos dos outros defuntos cujas imagens também estão presentes, começando pelo mais antigo. Por esse meio, por essa renovação constante das referências às qualidades dos homens ilustres, a fama dos autores de feitos nobilitantes é imortalizada, e ao mesmo tempo o mérito de quem prestou bons serviços à pátria chega ao conhecimento do povo, constituindo um legado para as gerações futuras. O resultado mais importante, porém, é que os jovens são estimulados assim a suportar qualquer provação pelo bem da coletividade, na esperança de obterem a glória que acompanha os homens valorosos ${ }^{32}$.

A história, proporcionando da mesma forma o retrato dos antepassados romanos, e despertando a memória dos feitos, cumpre, assim, a mesma função que os retratos de cera dos antepassados, a de estimular a imitação das virtudes, ou a não imitação dos vícios. Políbio descreve o ritual como um espetáculo em que o jovem vê o antepassado como se estivesse vivo, e da mesma forma a história pode ser entendida, pois expõe os feitos dos homens diante dos olhos.

${ }^{32}$ Plb. 6.53 -54 (Trad. De Mário da Gama Cury). 
Salústio compõe também retratos morais de caráter didático, mas Hartog destaca, entretanto, que o a visão de Salústio sobre seu presente é tão pessimista que ela não acredita que os homens de seu tempo possam emular os antepassados, evidenciando assim a decadência moral que vive Roma ${ }^{33}$. Veremos que Tito Lívio, em seu Prefácio, afirma que sua obra fornecerá exemplos, lições, do que evitar ou imitar para si o para a República.

Segundo Nicolai, todos os paradigmas da historiografia antiga grega e romana possuíam fim paidêutico e um fim em algum sentido político: formar uma classe governante, oferecendo instrumentos analíticos e modelos de comportamento, apresentar grandes personalidades, virtuosas ou viciosas, como exemplos, bem como os parâmetros de avaliação moral (como Teopômpo, Tácito e a tradição biográfica); ou construir a memória e identidade coletiva, como as narrativas de fundação ${ }^{34}$. Em algumas obras este caráter pedagógico está em maior evidência, e em outras menos. Mas seria realmente possível fornecer exemplos de comportamento para o futuro? Em outras palavras, uma ação ou comportamento produz necessariamente sempre o mesmo efeito? Do particular pode se deduzir algo universal? Aristóteles parece já ter tocado nesta questão ao diferenciar poesia e história e afirmar que a última dedica-se ao particular:

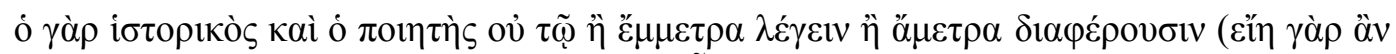

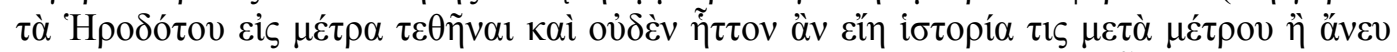

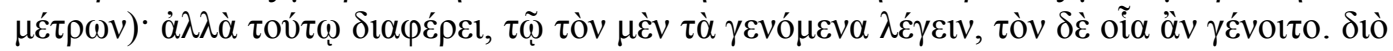

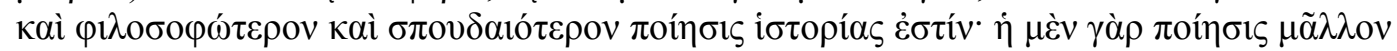

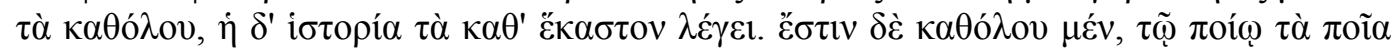

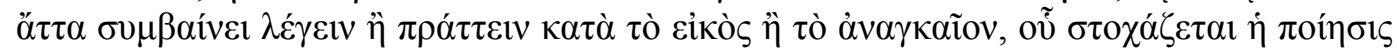

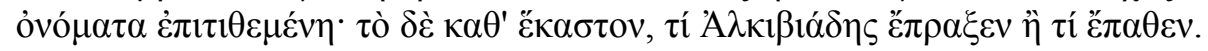

Com efeito, não diferem o historiador e o poeta por escreverem verso ou prosa (pois que bem poderiam ser postos em verso as obras de Heródoto, e nem por isso deixariam de ser história, se fossem em verso o que eram em prosa) - diferem, sim, em que diz um as coisas que sucederam, e outro as que poderiam suceder. Por isso a poesia é algo de mais filosófico e mais sério do que a história, pois refere aquela principalmente o universal, e esta o particular. Por "referir-se ao universal" entendo eu atribuir a um indivíduo de determinada natureza pensamentos e ações que, por liame de necessidade e verossimilhança, convém a tal natureza; e ao universal, assim entendido, visa a poesia, ainda que dê nomes às suas personagens; particular, pelo contrário, é o que fez Alcibíades ou o que lhe aconteceu ${ }^{35}$.

Da definição de Aristóteles entende-se que a história dedica-se ao particular e, portanto, seria menos filosófica que a poesia, e não poderia ser assim uma ciência, pois só há

\footnotetext{
${ }^{33}$ Cf. Hartog $(2001,184)$.

${ }^{34}$ Cf. Nicolai $(2007,14)$.

${ }^{35}$ Arist. Po. 1451B (Trad. Eudoro de Souza).
} 
ciência do geral, não pode haver uma ciência baseada em particularidades. Para Aristóteles, o objeto da história são os feitos e acontecimentos de Alcibíades, matéria particular, portanto; o que lhe ocorreu poderia ter se dado de outra maneira. Rutherford, entretanto, afirma que a distinção aristotélica foi vista como uma tendência, e não como uma distinção estanque:

"The passage has been much discussed. It evidently implies that the lots and narratives of poetry exclude the clutter of detail and incidentals which complicate those of history; but we may note that this is described as a tendency ("speaks more of..."), for of course poetry cannot do without all particulars, and the historian must select, sift, and shape his subject matter in order to provide any kind of analysis and generalization. Insofar as he does so he is acting as a poet might; insofar as he does so with a view to creating dramatic and emotionally intense effects, he may be said to resemble the tragedian in some degree. This tendency was detected by ancient readers in several of ancient historians, above all in the work of Thucydides (e. g., D. Hal. Thuc. 15)"36.

O historiador Carlo Ginzburg defende que Aristóteles nesta passagem aludia à historiê de Heródoto, historiador criticado também na Retórica 1409a por seu estilo, e não à Tucídides, cujo trabalho era mais arqueológico, e baseava suas conclusões em provas e entimemas $^{37}$. Tucídides, entretanto, jamais emprega o termo historía em sua obra; ele define seu trabalho com o verbo syngráphein. Mas ainda que Aristóteles refira-se a Heródoto, a contradição persiste, pois Heródoto também busca elevar a sua investigação ao caráter universal e científico, ao buscar encontrar certos padrões nas ações e comportamentos humanos, e ao tentar extrair do particular regras gerais. Um exemplo deste tipo de generalização pode ser encontrado logo no início das Histórias, em 4.4, quando Heródoto amplia sua análise sobre o declínio ou aumento das cidades, tratando de muitas cidades, e associa isso à inconstância da felicidade humana ${ }^{38}$.

Embora a história trate de particulares, os historiadores não poucas vezes buscavam generalizações e encontrar explicações semelhantes para determinados acontecimentos; e, consequentemente, fornecer lições atemporais. Veyne nos adverte, entretanto, que as leis que o historiador parece estabelecer com a narrativa história são na verdade truísmos, as causalidades apontadas pelo historiador são sempre causalidades vividas, e não científicas ${ }^{39}$. Segundo o autor, a história é

\footnotetext{
${ }^{36}$ Rutherford $(2007,505)$.

${ }^{37}$ Cf. Ginzburg $(2002,56)$. D. M Pippidi, em paper publicado em Mélanges J. Marouzeau - Paris 19848 pp.483490, também defende que Aristóteles não inclui Tucídides em sua condenação dos historiadores.)

${ }^{38}$ Cf. Hdt. 4.4.

${ }^{39}$ Cf. Veyne (1995, 73-88).
} 
definitivamente, narrativa e limita-se contar o que Alcebíades fez e o que lhe aconteceu. Longe de desembocar em uma ciência ou em uma tipologia, a história não cessa de confirmar que o homem é matéria variável sobre a qual não se pode fazer um julgamento fixo; continua, hoje, a não saber mais do que jamais o soube, sobe como se articulam o econômico e o social, e é ainda mais incapaz do que no tempo de Montesquieu de afirmar que, dado o acontecimento A, B se produzir" ${ }^{40}$.

Impossível depreendermos leis naturais da matéria histórica tal como as leis naturais da física. Os acontecimentos são sempre particulares, que poderiam ter ocorrido de outra maneira. Entretanto, os historiadores antigos, ao organizar sua narrativa e apontar as causas, parecem buscar universalidades, ou ao menos, tendências, como parece propor Max Weber (1864-1920) em La Cité, estabelecendo uma rede de variantes para os eventos: determinado tipo de acontecimento favorece um outro ${ }^{41}$.

Políbio afirma que a história é útil para algum aprendizado (embora isso esteja mais ligado para ele ao estudo das causas que ao fornecimento de modelo), ao diferenciá-la da Tragédia:

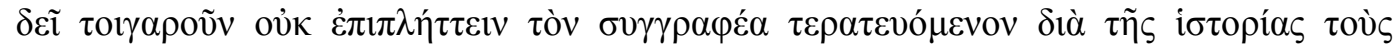

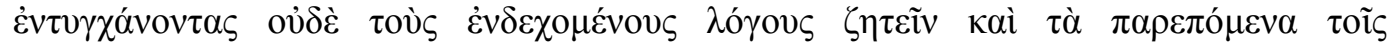

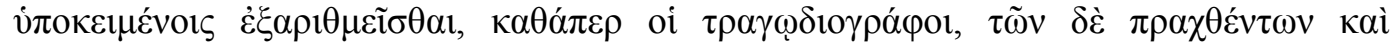

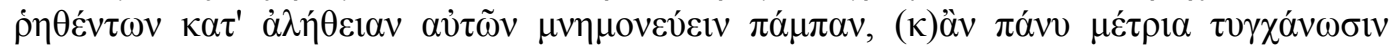

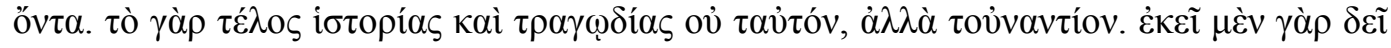

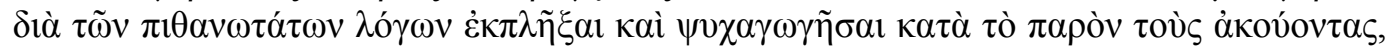

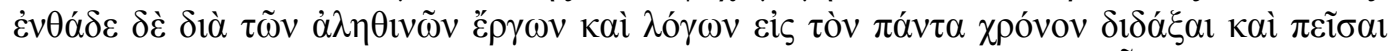

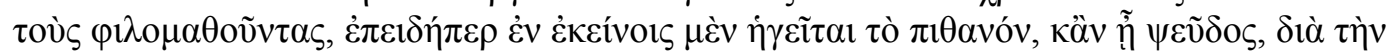

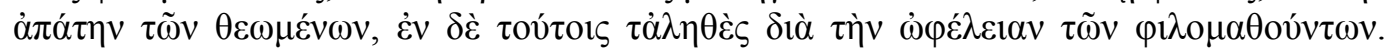

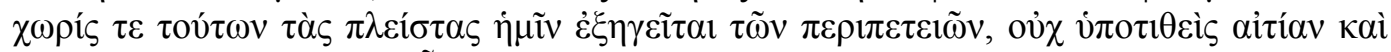

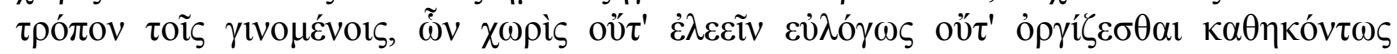

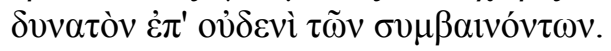

É preciso que o historiador não comova os leitores com exageros espalhados ao longo da história, nem que procure discursos ocasionais ou acrescente sequências aos relatos, como os tragediógrafos, mas que apenas relembre coisas ditas e feitas conforme a verdade, mesmo que sejam muito triviais. Pois a finalidade da história não é a mesma da tragédia, mas a oposta. É preciso que esta emocione e seduza os leitores no presente por meio de discursos os mais plausíveis, e que aquela ensine e persuada os amantes do aprendizado a qualquer tempo com obras e discursos verdadeiros; muito embora na primeira predomine o plausível, mesmo que falso, devido à ilusão dos espectadores, na segunda o faz o verdadeiro, em vista do proveito dos amantes do aprendizado. Além disso, narra-nos muitas peripécias não supondo causa ou variação nos acontecimentos, sem os quais não é possível apiedar-se racionalmente nem encolerizar-se convenientemente com nenhum dos acontecimentos $^{42}$.

\footnotetext{
${ }^{40}$ Veyne $(1995,114)$

${ }^{41}$ Veyne $(1995,147-8)$

${ }^{42}$ Plb. 2.56. 10-13 (Trad. de B. B Sebastiani, apud Sebastiani (2007, 74).
} 
A história para Políbio é mais útil que a poesia, pois se dedica ao aprendizado, enquanto a poesia visa à ilusão. Neste trecho, Políbio ataca seu predecessor Filarco por escrever um tipo de historiografia à maneira das tragédias, centrada na exibição do patético, que serviria apenas para comover, e não para o ensino ${ }^{43}$. A história para Políbio, ao contrário da poesia, gera um proveito (ôphéleian), pois ela permite, através da exposição das causas, 'apiedar-se racionalmente' e 'encolerizar-se convenientemente' com os acontecimentos. Segundo Sebastiani, tragédia e história se assemelhariam quanto à emoção que produzem mas na história estas são mais racionais e apropriadas devido à cadeia causal, inexistente na tragédia ${ }^{44}$. Para Políbio, claramente, a função instrutiva da história está ligada ao estudo das causas dos acontecimentos, e não propriamente ao fornecimento de exempla diretos de moral e comportamento.

A história é magistra então no sentido de que, ao estudar as causas, ensina que circunstâncias favorecem a vitória ou um fracasso, ou propiciam uma revolta etc. Ela pode fornecer paradigmas morais, como nos retratos. Mas devemos lembrar que, ao estabelecer um nexo causal, o historiador está sempre fazendo um recorte, uma abstração parcial a partir dos fatos. A explicação privilegia sempre um determinado aspecto. A narrativa de Tito Lívio, como veremos, apresenta frequentemente causalidades morais, criando, artificialmente, é claro, um sistema, em alguma medida, dedutivo, em que há tendência para o fracasso militar quando há afrouxamento das virtudes do comandante, por exemplo. Este processo envolve uma organização da narrativa num nexo causal, e isto é também um procedimento literário. Antes de tratarmos da relação entre história, poesia e retórica, falemos um pouco mais do gênero entre os romanos.

Desvendar o início da Historiografia latina não é tarefa fácil, pois muito pouco dos textos dos pioneiros Fábio Pictor e Catão chegou até nós. Pouquíssimo sabemos acerca dos historiadores anteriores a Salústio. Cícero, no diálogo De Oratore, 2.53, faz a personagem Antônio falar acerca dos historiadores latinos anteriores ao tempo ficcional do diálogo, elogiando-os por sua eloquência e igualdade para com os historiadores gregos. Marincola ${ }^{45}$ afirma que esta caracterização provavelmente soava como falsa, pois os historiadores latinos até então não teriam superado os gregos. Mas o estudioso defende que neste trecho Cícero propõe um ideal do historiador, preceituando qualidades em sua maioria estilísticas.

\footnotetext{
${ }^{43}$ Cf. Walbank (1985) e Sebastiani (2007).

${ }^{44}$ Sebastiani $(2007,75)$.

${ }^{45}$ Marincola $(2007,7)$.
} 
Segundo Fornara ${ }^{46}$, Fábio Pictor, Lúcio Cíncio Alimento, Gaio Acílio Póstumo Albino e Catão, o Velho, datados da Segunda Guerra Púnica até 150 a.c., compuseram suas histórias adotando o padrão grego de historiografia, e não ainda a forma que será a principal característica da historiografia latina: o padrão analístico. Cássio Hemina, que escreveu na segunda metade do século segundo, teria sido o primeiro dos analistas ${ }^{47}$. Mas outros historiadores, como Hans Beck e Marincola, discordam e acreditam que todos estes autores já seguiam um padrão analístico; Marincola, inclusive, questiona se esta distinção entre historiadores e analistas teria realmente existido naquela época ${ }^{48}$.

Os historiadores analistas seguiam o padrão dos annales maximi, crônicas escritas pelos pontifices maximi, que a cada ano anotavam em uma tábua os nomes dos cônsules, dos magistrados e os principais eventos ocorridos na cidade ou em campanha. O monumental poema épico de Quinto Ênio (236-169 a.c.), intitulado Annales, organizou-se ano a ano, criando comentários aos registros dos pontífices. Este tipo de escrita de anotações oficiais, listas de eventos, horografia, como denomina Fornara, também existia na Grécia, e não seria nunca confundido com a história ${ }^{49}$. Em Roma, a forma analística se impôs aos escritores de história, que consideraram a estrutura conveniente aos seus propósitos. O relato das res gestae, a história pragmática, subordina-se ao sistema de relato ano a ano. Hans Beck reconhece assim a influencia da "analística" como a principal característica da Historiografia Romana:

No matter how frequently the early Roman historians included the annalistic features in their works (e.g., Coelius hardly any, Piso quite significantly, Valerius Antias excessively), and no matter how intensively the historiographical tradition of the republic in general was committed to year-by-year structure, the mere principle of presenting history as some sort of commentary on the time-honored tabulae for the high priest became the most important characteristic of Roman historiography. The tendency of verifying histories via annalistic mode and means signaled continuity, security, and institutional stability from the beginnings of Rome to the present. Annalistic structure thus provided an intellectual frame for a peculiar perception of the past, in which the historiographical tradition amalgamated with others elements of Roman cultural memory, especially the self-identification with the exempla virtutis and the commitment to mos

\footnotetext{
${ }^{46}$ Fornara $(1983,25)$.

${ }^{47}$ Cf. Fornara $(1983,25)$.

${ }^{48}$ Marincola (1999, 289-90).

49 Marincola $(2007,8)$, entretanto, afirma que provavelmente não havia a distinção entre historiador e analista na Antiguidade: "First, such a distinction cannot be found in the ancient authors, where 'scriptor annalium' or the like serve as a designation for all writers of history. Second, the Latin word annals means both history (in the aggregate and objective sense) and particular history (the literary representation of events). Third, citations of Roman historians refer indiscriminately to annales and historia, which suggests not only that the writers themselves did not assign any such title as Annales to their works, but also that there cannot have been a recognized subgenre of annales.
} 
maiorum, the 'customs of our ancestors'. Livy's 142 books $A b$ urbe condita are the most towering - and the final - monument of this approach. But even then it was by no means unchallenged. As ever, so in the age of Augustus, historiography was determined by conflicting and competitive approaches, just as the concepts of writing history had so often been altered since Fabius Pictor and Cato had first embarked on this exciting journey"s0.

A presença do material fornecido pelas anotações dos pontífices confere à historiografia uma nova fonte documental, que era considerada confiável no que se refere às datações de eventos políticos. O estudioso ressalta também que os anais estavam amalgamados a elementos da memória cultural romana, e assim historiografia une-se ainda mais à percepção de exemplos virtuosos do passado e costumes dos antepassados.

Fornara $^{51}$ ressalta que até Fânio e Asélio, historiadores da Revolução Graca que substituíram o interesse antiquariano pela historiografia política, possuíam estrutura analística. Salústio (nas Histórias) e Lívio mantiveram, embora não com a mesma rigidez, a técnica seletiva analística destes autores em suas obras. A forma dos anais se torna a maneira ortodoxa de escrever a história, e segundo Fornara, para Tito Lívio, a forma mostrou o veículo perfeito para sua multifacetada abordagem do passado romano.

Salústio e Tito Lívio são considerados os grandes historiadores do período republicano tardio. Para Quintiliano (Quint. 10.1.101; cf. 2.5.19), Salústio, de quem apenas nos restaram monografias históricas, é considerado o Tucídides romano, e Lívio o Heródoto romano, já que Salústio dedicou-se aos males do presente em suas duas monografias históricas: a conjuração de Catilina e a guerra de Jugurta. Embora Salústio dedique-se ao tempo presente e, em tom pessimista, escreva sobre as corrupções de seu tempo e Lívio afirme, em seu Prefácio, que terá por objeto o tempo passado, justamente para fugir dos males do presente, ambos apresentam semelhanças. Segundo Levene, ${ }^{52}$ os dois compartilham do entendimento história romana em termos de um declínio moral resultante das conquistas militares, em termos do influxo de riquezas e abandono de motivos para rigidez moral; ambos estão interessados em figuras ambivalentes; ambos, em algum momento, são cautelosos ao focar os conflitos sociais como causas primárias para muitos eventos políticos.

Como vimos, Heródoto, Tucídides e Políbio, de alguma maneira, atentaram para alguns critérios que guiariam a investigação da verdade, como, por exemplo, a visão e vivencia dos acontecimentos narrados, e experiência militar e a correta interrogação de testemunhas. A experiência e a percepção, às vezes de testemunhas, mas sempre investigada e

\footnotetext{
${ }^{50}$ Beck (2007, 265).

${ }^{51}$ Fornara $(1983,23-28)$.

52 Levene $(2007,286)$
} 
analisada pelo conhecimento do historiador que conhecia empiricamente o ambiente político e militar descrito, eram critérios para a escrita veraz. Tito Lívio, entretanto, trata de um passado que não vivenciara e, além disso, não possuía conhecimento empírico político-militar. Ao longo da narrativa, Tito Lívio faz apenas uma investigação, comparação e questionamento de suas fontes, escritores anteriores aos quais teve acesso. A matéria de Lívio é, nas primeiras décadas, um passado muito distante de si. Mas, segundo Sebastiani, "outro instrumento teórico permitiria que o historiador se libertasse dos laços que o prendiam ao presente" ${ }^{53}$, a Retórica. O conhecimento da Retórica, segundo Cícero, é requisito para o historiador. E em Lívio a retórica ganha maior importância que nos historiadores gregos. Conforme afirmou Grénier, o verossímil é para Tito Lívio, “como convém a um fervoroso devoto da Retórica, a medida do verdadeiro" ${ }^{54}$.

Segundo Sebastiani, no século primeiro em Roma, o discurso da história passa a ser regulado e institucionalizado pela retórica:

um indivíduo conhecedor das práticas retóricas podia escrever tanto sobre o presente experienciado quanto sobre o passado cuja maior ou menor escassez de vestígios condicionava a maior ou menor veracidade do relato. $\mathrm{O}$ método de trabalho do historiador não mais se centra no estabelecimento de uma verdade que corresponda diretamente à tradução literária de sua apreensão pessoal da realidade, mas à ueritas entendida em termos de fides, credibilidade emprestada à narrativa. Enquanto construção retórica, a verdade se situa no plano da plausibilidade que o leitor encontra no relato, e não necessariamente na exata correspondência entre realidade e discurso. Conjugado com a experiência pessoal em Salústio, o conhecimento retórico é erigido por Tito Lívio como o único fator de legitimidade de sua obra. Aprofundando as possibilidades narrativas já sinalizadas pelo primeiro, Tito Lívio escreve sobre o passado romano mais recuado sem jamais haver ocupado um cargo político ou militar, tendo dedicado toda sua maturidade e velhice à redação de seu trabalho.

Essa ideia foi também defendida por Cícero, para quem a história é tarefa do orador (De orat. II.62), e deve seguir as regras do gênero demonstrativo (De. Orat. 2.12.54). Em sua famosa carta Luceio, Cícero, ao aconselhar o interlocutor sobre a escrita de uma monografia acerca do consulado ciceroniano, preceitua que a história deve ser ornada: “Assim, peço-te e peço-te que as ornamentes com mais veemência até talvez que sintas, e que nisto negligencies as leis da história [...]" ${ }^{\prime 55}$ (Ad. Fam. 5.12.3). Na mesma carta Cícero ainda recomenda que Luceio deve explicar os acontecimentos, indicar remédios para os males, vituperar e elogiar, e com elementos patéticos, despertar admiração, alegria, pesar, esperança e temor.

\footnotetext{
${ }^{53}$ Sebastiani $(2006,301)$

${ }^{54}$ Grénier (1969, 399).

${ }^{55}$ Cic. Ad. Fam. 5.12.3 (Tradução de A. Chiappetta). Cf. Chiappetta (1996, 24).
} 
Com Cícero, e também para Lívio, a distinção entre história e retórica parece se turvar. A fides do discurso torna-se um critério para a verdade histórica. História e Retórica, nesta visão, parecem não serem disciplinas tão contrárias. 


\section{HISTÓRIA E RETÓRICA}

\subsection{A escrita da História: a Retórica e o "verdadeiro".}

Já tratamos brevemente de algumas relações entre história e poesia épica: a história surge do impulso de explicar o passado racionalmente, e assim como a poesia, confere glória e perenidade aos homens e seus feitos. Diferentemente da poesia, a história buscará afastar-se dos mitos (fabulae). Mas ambos os gêneros não podem ser completamente dissociados da Retórica na Antiguidade:

Though we today see poetry, oratory and historiography as three separate genres, the ancients saw them as three different species of the same genus - rhetoric. All three types of activity aimed to elaborate certain data in such a way as to affect or persuade an audience or readership ${ }^{56}$.

Todos os gêneros, qualquer seja a maneira que organize as informações, e dentro das funções específicas que cada um possui, de alguma maneira necessitam criar fides. Tanto o relato de eventos contra a natureza, como os mitos, quanto de algo "verdadeiro", buscarão algum tipo de persuasão. Era preciso também parecer verdadeiro. As preceptivas da Retórica serviam também ao historiadores, que não tinham outra formação específica. Como apontou Nicolai,

It might seem unnecessary to be reminded that the Greek and Roman historians came from the schools of grammarians and rhetors: the formation of the historian was the same as that of the orator and there was no specifc preparations for the writing of history. A recent work on progymnasmata has surmised that the presentation of facts by historians was influenced by the practice of creating narration (diegema), description (ekphrasis), panegyric (enkomion) and son on ${ }^{57}$.

O autor também afirma ainda que a função paradigmática e educativa da historia a liga a outros gêneros que também tem por finalidade a identificação coletiva e apresentação de exemplos: a tragédia, a oratória, epidítica e deliberativa ${ }^{58}$. Mais uma evidência de que a Retórica também apresentava preceptivas para a escrita da história é o fato de que muitos manuais de retórica apontavam como exemplos de figuras e procedimentos trechos de historiadores:

\footnotetext{
${ }^{56}$ Woodman $(1988,100)$.

${ }^{57}$ Nicolai $(2007,21)$.

${ }^{58}$ Cf. Nicolai $(2007,16)$.
} 
The constant presence of examples taken from historiography in rhetorical treatises is a confirmation of the firm position if historiography in the literary system next to traditional poetic genres (primarily epic and tragedy, but also lyric, elegy, iambus, and comedy) and prose (oratory and philosophy) ${ }^{59}$.

$\mathrm{Na}$ teoria dos gramáticos, havia a classificação de uma parte histórica (historikon meros) na gramática, que derivava da teoria retórica da diêgêsis. Parece claro que os historiadores antigos usaram formas, procedimentos e figuras da oratória. Entretanto, como afirmou Nicolai, os trabalhos dos historiadores não deveriam ser considerados testemunhos duvidosos por causa disso ${ }^{60}$, uma vez que a história era pautada por critérios investigativos que garantiam a verdade.

Como já dissemos, Cícero, na carta a Luceio, pede que Luceio negligencie as leis da história ao utilizar elementos patéticos na narrativa. Este trecho é utilizado por muitos para provar que, segundo Cícero, a ficção era matéria da história. Está implícito no pedido de Cícero que existem leis da história, que não comportariam o uso do patético na narrativa. Assim, alguns podem, erroneamente, depreender desta formulação que o uso da Retórica na história é contrário à possibilidade do verdadeiro a que se propõe a história. É corrente a ideia de que a soma de Retórica e História é necessariamente a ficção como resultado. É o que propõe a crítica antipositivista moderna, que suprimiu a possibilidade do verdadeiro ao propor que no texto tudo é ficção, e que não há no texto nenhuma verdade extratextual, não há relação entre texto e verdade extratextual. Referimo-nos aqui às ideias filosóficas de Nietzsche e Foucault, e à teoria semiótica iniciada por Roland Barthes, que, de uma maneira muito resumida, tratam da impossibilidade de se relatar ou apreender algo imparcialmente. No campo há historiografia moderna, tais ideias refletem-se de uma maneira radical, e polêmica, como veremos, nas teorias de Hyden White.

Em Trópicos do Discurso, White ${ }^{61}$ demonstra que a narrativa histórica não difere, em sua estruturação, da narrativa de ficção. Para ele, as narrativas históricas, artefatos literários, são ficções verbais cujos conteúdos são tanto inventados quanto descobertos e cujas formas têm mais em comum com os seus equivalentes na literatura do que com os seus equivalentes nas ciências. Segundo o autor, para escrever a narrativa histórica, os historiadores reorganizam os acontecimentos e elementos históricos em um enredo, subordinando-os a leis causais e interpretando-os, conferindo assim novos sentidos a estes acontecimentos a partir desta organização. Este procedimento, para ele, é uma operação literária, criadora de ficção. A

\footnotetext{
${ }^{59}$ Nicolai $(2007,21)$.

${ }^{60}$ Nicolai $(2007,20-21)$.

${ }^{61}$ White (1994).
} 
Historiografia, segundo ele, não pode escapar da linguagem figurativa: "toda narrativa não é simplesmente um registro 'do que ocorreu' na transição de um estado das coisas para outro, mas uma redescrição progressiva de conjunto de eventos de maneira a desmantelar uma estrutura codificada num modo verbal no começo, a fim de justificar uma recodificação dele num outro modo no final" ${ }^{62}$. White, entretanto, propõe que as narrativas históricas, aproximadas às narrativas ficcionais, não deixam de ter por isso o status de conhecimento, já que também a literatura sempre nos ensina também algo sobre a realidade; há signos e simbolizações que apontam para a realidade mesmo no texto literário.

Para Hayden White, mais que antipositivista, a linguagem por si só relativiza tudo que é narrado. A Retórica, dessa maneira, como arte do discurso, torna-se arte exclusiva da ficção, e apenas busca a persuasão. Entretanto, como apontou Carlo Ginzburg, as Retóricas Antigas distinguem-se desta redução. Em Relações de Força, o historiador critica diretamente as visões de Hayden White e Roland Barthes, apontando como um erro destas vertentes o julgamento da Retórica apenas como "arte do convencimento", e que desconsidera as concepções antigas da Retórica, como a de Aristóteles, que no início de sua obra Retórica já aponta a disciplina como "análoga à dialética".

Para Carlo Ginzburg, a Retórica Antiga não exclui o verdadeiro como possibilidade: é preciso atentar para a questão das "provas", tratadas na Retórica de Aristóteles. O historiador aponta que estagirita, após afirmar que a retórica é análoga à dialética, revelou que os seus predecessores, em seus tratados sobre a arte do discurso, apenas trataram dos elementos acessórios, e não enfrentaram o principal elemento constitutivo da Retórica, as provas. Aristóteles, na Retórica 1354, critica aqueles que não trataram dos entimemas, núcleo central da prova, e que se dedicaram a questões alheias ao argumento, como as paixões. Segundo Ginzburg, Aristóteles rechaça tanto a posição dos sofistas quanto a posição de Platão, que no Górgias condenara a retórica por ser apenas uma arte de convencer através de afecções, propondo que existe na Retórica um núcleo racional, as provas ${ }^{63}$. Para ele, existem provas [pisteis] técnicas (artísticas), e não técnicas (inartísticas). São provas não técnicas, no âmbito judiciário, os testemunhos, as confissões feitas sob tortura, os documentos escritos e similares, leis e juramentos. Por outro lado, são provas técnicas o exemplo (parádeigma) e o entimema, que correspondem à indução e ao silogismo no âmbito dialético ${ }^{64}$. Os entimemas, adequados para o gênero judiciário (o passado admite a busca da causa e a demonstração [1368a]),

\footnotetext{
${ }^{62}$ White $(1994,115)$.

${ }^{63}$ Ginzburg $(2002,49)$.

${ }^{64}$ Cf. Ginzburg $(2002,49)$.
} 
derivam de quatro pontos: o provável [eikós], no exemplo [parádeigma], a prova necessária [tekmérion], e o signo [semeion]. Quando as conclusões são prováveis, não necessárias, ou os entimemas são baseados em exemplos e signos, estamos ainda no âmbito do verossímil. Mas quando os entimemas são baseados em signos necessários (tekméria), eles permitem chegar a conclusões irrefutáveis:

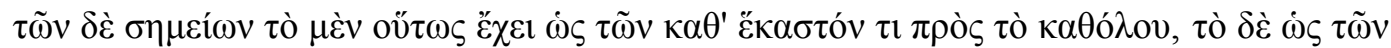

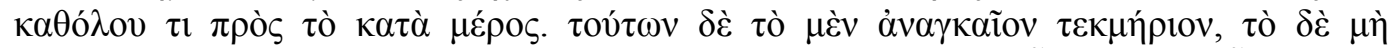

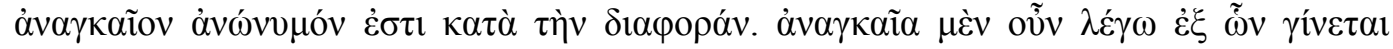

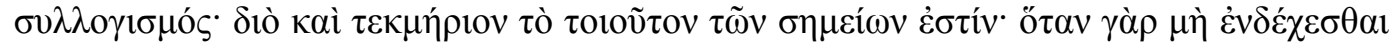

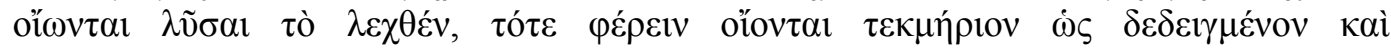

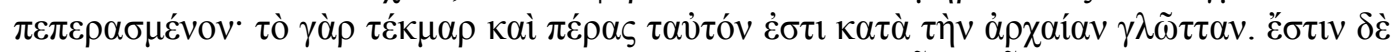

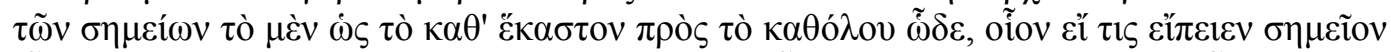

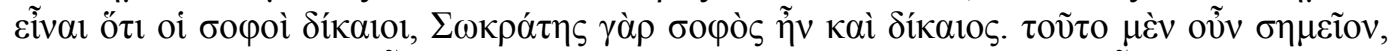

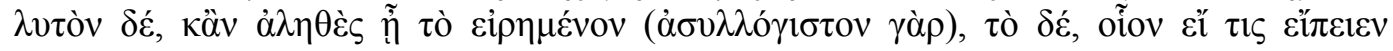

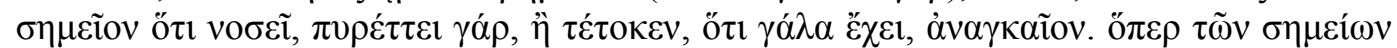

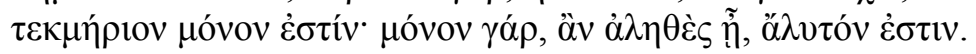

Quanto aos sinais, uns apresentam uma relação do particular para o universal, outros do universal para o particular. Destes sinais, os necessários são os argumentos irrefutáveis, e os não necessários não tem nomes particular que traduza a diferença. Chamo, portanto, necessários àqueles sinais a partir dos quais se pode formar um silogismo. E, por isso, é argumento irrefutável o que entre os sinais é necessário, pois quando se pensa que já não é possível refutar uma tese, então pensa-se que se aduz um argumento concludente ou irrefutável [tekmérion], como se o assuntos já estivesse demonstrado e concluído; visto que tékmar [conclusão] e péras [fim] significam o mesmo na língua antiga.

De entre os sinais, um é como o particular em relação ao universal; por exemplo, um sinal de que os sábios são justos é que Sócrates era sábio e justo. Este é na verdade um sinal, mas refutável, embora seja verdade o que se diz, pois não é susceptível de raciocínio por silogismo. O outro, o sinal necessário, é como alguém dizer que é sinal de uma pessoa estar doente o ter febre, ou de uma mulher ter dado à luz o ter leite. E, dos sinais, este é o único que é um tekmérion, um argumento concludente, pois é o único que, se for verdadeiro, é irrefutável ${ }^{65}$.

Como vemos, para Aristóteles, existem sinais irrefutáveis (tekméria) que podem ser comprovados por meio de silogismo. Se tal sinal for verdadeiro, converte-se em uma prova irrefutável:

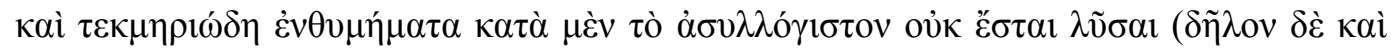

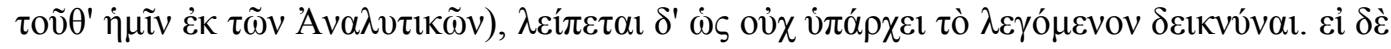

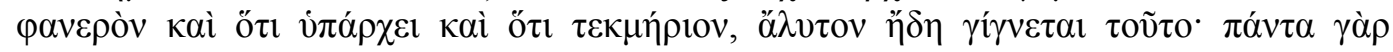

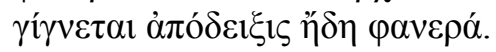

Quanto às provas concludentes e os entimemas baseados nelas, não é possível refutá-los argumentando que são impróprios de um silogismo (o que também já esclarecemos nos Analíticos). Assim sendo, o único caminho que nos resta é que o argumento alegado não

\footnotetext{
${ }^{65}$ Arist. Rhet. $1357 b$ (Tradução de M. A. Júnior, P. F. Alberto e A. N. Pena).
} 
tem qualquer pertinência. Mas, se se admitir que é pertinente e que constitui uma prova conclusiva, então torna-se irrefutável e tudo se converte numa demonstração evidente ${ }^{66}$.

Ginzburg relata ainda rapidamente o estudo em que G.E. M de Ste Croix analisou a expressão to his epi to poly (“o frequente”), na Retórica de Aristóteles e na obra de Tucídides. Eikós, parádeigma, semeion e tekmérion fundamentam a relação cognitiva do historiador com o passado. Ginzburg ressalta que o termo tekmaíromai, e seus correlatos, são utilizados com certa frequência por Tucídides, quando o historiador apresenta um argumento que funciona como prova de dado acontecimento, pois permite deduções, ou quando há um indício forte. Como por exemplo, quando Tucídides vê na distribuição dos templos na cidade uma prova de onde era o centro mais antigo da cidade $(2.15 .3)^{67}$.

Dessa maneira, Carlo Ginzburg, refletindo sobre o trabalho do historiador a partir das questões que a Retórica de Aristóteles propõe com relação às provas, písteis, no âmbito do discurso judiciário, conclui que:

a) a história humana pode ser reconstruída com base em rastos, indícios, semeia;

b) tais reconstruções implicam, implicitamente, uma série de conexões naturais e necessárias (tekmeria) que têm caráter de certeza: até que se prove o contrário, um ser humano não pode viver duzentos anos, não pode encontrar-se, ao mesmo tempo, em dois lugares etc. $\mathrm{E}$

c) fora dessas conexões naturais, os historiadores se movem no âmbito do verossímil (eikos), às vezes do extremamente verossímil, nunca do certo - mesmo que, nos seus textos, a distinção entre "extremamente verossímil" e "certo" tenda a se desvanecer ${ }^{68}$.

Ginzburg demonstra assim que a possibilidade do verdadeiro não está excluída da preceituação retórica aristotélica. Existem tipos de relações necessárias, provas irrefutáveis que podem garantir que algumas coisas aconteceram. Mas Ginzburg reconhece que Cícero contrariou a Retórica aristotélica ao sobrepor as paixões às provas. Quintiliano sim promulgou Aristóteles, ao considerar as provas o núcleo fundamental da Retórica (assunto tratado no livro 5 da Institutio Oratoria $)^{69}$.

A crítica antipositivista moderna, ao igualar o texto histórico ao literário, desconsidera todo o trabalho de investigação judiciária realizado pelo historiador. Ginzburg propõe que ao invés de ver o texto como um artefato literário, deveríamos "deslocar a atenção do produto literário final para as fases preparatórias, para investigar a interação recíproca, no interior do

\footnotetext{
${ }^{66}$ Idem, 1403a.

${ }^{67}$ Ver também o uso de tekmérion em Th. 1.1.1; 1.3.3; 1.20.1; $1.21 .1 ; 2.15 .4 ; 2.1$,2. Cf. Ginzburg $(2002,55-56)$.

${ }^{68}$ Ginzburg (2002, 57-58).

${ }^{69}$ Cf. Ginzburg (2002, 79). Hartog (2001, 163-6) ressalta que com Quintiliano há o retorno para uma maior diferenciação entre história e oratória, diferença mais dissolvida em Cícero.
} 


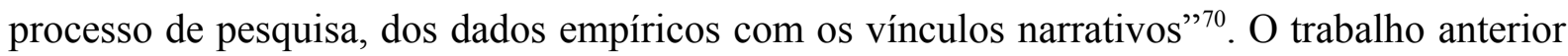
ao texto, a investigação, a busca e a indicação de sinais irrefutáveis (o que o aproxima tanto do orador judiciário quando do juiz que julga o caso), não pode ser desconsiderado, e isso o diferencia do poeta. Mas também não devemos incorrer no outro oposto, e considerar a história uma ciência positiva e considerar que a construção narrativa garante esta verdade. A história é a exposição da investigação, e neste ato de reconstrução o historiador confere explicações aos acontecimentos, ordena-os em uma relação de causa e efeito, e neste sentido ele se move no âmbito da persuasão, buscando a fides. A ideia de White de que o discurso é incapaz de carregar algo verdadeiro parece-nos estranha ao mundo antigo, pois, como já dissemos, a retórica judiciária baseava-se em provas que visavam justamente garantir uma verdade.

Concordamos, assim, que há espaço para algo de "verdadeiro" na narrativa histórica. Entretanto, as provas e documentos são sempre lacunares. O historiador, ao explicar os acontecimentos, ou seja, ao preencher as lacunas dos documentos e provas, os interpreta sempre de uma maneira parcial, preocupando-se mais com um determinado aspecto do que com outro: move-se, assim, no âmbito do provável. Mas em matéria humana nem sempre há um provável, como nas leis da natureza. Segundo Veyne, o real nos escapa por entre o dedos em dois aspectos: a causalidade não é constante e não podemos passar da qualidade à essência, ou seja, a realidade escapa às tentativas de fixá-la em conceitos, palavras ${ }^{71}$.

A discussão entre ficção e historia é muito longa, introduzimos aqui o tema apenas para ficar claro que a Retórica não exclui a possibilidade do verdadeiro, e que, para Lívio, a verossimilhança é um critério para o verdadeiro. A visão de Tito Lívio, entretanto, não é mesma de outros historiadores. Como já dissemos, é muito variada a noção de história entre os antigos, e também variados os critérios de validação do verdadeiro. A preceituação proposta por Cícero na carta a Luceio (que parece ser também a de Tito Lívio), de que se deve elogiar e utilizar do páthos, parece não ter sido unânime. Alguns autores antigos viam um problema entre a linguagem, o uso de alguns procedimentos retóricos e a possibilidade do relato verdadeiro.

Timothy P. Wiseman, em capítulo intitulado "Lying Historians: Seven Types of Mendacity $^{72}$ ", demonstra como alguns historiadores foram acusados de falsidade já na Antiguidade. Wiseman aponta que Luciano, em Quomodo historia conscribenda sit (3-7),

\footnotetext{
${ }^{70}$ Ginzburg $(2002,114)$.

${ }^{71}$ Veyne $(1995,126)$.

${ }^{72}$ Wiseman (1993, 122-46).
} 
aconselha que o historiador distancie-se da narrativa mitológica e também do panegírico, evitando o louvor de governantes e generais. No Prefácio de Verae Historiae, Luciano relata que Ctésias de Cnido, que seria então o predecessor da "história ficcional", descrevia nos seus relatos de viagens monstros nos moldes homéricos ${ }^{73}$. Tácito, no início das Histórias e dos Anais, alerta para a imparcialidade política praticada por historiadores do Principado ${ }^{74}$. Wiseman inclui também entre as mendacidades na historiografia indicadas pelos próprios antigos o uso não apenas da tradição trágica, mas do efeito dramático. O pesquisador cita a introdução de Arrio à sua História de Alexandre, em que o historiador expõe sua metodologia de opção pelas diversas versões: ele diz escolher aquilo mais digno de crença e também o mais digno de se narrar (axiaphêgêtotera). Wiseman destaca que o termo é construído com o termo aphêgêsis, cujo verbo significa "levar" e, portanto, “conduzir" o ouvinte à história. O estudioso defende assim que já na Antiguidade estava dada esta bipartição entre investigação (“digno de crença”) e a narrativa ("digno de ser dito"). A historía como pesquisa é o que diferenciava os grandes historiadores (Tucídides, Políbio, Tácito), mas ela tinha sempre que coexistir com a aphêgêsis. Wiseman destaca que alguns historiadores eram criticados por serem governados apenas pela aphêgêsis. Ele ressalta que, para Sêneca, os historiadores eram contadores de histórias, e que contadores de histórias eram mentirosos ${ }^{75}$. Também para Políbio, o problema aparece na crítica, já mencionada antes, à historiografia trágica.

O uso vivacidade, enárgeia e euientia, pelos historiadores, assunto que trataremos em mais detalhes no capítulo seguinte, pode ter sido visto por alguns como um empecilho à verdade. Políbio, em 2.56.6-8, reprova que Filarco tenha feito um relato dramático e vívido da queda de Mantinea para enfatizar e realçar a crueldade dos Antígonos e dos Macedônios. Em Tito Lívio, ocorre algo parecido na descrição da Batalha de Canas; a vivacidade da descrição coloca diante dos olhos do leitor a violência e crueldade dos cartagineses e de Aníbal; trata-se, portanto, de um argumentum. Assim, quando o historiador cria o efeito visual, estamos no âmbito do convencimento por paixões e, portanto, no âmbito do verossímil e da ficção. Este efeito, quando não acompanhado da investigação, parece ter sido condenado por Políbio. Entretanto, como já mencionamos, por Cícero ele é recomendado na carta a Luceio. Wiseman continua apresentando ainda dois elementos considerados por alguns antigos falácias historiográficas, que a meu ver não estão dissociados do uso da vivacidade que mencionamos

\footnotetext{
${ }^{73}$ Wiseman $(1993,132)$.

${ }^{74}$ Cf. Wiseman $(1993,126-128)$.

${ }^{75}$ Cf. Wiseman $(1993,137)$. O estudioso depreende tal ideia dos dois primeiros parágrafos da Apocoloquintose do Divino Cláudio.
} 
acima: o excesso de detalhamento e a sua ausência. Políbio (3.33.17), tratando da invasão de Aníbal, contrasta sua informação acurada e pautada em documentos contemporâneos com o relato de outros historiadores que inventaram detalhes para aumentar a verossimilhança, os quais ele chama de axiopistôs pseudomenoi, "mentirosos plausíveis" Políbio reclama desta técnica, mas provavelmente tal "reconstrução criativa" de detalhes era aceita pela maioria dos escritores, trata-se da inventio necessária para que a narrativa se torne convincente. Por outro lado, a ausência de detalhes também poderia ser vista com maus olhos, uma vez que a verdade, o entendimento dos assuntos públicos, depende da análise detalhada dos eventos de acordo com as causas, seu desenvolvimento e consequências (Políbio 3.32.6; Cícero, De Orat. 2.63). Resumindo, o detalhamento excessivo de eventos do passado distante poderia parecer falsidade, assim como a falta de detalhamento no relato de eventos recentes. Brevidade neste caso poderia parecer mentira ${ }^{77}$.

Plutarco, cerca de seis séculos depois de Heródoto, compõe um vitupério sobre a obra do historiador. No ensaio Sobre a malignidade de Heródoto, acusa o historiador grego de ter composto deliberadamente sua narrativa com má-fé, e ter ocultado, através de um estilo simples e natural, e burlas graciosas, opiniões infundadas e enganosas sobre estados e homens grandiosos gregos (Plu. Moralia, 874b-c). Heródoto teria agido com malevolência ao adjetivar injustamente feitos narrados, amplificar erros das personagens, suprimir feitos nobres, preferir versões desfavoráveis sobre feitos de quem quisesse vituperar, caluniá-los, depreciar alguns acontecimentos narrados, privilegiar ações de outrem ou de um povo, e expor sua opinião como se fosse uma informação precisa. Plutarco acusa a narrativa de Heródoto de filobárbara, e rebate alguns argumentos utilizados por Heródoto para provar algumas versões sobre fatos. Assim, parece claro que Plutarco tem consciência de que a narrativa histórica não está isenta de estratégias discursivas e que ela busca a persuasão. Mas ele identifica uma malevolência da parte de Heródoto, justamente por ser uma narrativa que se pretendesse como verdadeira; segundo o autor, a pior das injustiças é dar a impressão de justo quando não se é (Plu. Moralia. 854f). Plutarco critica o fato de a parcialidade de Heródoto estar mascarada.

Assim, podemos observar que até mesmo os historiadores antigos pensaram o conflito entre a verdade, almejada através de investigações, e a elaboração de uma narrativa convincente. Muitas vezes, aqueles que se preocuparam somente com o estilo e composição da narrativa, como a historiografia trágica, foram acusados de historiadores ruins, por não

\footnotetext{
${ }^{76}$ Cf. Wiseman (1993, 141-2).

${ }^{77}$ Cf. Wiseman $(1993,143-4)$.
} 
serem sustentados por investigações. A parcialidade, o elogio, o vitupério, não eram vistos com bons olhos por alguns. Mas é difícil pontuar o que era permitido ou não na narrativa do historiador; de maneira nenhuma parece ter havido um consenso sobre isso. A relação do historiador com a verdade variou muito, alguns são críticos e se importam com evidências, outros se importam com o deleite emocional, e, para outros, o papel moral é mais importante ${ }^{78}$. Apenas podemos dizer que há uma tendência, nos ditos grandes historiadores como Tucídides e Políbio, em entender a presença da historía, da investigação, como um critério para distinguir um bom, ou verdadeiro, historiador. E quanto mais nos afastamos desta prerrogativa, mais difícil torna-se diferenciar a história dos outros gêneros no que diz respeito ao seu caráter ficcional e estrutura.

Evidências documentais, provas irrefutáveis e silogismos compreendem apenas parte da narrativa. No relato, entretanto, outras evidências, textuais, como o detalhamento, a vivacidade, argumentos patéticos, criam também a semelhança com a verdade. Talvez o uso deles em excesso, ou se não coadunados com a investigação, fosse criticado por alguns historiadores, mas, de alguma maneira, todos valeram-se de procedimentos "literários" em sua narrativa.

No relato das ações que envolvem Aníbal, Tito Lívio busca evidências sobre alguns acontecimentos e em alguns momentos é bastante crítico com o que dizem suas fontes. Mas a escolha entre uma versão e outra é feita com base no que é mais provável. A investigação de Lívio, concernente a sua tarefa de historiador, na busca de evidências sobre se Aníbal realizou uma ação e de que maneira, interfere no retrato construído do general. Não devemos assim desconsiderar todo este trabalho anterior ao texto, até porque textualmente isso também funciona como uma auctoritas do historiador. Uma vez que o verossímil passa pelo crivo da probabilidade (argumentos de probabilidade, eikós) e está assentado nos costumes, podemos imaginar que o texto histórico, para ser verossímil, não pode se distanciar muito daquilo que é narrado pela tradição histórica anterior; não há como fugir do relato de acontecimentos que eram conhecidos por gerações e gerações, e da fama que alguns caracteres possuíam, caso contrário haveria diminuição da fides, da credibilidade. Assim como Ginzburg, entendemos que a Retórica e o verossímil não exclui a possibilidade do verdadeiro, que não eram elementos opostos, e que o verdadeiro era buscado e estabelecido com base em provas racionais.

Entretanto, mesmos os acontecimentos que não podem ser negados, ao serem mimetizados, passarão pelo crivo do verossímil e pela subjetividade do historiador antigo, que

\footnotetext{
${ }^{78}$ Cf. Levene (2010, 392).
} 
vê a sucessão dos acontecimentos de acordo com uma interpretação própria. Lívio, por exemplo, de uma maneira geral, organiza os acontecimentos de acordo com sua visão moral da história, associando a boa Fortuna ao homem virtuoso. É preciso então analisar a história de maneira indireta. O êthos de Aníbal é construído por Tito Lívio muitas vezes através de ações descritas vividamente, entre outros procedimentos narrativos. Para Lívio, alinhado mais à concepção historiográfica de Cícero, o verossímil alia-se ao verdadeiro, e, assim, a vivacidade, o despertar de paixões, entre outros procedimentos retóricos, contribuem para a legitimação do status de verdade que a história arroga para si: o efeito da visão daquilo que é narrado simula justamente o ato da visão, que é o sentido que, na historiografia, mais garante a verdade. Assim, o próximo capítulo estudará, de maneira breve, o efeito da enárgeia na historiografia.

\section{2. Écfrase e Enargia}

Uma vez que o trabalho se propõe a analisar a construção do êthos e imago de Aníbal, e tal caracterização se dá por meio do discurso, analisamos aqui um dos procedimentos retóricos que permite ao leitor ver com seus próprios olhos, olhos da mente, o agir de Aníbal. Trata-se da écfrase, e de sua principal qualidade, a enargia.

O objetivo deste capítulo não é esgotar o estudo da ékphrasis e da enárgeia, nem tampouco esquematizar exaustivamente os termos correlatos que foram utilizados ao longo do tempo pelos autores antigos para referir à descrição e ao "dispor diante dos olhos", tarefa essa já brilhantemente realizada pelas estudiosas Ruth Webb, que será constantemente citada nesse capítulo, e Melina Rodolpho, ambas em obras recentes sobre a écfrase. Apenas buscaremos verificar como o procedimento foi definido pela maioria e qual a sua aplicação na historiografia.

A teorização mais antiga acerca do procedimento retórico da écfrase , segundo temos conhecimento, pode ser encontrada nos Progymnasmata, ${ }^{79}$ atribuídos a Hélio Teão, datados do século I d. C.. O conceito é explicado detalhadamente também nos exercícios preparatórios posteriores, atribuídos a Hermógenes de Tarso, séc. II, Aftônio, séc. IV d.C., e Nicolau de Myra, professor de retórica em Constantinopla no terceiro quarto de séc. V.. Embora o termo

\footnotetext{
79 “'Progymnasmata' means 'preliminary exercises', preliminary that is to the practice of declamation in the schools of rhetoric, which boys usually began between the age of twelve and fifteen. The progymnasmata were assigned by Greek grammarians to students after they had learned to read and write as preparation for declamation and were continued in rhetorical schools as written exercises even after declamation had begun" (“Introduction", Progymn., Edited by Kennedy, 2003).
} 
tenha sido utilizado somente neste período, os autores ilustram o procedimento, como veremos, citando trechos de autores muito anteriores, como Homero e Tucídides, o que nos autoriza verificar a ocorrência da écfrase também nas obras de Tito Lívio e Nepos.

Segundo Teão, “A ékphrasis é um discurso descritivo (periêgêmatikos) que apresenta o objeto retratado vividamente [enargôs] diante dos olhos. Pode haver ékphrasis de pessoas, eventos, lugares e períodos de tempos ${ }^{80}$. Esta definição aparece de maneira muito semelhante nos outros Progymnasmata, com exceção da substituição do adjetivo 'periêgêmatikos' por 'aphêgêmatikos', no texto de Nicolau.

Um dos termos chaves nas definições apresentadas pelos Progymnasmata é o enargôs, comumente traduzido por 'vividamente', ou 'claramente'. O adjetivo grego enargês tem os sentidos de, segundo dicionário Chantraine, 'claramente visível, brilhante e evidente'; é composto a partir do tema 'argós', 'de um branco brilhante' ${ }^{81}$. O termo grego enárgeia foi com certa frequência confundida com a energeia, "ato, atividade", que deu origem à energia em língua portuguesa. Houve esta confusão na tradição manuscrita de um trecho da Retórica de Aristóteles (1411b, 33-4), por exemplo ${ }^{82}$. Entretanto, etimologicamente não são comuns. Nos poemas homéricos, enargês é associado à presença manifesta dos deuses (Ilíada, XX, 131 e Odisséia XVI, 161), ou seja, podemos associar ao "tornar presente diante dos olhos". Trata-se de uma experiência imediata.

Para Hermógenes, a clareza e a vividez (enárgeia) qualificam a écfrase:

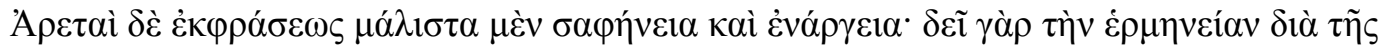

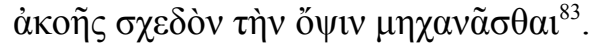

As virtudes da écfrase são principalmente a clareza e a vividez; pois a expressão traz quase para diante visão através do sentido da audição.

Segundo o rétor, clareza e vividez caracterizam a écfrase, para que ela possa forjar, construir pela arte (mêkhanâstai), a visão através da audição. Nicolau apresenta claramente a enárgeia como a qualidade que diferencia a écfrase de uma narração comum, a diêgêsis, que apenas faz uma descrição clara das ações, enquanto a primeira busca transformar os ouvintes em espectadores ${ }^{84}$. O retor exemplifica a diferença dizendo que seria próprio da diêgêsis dizer “Os atenienses e os peloponenses lutaram uma guerra”, enquanto seria próprio da écfrase

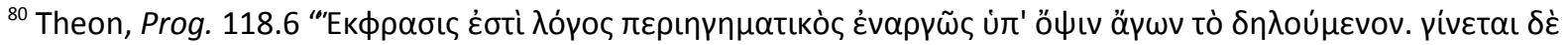

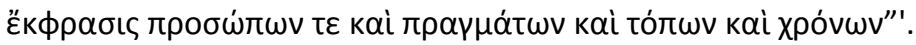

${ }^{81}$ Chantraine (1968): “Enargos: clairemente visible, brillant, evident. Composé possessif avec le préverbe endu type enteges d'un theme en $\mathrm{s}^{*}$ argos (Argós: de um branco brilhante).

${ }^{82}$ Cf. Ginzburg $(2007,19)$.

${ }^{83}$ Hermog., Prog. 10.23-25.
} 
dizer que cada lado fez estas e aquelas preparações e de que maneira usaram as armas ${ }^{85}$. Dessa maneira, para Nicolau a enárgeia não é apenas o que torna uma narrativa clara, como a narratio, da qual uma das virtudes principais segundo a tradição retórica dos manuais seria a perspicuitas, a clareza. Segundo o autor, mais que uma narrativa clara, a enárgeia tenta transformar os ouvintes em espectadores. É esta característica, o dispor diante dos olhos, a influência da audiência, que diferencia a écfrase da diêgêsis, segundo o autor, assim como o detalhamento na descrição [kata méros], uma vez que na narratio o objeto é apresentado de maneira geral [ta kathólou].

Demétrio, em Sobre o Estilo, aponta que a enárgeia advém de uma acumulação de detalhes, de circunstâncias concomitantes: "Aqui a vividez [enárgeia] depende do fato de que são mencionadas todas as circunstâncias concomitantes e nada é omitido". ${ }^{86}$

João Sardiano, a quem é atribuído o Commentarium in Aphtonii Progymnasmata, escrito na primeira metade do século 9 d. C. ${ }^{87}$, comentando o "dispor diante dos olhos" [hup' opsin agôn], afirma que ele se dá pelo detalhamento da descrição (kata méros) e pela clareza; que a narração é composta de maneira condensada, enquanto a écfrase de maneira detalhada (leptomerôs), é um discurso claro e vivo que faz todos imaginarem e verem o que nunca foi visto, imitando a arte da pintura ${ }^{88}$. Mais adiante, Sardiano retoma o tema das virtudes da écfrase, comentando os exercícios preliminares de Teão, e complementa que a linguagem clara e vívida "pinta a verdade para (ou com) a imaginação (phantasía) ${ }^{89}$ Para o comentador, a écfrase proporciona aos olhos sensíveis uma impressão (túpon), e à imaginação (phantasía), uma pintura verdadeira. Antes de tratarmos do efeito da écfrase e da enárgeia na mente, ou seja, a phantasía, atentemo-nos para outro termo chave nas definições da écfrase pelos Progymnasmata.

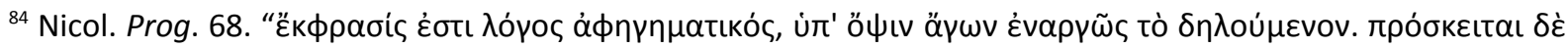

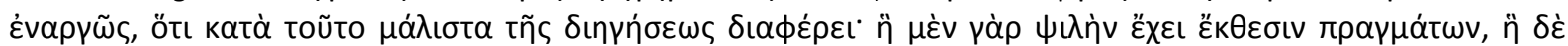

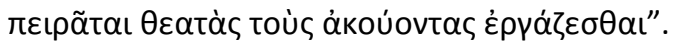

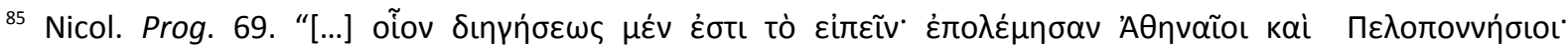

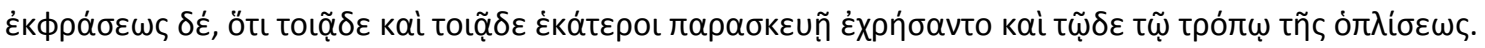

${ }^{86}$ Demetr. Eloc. 4.209 apud Ginzburg $(2007,21)$.

87 Segundo Kennedy $(2003,173)$, Hugo Rabe na edição Teubner identificou João Sardiano com um bispo de Sardis, a quem Teodoro o Estudita enviou uma carta antes de 850. Se isto é correto, o comentário data então da primeira metade do século nove.

${ }^{88}$ J. Sardiano, parágrafo 216. In: Webb (2009, 208 - Apendix A).

${ }^{89} \mathrm{~J}$. Sardiano, parágrafos 224-225. Ibidem.
} 
Ruth Webb destaca que o uso do termo periêgêmatikos, o qual foi traduzido por "descritivo", sugere uma descrição mais elaborada, e não somente uma diêgêsis (narração, relato, exposição). Trata-se de uma descrição circular em torno de um objeto ou espaço. Segundo a autora, o termo aponta para uma analogia entre percurso e discurso ${ }^{90}$. O ouvinte é levado a percorrer um caminho através da descrição oferecida pelo autor, que é como um guia do espaço percorrido. Nicolau acaba por neutralizar esta especificidade do termo utilizado pelos outros retores ao usar o correlato aphêgêmatikos, "discurso de exposição." 91 Entretanto, o termo parece ser importante para a caracterização da écfrase como uma forma mais específica de discurso enargês, designado como um lógos periêgêmatikós. Segundo Sandrine Dubel, o adjetivo, cujas únicas três ocorrências são as definições de Teão, Hermógenes e Aftônio, aponta para um tipo específico de enárgeia: "Parece-me que com o adjetivo periêgêmatikós tocamos em uma forma de escrita de evidência - de uma evidência que não se não tenha o efeito do imediatismo da pintura, mas que se implanta através do movimento do olhar"92. A tradução do termo por "discurso descritivo", é também considerada insuficiente pela autora, que afirma que o termo refere-se a um modo particular de exposição. "Periêgeisthai", segundo Dubel, "pode, essencialmente ser entendido como 'ir ao redor de algo (acusativo), com alguém (dativo), para lhe mostrar"'93. O conceito contempla, assim, que há um movimento descritivo, e que parece haver um guia neste percurso. O comentário de João Sardiano ao adjetivo periêgêmatikós já havia apontado para este mesmo sentido. O comentador afirma que se refere ao relato detalhado, parecendo ir ao redor de algo através do discurso, como alguém que chega a Atena e é guiado pela cidade, mostrando o ginásio, os Pireis e outras cenas; para ele, o discurso que relata (aphêgeomai) tudo em ordem, relatando tanto a ação quando a pessoa, detalhadamente, é chamado periêgêmatikós ${ }^{94}$. Vemos que tal discurso é entendido pelo comentador como um olhar direcionado, que percorre o objeto descrito. O olhar é que está em movimento, independente de ser descrita uma ação ou um objeto estático. Mais uma evidencia sobre o conceito do termo é o fato de uma obra geográfica de Hecateu de Mileto, em que descrevia lugares da Asia, Egito e Líbia, intitulada Periodos Ges, ter sido chamado posteriormente de Periegesis ${ }^{95}$.

\footnotetext{
${ }^{90}$ Webb $(2009,54)$.

${ }^{91}$ Cf. Dubel $(1997,253)$.

92 Dubel $(1997,255)$. A autora utiliza o termo 'évidence' referindo-se à enárgeia, que foi também chamada de euidentia nas letras latinas, como veremos mais adiante.

${ }^{93}$ Dubel (1997, 255).

${ }^{94}$ J. Sardiano, parágrafo 216. In: n: Webb (2009, 205 - Apendix A).

${ }^{95}$ Cf. Fornara $(1983,13)$.
} 
Para Dubel, é este percurso do olhar em movimento que é a fonte da enárgeia: “[...] do fundo da ékphrasis emerge um literatura de viagem pelo texto. Definida como lógos periêgêmatikos, a ékphrasis pode ser entendida como um percurso textual ${ }^{96}$."

No entanto, dispor uma cena diante dos olhos não implica necessariamente que esta cena é estática. Esta associação comum e errônea foi realizada por Lausberg, por exemplo ${ }^{97}$. Segundo Genette, a tradição literária escolar a partir do século XIX acentuou a diferença entre narração e descrição, entendendo a narração como o relato dos eventos e a descrição, acessória e dispensável, como descrição de lugares e pessoas. Entretanto, Gennette ${ }^{98}$ demonstra, assim como deviam também pensar os antigos, que do ponto de vista dos modos de representação, relatar um evento ou descrever um objeto são duas operações semelhantes, que envolvem os mesmos recursos de linguagem. Segundo o estudioso, a diferença mais significativa seria talvez que a narração restitui, através da sucessão temporal de seu discurso, a sucessão igualmente temporal dos eventos, enquanto a descrição deve modular através do sucessivo a representação de objetos simultâneos e justapostos no espaço. Entretanto, o próprio estudioso reconhece que essa distinção perde sua força no texto escrito, onde nem sempre a narrativa é sincrônica aos eventos relatados. Dessa maneira, Genette sustenta que narração (entendida com sentido amplo aristotélico de diêgêsis, mimese indireta, por oposição à mimese dramática) e descrição não diferem nem em modo de representação, nem por originalidade de suas palavras, e nem por autonomia de seus fins. A narração não existe sem descrição, pois aspectos de espaço, das pessoas estão inseridos na narração, embora a descrição não desempenhe sempre o papel principal. Segundo Genette, se a descrição faz alguma fronteira com a narração, trata-se de uma fronteira interna. A descrição está englobada na narração. Consideramos, pois, a descrição como uma narrativa amplificada.

Afastamo-nos, pois desta tendência moderna de diferenciar a descrição como estática e espacial e a narração como ação. Como vimos, segundo os Progymnasmata o que diferencia a écfrase da diêgêsis é a enárgeia e a capacidade de colocar os objetos diante dos olhos da mente do leitor, independente se o objeto é uma ação. Entretanto, existe em meio à narrativa da ação a descrição, uma acumulação de detalhes, uma simultaneidade de ações (por isso o adjetivo periêgêmatikós nos Progymnasmata), um olhar em movimento e um objeto em movimento, mas estas abordagens estão integradas na narração.

\footnotetext{
${ }^{96}$ Dubel $(1997,257)$.

${ }^{97}$ Lausberg (1991, 224, parágrafo 810)

${ }^{98}$ Genette (1969, 50-61).
} 
Como vimos, enárgeia e periêgêmatikós são termos recorrentes nas definições fornecidas pelos Progymnasmata e parecem resumir e caracterizar o procedimento da écfrase. Entretanto, também é recorrente e importante ao efeitos de "dispor diante dos olhos", ação que pode aproximar a écfrase e de outros termos anteriores que já apontavam para uma descrição viva. Segundo Ruth Webb,

[...] the idea of 'placing before the eyes' goes back in rhetorical theory to Aristotle who discusses the power of metaphor to place its subject pro ommatōn, and the definition makes ekphrasis synonymous with other rhetorical terms for vivid description, such as enargeia, diatupōsis, diagraphē ('descriptio', or 'explicatio' in Latin, or simply 'sub oculos subiectio', 'placing before the eyes'). In some contexts, rhetoricians draw fine distinctions between the meanings of the different terms for vivid language. Elsewhere, however, they may be used interchangeably in the same text, as in the case of Menander Rhetor or given identical definitions. Ekphrasis, though, is always the term used in Greek sources for the elementary exercise of 'placing before the eyes', a distinction which may confer a slight more scholastic flavor on the term in some contexts ${ }^{99}$.

Até mesmo entre os autores antigos muitos termos foram utilizados como sinônimos, indistintamente. Entre os modernos, há também a associação desses procedimentos. Heinrich Lausberg, em tratado de Retórica que busca sistematizar os preceitos dos autores antigos, aponta a euidentia, classificada como uma figura de sentença e ornamento do discurso (elocução), como sinônima da enárgeia e de diversos termos:

Se o pensamento, que se pretende pormenorizar, é um objeto concreto de exposição, especialmente uma pessoa ou coisa (que se pretende descrever) ou é um processo coletivo de acontecimentos, mais ou menos simultâneo, chama-se então à pormenorização (mais livre frequentemente, do ponto de vista sintáctico e aplicando, quanto ao pensamento,

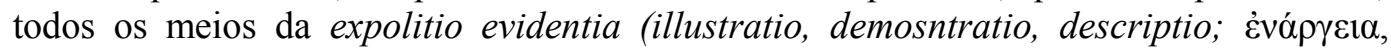
טं pormenorização vívida pressupõe simultâneo testemunho visual, que, na realidade, aparece como teiscopia "observação de uma muralha" e que é criado para objetos ausentes (passados, presentes, futuros), por meio de uma vivência da fantasia ( $\varphi \alpha v \tau \alpha \sigma i ́ \alpha$, visio $)^{100}$.

Quintiliano, no séc. I, afirmou que Cícero utilizava os termos illustratio e euidentia em lugar de enárgeia:

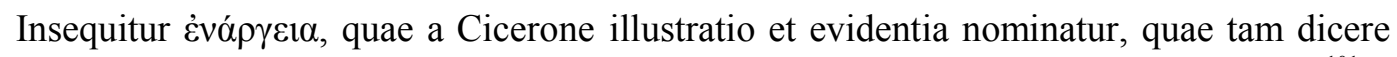
videtur quam ostendere; et adfectus non aliter, quam rebus ipsis intersimus, sequentur ${ }^{101}$.

\footnotetext{
${ }^{99}$ Webb (2009, 51-52).

${ }^{100}$ Lausberg (2004, parágrafo 369).

${ }^{101}$ Quint. Inst. 6.2.32. Tradução nossa.
} 
E assim se segue a enargia, que Cícero chamava de illustratio e euidentia, que parece não tanto narrar, mas exibir uma cena; e a emoção não será diferente de que se estivéssemos presentes em tais acontecimentos.

Quintiliano apresenta neste trecho uma definição de enárgeia, que, segundo ele, nos faz sobretudo ver a cena descrita; ressalta que ela é capaz de despertar nossas emoções (adfectus), como se estivessemos presentes na cena. Este procedimento, segundo Quintiliano, foi denominado illustratio e evidentia por Cícero. No De Oratore, obra da maturidade de Cícero, o adjetivo inlustris e o verbo inlustrare (iluminar, clarear) são utilizados com frequência apontando para a clareza e para o dispor diante dos olhos, e também com o sentido de conferir ornamento ao discurso ${ }^{102}$. Quintiliano, no livro VIII, também indica o termo repraesentatio como sinônimo de enárgeia:

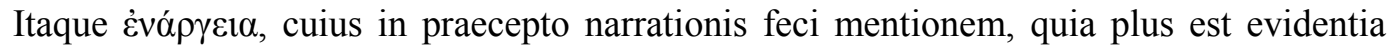
uel, ut alli dicunt, repraesentatio quam perspicuitas, et illud patet, hoc se quodammodo ostendit, inter ornamenta ponamus ${ }^{103}$.

E assim a enárgeia, a qual mencionei quando preceituava sobre a narração, entre os ornamentos, pois a euidentia, que outros chamam de representação, é mais que a clareza; essa mostra-se de algum modo, ao passo que a primeira escancara-se.

Quintiliano considera a enargia uma representação, que aparece presente para o espectador e que ultrapassa a qualidade da clareza. Lausberg, referindo-se a este trecho, afirma que muitos consideraram a euidentia como uma virtude da narração. Assim, na narratio, ela seria uma intensificação das virtudes da clareza e do provável ${ }^{104}$.

Como já dissemos, o termo ékphrasis só aparece no século primeiro de nossa era. Entretanto, outros termos podem ter sido utilizados anteriormente para se referir à descrição vívida e que coloca a cena diante dos olhos. Quintiliano menciona alguns deles. Em 9.2.4044, afirma que Cícero referia-se à descrição capaz de mostrar o objeto como como sub oculos subiectio, enquanto ele, Quintiliano, havia classificado em livro anterior como euidentia. $\mathrm{O}$ retor afirma ainda que outros dão o nome de hipotypôsis a qualquer representação de fatos feita em linguagem viva e que se mostra mais aos olhos que aos ouvidos. Explica ainda que Cícero valeu-se, na defesa de Milão, da translatio temporum, metástasis em grego fenômeno frequentemente utilizado pelos historiadores para conferir imediaticidade às ações descritas - usando o tempo verbal presente no relato de eventos passados, e que isso não era frequentemente usado pelos oradores antigos para criar uma diatypósis, uma descrição vívida.

\footnotetext{
${ }^{102}$ Cf. Cic. De Orat. 2.34, 2.53, 3.152, 3.202 , 3.205 , 3.208.

${ }^{103}$ Quint. Inst. 8.3.62 (Tradução nossa).

${ }^{104}$ Lausberg (1991, 227).
} 
Logo mais adiante em seu texto, Quintiliano afirma ainda que a descriptio dilucida de lugares era nominada por alguns por topographía. ${ }^{105}$.

$\mathrm{Na}$ Retórica a Herênio, manual de retórica escolar do séc I a.C., de autor desconhecido, a descriptio, em meio ao tratamento dor ornamentos de sentença, é assim definida: "Chama-se descrição o ornamento que contém uma exposição perspícua, clara e grave das consequências das ações ${ }^{106 \%}$. A definição da figura demonstratio é a que mais se aproxima do conceito de écfrase e enárgeia tal como preceituados posteriormente: "Na demonstração exprimimos um acontecimento com palavras tais que as ações parecem estar transcorrendo e as coisas parecem estar diante dos olhos" (Rhet. Her. 4.68). A presentificação das ações narradas e o dispor diante dos olhos caracterizam este procedimento, tal como na écfrase.

Outros dois termos que podem ser aproximados ao procedimento da écfrase pelo significado são a effictio e a notatio, se pensarmos em écfrases que têm por objeto pessoas. "Na efígie", diz a Retórica a Herênio, "exprime-se e forja-se com palavras a forma do corpo de alguém, o suficiente para que seja reconhecido" (Rhet. Her. 4.63). A notatio é dessa maneira definida: "A notação é a descrição da natureza de alguém pelos sinais distintivos que, como marcas, são atributos daquela natureza" (Rhet. Her. 4.63.). Logo adiante, o autor do manual afirma que esta figura é útil ao deleite uma vez que desperta a visão:

Huiusmodi notationes, quae describunt, quod consentaneum sit unius cuiuque naturae, uehementer habent magnam delectationem: totam enim naturam cuiuspiam ponunt ante óculos, aut glorioso, ut nos exempli causa coeperamus, aut inuidi aut tumidi aut auari, ambitiosi, amatoris, luxuriosi, furis, quadruplatoris; denique cuiusuis studium protrahi potest in médium tali notatione.

Caracterizações desse tipo, que descrevem o que é conforme à natureza de cada um, trazem, forçosamente, muito deleite, pois dão a ver tudo o que é característico de alguém, seja um vanglorioso - como que tomamos nesse exemplo - , um invejoso, um soberbo, um cobiçoso, um adulador, um amante, um dissoluto, um ladrão um delator, enfim, com a notação, as inclinações de quem quer que seja podem ser exibidas aos olhos de todos"107

Mais um termo provavelmente era usado para referir-se à descrição de caracteres. Lausberg afirma que "el empleo de la evidentia para dar conocer (elogio, vituperio) mediante la descripción personal y la pintura de su comportamiento (por exemplo, em una orgía) se llama xarakterismós" ${ }^{\prime 108}$. O autor cita as ocorrências do termo com este sentido em P. Rutili

\footnotetext{
${ }^{105}$ Quint. Inst. 9.2.41-4.

${ }^{106}$ Anônimo, Rhet. Her. 4.51. Tradução de A. P. C. Faria e A. Seabra.

${ }^{107}$ Anônimo, Rhet. Her., 4.65. Tradução de A. P. C. Faria e A. Seabra

${ }^{108}$ Lausberg (1991, parágrafo. 818).
} 
Lupi Schemata lexeos, 2,7; no Carmen de figuris uel schematibus (148) e em Schemata dianoeas quae ad rhetore pertinent (10).

Independente dos termos usados, nos importa neste trabalho a descrição detalhada e vívida, ou seja, a descrição plena de enárgeia, uma écfrase, portanto, capaz de transformar objetos ou ações ausentes em presentes; capaz de transformar ouvintes em espectadores, despertando em suas mentes a phantasía, ou imaginatio, uma imagem mental. Segundo Melina Rodolpho, o conceito grego de phantasía encaixa-se perfeitamente como efeito da enargia $^{109}$. E Quintiliano o associa ao que os romanos chamam de visio:

Quas phantasias Graeci vocant (nos sane visiones appellemus),per quas imagines rerum absentium ita repraesentantur animo ut eas cernere oculis ac praesentes habere videamur, has quisquis bene ceperit is erit in adfectibus potentissimus ${ }^{110}$.

Aquele que apreende bem as fantasias, chamadas assim pelos gregos (e que nós chamamos de visiones), através das quais imagens de objetos ausentes são representadas na mente como se as víssemos claramente presentes diante dos olhos, este é o mais poderoso sobre as emoções.

Segundo Quintiliano, através das phantasiai as imagens dos objetos ausentes são representadas na mente, de maneira que parecem presentes diante dos olhos. Sardiano também identifica a phantasía como o efeito da écfrase e da enárgeia na mente do espectador ${ }^{111}$. Consideremos, portanto, a phantasía como um impacto na mente, resultante da percepção provocada por uma descrição vívida, que apresenta objetos ausentes diante dos olhos. Sardiano também acrescenta, em trecho adiante de seu comentário, que a descrição vívida pinta a verdade para a imaginação. ${ }^{112}$ Entretanto, Ruth Webb afirma que esta passagem de João Sardiano é obscura, e traduz que o discurso com enárgeia pinta a verdade "para" ou "com" a phantasía.

A discussão sobre conceito grego de phantasía no âmbito filosófico é vasta. Uma vez que a fantasia é o resultado de uma percepção sensível, a ela será diferentemente entendida, como falsa ou verdadeira, conforme a maneira pela qual se entende o conhecimento da realidade/natureza nas diversas correntes filosóficas antigas. Assim, não nos aventuraremos a estudar a fantasia tal qual conceituada no âmbito filosófico antigo ${ }^{113}$, mas apenas no campo da Retórica, onde seu uso é mais restrito, e nos importa.

\footnotetext{
${ }^{109}$ Cf. Rodolpho $(2010,120)$.

${ }^{110}$ Quint. Inst. 6.2.25 (Tradução nossa)

${ }^{111}$ J. Sardiano, parágrafo 217. In: Webb (2009, 206- Apendix A),

112 J. Sardiano, parágrafos 224-225 (Progymnasta, Ed. Kennedy, 2003).
} 
A phantasía, ou visio, neste âmbito, parece significar apenas uma imagem mental, seja a da qual parte o orador, transformando em palavras aquilo que está em sua mente, seja aquela suscitada na mente do ouvinte. Pode ser entendida como o processo da imaginação (imaginatio), ou como o produto da imaginação, ou seja, a imagem formada na mente. Lausberg afirma que "a imagem com que a fantasia reveste o objeto chama-se imago"114. $\mathrm{O}$ termo imago, utilizado para designar similitudes de um modo geral, pode ter sido utilizado também para designar uma imagem mais específica, como a fantasia, imagem mental. Não está implícito no termo um julgamento sobre a relação, se verdadeira ou não, do objeto com a imagem formada. Importa-nos, como afirmou Quintiliano no trecho acima, que o efeito da visão, as imagens mentais, são poderosas sobre as emoções.

Ps. Longino fala sobre o efeito da phantasía, em Do Sublime:

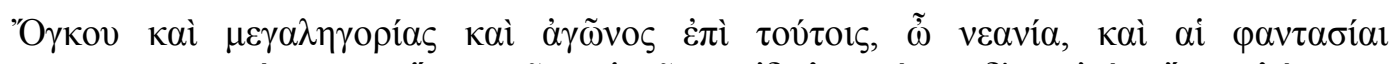

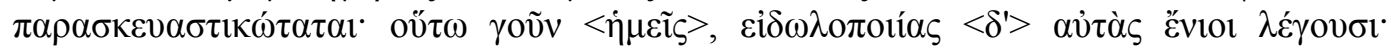

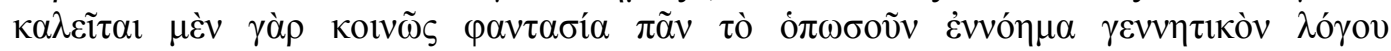

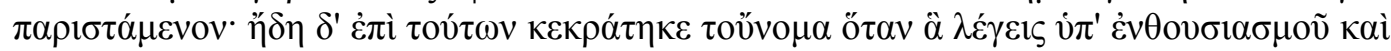

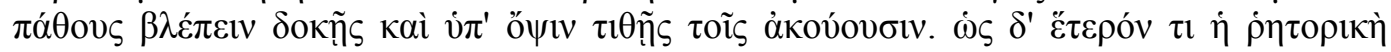

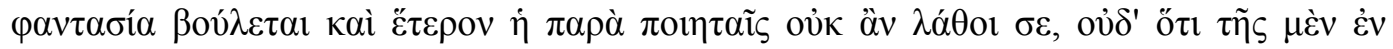

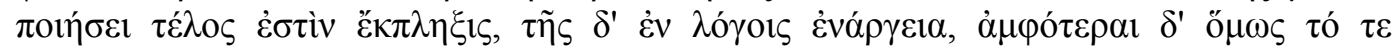
$<\pi \alpha \theta \eta \tau \imath \kappa o ̀ v>~ \dot{\varepsilon} \pi ı \zeta \eta \tau o \tilde{\sigma l ~ \kappa \alpha i ̀ ~ \tau o ̀ ~ \sigma o \gamma \kappa \varepsilon \kappa ı ท \eta \mu \varepsilon ́ v o v . ~}$

Para produzir a majestade, a grandeza de expressão e a veemência, meu jovem amigo, é preciso acrescentar também as aparições, como o mais próprio a fazer. Neste sentido, pelo menos, é que alguns as chamam "fabricante de imagens". Pois se o nome aparição é comumente atribuído a toda espécie de pensamento que se apresenta, engendrando a palavra, agora o sentido que prevalece é esse: quando o que tu dizes sob efeito de entusiasmo e da paixão, tu crês vê-lo e tu colocas os olhos do auditório. Que a aparição dos discursos tende a outra coisa entre os poetas, não te passa despercebido, nem que sua finalidade, em poesia, é o choque, enquanto nos discursos é a descrição animada. Poesia e retórica; no entanto, procuram todas as duas $\mathrm{o}<+>$ e a partilha da emoção. ${ }^{115}$

Ps.Longino afirma que o termo fantasia, traduzido acima por "aparição", foi comumente usado para designar o pensamento a partir do qual se produz o texto, ou seja, a imaginação da qual parte o orador; mas em seguida afirma que o sentido predominante de phantasía refere-se ao efeito de dispor com vividez aquilo que é dito diante dos olhos. Ruth Webb afirma que Ps.Longino está mais interessado no efeito e impacto da phantasía no ouvinte que no estado ontológico do objeto da visão, pois os interesses dos oradores são fundamentalmente práticos, sendo que, para autores e poetas, é suficiente a criação do

\footnotetext{
113 Para sistematização sobre as discussões e divergências entre os filósofos com relação à phantasía, ver Rodolpho (2010, 45-82).

${ }^{114}$ Lausberg (1991, § 1088); Rhet.Her.3.20.33.

115 Ps. Long. XV.1.1-2.4. Tradução de Filomena Hirata.
} 
impacto desejado nos ouvintes ${ }^{116}$. Segundo Longino, a finalidade da fantasia na poesia é a consternação, o terror (ékplêksis), e na oratória a vividez, a enargia; em ambos os territórios busca-se despertar emoções. Suscitando diante dos olhos do ouvinte ou leitor uma determinada cena, o orador ou poeta provoca uma determinada percepção, despertando paixões, que na oratória, podem ser úteis para a persuasão de determinado ponto de vista. Assim, o orador utiliza o tal meio para manipular a percepção do ouvinte sobre o episódio descrito de acordo com os seus interesses de persuasão.

Quando pensamos no conjunto da écfrase, enárgeia (sua qualidade), e phantasía, seu efeito, observamos um processo capaz de colocar o descrito diante dos olhos, útil para persuasão, amplificação e deleite. Nicolau, nos seus Progymnasmata, ao tratar sobre a função da écfrase e os gêneros de causa, afirma que o procedimento é útil no discurso de gênero deliberativo pois frequentemente é necessário descrever aquilo sobre o qual se delibera afim de ser mais persuasivo; no judicial, seja defesa ou acusação, ela é a fonte da amplificação necessária; no discurso epidítico ela é capaz de deleitar a audiência ${ }^{117}$. Assim, segundo o rétor, no gênero deliberativo a exposição detalhada ajudaria na persuasão; no judicial, a écfrase é capaz de amplificar aquilo que é interessante ou para acusação ou para a defesa; e no gênero epidítico a demonstração vívida desperta o prazer. $\mathrm{Na}$ historiografia, encontraremos características destes três gêneros discursivos, assim como da poesia trágica. Na construção do êthos de Aníbal, não somente contribuirá elementos do gênero epidítico, com louvor e vitupério, mas também elementos do judicial, pois pelas ações se conhece o caráter, e suas ações estarão sob o julgamento do historiador e do leitor. Assim, devemos ter em mente quais são as amplificações utilizadas pelos autores para acusar ou defender Aníbal com relação ao seu comportamento. Além disso, a produção da fantasia, além de despertar emoções e trabalhar assim na persuasão, na Historiografia, ao simular o efeito da visão, coopera para a criação do efeito de verdade. Analisemos no próximo subcapítulo, de maneira mais profunda, o uso da vividez na narrativa historiográfica.

\footnotetext{
${ }^{116}$ Webb $(2009,118)$.

117 Nicol. Prog. 70 .
} 


\subsection{O uso da enárgeia na Historiografia}

Para Hélio Teão, (I-II d.C), estruturalmente, a historía é uma sequência de

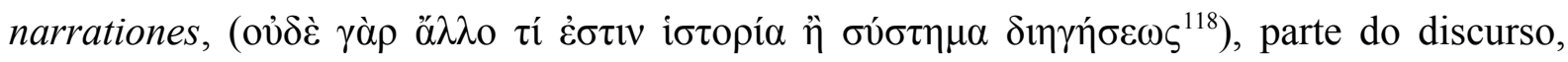
sobretudo judiciário, em que se relatava o que aconteceu com o réu. E como afirmaria depois Nicolau, na narração a écfrase pode ser útil para amplificação de argumentos para a defesa ou acusação, conforme o trecho que mencionamos há pouco.

Teão afirma que descrição ecfrástica foi usada com frequência pelos historiadores:

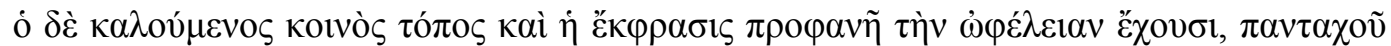

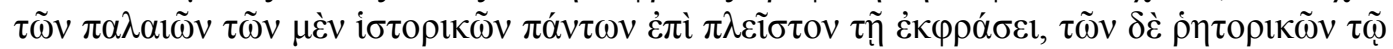

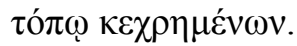

O que é chamado de lugar-comum e écfrase tem claro proveito, uma vez que os antigos os empregaram em muitos lugares, todos os historiadores frequentemente utilizaram a écfrase e os oradores o lugar-comum ${ }^{119}$

Os autores dos Progymnasmata, em meio à teorização sobre a écfrase, apresentaram como exemplos do procedimento, principalmente, trechos de Homero e Tucídides. Teão, após dizer que a écfrase pode ter por objeto pessoas, eventos, lugares e períodos, apresenta como exemplo de écfrase de pessoas as passagens de Heródoto no qual o historiador descreve a íbis, os hipopótamos e crocodilos do Egito. ${ }^{120}$ Logo em seguida, Teão afirma que existem écfrases de tropos (maneira como algo foi realizado), e além do escudo de Aquiles homérico, cita como exemplos passagens de Tucídides e Ctesias ${ }^{121}$. Aponta novamente Tucídices, agora como exemplo de écfrase mista, que comporta tempo e evento, como a batalha noturna (2.25), e também Filisto de Siracusa ${ }^{122}$. Ps.Hermógenes também cita Tucídides como modelo do mesmo tipo de écfrase ${ }^{123}$. Tucídides é o autor mais citado nos exemplos de Aftônio ${ }^{124}$, quando este fala sobre os objetos da écfrase. O autor aponta como exemplos de écfrases de eventos as descrições das batalhas navais e por terra do historiador, e a descrição que Tucídides faz do

\footnotetext{
${ }^{118}$ Theon, Prog. 60.5-6.

${ }^{119}$ Theon, Prog. 60. 1-22 (Tradução nossa).

${ }^{120}$ Theon, Prog. 118. As passagens de Heródoto referidas são $2.76 ; 71 ; 68$.

${ }^{121}$ Theon, Prog. 118 . "And the construction of siege engines in Thucydides: [beginning] 'they cut a long beam in two and hollowed it out completely'. And in book 9 of Ktesias: 'The Lydians, upon seeing at dawn from far away the forms of the Persians set up on long pieces of wood against the ramparts were put to flight, since they believed that the acropolis was full of Persians and had already been taken'". As passagens correspondem a Tucídides 2.75-8 e 7.45-5, e Ctésias, Persika, F9b.

122 Theon, Prog. 119. "An ekphrasis may also be of a mixed type, such as the night battles in Thucydiddes and Philistos, for night is a time while the battle is an event".

${ }^{123}$ Hermog. Prog. 22.

${ }^{124}$ Aphth. Prog. 37.
} 
porto de Cheimerion como exemplo de écfrase de lugar. E a narração da batalha noturna da Sicília por Tucídides é também citada como exemplo de écfrase mista, no caso, que combina evento e tempo.

Outros autores antigos apontaram para o uso da écfrase e do caráter vívido das descrições contidas em textos de historiadores. Plutarco, em Sobre a glória dos atenienses, afirma que Tucídides empregava a enárgeia a fim de provocar nos leitores, transformados em espectadores, emoções em relação aos acontecimentos narrados:

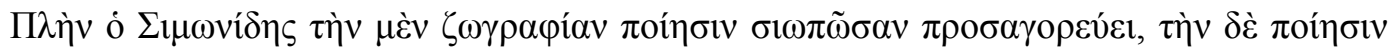

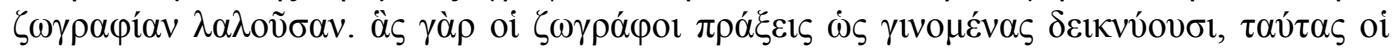

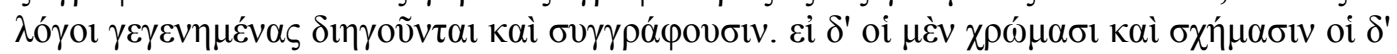

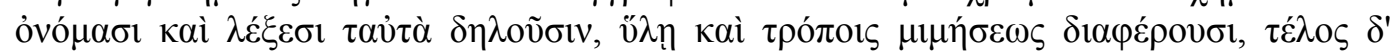

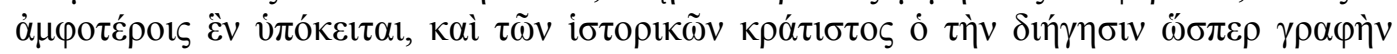

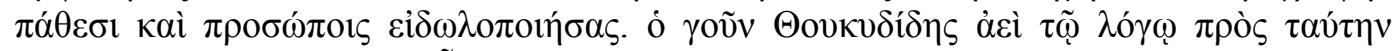

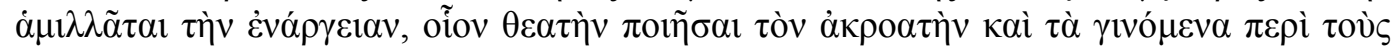

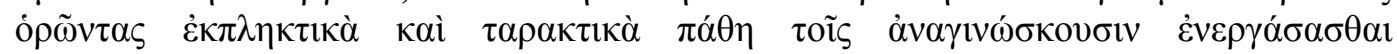
$\lambda \imath \chi v \varepsilon v o ́ \mu \varepsilon v o s$.

Apenas Simônides declara que a pintura é poesia calada, e a poesia, pintura falante. Pois os pintores pintam ações como se ocorrendo, e quando ocorridas os discursos narram e compõem. Se, por um lado, os primeiros demonstram com cores e traços as mesmas coisas que os segundos com nomes e enunciados, por outro diferem pela matéria e maneira da imitação, mesmo sendo uma só a finalidade de ambos; o melhor dos historiadores é o que figurativiza a narrativa como uma pintura com emoções e personagens. Tucídides sempre se empenha visando o vigor do texto, como se ambicionasse tornar espectador o ouvinte e produzir nos leitores emoções comoventes e chocantes em relação aos acontecimentos narrados ${ }^{125}$.

Plutarco, na vida de Artaxerxes, identifica a mesma vivacidade nas descrições realizadas por Xenofonte:

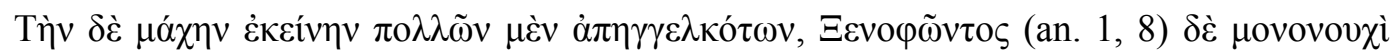

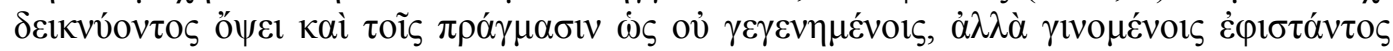

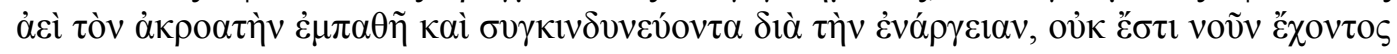

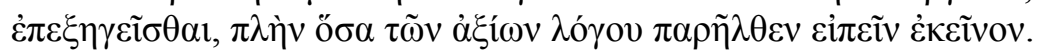

Tendo muitos já narrado esta batalha, e entre os quais Xenofonte, que a descreveu de maneira que quase a apresenta a nossa vista, pintando os acontecimentos não como passados, mas como se estivessem acontecendo no presente, fazendo, com a vividez da expressão, o leitor sentir emoções e perigos; convém-me descrever apenas particularidades dignas de memória omitidas por aquele ${ }^{126}$.

Podemos notar que, para Plutarco, o uso da enárgeia pelo historiador Tucídides é capaz de colocar a ações diante dos olhos, e provoca afecções patéticas no público,

\footnotetext{
${ }^{125}$ Plu. De Gloria Atheniensium, 346f-347a. Tradução de B.B. Sebastiani, apud Sebastiani $(2007,72)$.

${ }^{126}$ Plu. Art. 8.1. Tradução nossa.
} 
promovendo o envolvimento do leitor na cena descrita, como se participassem do evento. Esta mesma vivacidade Plutarco encontra em Xenofonte. O trecho também aponta para uma diferença entre a narrativa histórica, que descreve em detalhes grandes batalhas, e a biografia, na qual Plutarco diz que apenas relatará particularidades dignas de memória omitidas pela historiografia. Mas isso é assunto para a última unidade de nossa pesquisa.

Como Plutarco afirmou, na narrativa com enárgeia os eventos passados são trazidos para o presente. Para isso contribui o procedimento da translatio temporum, ao qual se referiu Quintiliano (9.2.41). Lausberg também inclui tal procedimento entre os meios de expressar a euidentia:

Incluyendo estos tres modos [persona, logo, tempore] cabe distinguir los seguientes medios de expresarse la evidentia: el detallamiento del conjunto del objeto, el empleo del presente, el empleo de los adverbios de lugar expressivos de la presencia, el apostrofe a las personas que aparcen en la narracion, el estilo directo de las personas que intervienen en el relato ${ }^{127}$.

Ps.Longino exemplifica o procedimento citando uma translatio temporum de Xenofonte (15), e em seguida identifica em Heródoto o transporte do ouvinte à cena descrita através da interpelação do leitor:

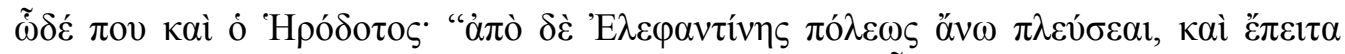

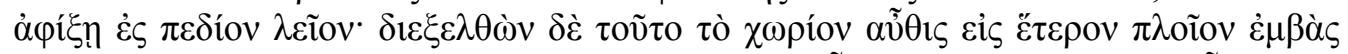

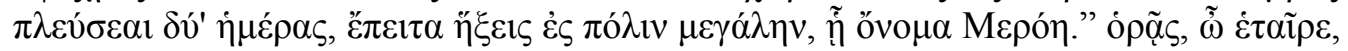

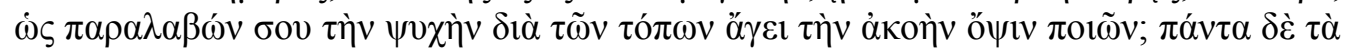

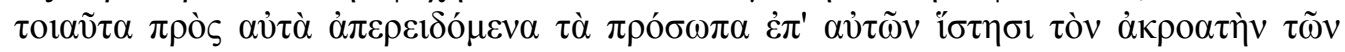
$\dot{\varepsilon} v \varepsilon \rho \gamma \circ u \mu \varepsilon \dot{\varepsilon} \omega \omega$.

E Heródoto, mais ou menos, assim: "A partir da cidade de Elefantina, navegarás rio acima e, em seguida, chegarás a uma planície lisa; após ter atravessado essa região, de novo pegarás uma outra embarcação e navergarás dois dias; em seguida chegarás a uma grande cidade, cujo nome é Méroe". Vês, meu amigo, como ele pega tua alma e a leva através dos lugares, fazendo da audição a visão? Todas as coisas desta espécie, quando se dirigem às próprias pessoas, conduzem o ouvinte diante dos próprios acontecimentos. ${ }^{128}$

Segundo Ps.Longino, Heródoto é capaz, com suas descrições e figuras, de conduzir a alma do ouvinte através dos lugares e ações descritas, introduzindo-o no meio do evento narrado. Em écfrases de lugares, fica mais evidente a qualidade periegética do precedimento. O percurso do olhar na descrição acompanha o percurso no espaço.

\footnotetext{
${ }^{127}$ Lausberg (1991, par. 812).

${ }^{128}$ Ps.Long., Do Sublime, 26.2. (Trad. De Filomena Hirata)
} 
No trecho em que refere-se à Tucídides, Plutarco compara o historiador ideal ao pintor, que representa com vigor caracteres e emoções. Luciano de Samóstata, em Como se escreve a História, também caracteriza o historiador como aquele que faz uma pintura vívida:

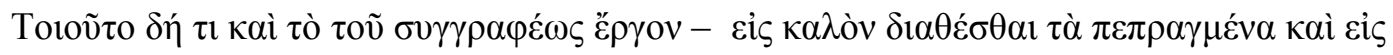

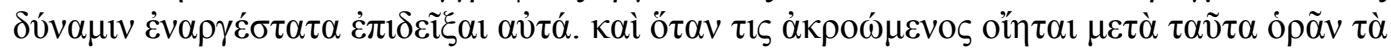

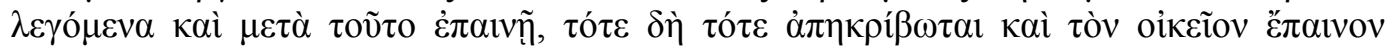

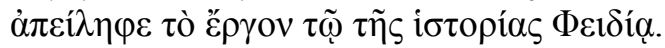

Justamente essa é também a tarefa do historiador: ordenar os acontecimentos de forma bela e mostrá-los de maneira mais clara possível [enargéstata]. Quando, escutando-o, alguém julga ver o que é dito e em seguida elogia, então, sim, sua obra está perfeita, tendo ele recebido um elogio apropriado a um Fídias da história ${ }^{129}$.

Para Luciano, a tarefa do orador é iluminar e vivificar os eventos o máximo possível, a ponto de fazer o ouvinte achar que está vendo a cena descrita, tal como pintava Fídias.

Através dos trechos, podemos perceber que os autores consideravam importante o uso da enárgeia e o envolvimento do leitor/espectador no evento descrito. A participação do ouvinte na cena o leva a uma vivência imediata dos eventos, o que contribui para o efeito de verdade dos eventos narrados. Como afirmou Políbio, em 20.12. 8, "Não é o mesmo julgar coisas por ouvir dizer ou por ter sido testemunha delas: há uma grande diferença. Uma convicção fundada no testemunho ocular [hê kata tên enargeian pistis] sempre vale mais do que qualquer outra" 130 .

A enárgeia apresenta-se, portanto, importante, uma vez que simula a experiência da visão, considerada um critério de verdade para os historiadores, conforme apontaram Políbio e Luciano. Ela torna uma prova ou argumento presente. O historiador Carlo Ginzburg ressalta que muitos estudiosos respeitados da historiografia grega e romana reconheceram, partindo dos trechos citados de Plutarco, que a écfrase, era o objetivo nas narrativas históricas. Citando Hermann Strasburger ${ }^{131}$, afirma que a ékphrasis

era uma noção que abarcava um espaço mais vasto, em que entravam cenas de batalhas repletas de páthos, que peste de Atenas de que fala Tucídides, descrições de caráter geográfico ou etnográfico (ekphraseis tou topou). Se a enargeia era o objetivo da ekphrasis, a verdade era o efeito da enárgeia ${ }^{132}$.

\footnotetext{
${ }^{129}$ Luciano, Hist. Conscr., 51 (Tradução de Jacyntho Lins Brandão, in Hartog, 2001, 231).

${ }^{130}$ Plb. 20. 12.8, apud Ginzburg (2007, 19-20). Cf. também Luciano, Hist. Conscr. 29.

${ }^{131}$ H. Strasburger, Die Wesensbestimmung der Geschichte durch die antike Geschichtsschreibung (1975).

${ }^{132}$ Ginzburg (2007, 23-24).
} 
Segundo Ginzburg, podemos imaginar uma sequência desse gênero: narração histórica - descrição - vividez - verdade. Assim, “'a diferença entre o nosso conceito de história e o dos antigos de resumiria da seguinte forma: para gregos e romanos a verdade histórica se fundava na evidentia; para nós, nos documentos (em inglês, evidence). [...] O critério definitivo de verdade era considerada antes de tudo uma questão de persuasão, ligada só

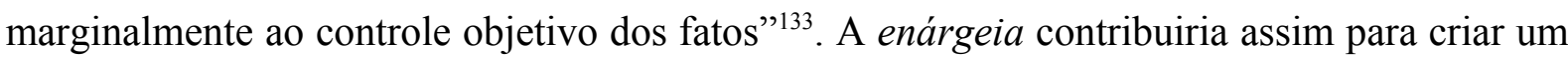
efeito de evidência e de verossimilhança no discurso histórico. Mas não seria ela um procedimento que faz o mesmo na Poesia? Tanto a ficção como a historiografia antiga tem como meta a verossimilhança (semelhança com a realidade), e seu sucesso era medido pelo grau em que a representação era perceptível pelo leitor, e por isso Luciano fala do historiador ideal como uma espécie de Fídias da História ${ }^{134}$. Em ambos os territórios a enárgeia coopera para a verossimilhança: se algo era possível de ser visto, poderia existir, mas não é o suficiente para ter existido. A historiografia, entretanto, alegará outros métodos para legitimar-se como verdadeira.

Falamos até o momento sobre a écfrase como parte integrante do efeito de verdade almejado pela historiografia, mas também ela pode cooperar em outros aspectos. Quando Plutarco nos diz que ela desperta emoções, podemos entender que a écfrase funciona muitas vezes como um argumento patético, integrado à linha de argumentação da obra. Tito Lívio, na descrição da batalha de Canas, faz uma descrição vívida da violência e crueldade cartaginesa e da devastação causada pela derrota romana. A cena desperta compaixão pelos sofrimentos dos romanos, e indignação contra os cartagineses. O despertar destas emoções persuade no sentido de considerar os cartagineses, e principalmente o general que ordenou a impiedosa matança, como cruéis e merecedores das futuras ações romanas contra eles. A écfrase não é assim uma digressão, e não apenas fonte de deleite, mas tem muitas vezes uma função clara argumentativa, tal qual a que a écfrase tinha no âmbito dos discursos oratórios. Assim, é uma amplificatio.

Mas as batalhas e lugares não são os únicos objetos da écfrase; ela pode também contribuir também para a construção de caracteres. Dionísio de Halicarnasso afirma que o orador Lísias em seus discurso, valendo-se da enárgeia, fazia com que os ouvintes vissem as ações que ele descrevia, como se estivessem face a face com os caracteres que agiam; era

\footnotetext{
${ }^{133}$ Ginzburg $(2007,24)$.

134 Cf. Walker (1993, 374). O estudioso afirma que ficção e fato parecem existir sem contradição na historiografia antiga (refere-se a Tucídides principalmente), e o grau de verossimilhança era justamente perceptível pelo grau de possibilidade de ver o que fora narrado, e assim o melhor historiador seria um Fídias da história como afirmara Luciano.
} 
excelente na caracterização (êthopeia) das emoções, qualidade morais e ações das personagens ${ }^{135}$. A construção de retratos pelos historiadores é comparada aos retratos de pintores e escultores: Cícero, na famosa carta a Luceio (Ad. Fam. 5,12), afirma que a descrição do espartano Agesilau feita por Xenofonte superou facilmente todos os retratos e todas as esculturas do mundo (par.7). Mas antes de analisarmos propriamente do uso da enárgeia na construção do êthos de Aníbal, tratemos brevemente do conceito de êthos entre alguns autores antigos.

\subsection{O êthos segundo Retóricas e Poéticas Antigas}

Neste subcapítulo, trataremos do conceito de êthos segundo alguns rétores e poetas gregos e latinos, principalmente Aristóteles, Horácio, e Cícero. Não abordaremos o sentido ontológico do termo, discutido amplamente por filósofos antigos, uma vez que estamos preocupados mais com a sua representação, embora saibamos que o sentido ontológico possui também desdobramentos e implicações no campo da retórica e poética. Variações de sentidos do conceito são encontradas nos retores gregos, que divergem em certa medida também dos oradores romanos, sobretudo Cícero.

Na teoria platônica, êthos define o espaço onde linguagem e verdade se encontram e são feitas encarnadas intimamente no indivíduo. Assim, o discurso do falante e seu caráter são inseparáveis ${ }^{136}$, o discurso é tal qual o caráter. Platão, nas suas obras, utiliza o termo no singular com o sentido de caráter moral, por oposição ao físico, e no plural com o sentido de costumes e hábitos ${ }^{137}$. Não há relação etimológica, entretanto, entre éthos, costume, e êthos,

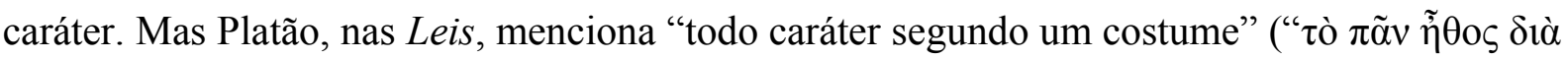
$\left.\varepsilon \varepsilon^{\circ} \varsigma{ }^{138}\right)$. Hábito e caráter parecem ser, assim, também inesperáveis para Platão.

\footnotetext{
${ }^{135}$ D. H. Lys. 7-8. : "Vividness [enárgeian] is a quality which the style of Lysias has in abundance. This consists in a certain power he has of conveying the things he is describing to the senses of his audience, and its arises out of his grasp of circumstantial detail. Nobody who applies his mind to the speeches of Lysias will be so obtuse, insensitive or slow-witted that he will no feel that he can see the actions which are being described going on and that he is meeting face-to-face the characters in the orator's story. And he will require no further evidence of the likely actions, feelings, thoughts or words of different persons. He was the best of all the orators at observing human nature and ascribing to each type of person the appropriate emotions, moral qualities and actions. I also ascribe to Lysias that most pleasing quality, which is generally called characterisation [ēthopoiían]" (Traução de S. Usher, 2000).

${ }^{136}$ Cf. Baumlin (2001, 236-277).

${ }^{137}$ Cf. Martins (2009, 42).

${ }^{138}$ Platão, Leis. In: Opera Omnia, 7, 792e, apud Martins $(2009,41)$.
} 
Isócrates, em Antídosis, apesar de afirmar que a arte não é capaz de conferir honestidade e justiça à naturezas depravadas, reconhece que a vontade de falar bem pode tornar alguém melhor e mais digno (Antídosis. 337). Segundo Isócrates, o orador devia ter um caráter bom e preocupar-se com sua reputação (Antídosis, 278). Dionísio de Halicarnaso conta que o orador Lísias tinha uma habilidade notável em construir provas a partir do caráter, e frequentemente o fazia acreditar no caráter bom de seu cliente descrevendo as circunstâncias de sua vida e de seus familiares, suas ações passadas e seus princípios. Entretanto, quando os fatos não ajudam, Lísias fazia com que os clientes parecessem honestos a partir do discurso ( D.H., Lys. 19.3-4).

Para Aristóteles, entretanto, bastava apenas que o orador parecesse bom e honesto. $\mathrm{O}$ termo êthos ocorre nas diversas obras de Aristóteles com diferentes nuances de sentidos conforme o objetivo da obra, e às vezes até mesmo em uma única é utilizado com um sentido mais estrito e ora mais geral. Na Retórica, o êthos é tratado como um aspecto da invenção, e é, juntamente com o lógos e páthos, uma prova artística.

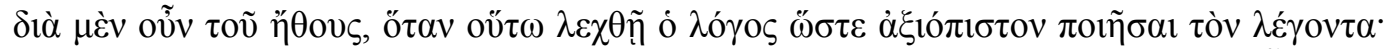

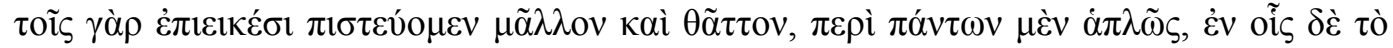

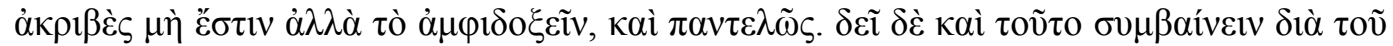

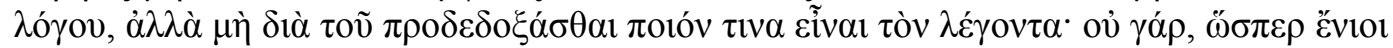

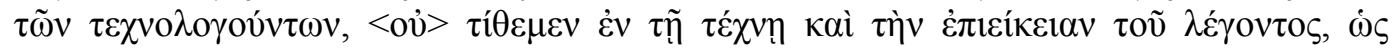

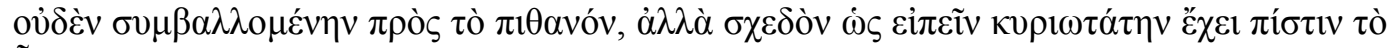
$\tilde{\eta} \theta$ os. (Arist. Rh. 1356a).

Persuade-se pelo caráter quando o discurso é proferido de tal maneira que deixa a impressão de o orador ser digno de fé. Pois acreditamos mais e bem mais depressa em pessoas honestas, em todas as coisas em geral, mas sobretudo nas de que não há conhecimento exacto e que deixam margem para a dúvida. É, porém, necessário que essa confiança seja resultado do discurso e não de uma opinião prévia sobre o caráter; pois não se deve considerar sem importância para a persuasão a probidade do que fala, como aliás alguns autores desta arte propõem, mas quase se poderia dizer que o caráter é o principal meio de persuasão ${ }^{139}$.

Para Aristóteles, neste trecho, o êthos é construído apenas pelo discursar, trata-se de uma imagem de si criada intradiscursivamente, sem a influência da reputação prévia do orador; e é o êthos o elemento do discurso que apresenta o orador como digno de fé. Em outro trecho, Aristóteles diz que o orador que pareça ter prudência, virtude e benevolência, é persuasivo, sem necessidade de demonstrações (Rh.1378a6-19). Aristóteles, assim, parece contrariar, pois, Isócrates, para quem a vida de um homem tem mais peso que as suas palavras (Antídosis, 339). Entretanto, esta é a visão aristotélica depreendida da leitura dos dois primeiros livros da Retórica. No livro terceiro, capítulo primeiro, Aristóteles restringe à

\footnotetext{
${ }^{139}$ Arist. Rh. 1356a. Tradução de M. Alexandre Júnior, P. F. Alberto e A. N. Pena.
} 
argumentação a qualidade de prova artística. Parece-nos, portanto, que, para o estagirita, se o caráter for fruto do discurso, trata-se de uma prova artística, entretanto, se o êthos de um orador for fruto de sua reputação, algo que, portanto, precede o discurso, trata-se de um meio de persuasão inartístico.

Tendo em vista que o êthos discursivo segundo a Retórica emerge do discurso, Aristóteles oferece ao leitor, nos capítulos 12 a 17 do livro 2, uma lista de tipos de caracteres, diferentes êthê para que o orador possa adequar-se aos variados tipos de audiência. Em 1389a3, Aristóteles fala sobre os êthê dos jovens, e em 1389b13 os compara ao dos idosos, sendo que os oradores devem servir-se de discursos adequados a tais êthê para assumir tais aparências (1390a24-7). O peripatético fala ainda sobre caráter dos que estão no auge da vida, dos nobres, dos ricos, dos poderosos, utilizando sempre o termo êthos. Parece que Aristóteles está descrevendo tipos, ao modo do que faz Teofrasto em Os caracteres. Segundo Blundell, os diferentes tipos de êthê, com suas características, estão catalogados em detalhes, para ajudar o falante a acomodar as palavras a eles. Se alguém utiliza os 'sinais' apropriados, a narrativa terá êthos ${ }^{140}$.

Wisse $^{141}$ ressalta que na Retórica o êthos abrange qualidades morais e intelectuais, ao contrário do que propõe o próprio Aristóteles na Ethica Nicomachea, onde o termo designa apenas a soma de qualidades morais, por oposição a diánoia ("faculdade de pensar"). $\mathrm{Na}$ Poética, êthos indica também a totalidade das qualidades morais e intelectuais ${ }^{142}$. É neste sentido mais amplo que Aristóteles parece utilizar o termo quando diz que tratará dos tipos de caracteres (êthê), segundo as paixões, os hábitos, idades e fortuna (Rh.1388b31-32). Uma vez que se faz necessário ao orador adequar-se a cada audiência e simular determinados caracteres, são importantes também características mais gerais que acompanham cada êthos, como o andar do indivíduo. Aristóteles diz: "Outros elementos que exprimem os traços morais são os que correspondem a cada um dos caracteres. Por exemplo, "ao mesmo tempo que falava, pôs-se a andar": isso mostra claramente arrogância e rudeza de carácter". (Rh. 1417a 21). Tal concepção parece demonstrar que existem sinais, características e comportamentos que são tidos por uma sociedade (conforme suas convenções) como própria de um determinado caráter.

\footnotetext{
${ }^{140}$ Blundell $(1992,165)$.

${ }^{141}$ Wisse $(1989,30-1)$.

${ }^{142}$ Cf. Blundell $(1992,162)$.
} 
Parece claro que êthos discursivo é a noção que o orador apresenta de si, e que é um meio de persuasão, mas seria ela apenas construída pelo discurso, como predominantemente expôs Aristóteles na Retórica, ou elementos extradiscursivos, provas atécnicas também influenciariam nesta concepção, tal como de certa maneira já havia apontado Isócrates? O orador Cícero complementa esta discussão no contexto romano, demonstrando como elementos intra e extradiscursivos interagem entre si para a composição do êthos. Assim como Aristóteles, Cícero, no De Oratore, não restringe o êthos apenas à parte do discurso do exórdio, como fazem os manuais de retórica (Retórica a Herênio e Retórica a Alexandre). Cícero parece adotar o sistema aristotélico dos três modos de persuasão (lógos, êthos e páthos):

Ita omnis ratio dicendi tribus ad persuadendum rebus est nixa: ut probemus vera esse, quae defendimus; ut conciliemus eos nobis, qui audiunt; ut animos eorum, ad quemcumque causa postulabit motum, vocemus.

Dessa forma, todo o método do discurso está ligado a três elementos para que se atinja a persuasão: provar ser verdadeiro o que defendemos, cativar os ouvintes, provocar em seus ânimos qualquer emoção que a causa exige. ${ }^{143}$

Mas a concepção de êthos ciceroniana, o "cativar os ouvintes", difere do entendimento aristotélico de prova apenas artística:

Valet igitur multum ad vincendum probari mores et instituta et facta et vitam eorum, qui agent causas, et eorum, pro quibus, et item improbari adversariorum, animosque eorum, apud quos agetur, conciliari quam maxime ad benevolentiam cum erga oratorem tum erga illum, pro quo dicet orator. Conciliantur autem animi dignitate hominis, rebus gestis, existimatione vitae; quae facilius ornari possunt, si modo sunt, quam fingi, si nulla sunt. Sed haec adiuvant in oratore: lenitas vocis, vultus pudoris significatio, verborum comitas; si quid persequare acrius, ut invitus et coactus facere videare. Facilitatis, liberalitatis, mansuetudinis, pietatis, grati animi, non appetentis, non avidi signa proferre perutile est; eaque omnia, quae proborum, demissorum, non acrium, non pertinacium? non litigiosorum, non acerborum sunt, valde benevolentiam conciliant abalienantque $\mathrm{ab}$ eis, in quibus haec non sunt; itaque eadem sunt in adversarios ex contrario conferenda. Sed genus hoc totum orationis in eis causis excellit, in quibus minus potest inflammari animus iudicis acri et vehementi quadam incitatione; non enim semper fortis oratio quaeritur, sed saepe placida, summissa, lenis, quae maxime commendat reos. Reos autem appello non eos modo, qui arguuntur, sed omnis, quorum de re disceptatur; sic enim olim loquebantur. Horum igitur exprimere mores oratione iustos, integros, religiosos, timidos, perferentis iniuriarum mirum quiddam valet; et hoc vel in principiis vel in re narranda vel in perorando tantam habet vim, si est suaviter et cum sensu tractatum, ut saepe plus quam causa valeat. Tantum autem efficitur sensu quodam ac ratione dicendi, ut quasi mores oratoris effingat oratio; genere enim quodam sententiarum et genere verborum, adhibita etiam actione leni facilitatemque significante efficitur, ut probi, ut bene morati, ut boni viri esse videamur.

Tem muita força, então, para a vitória, que se aprovem o caráter, os costumes, os feitos e a vida dos que defendem as causas e daqueles em favor de quem as defendem, e, do

\footnotetext{
${ }^{143}$ Cic. De Orat. 2.115. Tradução de Adriano Scatolin.
} 
mesmo modo, que se desaprovem os dos adversários, bem como que se conduzem os ânimos daqueles perante os quais se discursa à benevolência tanto em relação ao orador como em relação ao que é defendido pelo orador. Cativam-se os ânimos pela dignidade do homem, por seus feitos, por sua reputação; pode-se orná-los com maior facilidade, se todavia existem, do que forjá-los, se absolutamente não existem. Ora, são vantajosos, no orador, a brandura da voz, a expressão de pudor no rosto, a afabilidade nas palavras e, se acaso fazes alguma reivindicação com maior rispidez, parecer fazê-lo contrariado e por obrigação. Exibir sinais de afabilidade, generosidade, brandura, devoção e de um ânimo grato, não ambicioso, não avaro, é extremamente útil; e tudo aquilo que é próprio de homens honestos, modestos, não de homens severos, obstinados, contenciosos, hostis, granjeia enormemente a benevolência e a afasta daqueles em quem tais elementos não estão presentes; sendo assim, esses mesmos elementos devem ser lançados contra os adversários de maneira inversa. Mas todo este gênero do discurso sobressai-se nas causas em que há menor possibilidade de se inflamar o ânimo do juiz por meio de uma instigação severa e veemente; é que nem sempre se busca um discurso vigoroso mas, muitas vezes, um discurso calmo, simples, brando, o qual recomenda sobremaneira os réus. Chamo de réus não apenas àqueles que são acusados, mas a todos os envolvidos na causa em questão, pois assim eram chamados antigamente. Apresentar o seu caráter pelo discurso, então, como justo, íntegro, religioso, timorato, tolerador de injustiças, tem um poder absolutamente admirável; e isso, quer no princípio, quer na narração da causa, quer no final, tem tamanha força, se for tratado com delicadeza e julgamento, que muitas vezes tem mais poder do que a causa. Realiza-se tanto por determinado julgamento e método oratórios, que se forja, por assim dizer, o caráter do orador; por meio de determinado tipo de pensamentos e determinado tipo de palavras, empregando-se ainda uma atuação branda e que expresse afabilidade, consegue-se que pareçamos homens honestos, de boa índole, bons. ${ }^{144}$

A personagem do diálogo Do Orador afirma que os ânimos são cativados tanto pela dignidade do homem, quanto por seus feitos e reputação. Em seguida, afirma que o discurso “orna' mais facilmente uma qualidade quanto ela existe do que quando não existe. Fica implícito, pois, que um caráter pode ser (mais dificilmente, entretanto) forjado apenas pelo discurso. Assim, o trecho parece defender que há uma interação entre aquilo que é construído pelo discurso e aquilo que lhe é exterior, a reputação e os feitos. A reputação, a vida do orador, seus costumes e feitos cooperam para a construção de um êthos persuasivo, que cative a benevolência. No discurso, o orador deve manipular tais elementos, ou forjar o caráter do orador, tanto pela invenção (pensamentos), quanto pela elocução, e pela actio.

Modernamente, a noção de êthos discursivo foi amplamente explorada pelos estudiosos da Análise do Discurso. Dominique Maingueneau, embora concorde com algumas facetas da noção de êthos segundo a Retórica de Aristóteles, apresenta uma visão mais

${ }^{144}$ Cic. De Orat. 2.182-4. Tradução de Adriano Scatolin. 
próxima da do orador Cícero. Apresentamos, pois, esta abordagem moderna para lançar luz à interação entre elementos intra e extradiscursivos que Cícero parece sugerir.

Maingueneau propõe que, embora se constitua por meio do discurso, "O ethos é uma noção fundamentalmente híbrida (sociodiscursiva), um comportamento socialmente avaliado, que não pode ser apreendido fora de uma situação de comunicação precisa, ela própria integrada a uma conjuntura sócio-histórica determinada" ${ }^{145}$. O êthos nesta perspectiva não é apenas um meio de persuasão, mas é parte da cena de enunciação. Para o estudioso, o êthos não recobre apenas a dimensão verbal, mas também o conjunto de determinações físicas e psíquicas associadas ao falante pelas representações coletivas. Trata-se da soma da dimensão verbal com o "caráter" (conjunto de traços psicológicos) e a "corporalidade" (traços físicos e indumentários). E ainda, segundo o autor, o êthos implica ainda "uma forma de mover-se no espaço social, uma disciplina tácita do corpo, apreendida por meio de um comportamento. $\mathrm{O}$ destinatário o identifica apoiando-se em um conjunto difuso de representações sociais, avaliadas positivamente ou negativamente, de estereótipos, que a enunciação contribui para reforçar ou transformar" ${ }^{146}$. Nessa visão, tanto caráter quanto corporalidade, inseparáveis, estão apoiados em estereótipos, valorizados ou desvalorizados pela coletividade em que se produz a enunciação. E o destinatário, inserido no "mundo ético" do enunciador, é capaz de considerar uma característica ou um traço como próprio de um tipo de êthos. Neste sentido, um traço físico, uma vestimenta, um modo de comportamento de um enunciador são identificados como próprios de um tipo de êthos. Parece claro, portanto, que há uma convenção de estereótipos e coletividade delimitada por um espaço e tempo. E esta ideia, claramente, como vimos, já estava presente entre os antigos. Por exemplo, quando Aristóteles fala sobre os êthê de cada idade, ou quando diz que o andar rápido é próprio de tal êthos, ou se pensarmos ainda nos Caracteres, de Teofrasto. Contudo, não estamos afirmando que o êthos efetivo é um tipo, estereotipado, mas sim que tanto na construção do êthos quanto na sua recepção, estão envolvidos traços convencionados, identificados como próprios de um tipo de caráter. Caracteres mais complexos podem ser criador manipulando-se características de estereótipos.

Passando de uma concepção de êthos discursivo, do orador, para o da personagem dramática, é natural que as ações da personagem, dispostas diante dos olhos do espectador,

\footnotetext{
${ }^{145}$ Maingueneau $(2008,62)$.

${ }^{146}$ Maingueneau $(2008,65)$.
} 
tenham grande importância na construção do caráter. Na Poética, Aristóteles fala do êthos, principalmente do agente da Tragédia:

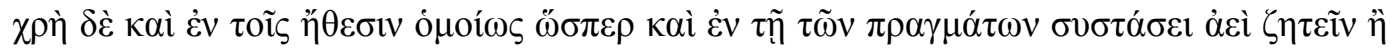

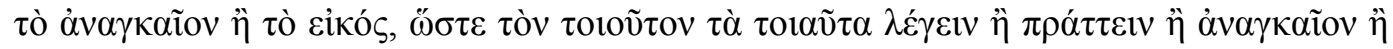

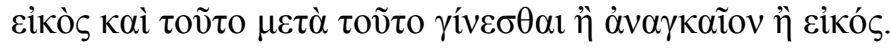

Tanto na representação dos caracteres como no entrecho das ações, importa procurar sempre a verossimilhança e a necessidade; por isso, as palavras e os atos de uma personagem de certo caráter devem justificar-se por sua verossimilhança e necessidade, tal como nos mitos os sucessos de ação para ação. ${ }^{147}$

As personagens devem ser representados e agir de acordo com aquilo que é provável (eikós) e necessário (anankaîon) segundo seu caráter. Um pouco antes, Aristóteles já havia dito que havia caráter quando as palavras e ações derem a conhecer alguma propensão (Po. 1454a17-19). Assim, o êthos de uma pessoa cria uma expectativa da maneira de comportamento em determinadas circunstâncias. Para que haja uma expectativa com relação ao comportamento de um caráter, é necessário que ele seja construído com base em representações convencionadas pela recepção. Assim, é necessário que haja também uma convenção de que um determinado tipo de agir é próprio de uma determinado tipo de caráter. E para representar, o poeta parte então destas convenções e paradigmas, e não da realidade.

Horácio também fala da adequação da representação da personagem à expectativas da recepção, mas, neste caso, não com relação a tipos de caráter, mas sim à fama de caracteres já conhecidos:

Aut famam sequere aut sibi conuenientia finge scriptor. Honoratum si forte reponis Achillem, impiger, iracundus, inexorabilis, acer iura neget sibi nata, nihil non arroget armis. Sit Medea ferox inuitaque, flebilis Ino, perfidus Ixion, Io uaga, tristis Orestes. Siquid inexpertum scanae committis et audes personam formare nouam, seruetur ad imum qualis ab incepto precesserit et sibi constet.

Segue, ó escritor, a tradição ou imagina caracteres bem apropriados: se acaso repuseres em cena o glorioso Aquiles, fá-lo activo, colérico, inexorável e rude, que não adita terem sido criadas as leis também para ele e nada faça que não confie à força das armas. Que Medeia seja feroz e indomável, Ino chorosa, Ixíon pérfido, Io errante e Orestes triste. Mas se algo de original quiseres introduzir, ousando conceber em cena nova personagem, então que seja conservada até o fim como foi descrita de início e que seja coerente ${ }^{148}$.

\footnotetext{
${ }^{147}$ Arist. Po. 1454A33-36. Tradução de Eudoro de Souza.

${ }^{148}$ Hor. Ars. 119-127. Tradução de R. M. Rosado Fernandes.
} 
Horácio trata, neste trecho, da construção de êthê famosos, personagens já conhecidas na literatura. $\mathrm{Na}$ apresentação destes caracteres, é preciso fazê-los com qualidades que a recepção espera que tenham, de acordo com a reputação prévia. Na construção desses êthê, portanto, fica clara a influência de um elemento pré-discursivo, a reputação. Mas se a personagem for nova, Horácio propõe que suas qualidades sejam as mesmas do início ao fim, estabelecendo assim a continuidade da expectativa com relação à personagem como coerência. Assim, o critério da verossimilhança é a expectativa, primeiro expectativa de como uma pessoa realmente é, e segundo de como é apropriado representá-la em um determinado gênero. ${ }^{149}$

Nos versos 156 a 178 da Arte Poética, Horácio trata dos caracteres, mores, que podem aparecer nos diversos gêneros dramáticos. À mesma maneira de Aristóteles e Teofrasto, Horácio elenca diferentes tipos de comportamento e qualidades de acordo com as diferentes idades. O poeta deve, portanto, ater-se às qualidades e atributos que são próprios de cada idade, ou melhor, que são tidos como próprios de cada idade pelas convenções de cada sociedade.

As ações, segundo Aristóteles na Poética, são determinadas pelo êthos, e isto é importante no desenvolvimento da trama. Na poesia, portanto, o êthos pode ser deduzido a partir das ações. Vejamos o trecho:

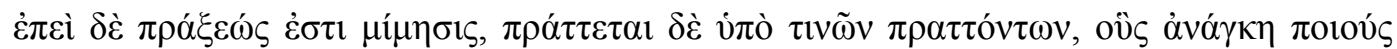

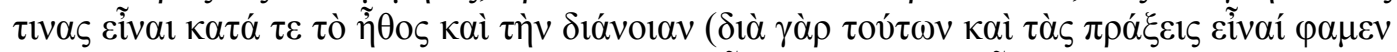

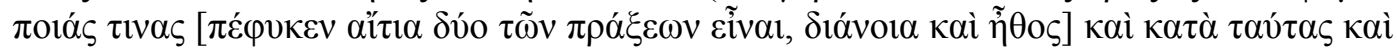

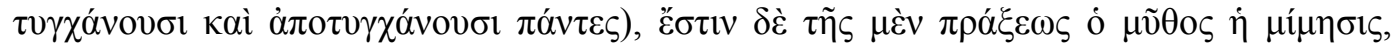

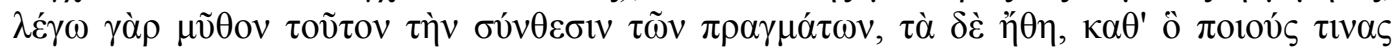

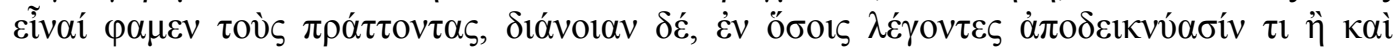

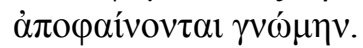

E como a tragédia é a imitação de uma ação e se executa mediante personagens que agem e que diversamente se apresentam, conforme o próprio caráter e pensamento (porque é segundo estas diferenças de caráter e pensamento que nós qualificamos as ações), daí vem por consequência o serem duas as causas naturais que determinam as ações: pensamento e caráter; e, nas ações [assim determinadas], tem origem a boa ou má fortuna dos homens. Ora o mito é imitação de ações; e por "mito" entendo a composição dos atos; por "caráter", o que nos faz dizer das personagens que elas têm tal ou tal qualidade; e por "pensamento", tudo quanto digam as personagens para demonstrar o quer que seja para manifestar sua decisão ${ }^{150}$.

O caráter é aquilo que nos faz dizer que uma personagem tem tal ou tal qualidade, sejam traços descritos ou ações. Este trecho é um pouco particular na Poética, por distinguir, à

\footnotetext{
${ }^{149}$ Cf. Levene (2010, 173).

${ }^{150}$ Arist. Po.1449b.36-1450a7. Tradução de E. Souza.
} 
maneira da Ética a Nicômaco, caráter e pensamento (diánoia), ou intelecto, dois aspectos do homem. Juntas, tais instancias são responsáveis pela decisão, prohaíresis, e consequentemente pelas ações ${ }^{151}$. Entretanto, quando Aristóteles aborda pela primeira vez o êthos ao tratar de quais caracteres, distintos pelas virtudes ou vícios, seriam adequados a quais gêneros poéticos (1448a1-4), não parece haver tal distinção de caráter e intelecto. Do ponto de vista externo, da recepção da representação, caráter e pensamento são indistinguíveis. Os dois juntos é que determinam uma decisão e a ação. Assim, esta diferenciação importa somente do ponto de vista ético, e não do retórico: o que é importante é como melhor representar um tipo de pessoa que se comportaria de certa maneira.

Parece claro até o momento que há em uma sociedade um nível de convenção de certos atributos, de comportamento, traços psicológicos e ações são próprios de alguns tipos de caráter. Assim, a construção do êthos ou do orador ou da personagem manipula tais estereótipos. Mas tais atributos englobariam também traços físicos? Vejamos o que Filóstrato, o Velho, em Eikones II.9.1, fala sobre o retrato de Panteia criado por Xenofonte:

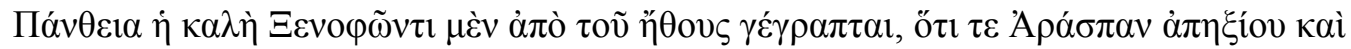

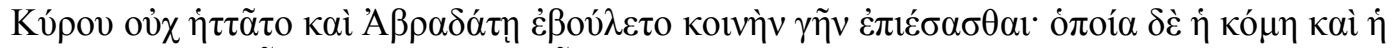

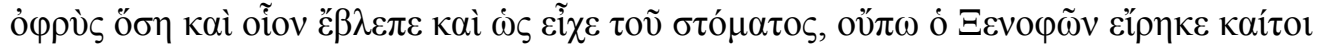

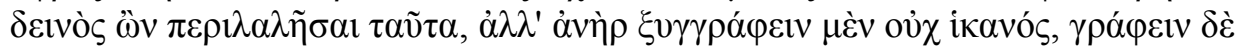

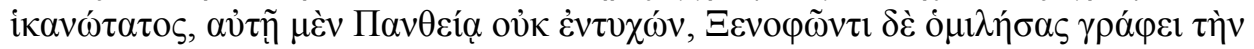

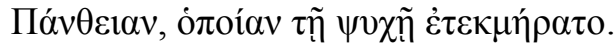

A bela Panteia foi descrita por Xenofonte de acordo com seu êthos, pois rejeitou Araspas e não cedeu a Ciro, e queria uma terra comum sobre ela e Abradates. Mas como eram os cabelos, a forma das sobrancelhas e o seu olhar, e a feição de sua boca, Xenofonte não disse, apesar de ser muito hábil em descrever essas coisas. Todavia, um homem sem habilidade na escrita, mas habilíssimo na pintura, que nunca encontrou Panteia em pessoa, mas conhecedor de Xenofonte, a pinta, conforme indícios que viu em sua alma ${ }^{152}$.

Filóstrato demonstra como Xenofonte em Anábase, na descrição de Panteia, faz uma descrição vívida de seu êthos, e tenta provocar a imaginação do leitor para criar uma phantasía de Panteia. Entretanto não há descrição de traços físicos, e o autor diz que seria possível pintá-la através dos indícios da alma. Luciano comenta também a retratação de Panteia por Xenofonte. Em Eikones, 10, a personagem do diálogo afirma que toda vez que lê o relato da Panteia de Xenofonte é como se ela estivesse diante dele, e que quase ouve sua voz a a proferir as palavras que o historiador pusera em sua boca e a vê armando e enviando seu

\footnotetext{
${ }^{151}$ Lucas in Aristóteles (2002, 107).

152 Philostr. Im. 2.9.1. Tradução cedida por Rosangela Santoro de Souza Amato.
} 
marido para a guerra ${ }^{153}$. Luciano, através de um retrato moral, vê diante de si uma Panteia física, e com traços de comportamento. Tais características parecem, portanto, interligadas. A ideia de que a partir de um retrato moral se pudesse depreender traços morais e vice-versa, estranha aos nossos olhos, talvez não o fosse tanto para os olhos dos antigos. Sabemos que existiram na Antiguidade estudos de Fisiognomia, cuja origem pode ter relação com a medicina antiga, e que investigavam a interdependência entre corpo e alma, a íntima relação entre traços morais e intelectuais e a aparência física. As fontes que nos restaram sobre este saber consistem em dois tratados sobre o assunto contidos no corpus aristotélico (a autoria é, entretanto, controversa), e ainda de um grupo de versões do tratado de Polemão, já do período do imperador Adriano. Há ainda um trabalho em língua latina, atribuído a Apuleio, que se diz ser uma compilação dos trabalhos do médico Lóxus, do filósofo Aristóteles e do rétor Polemão ${ }^{154}$. Entretanto, é muito difícil determinar a circulação e aceitação desta tradição naquela época. Mas sua existência nos aponta para a possibilidade de uma maior relação entre traços físicos e o caráter na Antiguidade. Se existia uma convenção de tipos de caráter, dentro das características identificadas como próprias de um tipo provavelmente estavam também traços físicos, e assim, o ouvinte ou leitor talvez pudesse imaginar certos traços físicos a partir de uma descrição moral ou intelectual, e vice-versa. Assim, a imitação tem por objeto não a realidade, mas um modelo na imaginação do autor, e a recepção também só pode apreciar o resultado desta imitação se tiver um modelo próximo em sua mente ${ }^{155}$.

Na Retórica a Herênio, a descrição física de maneira a identificar alguém foi chamada de effictio, efígie em língua latina (4.63), e a descrição da natureza de alguém pelos sinais distintivos que, como marcas, são atributos daquela natureza foi chamada de notatio (4.63). O manual as considera ornamentos das sentenças, mas não por isso dispensáveis, são justamente maneiras de construir caracteres. Se observarmos a preceituação de alguns manuais de retórica sobre os retratos no gênero epidítico, encontraremos algumas pistas sobre que qualidades eram observadas e consideradas importantes para a construção dos caracteres em Roma, e eram assim usadas para construir diferentes "tipos". Na Retórica a Herênio, o autor anônimo trata da inventio nas causas de elogio ou vitupério, e afirma que é necessário expor as virtudes do ânimo do retratado e depois demonstrar de que modo as vantagens e desvantagens do corpo ou das circunstâncias externas foram tratadas por tal ânimo (3.13).

\footnotetext{
${ }^{153}$ Luciano, Im. 10.

${ }^{154}$ Cf. Armstrong $(1985,52-3)$.

${ }^{155}$ Martins \& Amato $(2012,129)$.
} 
Então se preceitua que devem ser primeiro retratadas as circunstancias externas da ascendência e educação. Depois, as vantagens do corpo:

[...] natura si sit dignitas atque forma, laudei fuisse eam, non quemadmodum ceteris detrimento atque dedecori; si uires atque uelocitas egregia, honestis haec exercitationibus et industriis dicemus conparata; si ualetudo perpetua, dilingentia et temperantia cupiditatum; in uituperatione, si erunt haec corporis commoda, male his erunt, praeter formam omnia ipsius culpa et intemperantia afuisse dicemus.

[...] se tem beleza e proporção naturais, diremos que lhe serviram para o elogio e não, como em outros, para desonra e degradação; se é de força e velocidade excelentes, diremos que foram alcançadas com exercício e dedicação recomendáveis. Se tem boa saúde, deve-se ao cuidado de si e à moderação dos desejos. No vitupério, se existirem essas vantagens físicas, diremos que fez mau uso daquilo que, como qualquer gladiador, tem por natureza e acaso; se não existirem, diremos que carece não só de beleza, mas de todas as outras vantagens, por sua própria culpa e intemperança. ${ }^{156}$

O orador deve deduzir, ou criar, qualidades ou vícios a partir de características físicas, como atribuir a virtude da moderação à causa de ter boa saúde. Em seguida, o autor do manual preceitua que se deve tratar de outras circunstâncias externas para considerar os vícios e virtudes animi:

[...] diuitiae an paupertas fuerit, et quae potestas, quae gloriae, quae amicitiae, quae inimicitiae, et quid fortiter inimicitiis gerundis fecerit; cuius causa susceperit inimicitias; qua fide, beniuolentia, officio gesserit amicitias; in diuitiis qualis aut paupertate cuiusmodi fuerit; quemadmodum habuerit in potestatibus gerundis animum. Si interierit, cuismodi mors eius fuerit, cuiusmodi res morem eius sit consecuta. Ad omens autem res, in quibus animus hominis maxime consideratur, illae quattuor animi uirtutes erunt adcommodandae; ut, si laudemus, aliud iuste, aliud fortiter, aliud modeste, et aliud prudenter factum esse dicamus; si uituperabimus, aliud iniuste, alius inmodeste, aliud ignaue, alius stulte factum praediceums.

"Foi rico ou pobre? Com que poder, que glória, que amizades e inimizades? O que fez corajosamente para gerar inimizades? Com que fé, benevolência e dever conduziu suas amizades? Que tipo de homem foi na riqueza e na pobreza? Com que tipo de ânimo exerceu o poder? Se já morreu, que tipo de morte teve e com que consequências? A todas as outras coisas para as quais se considera principalmente o ânimo do homem, devem-se acomodar aquelas quatro virtudes, de modo que, se elogiarmos, diremos que uma coisa foi feita com justiça, outra com coragem, outra com modéstia, outra com prudência; se vituperarmos, proclamaremos que uma coisa se fez injusta, outra imodesta, outra covarde, outra imprudentemente. ${ }^{157}$

A preceituação do autor do manual reflete parte da configuração social, dos valores de sua época, e parte daquilo que era aprovado ou reprovado, tido como positivo ou negativo pelos cidadãos. As virtudes da justiça, coragem, modéstia e prudência são de suma importância neste período em Roma, e por isso são elas a expostas através das ações descritas. Anteriormente, entretanto, aos traços morais, o caráter é construído pela posição política do

\footnotetext{
${ }^{156}$ Rhet. Her. 3.14. Tradução de A. P. C. Faria e A. Seabra.

${ }^{157}$ Rhet. Her. 3.14-15. Tradução de A. P. C. Faria e A. Seabra.
} 
indivíduo na sociedade. A origem de um homem já dizia sobre seu êthos, que era praticamente "herdado" (importa, principalmente no período republicano, se o indivíduo é de família nobre, ou se é filho de escravos etc), bem a como a posição ou cargo do indivíduo na cidade. O discurso epidítico, assim, é construído com base naquilo que era identificado como digno, indigno, importante, no imaginário da sociedade. A construção do retrato parte, assim deste filtro que diz o que deve ser observado e dito para construir um elogio ou um vitupério. Como veremos, no retrato de Aníbal estão presentes alguns elemento desta ordem de descrição.

Ainda outra nuance de sentido pode ser atribuída ao termo êthos na Poética, quando Aristóteles propõe uma aproximação entre pintura e poesia: o filósofo afirma que assim como há tragédias de caracteres e sem caracteres, assim também é a pintura de Polignoto e Zêuxis (Po. 1461B, 12). Segundo Paulo Martins, depreende-se do texto aristotélico que Polignoto é um pintor de seres mimeticamente verossímeis (agathós êthográphos), enquanto a pintura de Zêuxis não tem caráter (graphé oudén ekhei êthos), ou seja, "é a pintura de seres perfeitos e indefectíveis, ou seja, sem características distintivas, mas igualmente aparentadas com o modelo, ou, ainda, seres tipificados como, por exemplo, as imagens forjadas para distinguir homens reconhecidos ou notáveis como aqueles que Plínio, o Velho proporá no livro 35, dos quais contudo, não se conhece a verdadeira aparência" ${ }^{158}$. Essa última, a pintura sem êthos, seria baseada na fictio, enquanto a primeira, a do êthográphos, reproduz o modelo tal qual ele se nos apresenta. Paulo Martins associa a pintura tal qual se nos apresenta para nós, a do ethográphos, a uma imagem histórica, e a pintura daquilo que poderia ser, fictio, à imagem poética $^{159}$. E na Poética, 1448a, Aristóteles afirma que os pintores imitam homens inferiores, superiores ou iguais a nós. Nesta partição, a presença de êthos indicaria um caráter oposto ao tipificado. Enfim, trata-se de uma abordagem interessante, que, contudo, não exploraremos a fundo nesta pesquisa. Dentro desta perspectiva, olhando para os retratos dos generais de Nepos e de Lívio, o de Nepos, como veremos, nos parece mais tipificado, e o de Lívio, por apresentar maior complexidade, vícios e virtudes, parece ser de um êthos mais de um homem como nós, superior em alguns momentos e inferior em outros, já que o retrato é sempre ambíguo.

Até então, vimos que o êthos, caráter que emerge pela linguagem, pode ser criado discursivamente, e também com a interação de elementos extradiscursivos, e neste processo

\footnotetext{
${ }^{158}$ Martins $(2011,92)$.

${ }^{159}$ Cf. Martins $(2011,93)$.
} 
importam traços de comportamento, psicológicos, e as ações, que são convencionadas socialmente como próprios de um tipo de caráter. Como vimos, a reputação de um orador interage com o discurso, e na Poesia a reputação de uma personagem importa na criação da verossimilhança. A reputação de Aníbal, a fama da pessoa histórica que havia sido passada de geração a geração e pela tradição historiográfica anterior, importará à construção de seu êthos por Tito Lívio, mas é no discurso que o historiador modificará ou ratificará tal reputação, através de descrições do seu caráter, de seu agir, e do discursos dramáticos, nos quais é possível analisar o êthos de Aníbal enquanto orador. E é através da narrativa, seu discurso, que o historiador o fará verossímil, pois para Lívio esta é a medida do verdadeiro.

\subsection{As personagens de Tito Lívio}

Bernard, em seu estudo Le portrait chez Tite-Live ${ }^{160}$, analisa cuidadosamente a composição dos caracteres em Tito Lívio, buscando demonstrar que algumas personagens são retratadas com maior complexidade do que propunham alguns estudiosos, que afirmavam, a partir de descrições diretas na obra, que os caracteres do historiador são estereotipados. De fato, se as compararmos com as personagens modernas, de profundidade psíquica, as personagens de Lívio parecerão superficiais.

Levene, entretanto, sugere que até para os padrões antigos a caracterização de Lívio estava aquém no que diz respeito a características de "personalidade". Para o estudioso, são raras as personagens com complexidade e desenvolvimento, e se as compararmos com as personagens de Tácito, são também menos dimensionais ${ }^{161}$. Entretanto, ele mesmo reconhece, ao buscar entender a partir da teoria retórica como os caracteres deveriam ser construídos, que o estereotipar era mais aceito na antiguidade do que hoje. Analisando o trecho 5.10.23-27 da Intitutio Oratoria de Quintiliano, Levene aponta que os romanos tinham a inserção da pessoa no quadro social como o principal fator determinante de seu caráter (expectativa de que, tendência de que um povo aja conforme os seus costumes, que os filhos ajam iguais os pais etc). Lívio então faz seu caracteres se inclinarem a tais padrões repetidos, principalmente se o foco são relações sociais (comandante militares e líderes políticos) ${ }^{162}$. Assim, ao historiador romano, o principal traço que caracteriza uma pessoal pode ser sua posição social, suas ações

\footnotetext{
${ }^{160}$ Bernard (2000).

${ }^{161}$ Levene (2010, 165-6; 174).

162 Levene (2010, 175-7).
} 
no âmbito público. Mas, como veremos, para Lívio, vícios e virtudes morais influenciam também nas decisões e ações públicas.

Aos olhos do leitor moderno as personagens de Tito Lívio podem parecer pouco complexas, pois o foco do historiador é externo, em julgamentos morais mais baseados em uma análise "objetiva" do que num envolvimento subjetivo no psicológico do indivíduo ${ }^{163}$. No entanto, como demonstra Bernard, a individualidade de alguns caracteres emerge de uma série de episódios nos quais o caráter é visto a partir de diferentes pontos de vista e representado por uma variedade de sentidos ${ }^{164}$. Veremos que o caráter de Aníbal torna-se complexo se considerarmos a multiplicidade das vozes no texto. Entretanto, personagens tipos são predominantes na obra, e normalmente estão inseridas no esquema de causalidade moral da história.

As mudanças que ocorrem com algumas personagens, e como veremos, também parece haver algumas aparentes contradições entre as algumas descrições de Aníbal e o seu agir, chegam a beirar a quebra de expectativa da qual fala Horácio na Arte Poética. Entretanto, lembramos aqui de que não estamos diante de uma personagem poética, mas de uma figura histórica, e que talvez a fama deste caráter valide tais contradições. Mas como veremos, as contradições em sua maioria aparecerão modalizadas na narrativa, constituindose mais ambiguidades do que propriamente contradições. Como afirmou Levene, mais do que tentar extrair uma personalidade singular a partir das caracterizações de Lívio, é preciso ver cada carácter de acordo com os papeis que ela executa no sistema dinâmico de interações com outros caracteres e mais amplamente contra o progresso da guerra como um todo ${ }^{165}$. Uma vez que o caráter do indivíduo está ligado aos rumos dos acontecimentos, é preciso moldá-lo ao sistema causal, e o caráter parece assim variar conforme a Fortuna da personagem. Tudo isso ficará mais claro quando tratarmos propriamente do êthos de Aníbal na Terceira Década.

\footnotetext{
${ }^{163}$ Bernard (2000, 256).

${ }^{164}$ Cf. Bernard (2000, 33-56).

165 Levene $(2010,186)$.
} 


\section{TITO LÍVIO E O ÊTHOS DE ANÍBAL}

\subsection{O monumento de Tito Lívio}

No primeiro parágrafo de seu Prefácio, Tito Lívio delimita o objeto de seu relato ao indagar se receberia a recompensa do trabalho se registrasse a história do povo romano desde os primórdios da Cidade (Facturusne operae pretium sim si a primórdio Vrbis res Populi perscripserim nec satis scio...). Os feitos do povo romano desde a fundação de Roma são a matéria da História de Lívio. Embora se dedique ao passado longínquo e às origens da cidade até a época contemporânea, a obra não pode ser considerada uma história universal geograficamente ${ }^{166}$.

Tito Lívio claramente vê a história romana em termos de declínio; o historiador contrasta no Prefácio o passado grandioso de Roma com um presente em que a cidade sofre pela sua grandeza $(\S 4)$, presencia muitos males (§5) e vive uma degeneração de costumes, de maneira não pode mais suportar nem seus vícios nem seus remédios (§9), e deixou-se penetrar, ainda que tardiamente, pela cobiça e luxúria (§11). Lívio não especifica precisamente no prefácio a causa do declínio romano, mas os estudiosos parecem concordar que os males do presente aos que se refere o historiador são as guerras civis ${ }^{167}$. É normalmente aceito que Lívio começou a escrever sua obra de 142 volumes por volta de 20 a. C, mas alguns estudiosos observam que o Prefácio deve ter sido escrito após 28 a. C, pois associam termo remedia da cláusula "quibus nec vitia mostra ne remedia pati possumus" ("estes tempos, em que não podemos suportar nem os nossos vícios nem os seus remédios, §9), à legislação de Augusto de 28a.c., com a qual o imperador alegava remediar a degeneração moral pública e privada ${ }^{168}$.Woodman ressalta que em outros momentos da História Romana a metáfora do remedium é utilizada pelo autor, justamente quando um ditador é nomeado para resolver alguma crise ${ }^{169}$. Entretanto, Moles ${ }^{170}$, autor de artigo de referencia sobre o Prefácio de Tito Lívio, observa que a historicidade desta Legislação já foi também questionada e, se excluída esta possibilidade, remedium referir-se-ia apenas ao governo de ditadura.

\footnotetext{
166 Cf. K. Clarke, Universal perspectives in Historiography, In: Kraus (1999, 251).

${ }^{167}$ Cf. Woodman $(1988,132)$.

168 Idem.

${ }^{169}$ Cf. Liv. 3.20.8; 22.8.5; Woodman (1988, 133).

170 Moles (2009, 68-9).
} 
Mas o escrever história, para o historiador, a rememoração dos tempos primitivos, tem o poder de afastar o historiador da visão dos males de sua época. É o que Lívio expressa no parágrafo quinto do Prefácio. Assim, a dedicação ao passado funciona como um remédio temporário. Mas a história parece ser para Lívio remédio também por instituir-se como fornecedora de exemplos, como aponta o parágrafo 10 do Prefácio:

Hoc illud est praecipue in cognitione rerum salubre ac frugiferum, omnis te exempli documenta in inlustri posita monumento intueri; inde tibi tuaeque rei publicae quod imitere capias, inde foedum inceptu foedum exitu quod uites. $(\S 10)$

O que é particularmente salutar e fecundo no conhecimento dos fatos é olhar atentamente as lições de cada exemplo, constantes de um documento claro: aí se pode encontrar o que imitar para si e para sua república aí, o que evitar - indigno pelo começo, indigno pelo desfecho. ${ }^{171}$

O historiador, neste trecho, caracteriza, como já havia feito no parágrafo $6^{172}$, sua história como um monumentum, que é duplamente a sua tarefa de conferir memória aos feitos do passado, e a própria obra Ab Vrbe Condita. Segundo Moles, o monumento tem dois aspectos: comemorar as conquistas das gerações passadas e advertir as gerações presentes e futuras ${ }^{173}$. E nota-se que o monumento a ser construído por Lívio é inlustris, claro e ilustre, lembrando-nos que história traz para a luz feitos que cairiam no esquecimento, e confere glória. Moles ressalta também que a tarefa do historiador iluminar, criar claridade e enargia. ${ }^{174}$ Há, neste processo um aspecto duplo: a verdade é uma questão de visão, o que pode ser visto pelo historiador ou o que foi visto por testemunhas confiáveis no passado e transmitido pela tradição histórica, mas também o aspecto da luz, clareza, visão despertada no leitor. Segundo o estudioso, Lívio imita aqui Tucídides ao aplicar o processo de skopeîn tanto a si quanto ao leitor.

Andrew Feldherr, em Spectacle and Society in Livy's History, observa que adjetivo inlustris é utilizado, em Cícero, por exemplo, como um termo técnico para "dispor o evento diante dos olhos", e então o autor no seu trabalho compara as descrições de Lívio a um espetáculo, associando as funções políticas de um espetáculo público à narrativa de Lívio. Segundo Feldherr, Lívio, reproduzindo os eventos do passado visualmente, de uma forma que permite que a audiência responda como espectadora, o historiador apropria-se de um meio

\footnotetext{
${ }_{171}$ Liv., Praef. 10. Tradução A. C. M. Fonseca, A. A. Peterline, M. da G. Novak, In: Novak, Neri \& Peterlini (1999).

172 Moles $(2009,64)$ ressalta que com a distinção básica presente no Prefácio entre poeticae fabulae e incorrupta rerum gestarum monumenta (\$6) Lívio invoca a Tucídides - na distinção entre mito/poesia e história (Thuc. 1.21.2, 1.22.4)- e à Heródoto, na recusa de julgar as fabulae, filiando assim sua própria história aos dois maiores historiadores. E ao conceituar sua obra como incorrupta rerum gestarum monumenta Lívio ecoa de certa maneira também o Prefácio de Heródoto, que propõe um relato imortal, e a reivindicação de Tucídides

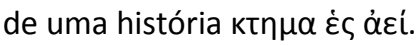

${ }^{173}$ Moles $(2009,72)$.

${ }^{174}$ Cf. Moles $(2009,74)$.
} 
crucial de participação política na cultura romana (como um triunfo, por exemplo), fazendo de sua obra um monumento a ser contemplado ${ }^{175}$.

Outro termo chave no parágrafo 10 do prefácio liviano é documenta. No monumento das res gestae estão contidos ensinamentos (documenta), que fornecem paradigmas de comportamento. Já no parágrafo 9, Lívio apresentara sua visão de como os acontecimentos dependem dos indivíduos:

[...] ad illa mihi pro se quisque acriter intendat aninum, quar vita, qui mores fuerint, per quos vírus quibusque artibus domi militiaeque et partum et auctum Imperium sit.

[...] penso que cada um, por si mesmo, deve interessar-se ardentemente por aquilo que foi a vida, que foram os costumes, que foram os homens através dos quais, e as artes pelas quais, na paz e na guerra, foi o Império criado e dilatado" 176 .

A concepção histórica de Tito Lívio é individual e moral; o destino dos acontecimentos, de um modo geral, depende das virtudes e vícios dos homens ilustres ${ }^{177}$. A Fortuna, para Lívio, costuma favorecer os virtuosos: ergo fortuna, ut saepe alias, virtutem est secuta $^{178}$. Segundo Luce, a explicação dos sucessos estão ligadas mais ao valores dos agentes da narrativa, não simplesmente o que foi feito por cada um, mas em que estado de espírito foi feito, do que às instituições, como a constituição romana, por exemplo, como acontece em Políbio $^{179}$. Segundo Sebastiani, a avaliação que Lívio faz dos acontecimentos parte de uma visão moral aristocrática:

Mais do que conservadora, a preocupação em avaliar comportamentos e situações tendo por referência o mos maiorum evidencia uma visão de mundo aristocrática. $\mathrm{O}$ vocabulário de homens como Tito Lívio está forjado por sua preocupação aristocrática com guerra e política. Eles interpretam o sucesso político e o fracasso inflexivelmente em termos morais. Reciprocamente, sua linguagem moral é essencialmente social e política. ${ }^{180 "}$.

Em ensaio sobre a construção paralela das figuras de Aníbal e Cipião Africano, Andreola Rossi demonstra como o sucesso da guerra para os cartagineses esteve aliado à disciplina de seu general; e como, no momento em que a disciplina cedeu lugar à luxúria e à amoenitas (durante a estadia em Cápua), iniciou-se a vitória dos romanos, mais virtuosos em disciplina. Para a autora, Aníbal e seus soldados passam por um processo de decadência moral, que os leva à derrota. Assim, Aníbal torna-se nesta fase exemplum do general sem sucesso $^{181}$. O êthos de Aníbal, dessa forma, é determinante do futuro do exército que ele

\footnotetext{
175 Feldherr $(1998,20)$.

${ }^{176}$ Liv. Praef. 9 Tradução de A. C. M. Fonseca, A. A. Peterline, M. da G. Novak. In: Novak, Neri \& Peterlini (1999).

${ }^{177}$ Cf. Allen $(1956,253)$.

${ }^{178}$ Liv. 4.37.

179 Luce $(1977,230-1)$.

${ }^{180}$ Sebastiani $(2006,307-8)$.

${ }^{181}$ Rossi $(2004,371)$.
} 
governa e ainda do destino de Cartago. Assim, a construção da persona histórica é fundamental para a relação de causa e efeito que rege o curso dos acontecimentos, é diretamente ligada ao modo de interpretação que Lívio faz da História. Entretanto, devemos tomar cuidado com qualquer tipo de generalização em Tito Lívio; Jane Chaplin nos adverte sobre o problema de interpretar episódios isolados como exemplos na obra, já que a obra é imensa e variada. Levene ${ }^{182}$ observa que o tratamento de Lívio dado aos heróis romanos que contribuem para o sucesso da nação, não é acrítico: há muitas figuras romanas ambíguas. A obra é complexa no que diz respeito à caracterização das personagens, pois raramente ela se dá diretamente pela voz da autoridade do historiador.

A causalidade moral por trás dos acontecimentos em Lívio é, entretanto, uma maneira pela qual o autor explica e vê os rumos dos acontecimentos. Assim, tal característica é primeiramente cara à visão de mundo do autor no entendimento dos acontecimentos; mas pode também fornecer exemplos, e, assim, estar ligada à função didática da obra em segundo plano.

Em Livy's Exemplary History, Jane Chaplin analisa como exempla são usados frequentemente pelas próprias personagens, que, tendo aproveitado bem alguns modelos, têm boa Fortuna. Lívio com frequência considera, em seus comentários, sábio aquele que soube aproveitar um exemplo. Cipião, por exemplo, segue o exemplo de Aníbal em levar a guerra até o país do inimigo e acaba por superá-lo. Para a autora, em Tito Lívio une-se a tradição historiográfica grega, na qual o passado já era uma fonte de sabedoria, à tradição romana de culto ao passado, fortalecendo-se assim a importância dos exempla ${ }^{183}$. Segundo a autora, Políbio, perpetuando a tradição da história útil, já entendia o passado como exemplar, mas a maneira como Lívio apresenta exemplos, o tratamento de exemplos por personagens, não se assemelha a Políbio. A autora vê um provável antecedente do procedimento no discurso de César na Conjuração de Catilina de Salústio, mas de maneira diferente de como aparecem em Lívio $^{184}$. A dimensão e importância dos exempla são maiores em Lívio. E este projeto moral do historiador, de ensino por meio de monumentos exemplos, tem proximidade com projeto de Augusto.

É comumente aceito que Lívio discute questões do presente, e em algumas passagens demonstra aprovar práticas de Augusto e promover suas políticas ${ }^{185}$. Entretanto, Tito Lívio foi

\footnotetext{
${ }^{182}$ Levene, Roman Historiography in the Late Republic, 284-5. In: Marincola, ed. (2007).

${ }^{183}$ Chaplin $(2000,16)$.

${ }^{184}$ Chaplin (2000, 23-5).

${ }^{185}$ Cf. Syme (1960, 317, 463-64) e Petersen (1961, 440). Ver Walsh (1961, 10-14) contra tal ideia.
} 
chamado de pompeianus por Tácito ${ }^{186}$, por louvar Pompeu excessivamente. Tal atributo e ação não seria adequado para um simpatizante de Augusto. Tito Lívio discute sim questões de seu presente na obra, e propõe um ideal moral e de virtudes que se insere no projeto de restauração moral almejado por Augusto. Entretanto, em sua obra, ele também alerta que Roma não tolerará um rei absolutista ${ }^{187}$.

Inserida neste projeto de monumento educativo, o êthos e imago de Aníbal são também monumentos e exemplos daquilo que deve ser imitado ou evitado, tanto pelos outros personagens da obra, e assim se dá o contraste com Cipião, por exemplo, quanto pelo leitor da obra no presente e no futuro; leitor que, a partir do caráter construído da persona, não só entende o motivo dos rumos dos acontecimentos passados, mas pode valer-se de exemplos para imitar os acertos e desviar dos erros, evitando as consequências que tais ações tiveram no passado. No entanto, a caracterização de Aníbal, como veremos, é ambígua e complexa.

\subsection{O retrato ${ }^{188}$ do Aníbal jovem}

Buscamos selecionar na obra supérstite de Tito Lívio trechos importantes para a construção do êthos de Aníbal. Ao longo da análise, buscaremos verificar como Aníbal é caracterizado de maneira direta, seja por descrições de seu caráter pelo próprio historiador (como em 21.4), seja por écfrases de sua ações, nas descrições de sua força e estratégia nas grandes batalhas por exemplo, como Trébia, Trasimeno e Canas, e de maneira indireta, por outras vozes no texto. Muitas vezes Aníbal é pintado a partir de discursos de outras personagens, algumas vezes por sua própria fala, e também por relatos de outros historiadores, que o historiador apresenta como rumores não confirmados. Assim, a análise será pautada por esta variedade de vozes que surgem no texto, muitas vezes contraditórias, e o retrato de Aníbal parecerá às vezes ambíguo e multifacetado, como já é o retrato inicial feito pelo próprio historiador. Os trechos citados de Tito Lívio em língua latina serão reproduzidos a partir da edição da "Loeb Classical Library" (1970-1999), e todas as traduções são de nossa autoria.

A terceira década de Tito Lívio comporta os acontecimentos do início da segunda guerra púnica (que o próprio autor chama de a guerra mais memorável já empreendida, 21.1.1) e termina com a batalha de Zama, na qual os cartagineses são derrotados. Aníbal será,

\footnotetext{
${ }^{186}$ Tac. Ann. 4.34.

187 Petersen $(1961,451)$.

188 Utilizamos o termo "retrato" ao longo da Dissertação com o sentido geral, já corrente em nossa língua, de descrição dos traços físicos ou psicológicos de uma pessoa, seja essa uma descrição verbal ou pictórica. Originalmente, "ritràtto", do italiano, significava apenas o retrato pictórico humano, pintado ou esculpido.
} 
portanto, o grande protagonista do lado dos cartagineses nesses livros, e então grande ênfase ao general é dada no início do livro 21. Já no primeiro capítulo, Tito Lívio, após falar brevemente sobre a causa da guerra, relata o juramento que Aníbal fez quando tinha nove anos:

Fama est etiam Hannibalem annorum ferme novem pueriliter blandientem patri Hamilcari ut duceretur in Hispaniam, cum perfecto Africo bello exercitum eo traiecturus sacrificaret, altaribus admotum tactis sacris iure iurando adactum se cum primum posset hostem fore populo Romano (Liv. 21.1.4).

Conta-se também que, Aníbal, quando tinha aproximadamente nove anos, implorava ao pai, como fazem as crianças, que o levasse para a Hispânia. Terminada a guerra na África e prestes a mover o exército, Amílcar fez um sacrifício e conduziu Aníbal aos altares: tocando os sacrifícios, obrigou-o a prestar um juramento de que, o quanto antes, seria inimigo do povo romano ${ }^{189}$.

Lívio o trata como o perpetuador do desejo de seu pai, de guerrear contra as imposições dos tratados romanos. O relato deste juramento, entretanto, é introduzido por "Fama est". Lívio não se responsabiliza assim pelo relato, apresenta como rumor a narrativa de que Aníbal jurara ser eternamente inimigo dos romanos. Sendo verdadeiro ou não o juramento, o ódio implacável aos romanos caracteriza o general do começo ao fim da obra; Aníbal mantem-se fiel a este juramento.

Lívio relata no capítulo terceiro que Aníbal foi aclamado pelo exército como general sucessor de Asdrúbal, o que foi aprovado pelo senado, com uma advertência do chefe do partido opositor. Lívio reporta o discurso em que Anão afirma que o jovem Aníbal deveria ficar em Cartago e aprender a ser submisso às leis e aos magistrados. Através desse discurso Lívio apresenta a tópica, que será outras vezes retomada, de que Aníbal agia por iniciativa própria, muitas vezes contra a decisão do senado cartaginês. E o historiador parece concordar com a opinião da personagem Anão, ao afirmar, que a maioria do Senado venceu a parte melhor, ou seja, a oposição comandada por Anão. Assim Aníbal é retratado como impulsivo e autoritário, como seu pai. Entretanto, Lívio não responsabiliza somente Aníbal pelas causas da segunda guerra púnica (o historiador apresenta como causas fundamentais o ódio e ressentimento de ambos os lados pelo tratado da primeira guerra e a intervenção de Roma no conflito entre Cartago e Sagunto). A versão de que Aníbal agira contra a vontade de sua pátria, seja por cobiça ou por desejo de vingar sua família, não é confirmada pelo historiador. De qualquer maneira, ao longo da narrativa o leitor verá não poucas vezes o Senado enviando reforços e o apoiando, embora no final da guerra isto cesse e Aníbal seja obrigado a regressar à África, ação que o faz também em submissão ao Senado.

\footnotetext{
${ }^{189}$ A tradução é nossa quando não houver indicação da autoria.
} 
Eis o retrato de Aníbal em sua juventude:

Pauci ac ferme optimus quisque Hannoni adsentiebantur; sed, ut plerumque fit, maior pars meliorem vicit. Missus Hannibal in Hispaniam primo statim aduentu omnem exercitum in se conuertit; Hamilcarem iuvenem redditum sibi veteres milites credere; eundem vigorem in voltu vimque in oculis, habitum oris lineamentaque intueri. Dein brevi effecit ut pater in se minimum momentum ad favorem conciliandum esset; nunquam ingenium idem ad res diversissimas, parendum atque imparandum, habilius fuit. Itaque haud facile discerneres utrum imperatori an exercitui carior esset; neque Hasdrubal alium quemquam praeficere malle, ubi quid fortiter ac strenue agendum esset, neque milites alio duce plus confidere aut audere. Plurimum audaciae ad pericula capessenda, plurimum consilii inter ipsa pericula erat; nullo labore aut corpus fatigari aut animus vinci poterat; caloris ac frigoris patientia par; cibi potionisque desiderio naturali non voluptate modus finitus; vigiliarum somnique nec die nec nocte discriminata tempora; id quod gerendis rebus superesset quieti datum; ea neque molli strato neque silentio accersita; multi saepe militari sagulo opertum humi iacentem inter custodias stationesque militum conspexerunt. Vestitus nihil inter aequales excellens; arma atque equi conspiciebantur. Equitum peditumque idem longe primus erat; princeps in proelium ibat, ultimus conserto proelio excedebat. Has tantas viri virtutes ingentia vitia aequabant, inhumana crudelitas, perfidia plus quam Punica, nihil veri nihil sancti, nullus deum metus nullum ius iurandum nulla religio. Cum hac indole virtutum atque vitiorum triennio sub Hasdrubale imperatore meruit nulla re quae agenda videndaque magno futuro duci esset praetermissa.(Liv. 21.4).

Poucos, mas os mais importantes, concordavam com Anão. Entretanto, como se dá na maioria das vezes, a maior parte vence a melhor. Aníbal, enviado à Espanha, logo que chegou converteu a si o exercito. Os soldados veteranos criam que o jovem Amílcar lhes havia sido devolvido. Observavam o mesmo vigor na expressão e força nos olhos, mesma disposição do semblante e mesmos traços. Aníbal, em seguida, para conciliar favores, logo fez com que o pai fosse nele apenas uma pequena recordação. Nunca um mesmo engenho foi tão hábil para as atitudes mais contrárias: o obedecer e o mandar. E assim dificilmente discernirias se havia sido mais caro ao comandante ou ao exército; nem Asdrúbal preferia encarregar outro alguém quando algo devia ser feito com força e diligência, e nem os soldados confiavam mais em outro general, nem obedeciam mais a outro. Possuía o máximo de audácia para afrontar os perigos, o máximo de prudência nestas situações. Seu corpo não podia ser fatigado nem seu fôlego vencido por esforço algum; a mesma resistência ao calor e ao frio. A quantidade de comida e bebida era limitada pela necessidade natural e não pela vontade; seus momentos de vigílias e de sono não eram regidos nem pelo dia nem pela noite. O tempo que restava das atividades realizadas era dado ao repouso, que não era buscado em leito macio ou no silêncio. Muitos frequentemente observaram-no deitado no chão, coberto pelo sago militar, entre os guardas e os postos dos soldados. Suas vestes eram em nada distintas da dos cavaleiros, mas as armas e cavalos eram notáveis. Era de longe o primeiro dos cavaleiros e igualmente dos soldados infantes. Ia à batalha em primeiro, e por último retirava-se da peleja travada. A tamanhas virtudes guerreiras vícios enormes igualavam-se: crueldade desumana, perfídia maior que a púnica, nada de verdadeiro, nada de consagrado, nenhum temor aos deuses, nenhum juramento, nenhuma religiosidade. Com essa natureza de virtudes e vícios militou durante três anos sob o comando de Asdrúbal, sem negligenciar nada que devesse ser feito e visto por um futuro grande general. 
O retrato de Aníbal é feito pela voz e autoridade do historiador, e sintetiza de certa maneira o retrato que é construído ao longo de toda a obra: um caráter ambíguo, de grandes virtudes e grandes vícios.

Primeiramente, Aníbal é comparado ao pai, o que provavelmente não era considerado uma virtude pelos romanos. Aqui, segue-se a preceptiva dos manuais de retórica com relação à ordem, inventio, para o retrato epidítico, pois se fala da ascendência, e de como Aníbal soube tirar proveito desta situação, uma vez que logo o superou ("logo fez com que o pai fosse nele apenas uma pequena recordação").

A única descrição do físico de Aníbal se dá por semelhança ao pai; os dois possuíam os mesmos traços, o que poderia indicar que possuíam também o mesmo caráter, pensando em uma possível tradição de associação entre aparência física e qualidades do caráter, indicada por alguns tratados de fisiognomonia na Antiguidade. A descrição física é entretanto pouco frequente em Lívio com o propósito de caracterização ${ }^{190}$. A comparação com o pai talvez fizesse lembrar vícios. Lívio, pouco antes, sugerira que Amílcar relacionava-se sexualmente com Asdrúbal (21.2.3), e Anão em seguida o vitupera em seu discurso aludindo a essa suspeita. Anão, inclusive, questiona se Aníbal não teria feito o mesmo com Asdrúbal, seguindo os mesmos vícios (21.2.5). Lembramos, entretanto, que tal opinião está relativizada, pois se trata da fala de uma personagem do partido inimigo da família de Aníbal. Esta estratégia será utilizada pelo historiador muitas vezes, como veremos. Embora não nos tenha restado a narrativa de Tito Lívio sobre a primeira guerra púnica, em alguns trechos da terceira década Amílcar é lembrado, e na maioria das vezes vituperado, principalmente nas palavras de inimigos.

Entretanto, o retrato mesmo se encarrega de relativizar a equivalência de Aníbal com o pai, quando Lívio diz que Amílcar logo se tornou apenas uma pequena recordação em Aníbal. O filho supera logo a sua herança, deixando claro que seu caráter será construído por si só. Temos aqui uma tópica da ascendência incrementada, pois ela é mencionada, mas depois superada e se torna pouco importante.

Mas uma parte maior do retrato é dedicada às virtudes guerreiras do Aníbal jovem, ainda sob o mando de Asdrúbal; a caracterização é feita através da descrição da sua relação com os outros soldados e da admiração que esses e o comandante tinham por ele. Lívio afirma que era o general no qual os soldados mais confiavam e obedeciam; e exalta sua discrição em meio aos soldados: 'Muitos frequentemente observaram-no deitado no chão, coberto pelo sago militar, entre os guardas e os postos dos soldados. Suas vestes eram em nada distintas da

\footnotetext{
${ }^{190}$ Evans $(1935,52)$.
} 
dos cavaleiros, mas as armas e cavalos eram notáveis". Tais ações seriam próprias do estereótipo do guerreiro íntegro, que não se vale da influência para conseguir vantagens. E exalta sua prudência e coragem na batalha através de seus hábitos: "Era de longe o primeiro dos cavaleiros e igualmente dos soldados infantes. Ia à batalha em primeiro, e por último retirava-se da peleja travada".

Lívio vale-se da descrição de ações convencionais naquela sociedade para qualificá-lo da maneira que deseja; de hábitos que eram associados a determinado tipo de comportamento, e, assim, imita mais modelos da tradição do que a realidade. Levene identifica semelhanças entre o retrato de Aníbal e os de Catilina e Jugurta de Salústio ${ }^{191}$. O estudioso considera o retrato de Aníbal, tematicamente, uma mistura dos dois, e confirma o intertexto afirmando que no trecho do retrato Lívio escreve ao estilo de Salústio mais do que usualmente o faz.

Catilina, nobili genere natus, fuit magna vi et animi et corporis, sed ingenio malo pravoque. Huic ab adulescentia bella intestina, caedes, rapinae, discordia civilis grata fuere, ibique iuventutem suam exercuit. Corpus patiens inediae, algoris, vigiliae supra quam cuiquam credibile est. Animus audax, subdolus, varius, cuius rei lubet simulator ac dissimulator, alieni adpetens, sui profusus, ardens in cupiditatibus; satis eloquentiae, sapientiae parum. Vastus animus inmoderata, incredibilia, nimis alta semper cupiebat.

Lucio Catilina, oriundo de família nobre, era de grande vigor físico e intelectual, mas de índole má e depravada. Desde a adolescência foram do seu agrado as guerras internas, os assassínios, os roubos, as discórdias entre cidadãos e neles exercitou sua juventude. Seu corpo suportava a fome, o frio, as vigílias bem além do que qualquer pessoa possa acreditar. Espírito atirado, astuto, versátil, capaz de todo fingir e dissimular, ávido dos bens alheios, pródigo dos seus, fogoso nas paixões; de muita eloquência, de pouca sabedoria. Espírito desmesurado, estava sempre a ambicionar coisas sem limites, as fantásticas, as altas demais. ${ }^{192}$

Ambos os retratos, o de Lívio e os de Salústio, ocupam a mesma posição na narrativa: após a introdução e antes da narrativa das primeiras ações da guerra. James Clauss, referindose ao procedimento de Lívio como arte alusiva, observa as seguintes semelhanças entre o retrato de Aníbal e o de Catilina: ecos de semelhanças vocabulares, ambos os generais possuem poderes físicos e intelectuais, ambos tem corpos resistentes à situações como o frio (patientia aparece nos dois retratos), ambos combinam paradoxalmente traços positivos e negativos; Lívio utiliza, incomumente, o estilo breve e paratático de Salústio no retrato ${ }^{193}$. O autor também relaciona a suspeita da corrupção sexual de Aníbal, antes mencionada por Anão, à corrupção de jovens por Catilina (Sal. Cat. 14,7). Clauss demonstra que Aníbal é

\footnotetext{
${ }^{191}$ Cf. Levene $(2010,101)$.

${ }^{192}$ Sal. Cat. 5.1-5. Tradução de Antonio da Silveira Mendonça.

${ }^{193}$ Clauss $(1997,171-3)$.
} 
caracterizado, assim como Salústio, como uma figura trágica movida por ambição de poder e ódio pelos seus inimigos, e isso terá um fim desastroso.

Segundo Andreola Rossi, o subtexto salustiano convida o leitor a ver Aníbal, levado pela cupido imperi (já mencionada no discurso de Anão), como alguém que também subverte as normas da complexa relação entre público e privado ${ }^{194}$. Cícero, nas Catilinárias, já havia comparado Catilina a Aníbal, pois o conjurador torna-se inimigo e ameaça para Roma, e Aníbal era o principal modelo de inimigo romano $(4,21 ; 7,2,6-7)$. Segundo o estudioso, a associação com Catilina, ícone da degeneração moral, traz uma lembrança mais recente para a audiência de Lívio de como o ódio e o desejo de poder são exemplos ruins. Para Clauss, Aníbal do retrato é o outro, menos virtuoso que os romanos, que o derrotarão ${ }^{195}$. Parece-nos, assim, que, seguindo tais ideias, Lívio com isso também convida o leitor a ver Catilina, romano, como estrangeiro, o que corrobora para a ideia de decadência do presente advinda de uma corrupção externa. Na composição de Aníbal como Catilina Lívio pode estar também alertando para a ameaça que Aníbal representava não só para Roma, mas também para seu próprio país.

Entretanto, é preciso considerar o retrato de Aníbal em sua totalidade, e também sua associação com o retrato que Salústio faz de Jugurta. Aníbal é fisicamente resistente como Catilina, mas a descrição de seu comportamento ecoa mais o retrato de Jugurta:

Qui ubi primum adolevit, pollens viribus, decora facie, sed multo maxime ingenio validus, non se luxu neque inertiae corrumpendum dedit, sed, uti mos gentis illius est, equitare, iaculari; cursu cum aequalibus certare et, cum omnis gloria anteiret, omnibus tamen carus esse; ad hoc pleraque tempora in venando agere, leonem atque alias feras primus aut in primis ferire, plurimum facere, et minimum ipse de se loqui. [...]Nam Iugurtha, ut erat impigro atque acri ingenio, ubi naturam P. Scipionis, qui tum Romanis imperator erat, et morem hostium cognovit, multo labore multaque cura, praeterea modestissime parendo et saepe obviam eundo periculis in tantam claritudinem brevi pervenerat, ut nostris vehementer carus, Numantinis maximo terrori esset. Ac sane, quod difficillimum in primis est, et proelio strenuos erat et bonus consilio, quorum alterum ex providentia timorem, alterum ex audacia temeritatem afferre plerumque solet. Igitur imperator omnis fere res asperas per Iugurtham agere, in amicis habere, magis magisque eum in dies amplecti, quippe cuius neque consilium neque inceptum ullum frustra erat. Hoc accedebat munificentia animi atque ingeni sollertia, quibus rebus sibi multos ex Romanis familiari amicitia coniunxerat.

Assim que Jugurta chega à juventude, cheio de forças, de belo semblante, acima de tudo de uma inteligência vigorosa, não se deixou corromper pelo luxo nem pela ociosidade, mas, como é costume nesse povo, praticava a equitação, lançava o dardo, competia em corrida com os de sua idade; mais, passava a maior parte do tempo na caça, era o primeiro ou estava entre os primeiros a atacar o leão e os outros animais; realizava o máximo e falava o mínimo de si. [...] Com efeito, Jugurta, de espírito ágil e fino, ao tomar conhecimento do caráter de Cipião e dos hábito dos inimigos, à custa de muito trabalho e

\footnotetext{
${ }^{194}$ Rossi (2004, 376-7).

${ }^{195}$ Clauss (1997, 180).
} 
muita dedicação, e mais, obedecendo com grande equilíbrio e arrostando os perigos, chegou a um tal grau e prestígio que despertou nos nossos grande afeição e nos numantinos, o maior terror. Realmente, reunia em si duas qualidades particularmente muito difíceis, era arrojado no combate e nas decisões ponderado; uma, na maioria das vezes, transforma prudência em medo, a outra a bravura em temeridade. Em vista disso, o comandante confiava a Jugurta quase todas as missões difíceis, contava-o entre os seus amigos, cercava-o a cada dia e maiores atenções, uma vez que todo plano ou iniciativa sua nunca deixavam a desejar. A isso se acrescentava a generosidade e a argúcia do seu espírito que lhe granjearam estreita amizade com muito romanos ${ }^{196}$.

Algumas descrições são bastante semelhantes, com vocábulos próximos. Lívio ressalta as qualidades da audácia e astúcia respectivamente (Plurimum audaciae ad pericula capessenda, plurimum consilii inter ipsa pericula erat), assim como Salústio afirma que Jugurta era corajoso em batalha e de boa astúcia (proelio strenuos erat et bonus consilio). Por meio da descrição do comportamento com os outros soldados, ambos são qualificados com a modéstia e obediência (parendum(o) aparece em ambos). Aníbal era o primeiro a ir à batalha e Jugurta o primeiro a atacar o leão, ambos tinham a confiança do líder para realizar missões difíceis ("ubi quid fortiter ac strenue agendum esset" / "res asperas per Iugurtham agere”).

Que sentidos, entretanto, a figura de Jugurta poderia acrescentar ao êthos de Aníbal? Jugurta, segundo o retrato de Salústio, era na juventude um estrangeiro virtuoso, e é posteriormente corrompido em meio aos romanos, e seus futuros subornos tornar-se-ão um problema na guerra contra Roma. A lembrança de Jugurta funcionaria, assim, como um alerta de que a virtuosidade do jovem Aníbal pode ser corrompida, e também como um reforço da ameaça, militar e moral, que Aníbal representa para Roma. Justapondo, assim, Catilina, um romano vicioso, e Jugurta, um estrangeiro virtuoso, Lívio parece relativizar e problematizar a oposição simplista de considerar sempre o estrangeiro vicioso e o romano virtuoso. Levene aponta que a concepção de Tito Lívio sobre esta partição não é tão simples, sendo que muitos romanos agem viciosamente também no passado e alguns estrangeiros são caracterizados com qualidades romanas ${ }^{197}$. Aníbal é um pouco romano e um pouco estrangeiro, é um estrangeiro virtuoso, mas não seria mais que um romano virtuoso, já que Catilina era um romano vicioso. E no fim a virtuosidade romana o vencerá, mas é necessário que ele seja um inimigo virtuoso para que a glória do vencedor seja maior. Aníbal é ambíguo como Catilina, e ambiguamente Catilina e Jugurta.

Como já dissemos, através de alguma ações descritas do general, suas virtudes guerreiras como humildade, força, prudência e coragem são acrescidas a seu caráter. Além da exaltação de virtudes guerreiras, que serão ao longo na narrativa confirmadas pelo agir de

\footnotetext{
${ }^{196}$ Sal. Jug. 6-7. Tradução de Antonio da Silveira Mendonça.

${ }^{197}$ Cf. Levene (2010, 103).
} 
Aníbal, louva-se também a qualidade moral da disciplina e moderação, ao dizer que "A quantidade de comida e bebida era limitada pela necessidade natural e não pela vontade; seus momentos de vigílias e de sono não eram regidos nem pelo dia nem pela noite". Alguns estudiosos discutem a relação entre o trecho e as doutrinas estoicas e epicuristas. Entretanto, não é possível precisar se Lívio alude ou segue alguma doutrina, ou se somente está reproduzindo uma ideia do senso comum da época: só podemos afirmar que a desmedida e o exagero eram considerados viciosos. Claramente Lívio vale-se da oposição, lugar-comum, entre dois padrões de comportamento: o caráter disciplinado e o entregue às paixões (luxúria, gula, conforto): "O tempo que restava das atividades realizadas era dado ao repouso, que não era buscado em leito macio ou no silêncio". Aníbal não era dado a nenhum tipo de conforto. Esta condição contrastará com o episódio da estadia em Cápua, na qual a disciplina do exército cederá lugar a luxos, que afrouxará a disciplina militar. Mais uma vez fica evidente que Lívio lida com convenções sociais, estereótipos de comportamento de sua sociedade para pintar um determinado retrato.

Mais espaço é destinado às virtudes no retrato. Aproximadamente apenas um quarto da descrição, no final, tematiza seu vícios explicitamente. Entretanto, o historiador afirma que vícios graves contrabalanceiam as virtudes: inhumana crudelitas, perfidia plus quam Punica, nihil veri nihil sancti, nullus deum metus nullum ius iurandum nulla religi. Foulks afirma que tais atributos negativos de Aníbal são magnificações das características gerais tidas como dos cartagineses, e são vícios que contrastam definitivamente com virtudes romanas ${ }^{198}$. De fato, o historiador sintetiza os vícios do general apontando atributos característicos do estereótipo do fenício já existente. Franko ${ }^{199}$ examina as ocorrências de poenus e carthaginiensis na literatura latina inicial e demonstra que o termo poenus é utilizado sempre como um rótulo étnico com conotação negativa, ao passo que cartaginês é um termo mais neutro, utilizado com referencia uma característica civil. Plauto, em Poenuculus (título já pejorativo por causa do diminutivo), lida com o estereótipo do púnico como efeminado, fétido, lascivo e, principalmente, pérfido (Poen. 111-13). Em Casina, Plauto apresenta os Púnicos (assim como os Gregos e os Apulienses) como mentirosos e traiçoeiros (Cas. 75-77).

Segundo Franko, as citações de 'poenus' em Ênio, nos Annales, refletem o estereótipo da crueldade, arrogância e efeminação. No frag. 287, os púnicos são descritos como cruéis por cortarem os tendões dos soldados derrotados. Em Políbio, o termo 'phoinikes' é usado poucas

\footnotetext{
${ }^{198}$ Foulks $(1999,75)$.

${ }^{199}$ Franko (1994).
} 
vezes (comparado com 'karkhedonioi'), e sempre com sentido étnico e pejorativo: nessas passagens os púnicos são depreciados como ardilosos, ambiciosos e físicamente inferiores ${ }^{200}$.

O estereótipo do púnico como pérfido aparece em Tito Lívio não apenas no retrato de Aníbal (perfidia plus quam Punica), mas em muitas outras passagens. Em 22.48.1 e 30.22.6 o historiador refere-se à púnica fraus, em 25.39.1, à punica ars, com o sentido de artimanha, em 42.47.7, à versutia púnica e em 24.62.2, ao ingenium púnico. É notável a oposição na obra entre a bravura romana e as insídias cartaginesas. Em 22.6.12, Aníbal é caracterizado como de nulla fides pelo historiador através do esteriótipo do púnico pérfido. Lívio relata que Maharbal, cartaginês, persegue os fugitivos da batalha e promete que poderiam partir com a roupa do corpo desde que entregassem as armas; Aníbal, entretanto, não cumpre o acordo e faz todos prisioneiros. O historiador então afirma que o acordo foi cumprido com Punica religione, lealdade púnica, ou seja, os soldados foram enganados.

Parece evidente, assim, que ao apresentar os vícios de Aníbal, Lívio está lidando com um estereótipo do púnico como pérfido já existente, e afirma que Aníbal era ainda mais pérfido que a sua etnia. Com exceção da crueldade, que, como vimos, parece que era também considerada uma característica dos fenícios por alguns, os outros vícios mencionados no retrato são desdobramentos dos vícios da perfídia e mendacidade: nada de verdadeiro, de sagrado, de palavra e religião. Tais vícios serão confirmados ou refutados pelas várias vozes da narrativa. A caracterização de Aníbal como cruel envolve muito boatos de ações que Aníbal teria realizado.

A conclusão do retrato reafirma a ambiguidade do caráter de Aníbal, uma natureza de vícios e virtudes, e antecipa que o cartaginês seria um grande general. Embora os vícios apontados pelo historiador sejam graves, é notável o louvor do general com relação às suas virtudes guerreiras, principalmente. Segundo Levene, tal louvor inicial de Aníbal e a sua trajetória ascendente, as vitórias nos primeiros livros da terceira década, funcionam como um questionamento aos romanos de que qualidades de Aníbal lhes estariam faltando ${ }^{201}$. Em alguns momentos, Aníbal será retratado mais como romano do que bárbaro, pois quase levou Roma à derrota.

Ao longo da narrativa, as virtudes guerreiras de Aníbal serão ilustradas pelo seu agir. Embora a perfídia de Aníbal seja um vício, sua capacidade estratégica militar parecerá ser louvada no decorrer da narrativa. De igual maneira, vícios também serão ilustrados, mas veremos que não poucas vezes o historiador parece questionar boatos sobre ações viciosas do

\footnotetext{
${ }^{200}$ Cf. Franko (1994, 157-8).

${ }^{201}$ Levene $(2010,228)$.
} 
general, mantendo-os como boatos. Como veremos, o êthos do general é ambíguo também ao longo da narrativa, pois parece o historiador o constrói de maneira a muitas vezes despistar o leitor, deixar questões em aberto. Veremos quais as possíveis razões de tais ambiguidades na obra.

\subsection{Aníbal em cena e em debate}

O livro 21 trata das origens e primeiros movimentos da Segunda Guerra Púnica. Após a apresentação de Aníbal no retrato, suas primeiras ações descritas são o comando do exército no cerco à cidade de Sagunto, aliada romana, tomada pelos cartagineses sem grandes dificuldades. Segundo o historiador, Aníbal aproveita o momento em que as fortalezas da cidade já estavam enfraquecidas e toma a praça da cidade. A atitude seguinte do general é considerada cruel pelo narrador:

[...] totis viribus adgressus urbem momento cepit, signo dato ut omnes puberes interficerentur. Quod imperium crudele ceterum prope necessarium cognitum ipso eventu est: cui enim parci potuit ex iis qui aut inclusi cum coniugibus ac liberis domos super se ipsos concremaverunt aut armati nullum ante finem pugnae quam morientes fecerunt (Liv. 21.14.3-4)

[...] em instantes [Aníbal] atacou e capturou a cidades com seus soldados: deu o sinal para que matassem todos os homens. Foi uma ordem cruel, contudo, diante do ocorrido, julgou quase inevitável: pois quem pôde ser poupado daqueles que trancados com suas esposas e filhos incendiaram as casas sobre si, ou, armados, nada fizeram antes do fim da batalha senão morrer?

O historiador parece considerar a ordem cruel, mas não concorda nem discorda da opinião de Aníbal, de que era necessária em vista da covardia dos saguntinos.

Após Sagunto, Lívio descreve, no par. 21, Aníbal discursando aos seus homens, animando-os para a guerra contra Roma, em busca de glória e despojos imensos, e relata o momento em que Aníbal cumpre votos a Hércules. Tal ação contraria claramente a afirmação do retrato (21.4) de que ele possuía o vício de nulla relligio. Em muitos outros momentos, Aníbal será descrito realizando votos, funerais, e outras ações piedosas (21.45.8). Ele é descrito algumas vezes realizando funerais dos cônsules e romanos mortos nas batalhas (27.28.1). Em outros momentos, entretanto, Aníbal é descrito pilhando templos, embora isto seja mais criticado por causa de cobiça, ou justificado por necessidade, do que por causa de profanação (26.11.9). O próprio juramento realizado aos noves anos constituía um ato religioso. E mais, o fato de Aníbal ter seguido o seu juramento, embora seja este um juramento hostil a Roma, demonstra virtude, uma vez que revela a fides do general para com seu voto, pai e pátria. É verdade, entretanto, que na maioria das vezes em que ele age com fidelidade, está em jogo também algum interesse pessoal. A fides, entretanto, é uma das 
virtudes a que Lívio dá maior importância. Segundo Moore, nenhuma virtude além da fides desempenha um papel tão importante no texto de Lívio; o foco é primeiramente a fides publica (como discussões sobre alianças e quebra de acordos), mas ela é também é apresentada como uma importante qualidade pessoal, e Aníbal é sim, muitas vezes descrito como digno de ser confiado, sendo uma figura mais complexa do que um homem de perfídia mais que púnica ${ }^{202}$.

Lívio descreve a preparação do exército por Aníbal, sua passagem pelo Ebro e Pirineus, sua diplomacia para com os povos locais (21.26), a dificuldade da travessia dos elefantes pelo rio Ródano (21.28), e a decisão de seguir para a Itália pelos Alpes. O relato da travessia pelos Alpes (21.30-38) enfatiza e detalha as inúmeras dificuldades. Primeiro, os ataques dos povos alpinos em um terreno desfavorável, o frio e fome, a descida íngreme na qual escorregavam soldados e animais de carga, e um bloqueio rochoso no meio da rota. $\mathrm{O}$ historiador descreve como os homens, com muito trabalho (4 dias), destruíram o obstáculo. Lívio não conclui se as perdas sofridas pela travessia dos Alpes foi muito significativa, pois apresenta versões variadas sobre o número inicial de soldados e baixas. No capítulo 39, entretanto, Lívio afirma que os soldados após a descida estavam fatigados, e quase tornados ao estado selvagem. Lívio não parece apontar a passagem nem como um erro de estratégia, que levou a inúmeras baixas, e também não tece elogios claros à façanha. A resposta para se Aníbal acertou ou não parece vir dos fatos seguintes: o general vencerá sucessivamente.

Aníbal, demonstrando uma capacidade de liderança incrível, é descrito por Lívio encorajando os soldados através de um exemplum. Lívio relata, em 51.42-44, que Aníbal considerou necessário exortá-los mais com uma ação do que com palavras (rebus prius quam verbis), e então organiza uma luta entre prisioneiros até a morte, prometendo armas e um cavalo ao vencedor. Após o espetáculo proporcionado aos seus homens, Aníbal discursa fazendo com que se comparem aos prisioneiros: se forem derrotados, serão prisioneiros, pois não haverá como fugir da Itália, então as únicas opções são a morte, uma vez que é melhor morrer do que submeter-se $\mathrm{e}^{203}$, ou a vitória, que os levaria a grandes despojos. Os soldados inflamam-se com o discurso do cartaginês, apoiado por um espetáculo. Evidencia-se assim nesta anedota a importância da visão no despertar da paixão, e consequentemente da persuasão.

Por muitos de seus próprios discursos, muitos diante das batalhas, o êthos de Aníbal é construído como o de um grande líder, que brilhantemente controlava e exortava seus

\footnotetext{
202 Moore (1989, 133).

${ }^{203} \mathrm{O}$ discurso de Aníbal apresenta certa semelhança com o discurso de Catilina criado por Salústio, o qual argumenta que é melhor a morte corajosa do que viver miseravelmente em mãos alheias (Sal. Cat. 20).
} 
homens. Em 25.11.17-18, Lívio descreve que os cidadãos de Tarento ficaram admirados com o discurso de Aníbal, que demonstrara grande inteligência. O caráter de Aníbal como grande general em liderança é louvado pelo historiador no livro 28, que narra um momento em que Aníbal sofria já muitas adversidades:

Cum Hannibale nihil eo anno rei gestum est. Nam neque ipse se obtulit in tam recenti volnere publico priuatoque neque lacessierunt quietum Romani: tantam inesse vim, etsi omnia alia circa eum ruerent, in uno illo duce censebant. Ac nescio an mirabilior adversis quam secundis rebus fuerit, quippe qui, cum in hostium terra per annos tredecim, tam procul ab domo, varia fortuna bellum gereret, exercitu non suo civili sed mixto ex conluvione omnium gentium, quibus non lex, non mos, non lingua communis, alius habitus, alia vestis, alia arma, alii ritus, alia sacra, alii prope dei essent, ita quodam uno vinculo copulauerit eos ut nulla nec inter ipsos nec adversus ducem seditio exstiterit, cum et pecunia saepe in stipendium et commeatus in hostium agro deessent, quorum inopia priore Punico bello multa infanda inter duces militesque commissa fuerant. [...] $\mathrm{Nec}$ ab domo quicquam mittebatur de Hispania retinenda sollicitis, tamquam omnia prospera in Italia essent (Liv. 28.12.1-9).

Naquele ano nada foi feito contra Aníbal. Pois nem ele se expôs, devido às recentes feridas tanto de seu país quanto de sua família, nem os romanos importunaram seu repouso: tão grande era a força arrogada àquele general único, ainda que as coisas em torno dele estivessem ruindo. E não sei se ele foi mais admirável nas adversidades ou nas situações favoráveis; pois, durante treze anos em território inimigo, tão longe de sua pátria, geria uma guerra de fortuna diversa, com um exército composto não por concidadãos, mas por uma mixórdia de toda sorte de povos, que não tinham leis, nem maneiras, nem língua comuns, hábitos diferentes, roupas, armas variadas, ritos e sacrifícios distintos, e praticamente outros deuses. Assim uniu-os por um único vínculo de maneira que nunca existiu entre eles contenda e sedição alguma contra o comandante, embora sempre faltasse dinheiro para o pagamento e manutenção no campo inimigo, privação que na primeira guerra púnica fora motivo de muitas atrocidades e delitos entre os comandantes e soldados. [...] E nada era enviado de Cartago, que se dedicava aos movimentos na Hispânia, como se tudo estivesse prosperando na Itália.

Lívio admira a capacidade de Aníbal liderar por treze anos um exército composto de homens de várias etnias, que não tinham em comum nem leis, nem língua e tampouco hábitos, de maneira que nunca houve entre eles contenda alguma. A visão favorável de Lívio sobre o comando de Aníbal fica aqui evidente por tais elogios, tecidos diretamente pela voz do historiador. Esta qualidade é o que define um bom general na visão de Políbio (19.3-5): para o historiador grego, era responsabilidade do general impedir o descontrole dos soldados, quer seja o comodismo e relaxamento, a cobiça, ou o medo antes das batalhas. Em fragmento do livro 23.13, Políbio vê a capacidade de controle como uma prova de que Aníbal fora a um general superior a todos em comando. Lívio afirma também, no trecho acima, que Aníbal foi melhor general na adversidade, colaborando para a ideia, que nos parece corrente no livro, como veremos, de que nos tempos de bonança a disciplina e valor são afrouxados. 
Mas passemos às écfrases das batalhas vencidas por Aníbal, que, sobretudo, evidenciarão sua capacidade estratégica. A descrição da batalha às margens do Ticino (21.4546), lutada contra Cipião, pai do Cipião Africano, evidencia a inteligencia militar do cartaginês, que posicionou bem sua cavalaria, e animou seus homens. Segundo o historiador, após um longo combate de cavalarias, que se tornou em seguida um combate de infantaria, os númidas atacam os romanos por trás, conforme a ordem de Aníbal. Lívio justifica a derrota romana pelo fato da cavalaria de Aníbal ser mais forte (21.47.1), e o terreno plano não convir então para os romanos. Mas parece que a exortação de Aníbal teve também seu peso, e em contrapartida, os romanos haviam sido assustados por maus presságios (21.46.1-3).

A batalha que acontece em Trébia é descrita por Lívio como iniciada devido à estratégia de Aníbal. O historiador relata que Aníbal conhecia o caráter do cônsul Semprônio, que estava ansioso por combater (21.53.7-8), e prepara então uma emboscada. Lívio relata que o cartaginês procurou um local para emboscada (insidiis, 21.53.11), e lá posiciona Magão e mil homens valorosos; em seguida reporta a fala de Aníbal: "Magão vos mostrará o lugar no qual se dará a emboscada; tereis um inimigo cego nestas artimanhas de guerra". O historiador narra que Aníbal envia a cavalaria númida além do rio Trébia a fim de, com dardos, provocar o início da batalha em momento que os romanos não tinham ainda se alimentado nem estavam devidamente preparados para a batalha (54.6-9), e os atraísse para o outro lado do rio. Este fator foi decisivo para a vitória cartaginesa segundo Lívio, pois desequilibrou, juntamente com o bom posicionamento dos homens de Aníbal, a igualdade da força dos dois exércitos (21.55.8). Através da descrição da batalha, o leitor pode ver como se deu a movimentação de cada parte do exército, de ambos os lados, e observa como o posicionamento estratégico planejado por Aníbal foi decisivo para o rumo do combate. A imagem que se tem dos romanos é de desordem na luta, pegos de surpresa pelas artimanhas cartaginesas, e a descrição é clara de como muitos foram apanhados até mesmo na fuga. A descrição do local contribui para a imagem da cena de batalha como difícil para os romanos, uma vez que o historiador descreve que os romanos molharam-se no rio e na neve, e ainda a chuva contribui para o atmosfera da tragédia romana. No relato da batalha de Trébia, fica evidente o contraste entre a precipitação do cônsul Semprônio, com a prudência e estratégia do cartaginês.

Após o relato de uma dificuldade do exército cartaginês em atravessar um longo pântano (episódio em que Aníbal perde um olho devido a uma infecção, 22.2), Lívio narra os acontecimentos da batalha próxima ao lago Trasimeno. Mais uma vez, a inteligência de Aníbal vencerá diante da ansiedade romana. Lívio descreve o cônsul Flamínio enfurecido, 
ardente por guerra (22.3), embora em 22.5.1 o cônsul seja descrito como o único calmo em meio ao ataque inesperado. A estratégia de Aníbal é descrita em detalhes em 22.4: Aníbal aproveita o local entre o lago e uma cadeia de montanhas para cercar o exército romano de um lado com seu acampamento, e de outro com sua cavalaria. A descrição dos movimentos do ataque e da fuga romana é cinematográfica:

Romanus clamore prius undique orto quam satis cerneret se circumuentum esse sensit, et ante in frontem lateraque pugnari coeptum est quam satis instrueretur acies aut expediri arma stringique gladii possent. Consul perculsis omnibus ipse satis ut in re trepida impauidus, turbatos ordines, uertente se quoque ad dissonos clamores, instruit ut tempus locusque patitur, et quacumque adire audirique potest, adhortatur ac stare ac pugnare iubet: nec enim inde uotis aut imploratione deum sed ui ac uirtute euadendum esse; per medias acies ferro uiam fieri et quo timoris minus sit, eo minus ferme periculi esse. Ceterum prae strepitu ac tumultu nec consilium nec imperium accipi poterat, tantumque aberat ut sua signa atque ordines et locum noscerent, ut uix ad arma capienda aptandaque pugnae competeret animus, opprimerenturque quidam onerati magis iis quam tecti. Et erat in tanta caligine maior usus aurium quam oculorum. Ad gemitus uolnerum ictusque corporum aut armorum et mixtos strepentium pauentiumque clamores circumferebant ora oculosque. Alii fugientes pugnantium globo inlati haerebant; alios redeuntes in pugnam auertebat fugientium agmen. Deinde, ubi in omnes partes nequiquam impetus capti et ab lateribus montes ac lacus, a fronte et ab tergo hostium acies claudebat apparuitque nullam nisi in dextera ferroque salutis spem esse, tum sibi quisque dux adhortatorque factus ad rem gerendam, et noua de integro exorta pugna est, non illa ordinata per principes hastatosque ac triarios nec ut pro signis antesignani, post signa alia pugnaret acies nec ut in sua legione miles aut cohorte aut manipulo esset; fors conglobat et animus suus cuique ante aut post pugnandi ordinem dabat tantusque fuit ardor animorum, adeo intentus pugnae animus, ut eum motum terrae qui multarum urbium Italiae magnas partes prostrauit auertitque cursu rapidos amnes, mare fluminibus inuexit, montes lapsu ingenti proruit, nemo pugnantium senserit. Tres ferme horas pugnatum est et ubique atrociter; circa consulem tamen acrior infestiorque pugna est. Eum et robora uirorum sequebantur et ipse, quacumque in parte premi ac laborare senserat suos, impigre ferebat opem, insignemque armis et hostes summa ui petebant et tuebantur ciues, donec Insuber eques —Ducario nomen erat_facie quoque noscitans consulem, "[En]" inquit "hic est" popularibus suis, "qui legiones nostras cecidit agrosque et urbem est depopulatus; iam ego hanc uictimam manibus peremptorum foede ciuium dabo". Subditisque calcaribus equo per confertissimam hostium turbam impetum facit obtruncatoque prius armigero, qui se infesto uenienti obuiam obiecerat, consulem lancea transfixit; spoliare cupientem triarii obiectis scutis arcuere. Magnae partis fuga inde primum coepit; et iam nec lacus nec montes pauori obstabant; per omnia arta praeruptaque uelut caeci euadunt, armaque et uiri super alium alii praecipitantur. Pars magna, ubi locus fugae deest, per prima uada paludis in aquam progressi, quoad capitibus [umeris] exstare possunt, sese immergunt; fuere quos inconsultus pauor nando etiam capessere fugam impulerit; quae ubi immensa ac sine spe erat, aut deficientibus animis hauriebantur gurgitibus aut nequiquam fessi uada retro aegerrime repetebant atque ibi ab ingressis aquam hostium equitibus passim trucidabantur. Sex milia ferme primi agminis per aduersos hostes eruptione impigre facta, ignari omnium quae post se agerentur, ex saltu euasere et, cum in tumulo quodam constitissent, clamorem modo ac sonum armorum audientes, quae fortuna pugnae esset neque scire nec perspicere prae caligine poterant. Inclinata denique re, cum incalescente sole dispulsa nebula aperuisset diem, tum liquida iam luce montes campique perditas res stratamque ostendere foede Romanam aciem. Itaque ne in conspectos procul immitteretur eques, sublatis raptim signis quam citatissimo poterant agmine sese abripuerunt. (Liv.22.4.7- 22.6.10). 
Pelo grito que surgia de todos os lados, os romanos perceberam que estavam cercados, antes mesmo de conseguirem enxergar, e iniciou-se o ataque na frente e nas laterais antes que pudessem dispor as linhas, armar-se e desembainhar as espadas. [5] Mesmo em meio a todas estas dificuldades, uma situação assustadora, o cônsul estava tranquilo. Ele reordena as linhas desfeitas na movimentação dos que se voltavam diante dos gritos dissonantes, na medida em que o lugar e o tempo permitiram, e onde podia ir e ser ouvido, exorta e ordena que fiquem e lutem: salvar-se-iam não por meio de votos e clamor ao deuses, mas pela força e coragem; é a espada que abre caminho por meio das fileiras e, quanto menor o medo, menor o perigo. Mas por causa do barulho e do tumulto tal plano e ordens não podiam ser ouvidas, e os soldados estavam tão distantes que não reconheciam as insígnias, filas e posições, e tiveram dificuldades para apanhar as armas e preparar-se para luta, e alguns, para os quais as armas eram mais um peso do que proteção, foram mortos. E em meio à tamanha névoa eram os ouvidos mais úteis que os olhos. As faces e olhares voltavam-se nas várias direções dos gemidos dos feridos, do som dos choques dos corpos e armas, e dos gritos dos que atacavam e dos apavorados. Alguns, fugindo, davam com um grupo de combatentes e lá ficavam; outros, quando voltavam para a luta, eram desviados por uma corrente de fugitivos. Enfim, quando o ataque era vão em todas as partes, cercados pelos montes e pelo lago nas laterais e pelo exército inimigo na frente e atrás, e percebeu-se que não havia outra esperança de salvação senão as armas e suas próprias mãos, então cada um torna-se seu próprio general e exortador para realizar suas ações, e uma nova luta originou-se da virtude, sem que houvesse uma formação de filas de príncipes e hastados ou triários, e em que os porta-bandeiras lutam antes das insígnias e o exército depois, e nem como quando cada soldado permanece em sua legião, coorte ou pelotão: a sorte os reunia e o ânimo de cada um posicionava-os antes ou depois da linha de luta. E tamanho foi o ímpeto dos espíritos e a tal ponto o ânimo da luta esforçado que ninguém entre os que lutavam percebeu a ocorrência de um terremoto que destruiu grandes extensões de cidades italianas, desviou correntes dos rios de seu curso, levou o mar para dentro dos rios e provocou a queda de montanhas com uma enorme avalanche. [6] O combate prolongou-se por quase três horas e de maneira violenta em todas as partes; entretanto, próximo ao cônsul era mais feroz e hostil. A elite dos soldados o seguia e ele mesmo prontamente levava socorro a qualquer lugar em que percebesse que os seus estavam sobrecarregados. Percebidas suas armas e seu distintivo, os soldados inimigos e os romanos dirigiam-se a ele com grande violência, até que um cavaleiro da Insubria, cujo nome era Ducário, também reconhecendo a presença do cônsul, diz aos seus compatriotas: "Ali está! Aquele que destruiu as nossas legiões e devastou nossos campos e cidade! Eu agora o oferecerei como sacrifício aos manes de nossos conterrâneos assassinados indignamente! E acicatando o cavalo, atira-se pela multidão mais cerrada de inimigos, e após matar o escudeiro que se interpôs em seu caminho, transpassou o cônsul com a lança. Desejando espoliá-lo, os triários interpuseram seus escudos e o afastaram. Grande parte dos romanos então começa a fugir, e nem o lago nem os montes eram mais obstáculos para os apavorados; por todas as frestas e precipícios, como se cegos, escapam, e homens e armas caem sobre uns e outros. Muitos, não tendo por onde fugir, adentram nas águas da margem do lago, até onde conseguem permanecer com apenas as cabeças acima da água; houve alguns que o pânico irrefletido impulsionou a tentar a fuga nadando; e sendo a fuga impossível e sem esperança, alguns tiveram suas forças esgotados na correnteza, ou, fatigados, retornavam em vão com sofrimento para o lutar anterior, e ali eram por toda parte massacrados pelos cavaleiros inimigos que haviam ingressado na água. Cerca de seis mil homens, a vanguarda do exército, fizeram um assalto violento pela barreira de inimigos, ignorando o que acontecia com aqueles que estavam atrás, e saíram do desfiladeiro e, quando se detiveram em uma colina, ouviam gritos e o som das armas, mas não podiam nem saber nem distinguir qual tinha sido a fortuna da batalha por causa da névoa. Acabada por fim a batalha, nasceu o dia, dispersando a névoa com o sol incandescente, e a luz clara nos montes e campos revelou a derrota e o exército romano terrivelmente arruinado. 
A cena descreve inicialmente reação do exército romano ao ser cercado inesperadamente e a reação do cônsul. Em 22.5.1 o historiador narra o esforço do comandante romano para reorganizar a formação do exército. Tais ações são descritas com verbos no presente do indicativo (instruit, adhortatur, iubet), o que coopera para trazer o evento descrito para diante dos olhos do leitor. Na descrição do combate em seguida, os verbos estão no pretérito imperfeito do indicativo, o que também coopera para criar uma cena ecfrástica, uma vez que o tempo verbal, de aspecto infectum, transforma a cena mais estática, de maneira que o leitor é levado até ela e pode contemplar os detalhes descritos. Para narrar o ataque de Ducário ao cônsul, o historiador utiliza também verbos no tempo presente. O foco da narrativa, cinematograficamente, centra-se no soldado, presentificado não só pelo tempo verbal de sua ação, mas também pela introdução do discurso direto. A fala reproduzida diretamente torna a cena dramática, e o dêitico utilizado para referir-se ao cônsul também remete também a ação de olhar. Como vemos, vários elementos contribuem para a enárgeia na descrição: o detalhamento das ações, o emprego do presente e do pretérito imperfeito, o estilo direto da personagem que intervém no relato e o uso de dêiticos.

A fuga desesperada e caótica dos romanos é também posta diante dos olhos, também através de uma descrição detalhada, pormenorizada, e com verbos na maioria também no tempo presente ("Magnae partis fuga inde primum coepit; et iam nec lacus nec montes pauori obstabant; per omnia arta praeruptaque uelut caeci euadunt, armaque et uiri super alium alii praecipitantur. Pars magna, ubi locus fugae deest, per prima uada paludis in aquam progressi, quoad capitibus [umeris] exstare possunt, sese immergunt”), ou no pretérito imperfeito ("quae ubi immensa ac sine spe erat, aut deficientibus animis hauriebantur gurgitibus aut nequiquam fessi uada retro aegerrime repetebant atque ibi ab ingressis aquam hostium equitibus passim trucidabantur"').

Fica claro pela narrativa que Lívio planejou uma emboscada, e que os romanos foram surpreendidos. A clarividência e planejamento de Aníbal contrasta com o pânico e desordem vividos pelo exército romano nesta descrição. Logo no início do trecho, o historiador ressalta que os romanos perceberam pela audição que estavam cercados, e não pela visão. $O$ ataque inesperado provoca desordem nas linhas de batalha romanas. Em seguida o historiador menciona que não conseguiam ver por causa da névoa, e eram guiados mais pelos sons que pela visão, e isso provocou pavor em alguns. A descrição é de um combate caótico pelo lado romano, em que cada um era seu próprio general. E após a narrativa da morte do cônsul, a descrição é a de uma fuga desordenada, de soldados em pânico. O historiador enfatiza que alguns correram pra precipícios como se estivessem cegos (uelut caeci). Os soldados que 
escapam por um desfiladeiro também ficam sem saber o que acontecera com os outros, e somente com a luz do dia e com o fim da névoa o desastre é revelado. Assim, Lívio parece atribuir à cegueira física romana o sentido de cegueira também da mente, tomada de pânico, e refém da inteligência de Aníbal. Os romanos lutavam sem visão estratégica; a clarividência do cônsul parece ter sido cegada pela ânsia de combate e glória.

A cena é écfrástica porque a descrição é vívida e acontece presentificada aos nossos olhos, entretanto, é uma cena de obscuridades, de névoa e caos. A écfrase coopera assim para evidenciar tanto a capacidade estratégica de Aníbal como opor o momento de falta de estratégia romana. Essa falta será, entretanto, combatida na narrativa com a figura de Fábio Máximo, que estrategicamente evitará o combate direto com o cartaginês.

Após Trasimeno, Fábio Máximo assume o comando do exército, e utiliza a estratégia de marchar ao lado de Aníbal, mas sem iniciar o combate, o que ficou conhecido como método paralelo. Por isso, Fábio é chamado de Cunctator. Com tal estratégia, Fábio esperava que Aníbal começasse a sofrer dificuldades para conseguir mantimentos em terra alheia. Durante este período, o exército cartaginês viu-se certa vez encurralado por Fábio, que buscava impedir sua passagem por Casilino. Aníbal teria que ganhar as montanhas e passar por um desfiladeiro. Temendo que o exército romano o cercasse neste desfiladeiro, o general arma uma estratégia para assustá-los. Lívio descreve o estratagema em 22.16-17: Aníbal ordenou atear fogo em galhos de árvores atados a chifres de bois e soltá-los rumo às colinas. A correria dos bois criou uma cena assustadora aos romanos, que terrificados, não saíram do acampamento. $\mathrm{O}$ exercito cartaginês escapa então sem ser perseguido. Tal descrição mais uma vez ilustra a astúcia de Aníbal.

Lívio explica, entretanto, que ação de Fábio de evitar o confronto não era aprovada por todos e era vista por alguns como covardia, dentre os quais Minúcio, chefe da cavalaria. Aníbal, sabendo disso, provoca Minúcio para a luta, especificamente em um morro, terreno que colocaria o inimigo em desvantagem (22.28). Minúcio só não é totalmente derrotado pois Fábio vem socorrê-lo, e Aníbal recua. O episódio conta pontos para a tática de Fábio, também estrategista, que até então é o único que não fora vencido por Aníbal.

Mas com a eleição de novos cônsules, Terêncio Varrão e Emílio Paulo, Aníbal será descrito realizando a maior vitória até então, também graças a sua estratégia. Paulo seguia os conselhos de Fábio Máximo, de evitar o combate, mas Varrão é descrito como imprudente e precipitado (22.41.1). É Varrão quem marcha até Aníbal, em Canas, onde Aníbal já tinha montado acampamento visando uma situação vantajosa em batalha, uma vez que o vento 
Vulturno soprava ali pelas costas, e levantaria poeira diante dos olhos dos romanos (22.43.6; 46.9).

Estando os acampamentos armados dos dois lados da planície, Aníbal, vendo que o lugar era propício para seu combate, pois favorecia sua cavalaria, incitava o confronto. Lívio neste momento narra a discussão entre os dois cônsules, que representam dois modelos distintos de general: o precipitado e o cuidadoso. Paulo Emílio apresenta Semprônio e Flamínio como exemplos a não serem seguidos, e Varrão diz que a conduta de Fábio não é corajosa. ("cum Paulo Seempronique et Flamini temeritatem Varroni, Varro Paulo speciosum timidis ac segnibus ducibus exemplum Fabium obiceret”, 22.44.5-6). Na narrativa até esse momento o historiador claramente valeu-se destes dois modelos, sendo que general cauteloso teve sempre um destino melhor. Falaremos mais sobre isso adiante.

Varrão dá sinal de combate no dia de seu mando, e Aníbal posiciona sua linha de batalha de maneira estratégica, o que é descrito por Lívio minuciosamente em 22.46. Em 22.47, Lívio descreve os movimentos do combate, explicando como a linha cartaginesa, que se projetava no meio, foi cedendo e as laterais avançando, até que os cartagineses cercaram o exército romano. Lívio descreve ainda uma artimanha realizada pela cavalaria númida, que combatia coma ala esquerda romana (22.48). O historiador considera tal artimanha específica como uma a ação digna dos púnicos, com conotação negativa: um grupo de quinhentos númidas finge desertar, largando seus escudos, e juntam-se aos romanos, mas depois eles pegam escudos dos cadáveres e atacam os romanos pelas costas, cortando-lhes os joelhos por trás, provocando pânico e tumulto. Tal ataque por trás, cortando os tendões das pernas e impedindo-os de andar, parece ter sido escrita por outros autores latinos, de maneira que podemos pensar que era algo incomum, e talvez considerado cruel, uma vez que os debilitava sem provocar a morte rápida, pois na descrição da manhã seguinte do desastre alguns serão descritos ainda vivos, implorando pela morte. Ênio menciona o inimigo como ímpio e soberbo realizando tal ação (his pernas succidit iniquā superbiā Poeni, Enn. Ann. Fr 282 Warmington; 279 Vahl). Horácio provavelmente refere-se a esta ação na Ode 3.2.15: nec parcit imbellis iuventae poplitibus timidove tergo/ Nem aos moços perdoa, que covardes tímidas costas voltam ${ }^{204}$.

A cena da batalha é a de um massacre, pois estavam cercados. Em 22.49, Lívio narra a fala de Paulo, já ferido, recusando-se a fugir, e desejando morrer honrosamente em meio aos seus. Em seguida descreve que foi transpassado por uma lança. O historiador mostra então a fuga dos que conseguiram escapar do massacre, juntamente com o cônsul Varrão.

\footnotetext{
${ }^{204}$ Hor. Carm. 3.2.15. Tradução de E. Duriense.
} 
Embora a descrição dos movimentos da batalha, planejados por Aníbal, evidenciem sua inteligência militar, ela enfatiza a artimanha dos númidas como fraude, e o massacre com certa crueldade. Lívio fala sobre a gravidade desta derrota em 22.50.1-3, e depois, com a descrição do campo de batalha ao amanhecer, pinta o tamanho da desgraça romana:

Postero die, ubi primum inluxit, ad spolia legenda foedamque etiam hostibus spectandam stragem insistunt. Iacebant tot Romanorum milia, pedites passim equitesque, ut quem cuique fors aut pugna iunxerat aut fuga. Adsurgentes quidam ex strage media cruenti, quos stricta matutino frigore excitaverant volnera, ab hoste oppressi sunt; quosdam et iacentes vivos succisis feminibus poplitibusque invenerunt, nudantes cervicem iugulumque et reliquum sanguinem iubentes haurire; inventi quidam sunt mersis in effossam terram capitibus, quos sibi ipsos fecisse foveas obruentesque ora superiecta humo interclusisse spiritum apparebat. Praecipue convertit omnes subtractus Numida mortuo superincubanti Romano vivus naso auribusque laceratis, cum ille, manibus ad capiendum telum inutilibus, in rabiem ira versa laniando dentibus hostem exspirasset (Liv. 22.51.5-9).

No dia seguinte, assim que amanheceu, pararam para recolher os despojos e observar a carnificina, horrível até para o inimigo. Jaziam por toda parte milhares de romanos, soldados da infantaria e cavaleiros, reunidos pela fortuna, pela luta ou pela fuga. Alguns, ensanguentados, erguiam-se do meio da carnificina: acordaram com as feridas fechadas pelo frio da manhã e foram mortos pelo inimigo. Acharam outros deitados que estavam vivos, com as coxas ou joelhos cortados: descobriam a nuca e o pescoço implorando que derramassem o sangue restante. Alguns foram encontrados com a cabeça debaixo da terra; aparentemente haviam cavado, sozinhos, buracos e com a terra restante cobriram as faces e asfixiaram-se. Particularmente, impressionou a todos um númida retirado vivo debaixo de um cadáver romano, com o nariz e as orelhas dilaceradas: o romano, impossibilitado de carregar a espada com as mãos e enfurecido, morrera estraçalhando o inimigo com os dentes.

O campo de guerra no dia seguinte retrata o sofrimento romano, e o coloca diante dos olhos do leitor romano. A cena desperta a compaixão pelos romanos, e ajuda a pintar a imagem dos cartagineses como cruéis. Como no movimento de um olhar, o leitor é convidado a focar primeiramente todas as partes do massacre, os mortos em toda parte, e em seguida o sofrimento dos que ainda estavam vivos, aqueles que tiveram os jarretes cortados. Em seguida o foco diminui para imagem do soldado númida dilacerado pelo romano ensandecido. A cena é patética, e demonstra o alto grau de ódio e selvageria despertado num combate como esse. A cena horrível comove o leitor no sentido de compadecer-se dos romanos, e talvez possa contribuir para a opinião de Aníbal como cruel, embora a narrativa toda da batalha o caracterize mais uma vez como general inteligente.

$\mathrm{Na}$ descrição da batalha de Canas, a derrota romana parece ser vista novamente como resultado de um erro do cônsul, Varrão, no caso. O próprio historiador, dois livros depois, faz Quinto Fábio máximo discursar antes de uma eleição consular, e no discurso as derrotas de 
Trasimeno e Canas são exemplos de desastres ocorridos por causas de erros dos cônsules (24.7).

A temática da crueldade de Aníbal, atributo já sugerido no retrato do jovem Aníbal, é também abordada pelo historiador em descrições de ações, já mesmo anteriormente à narrativa da batalha de Canas. Logo após a narrativa da vitória louvável de Aníbal em Trébia, o historiador descreve a tomada de Victúmula por Aníbal, apontando vícios do general:

Postero die deditione facta praesidium intra moenia accepere; iussique arma tradere cum dicto paruissent, signum repente victoribus datur, ut tamquam vi captam urbem diriperent. Neque ulla quae in tali re memorabilis scribentibus videri solet praetermissa clades est: adeo omne libidinis crudelitatisque et inhumanae superbiae editum in miseros exemplum est. Haec fuere hibernae expeditiones Hannibalis (Liv. 21.57.13-14).

No dia seguinte, após a rendição, tomaram a guarnição que havia dentro das muralhas. Quando ordenavam que entregassem as armas e que prestassem obediência, repentinamente foi dado um sinal aos vencedores para que saqueassem a cidade como se essa tivesse sido capturada por força. E não foram omitidas as desgraças, que, numa situação como essa, costumam parecer aos escritores dignas de memória: de tal modo demonstrou toda forma de descontrole, crueldade e desumana soberba diante dos infelizes.

A ação de Aníbal e de seu exército é vista por Lívio como um exemplo de cobiça, crueldade e arrogância desumana. Após um breve comentário sobre a ordem cruel dada por Aníbal a seus homens na tomada de Sagunto, essa é a primeira vez que Lívio descreve Aníbal agindo com a crueldade mencionada no retrato de sua juventude. Segundo Levene, as ações de Aníbal anteriores a tal trecho foram bastante pias, e esta imoralidade será punida em seguida, através da tempestade descrita em $21.58^{205}$. Entretanto, a narrativa deste ato cruel do cartaginês é introduzida por "quae in tal ire memorabilis scribentibus videri solet", ressalva que lembra ao leitor que ele está diante de um informação contida em suas fontes, sendo que o próprio historiador frequentemente apresenta suas fontes como falíveis, e assim tal modalização pode lembrar ao leitor que ele está diante de um relato incerto ${ }^{206}$. Falaremos em breve sobre a interferência de outras vozes no texto e o retrato multifacetado de Aníbal.

Outra ação que evidencia a crueldade de Aníbal é narrada em 24.45.12-14, agora pela voz do historiador. Lívio relata que Aníbal queimou, viva, a família do traidor Dásio Altínio, por crueldade e cobiça (para parecer mais indignado pela traição do que ávido pelos seus bens):

Quibus nequaquam offensus Poenus, quia et ipsum ut ambiguae fidei virum suspectum iam pridem habebat et causam nactus erat tam ditis hominis bona possidendi vendendique; ceterum, ut irae magis quam avaritiae datum crederent homines,

\footnotetext{
${ }^{205}$ Levene (2010, 346).

${ }^{206}$ Cf. Moore $(2010,150)$.
} 
crudelitatem quoque aviditati addidit, coniugemque eius ac liberos in castra accitos, quaestione prius habita primum de fuga Altini, dein quantum auri argentique domi relictum esset, satis cognitis omnibus vivos combussit (Liv. 24.45.12-14).

De modo nenhum o cartaginês estava indignado com tais ações, pois já há algum tempo considerava o homem suspeito e de lealdade duvidosa, e surgia um motivo para tomar e vender os bens de um homem tão rico. Então, para que os homens acreditassem que agia mais pela ira que pela avareza, somou a crueldade à cupidez: chamou a esposa e os filhos do traidor e perguntou-lhes primeiro acerca da fuga de Altino, e depois sobre a quantidade de ouro e prata que havia em casa. Tendo sabido suficiente, queimou-os vivos.

Aníbal, segundo o historiador, manda executar a família com o pretexto de que estava irado com a traição de Altínio, sendo que a causa real era a cobiça, já que Aníbal se apossaria dos bens do traidor. $\mathrm{O}$ historiador considera cruel e gratuito a maneira pela qual foram mortos. A cobiça e ambição de Aníbal será mais frequentemente tematizada na narrativa após a batalha de Canas, como veremos. Em outro episódio o leitor também vê Aníbal, já no fim da guerra, agindo de maneira cruel. Em 30.20.6, Lívio relata que o cartaginês assassina uma quantidade grande de seus homens, nativos da Itália, que se recusaram a embarcar para África e se refugiaram no templo de Juno Lacínia:

[...], multis Italici generis, quia in Africam secuturos abnuentes concesserant in Iunonis Laciniae delubrum inviolatum ad eam diem, in templo ipso foede interfectis.

Muitos soldados de origem latina que se recusaram a seguir para África haviam se escondido no templo de Juno Lacínia, não violado até aquele dia, e foram assassinados cruelmente ali mesmo.

Até o momento, as ações de Aníbal descritas pela auctoritas do historiador o caracterizaram como grande general, sobretudo em estratégia, e também como cruel em alguns momentos. Lívio parece opor na narrativa dois padrões distintos de comportamento: o do comandante precipitado e imprudente (Semprônio, Flamínio, Minúcio e Varrão), e o do comandante arrazoado e inteligente (Aníbal, Fábio e Emílio Paulo). As estratégias de Aníbal, que não parecem ser vistas como criminosas pelo historiador nas principais batalhas (com exceção da artimanha da cavalaria númida em Canas), justificam as vitórias sobre comandantes precipitados. Esta ideia, já indicada pela não derrota de Fábio Máximo, será também confirmada pelo agir de Cipião Africano, como veremos.

Mas após Canas Lívio parece construir um Aníbal que teve sua capacidade estratégica um pouco cegada por alguns vícios. Como veremos, seu caráter não é uno ao longo da narrativa; o próprio retrato de sua juventude já apontava para uma ambiguidade de virtudes e vícios. Levene nos adverte que é errôneo tentar extrair de várias passagens uma personalidade 
única, pois é preciso ver cada caráter de acordo com o papel que ele interpreta no sistema de interações com outros caracteres, e mais amplamente diante do pregresso da guerra como um todo ${ }^{207}$. Assim, o caráter parece variar conforme o contexto; seu caráter será retratado de forma mais viciosa quando é necessário para justificar sua trajetória de decadência após Canas. Alguns vícios do general, que levam a decisões erradas, parecem justificar o declínio dos cartagineses na guerra. Além disso, em alguns momentos o caráter de Aníbal será também construído por oposição a de outros romanos virtuosos, sobretudo, como veremos, Cipião Africano.

É preciso salientar que Lívio não apresenta nunca de forma muito clara as causalidades que regem os acontecimentos. Levene, comparando as explicações dos acontecimentos, vitórias e derrotas, de Políbio e Lívio, explica que o Lívio altera o sistema causal polibiano racionalista e centrado no comandante. Para Levene, Lívio acrescenta à narrativa causalidades morais e religiosas, apresentando várias alternativas para explicar um evento ${ }^{208}$. Assim, identificamos algumas explicações para a derrota cartaginesa que parecem ser sugeridas pela narrativa: a demora de Aníbal após Cannas, e a estadia do exército em Cápua.

Logo após o relato da vitória em Canas, Lívio o descreve mais preocupado com a venda dos prisioneiros do que com a vitória sobre os romanos. A cobiça parece cegar sua estratégia militar, que deveria o fazer avançar imediatamente a Roma. Em 22.52, Tito Lívio diz relata que os cartagineses ficam recolhendo despojos após a batalha, e dedicam-se a atacar um acampamento romano, exigindo a entrega de armas, cavalos e denários. Em 22.58, afirma que Aníbal estava mais preocupado com tarefas de um vitorioso do que de alguém que ainda estava em guerra, e descreve como não adequada a negociação que Aníbal faz com os cativos romanos. Já antes deste comentário, Lívio o pinta como ávido por dinheiro através do discurso de outras personagens. Públio Semprônio Tuditano, tribuno militar, assim discursa entre os fugitivos da batalha de Canas:

"Capi ergo mavoltis", inquit, "ab avarissimo et crudelissimo hoste aestimarique capita vestra et exquiri pretia ab interrogantibus Romanus civis sis an Latinus socius, ut ex tua contumelia et miseria alteri honos quaeratur?" (Liv. 22.50.6-7).

"Então preferis ser capturado pelo mais avarento e cruel dos inimigos e ter vossas cabeças avaliadas e preços fixados pelos que perguntam se és cidadão romano ou aliado latino, de modo que honrarias são obtidas a partir do ultraje e desgraça do outro?"

\footnotetext{
207 Levene (2010, 186).

${ }^{208}$ Levene (2010, 291).
} 
Com tal discurso, o tribuno motiva seus soldados a fugirem alertando que Aníbal, avarissimo e crudelissimo, iria capturá-los e comercializá-los. A carta de Varrão ao Senado, solicitando resgate, pinta um Aníbal corrompido após Canas:

[...] Poenum sedere ad Cannas in captivorum pretiis praedaque alia nec victoris animo nec magni ducis more nundinantem (Liv. 22. 56.3).

[...] o cartaginês estava sentado em Canas negociando os preços dos cativos e de outros despojos, sem o valor de um vencedor e o caráter de um grande comandante.

O discurso descreve Aníbal sentado, estagnado. O verbo sedere, sentar-se, contrasta com movimento de marcha a Roma que Aníbal deveria estar comandando. O termo usado para a negociação de Aníbal é pejorativo. O verbo nundinor, segundo Oxford Latin Dictionary, é usado para designar um comércio irregular e indecente ${ }^{209}$. Assim, nas palavras do inimigo, Aníbal agia de maneira não digna de um grande general.

As negociações de resgate tentadas por Aníbal não evidenciam apenas o vício da cobiça, mas correspondem também a um erro estratégico, pois ocasionam uma demora que, segundo a narrativa, permitiu que Roma se salvasse (Mora eius diei satis creditur saluti fuisse urbi atque imperio, 21.51.4). Se Aníbal tivesse marchado imediatamente a Roma, tomaria a cidade, desguarnecida, com certa facilidade. Mas sua demora permite que os romanos se organizem novamente. Assim, tal cobiça é como uma paixão que cega o raciocínio de Aníbal. Logo após a narrativa do fim do combate, Lívio reporta a fala de Maharbal sobre o fato de Aníbal não querer marchar imediatamente a Roma: "Nom omnia nimirum eidem di dedere: vincere scis, Hannibal, victoria uti nescis". Certamente os deuses não concederam todas as coisas a um mesmo homem: sabes vencer, Aníbal, mas não sabes aproveitar a vitória" (22.51.4). Segundo Lívio, o próprio Aníbal reconhece depois que deixou passar esta grande oportunidade (26.7.3-4). A descrição de sua amargura ao deixar a Itália também mostra um Aníbal arrependido:

Respexisse saepe Italiae litora, et deos hominesque accusantem in se quoque ac suum ipsius caput exsecratum, quod non cruentum ab Cannensi victoria militem Romam duxisset (Liv.30.20.7-8).

Voltou-se muitas vezes para olhar a costa da Itália, e acusando deuses e homens, amaldiçoou a si e a sua própria cabeça, por não ter conduzido a Roma seu exército sedento de sangue após a vitória em Canas.

Interessante ressaltar que nem Políbio nem Apiano comentam sobre a demora de Aníbal. Segundo Moore, Lívio deve ter retirado tal anedota de Célio Antípater, que por sua

$\overline{{ }^{209} \text { Oxford Latin Diccionary }}(1968,1206)$. 
vez teria tido por fonte Catão ${ }^{210}$. Assim, Lívio incorporaria tal anedota transformando-a em uma possível causa da decadência cartaginesa.

Neste momento da narrativa, Lívio contrasta as ações cobiçosas cartaginesas com a atitude virtuosa romana que foi a decisão do Senado por não pagar o resgate dos prisioneiros da guerra de Canas. Através do discurso de Mânlio Torquato (22.60), o Senado convence-se de que não deveriam ceder ao desejo de Aníbal e resgatar aqueles que, em vez de combaterem gloriosamente até a morte, fugiram. Chaplin defende este momento em que Roma opta pela virtude inicia uma mudança de Fortuna, tanto para os romanos quanto para os cartagineses ${ }^{211}$. Além do atraso para marchar até Roma, Lívio parecer considerar a estadia do exército cartaginês em Cápua também como um erro estratégico de Aníbal. O cartaginês marcha a Roma, mas como havia se demorado, houve tempo para outro exército fosse reunido. Diante de Roma guarnecida, Aníbal decide passar o inverno em Cápua. A cidade é descrita pelo historiador como corrupta e licenciosa:

Inde Capuam flectit iter luxuriantem longa felicitate atque indulgentia fortunae, maxime tamen inter corrupta omnia licentia plebis sine mode libertatem exercentis (Liv. 23.2.1)

De lá seguiu para Cápua, cidade que, há tempo, gozava de prosperidade e de uma fortuna favorável; todavia, excessivamente mergulhada em todos os vícios e de uma licenciosidade da plebe de maneira tal que exerciam a liberdade sem limite algum.

Em outros trechos Lívio também pinta Cápua como lugar de vícios, e para o historiador os costumes da cidade foram prejudiciais ao exército ("banquete deu-se de maneira não adequada ao costume púnico e à disciplina militar"23.8.6”). Em 23.18.10-16, Lívio descreve o afrouxamento da disciplina sofrido, e diz que este erro foi ainda maior do que a demora de Aníbal após Canas:

Ibi partem maiorem hiemis exercitum in tectis habuit, adversus omnia humana mala saepe ac diu duratum, bonis inexpertum atque insuetum. Itaque, quos nulla mali vicerat vis, perdidere nimia bona ac voluptates immodicae, et eo impensius quo avidius ex insolentia in eas se merserant. Somnus enim et vinum et epulae et scorta balineaque et otium consuetudine in dies blandius ita enervaverunt corpora animosque ut magis deinde praeteritae victoriae eos quam praesentes tutarentur vires, maiusque id peccatum ducis apud peritos artium militarium haberetur quam quod non ex Cannensi acie protinus ad urbem Romanam duxisset; illa enim cunctatio distulisse modo victoriam videri potuit, hic error vires ademisse ad vincendum. Itaque hercule, velut si cum alio exercitu a Capua exiret, nihil usquam pristinae disciplinae tenuit. Nam et redierunt plerique scortis impliciti, et, ubi primum sub pellibus haberi coepti sunt, viaque et alius militaris labor excepit, tironum modo corporibus animisque deficiebant, et deinde per omne aestivorum tempus magna pars sine commeatibus ab signis dilabebantur, neque aliae latebrae quam Capua desertoribus erant (Liv.23.18.10-16).

\footnotetext{
${ }^{210}$ Moore (2010, 156).

${ }^{211}$ Cf. Chaplin (2000).
} 
O exército, formado por soldados endurecidos por todo tipo de maldades humanas no decorrer de muito tempo e desacostumados a coisas boas, Aníbal manteve a maior parte do inverno dentro de casas. E então, aqueles que nenhuma força e perigo haviam vencido, as coisas boas em excesso e os prazeres desmedidos arruinaram. E, pela falta de hábito, mais inclinados e mais ávidos se tornavam à medida que mergulhavam nestes vícios. Pois o sono, o vinho, os banquetes, as prostitutas, os banhos e o ócio, com o costume, dia a dia brandamente enervavam os corpos e as mentes, de maneira que os homens apegavam-se mais às vitórias passadas do que ao presente. Este erro do comandante é considerado pelos peritos na arte militar maior que aquele de não ter marchado a Roma imediatamente após Canas: aquela demora, naquele momento, podia parecer que apenas retardava a vitória, mas esse erro impediu os homens de vencerem. E assim, por Hércules, tendo partido de Cápua com outro exército, nunca mais alcançou aquela antiga disciplina. Pois muitos regressaram a Cápua, enlaçados por prostitutas. Logo que começaram a dormir em tendas e a marcha e outras tarefas militares os apanharam, cansavam-se física e moralmente, como se fossem soldados recrutas. Em seguida, durante todo o tempo de estio, grande parte, sem permissão, escapava das tropas, e não havia outro esconderijo para os desertores além de Cápua.

A mesma ideia é apresentada também no discurso de Marcelo, em 23.45, no qual o general encoraja seus homens antes do combate em Nola; argumentando que os soldados de Aníbal foram todos amolecidos pelas delícias de Cápua. Segundo a personagem romana, “Cápua fora a Canas de Aníbal”. E, realmente, Aníbal é derrotado neste enfrentamento.

Aníbal parece ter, segundo a narrativa, uma parcela de culpa em tal afrouxamento do exército. Além de escolher Cápua, Aníbal não é descrito exercitando seus homens, diferentemente de outros generais romanos, como o cônsul Tibério Semprônio, que, alguns parágrafos depois, é descrito obrigando seus homens a se exercitarem no acampamento em Literno para que não se desfalecessem em ócio (23.35). Em 27.3.2, Fúlvio, depois de ter capturado Cápua, remove seus soldados de lá temendo tal afrouxamento. Lívio relata que Cipião exercitava seus homens durante a estadia em Nova Cartago (26.51).

Outra questão interessante é que Políbio não parece ver a estadia em Cápua como um momento de corrupção do exército. No início do livro 7, o historiador grego apenas menciona que Cápua, uma cidade acostumada à abundancia por causa dos solos férteis, era dada à luxúria e extravagancias, e que, com dificuldades de manter tal prosperidade, aliaram-se a Aníbal. Não há em seguida a explicação de que o exército lá se corrompera, pelo menos não nos fragmentos que nos restaram. Para Políbio, a causa do declínio cartaginês parece ter sido o enfraquecimento das alianças de Aníbal após a retomada de Cápua pelos romanos (Plb.9.26.2-9). Cornélio Nepos, também autor anterior a Lívio, também nada comenta sobre a estadia em Cápua como um erro ou como um momento de degeneração moral. Assim, Lívio parece preferir neste momento uma causalidade moral para explicar as futuras derrotas cartaginesas. 
A questão está integrada à discussão sobre a causalidade na obra de uma modo geral. Por um lado, a explicação causal moral está de acordo com a ideia, expressa no Prefácio, de que a história é determinada pelos indivíduos. A narrativa é, entretanto, ambígua diante da influência da religião; em alguns casos o autor atribui à pietas de uma personagem ou a sua falta um sucesso ou fracasso. Por outro lado, Lívio racionaliza às vezes relatos miraculosos, e atribui responsabilidade humana aos fatos ${ }^{212}$. Segundo Levene, o favor e a ira divina em relação ao comportamento moral e religioso, e a recompensa ou punição, são sim um importante subtexto para entender muitos dos eventos da Terceira Década, mas Lívio não é muito explícito em relacionar imoralidade e punição com sua própria voz, isso é geralmente diluído nos discursos de personagens. Mas é muito frequente a justaposição de imoralidade e insucesso, sem que haja uma ação divina de punição por trás. Segundo Levene, sem a concepção religiosa, ficamos com um senso vago de que imoralidade e moralidade - pelos menos em alguns momentos, estão ligados casualmente ao sucesso e insucesso; mas a natureza desta conexão é sempre opaca ${ }^{213}$. Levene assim conclui seu estudo sobre a causalidade na Terceira Década:

His self-presentation centres on showing himself as a provider of ethical lessons, and, as I demonstrated in this chapter, he highlights his presentation of causation in ethical terms, and the reader is forced to interpret it in those terms not least because it is so hard to make sense of it in any other terms. Livy's world is an ethical world: it is also a real world. But the real world is one where causal sequence, chronology, human behavior and everything else are subordinated to the moral structure that Livy offers, and which he implies is also the moral structure of the universe. Ethics effectively controls everything else. The ultimate understanding of how Livy can present his text, with its selfacknoledge contradictions, as if it were reality, may be that he regards the moral picture that his text presents as a valid account in its own right, but also an accurate demonstration of the way the world works. By reading through Livy's texts one learns its moral lessons - complex and contested though they are - and one is obliged to focus on morality precisely because there is no other way of making sense of that text. And it is in those lessons, for him, that the truth of the Hannibalic Wars resides ${ }^{214}$.

Assim, diante da predominância da motivação moral no sistema de causalidade da obra, Cápua parece sim justificar a mudança de Fortuna cartaginesa. Mas o episódio reitera também uma ideia importante para o autor: a de que uma sociedade que atingiu seu ápice, vive em abundância, cria seu próprio colapso. Lívio provavelmente está falando também da sua própria pátria, da Roma da época das guerras civis, de uma degradação dos costumes da qual Augusto, com seu projetos de restauração moral, seria a solução.

\footnotetext{
${ }^{212}$ Cf. Ogilvie $(2000,164)$.

${ }^{213}$ Cf. Levene (2010, 344-7).

${ }^{214}$ Levene (2010, 392).
} 
Como vimos, falas de inimigos de Aníbal o pintaram como cruel e cobiçoso. Mas mesmo antes dos acontecimentos da batalha de Canas e da estadia em Cápua, discursos de outras personagens (grande parte vozes de inimigos de Aníbal) já buscavam ofuscar a imagem clara de um general grandioso e estrategista, mesmo nos livros 21 e 22, nos quais o cartaginês vive uma trajetória ascendente e suas ações gloriosas são descritas pelo historiador. Logo no início do livro 21, Anão, líder do partido político adversário dos Barcas, retrata Aníbal como alguém com "ânsia de comando", cupidine regni, gênio maligno e incitador da guerra (21.10). $\mathrm{O}$ vitupério neste trecho parte da boca de um inimigo político do partido de Aníbal. Lívio, assim, relativiza a acusação, apresentando pontos de vistas diferentes sobre o comandante, deixando para o leitor tirar suas próprias conclusões. Timothy J. Moore ${ }^{215}$ aponta que outras acusações e relatos que a tradição faz sobre os Barcas são alocados por Lívio em discursos do inimigo político Anão. Segundo o estudioso, em 21.2.3-4, Lívio menciona a história que alguns contam (uti ferunt) que Amílcar agradou-se sexualmente de seu cunhado Asdrúbal, e depois Lívio relata o discurso de Anão que reforça o boato, deixando claro assim que tal história, provavelmente repetida pela tradição historiográfica hostil aos cartagineses, era fruto de rumores anti-Barcas.

Lívio reporta o discurso de Cipião, pai do Africano, antes da batalha do Ticino, apresentando também uma caracterização indireta de Aníbal. O questionamento de se seria Aníbal sobre-humano por causa da passagem pelos Alpes, e se poderia ser comparado a Hércules aparecem como questionamentos nas palavras do inimigo.

"Experiri iuvat utrum alios repente Carthaginienses per viginti annos terra ediderit, an idem sint qui ad Aegates pugnaverunt insulas et quos ab Eryce duodevicenis denariis aestimatos emisistis, et utrum Hannibal hic sit aemulus itinerum Herculis, ut ipse fert, an vectigalis stipendiariusque et servus populi Romani a patre relictus. Quem nisi Saguntinum scelus agitaret, respiceret profecto si non patriam victam domum certe patremque et foedera Hamilcaris scripta manu, qui iussus ab consule nostro praesidium deduxit $a b$ Eryce, qui graves impositas victis Carthaginiensibus leges fremens maerensque accepit, qui decedens Sicilia stipendium populo Romano dare pactus est" (Liv. 21.41.6-9).

“Agrada-nos confirmar se acaso em vinte anos a terra repentinamente deu à luz a outros cartagineses, ou se são os mesmos que lutaram nas ilhas Égates, os quais vós despedistes de Érice avaliados em dezoito denários; e se acaso este Aníbal é um êmulo de Hércules, como ele mesmo diz, ou um devedor, contribuinte e escravo do povo romano deixado pelo pai. Se o crime dos Saguntinos não o tivesse excitado, ele, enquanto, enquanto partia, talvez teria se lembrado de sua pátria vencida e certamente de sua casa e pai, e do tratado escrito pela mão de Amílcar, que, comandado pelo nosso cônsul, retirou as guarnições de Érice e, pesaroso e queixoso, aceitou leis pesadas impostas aos cartagineses vencidos e, retirando-se da Sicília, concordou em pagar tributo ao povo romano".

\footnotetext{
${ }^{215}$ Moore (2010, 159).
} 
Esse discurso sucede a passagem de Aníbal pelos Alpes, e a descrição que o historiador faz sobre as condições precárias do exército após tal proeza. Criando um discurso de Cipião, o historiador deseja ficcionar qual seria o pensamento a a expectativa dos romanos após a passagem de Aníbal pelos Alpes. Cipião diz que eles já estariam enfraquecidos pela passagem e que a vitória era certa para ele. O discurso de Cipião revela que o general subestimou seu inimigo. Aníbal e os cartagineses são comparados aos vencidos e humilhados da primeira guerra púnica no discurso. Incluindo tal discurso direto, o historiador situa a vitória de Aníbal em Ticino como uma prova de que tais cartagineses não são como esses que Cipião descreve em seu discurso. O discurso, vitupério, e a ação seguinte que o contraria, funcionam juntos como um louvor de Aníbal e seu exército.

Outro ponto interessante que se pode analisar no trecho é o boato de que Aníbal almejava ser Hércules. Uma relação entre Aníbal e Hércules já havia sido introduzida pelo historiador em 21.21, ao descrever o general como cumprindo votos a Hércules antes da marcha à Roma. O discurso de Cipião trata como boato o desejo de Aníbal de ser como Hércules, associação que provavelmente era feita diretamente devido à passagem pelos Alpes. Esta associação será também comum na literatura posterior. Marcial situa o local do juramento infantil de Aníbal em um altar de Hércules em Cartago no epigrama 9.43.9, e no seguinte diz terem sido Aníbal e Alexandre os antigos donos de uma estatueta de Hércules agora em posse de seu amigo. Sílio Itálico, poeta do período flaviano, constrói a personagem Aníbal explicitamente como um êmulo de Hércules em sua epopeia Punica ${ }^{216}$.

Na numismática, há também um indício dessa relação. Na época em que a família Barca comandava a Espanha, houve uma série de moedas que associava a família ao deus Melqart, que era o deus fenício associado ao Héracles grego. $\mathrm{Na}$ figura 1 (anexo), apresentamos um exemplar dessa série. De um lado, está figurado Melqart-Héracles, com um taco sobre o ombro (comum na representação do herói), e do outro, um homem, com vestimenta púnica, conduzindo um elefante. Embora não se possa dizer exatamente se o homem é Amílcar ou Aníbal, podemos concluir que a associação entre Melqart-Hércules e família Barca era algo programado enquanto esta estava no comando da Espanha.

Seja fruto de uma prerrogativa de Aníbal a si ou fruto do medo dos romanos, a comparação com o herói grego cooperava para a imagem de Aníbal como divino e invencível. A comparação com Hércules exalta as qualidades bélicas de Aníbal, pois aquele representava o ideal heroico da força e resistência. No discurso de Cipião, o historiador colocar em dúvida

${ }^{216}$ Cf. Asso (2010). 
esta equivalência, que parece se confirmar até Canas, mas no final, com a vitória romana, expõe a inferioridade de Aníbal diante de Hércules.

Outro trecho demonstra claramente como o historiador isenta-se de posicionar-se diante de histórias, provavelmente que circulavam como boatos, sobre Aníbal. O historiador aloca no discurso do cônsul Terêncio Varrão - um discurso com o claro intuito de convencer os delegados de Cápua a não aliarem-se ao lado cartaginês - o relato de que Aníbal fazia pontes com corpos, incitava o canibalismo, entre outras crueldades:

[...] Poenus hostis, ne Africae quidem indigena, ab ultimis terrarum oris, freto Oceani Herculisque columnis, expertem omnis iuris et condicionis et linguae prope humanae militem trahit. Hunc natura et moribus immitem ferumque insuper dux ipse efferavit pontibus ac molibus ex humanorum corporum strue faciendis et, quod proloqui etiam piget, vesci corporibus humanis docendo (Liv. 23.5.11-12).

O cartaginês, nosso inimigo, por certo traz soldados nem ao menos de origem africana, mas dos últimos limites da terra, do estreito do Oceano e das colunas de Hércules, que pouco conhecem do Direito, das convenções e têm língua precariamente humana. Esses, selvagens em natureza e costumes, o próprio comandante tornou ais violentos com a construção de pontes e passagens de corpos humanos empilhados, e ao aconselhá-los a comer carne humana, o que é repugnante até de se relatar.

O cônsul vale-se do estereótipo do bárbaro e selvagem para caracterizar os soldados de Aníbal oriundos de vários lugares. Tal esteriótipo pode estar apoiado numa tradição mais antiga, de descrição de povos desconhecidos, à maneira do que faz Heródoto em suas Historias, que contém exposições sobre povos bárbaros e seus costumes, como os egípcios (2.35) e citas (4.1-44). Os povos mais dos lugares distantes são considerados bárbaros por oposição à civilização grega, e no caso de Lívio, à romana. A linguagem elaborada, o conhecimento do Direito e das convenções sociais, caracterizam uma cidade como civilizada; Roma é o padrão, e tais povos distantes, longe destas características, são considerado ainda mais bárbaros que os africanos.

Embora Varrão esteja aplicando este estereótipo uma parcela do exército e não a Aníbal, com a acusação de que Aníbal os piorou fica evidente que há também uma diferença entre Aníbal e o ideal romano representado por Varrão, que o recrimina por tê-los tornado ainda mais violentos. A sugestão de canibalismo pretende enquadrar Aníbal também como um bárbaro. Entretanto, essa é a voz da personagem. O retrato do estrangeiro, principalmente daquele dos lugares mais distantes, como não civilizado como o romano, é mediado entretanto por um discurso tendencioso de uma personagem, e ainda uma personagem que não tem mais a simpatia. Lívio, no decorrer de sua obra, frequentemente distingue cartaginês e bárbaro, e a 
oposição entre romano e bárbaro e romano e cartaginês é complexa e variada ao longo da obra $^{217}$.

As acusações dispostas no discurso do cônsul eram provavelmente boatos que circularam na época ou histórias comuns na Historiografia. Segundo Levene, há inúmeras outras fontes sobre a acusação de que Aníbal construía pilhas de corpos e favorecia o canibalismo, de maneira que parece ter havido um ou mais predecessores de Lívio que relatam tais histórias. A ponte de corpos é também mencionada por Valério Máximo 9.2, Sílio Itálico 8.6689, Floro 1.22.18 e Apiano, Punica, 63. Políbio relata que Monômaco tentou convencer Aníbal de que o único jeito de lutar na Itália era praticando o canibalismo, mas que Aníbal não conseguiu persuadir nem a si nem a seus homens a fazê-lo (Plb. 9.24.1-8).

Diante disso, parece-nos que Tito Lívio parece construir um Aníbal menos vicioso que o de outros autores, ou pelo menos mais ambíguo. Moore ${ }^{218}$ acredita que a tradição historiográfica romana era majoritariamente hostil a Aníbal, uma vez a tradição analística começa com autores que lutaram na guerra contra o cartaginês. Lívio entretanto, teria tido acesso a uma exceção, Célio Antípater, que teria se baseado no pró-Aníbal Sileno, e por isso feito um retrato um pouco menos negativo que os de outros analistas.

O Aníbal de Políbio é também complexo; o historiador trata de seu caráter em 9.22-26 e afirma que é muito difícil estabelecer a verdade sobre ele. Para Políbio, as ações de Aníbal são resultado da influência de amigos e das circunstâncias, que o obrigou a agir às vezes com violência e quebrar alianças, o que teria gerado acusações de crueldade e perfídia. Um episódio que em Políbio caracteriza Aníbal como cruel é a pilhagem de parte do território romano após a batalha de Trasimeno. Políbio relata que Aníbal, passando por Umbria e Piceno, matou um grande número de pessoas na estrada, e na captura das cidades, ordenou assassinar todos os adulto que caíssem em suas mãos (Plb. 3.86.11). Lívio, no entanto, fala sobre a devastação deste território sem nada mencionar sobre mortes (22.9.1-5). É muito provável, entretanto, que Políbio não tenha sido uma fonte de Lívio na Terceira Década ${ }^{219}$.

Fora da tradição historiográfica, Aníbal parece ter sido estereotipado como cruel e vicioso. Cícero, em De Amicitia, 28, afirma que Roma sempre odiará Aníbal por causa de sua crueldade ("alterum propter crudelitatem semper haec civitas oderit”). Horácio demonstra o ódio romano pelo general no Epodo 18.8 (parentibusque abominatus Hannibal). Sêneca, em De Ira, 2.5.4, apresenta Aníbal como exemplo de quando o indivíduo, tomado de ira, desvencilhado de misericórdia e de vínculo humano, tem prazer na crueldade:

\footnotetext{
${ }^{217}$ Cf. Levene $(2010,220)$.

${ }^{218}$ Moore $(2010,140)$.

${ }^{219}$ Cf. Levene (2010, 127-31).
} 
Hannibalem aiunt dixisse, cum fossem sanguine humano plenam vidisset: "O formonsum spectaculum!" Quanto pulchrius illi visum esset, si flumen aloquod lacumque complesset! Quid mirum, si hoc máxime spectaculo caperis innatus sanguini et ab infante caedibus admotus? Sequete te fortuna crudelitati tuae per vinginti anos secunda dabitque oculis tuis gratum ubique spectaculum; videbis istud et circa Trasumennum et circa Cannas et novissime circa Carthaginem tuam.

Dizem que Aníbal quando viu a trincheira cheia de sangue humano exclamou: "Que belo espetáculo!" Quão mais formosa teria sido para ele a visão se tivesse preenchido um rio ou um lago! Que maravilhoso se contemplasses esse grande espetáculo, tu, nascido em meio ao sangue e desde criança acostumado a assassinatos? A Fortuna atenderá a tua crueldade por vinte anos e dará aos teus olhos um espetáculo satisfatório: o verás em Trasimeno, em Canas, e depois maravilhosamente em tua Cartago! ${ }^{220}$

Aníbal é retratado por Sêneca como cruento. Trata-se de um tratado filosófico, já do século primeiro, e Sêneca utiliza um exemplo conhecido, Aníbal, que deveria ter a fama de cruel entre a audiência da obra, para ilustrar o prazer de alguns no ódio. Embora talvez Sêneca exagere um pouco, para que o exemplo seja verossímil é preciso que Aníbal já tivesse fama de cruel.

Plínio, Velho, menciona que há uma famosa história (não mencionada por Lívio, entretanto) de que Aníbal obrigou um romano prisioneiro a lutar sozinho contra um elefante, prometendo-lhe a liberdade (H. N. 8.18). O autor relata ainda que o cartaginês matou o romano em seguida, mesmo este tendo vencido o elefante. Assim, é provável que histórias como essa, ilustrando a crueldade de Aníbal, tenham circulado em Roma, sejam elas baseadas em fatos ou não.

Em Juvenal, Aníbal é considerado o pior inimigo de Roma (Sat., 6.290), e Suetônio conta uma anedota que ilustra como sua imagem era ainda de temível:o biógrafo conta que Domiciano mandou executar um senador que além de possuir o mapa do mundo conhecido e andar com discursos dos generais de Tito Lívio, dera a seu dois escravos os nomes de Magão e Aníbal (Vida de Domiciano, 10.3). Tal anedota demonstra como a admiração do general era uma ameaça e como Aníbal e suas lições eram perigosas. Por outro lado, ela sugere também que Aníbal poderia também ser admirado por um romano daquele período. Suetônio expõe assim a ambiguidade que a figura de Aníbal poderia conter. Outra obra, bem posterior, ilustra a ambiguidade da figura de Aníbal. Luciano, em Diálogos dos mortos, faz Aníbal, Alexandre e Cipião competirem pelo posto de melhor general ${ }^{221}$. No discurso de Aníbal, há argumentos a favor de Aníbal como grande general, e no de Alexandre, Aníbal é descrito como cruel e trapaceiro. Aníbal é entretanto colocado em terceiro lugar por Minos.

\footnotetext{
${ }^{220}$ Sen. De Ira 2.5.4 (Tradução nossa).

${ }^{221}$ Luciano, DMort.380-398.
} 
Lívio, assim, contrariamente à historiografia analística, parece construir um retrato de um Aníbal mesmo vicioso. A criação de seu retrato através de várias vozes relativiza acontecimentos graves, e coopera para a construção de uma imago ambígua. Além do discurso das personagens, outra estratégia é utilizada pelo historiador para apresentar incertezas sobre acontecimentos: a divergência entre as fontes. Por exemplo, ainda no livro 21, tratando do início da guerra, Lívio apresenta versões divergentes, obtidas por suas fontes, sobre a cronologia dos acontecimentos que antecederam o ataque a Sagunto, dificultando assim concluir se é verdadeira a acusação romana de que Aníbal ignorou os embaixadores enviados a Cartago e quebrou o tratado entre os povos (21.15). Lívio não concorda nem discorda da acusação de parte da tradição historiográfica anterior de que Aníbal entrara em guerra sozinho, sem o respaldo do Senado cartaginês ${ }^{222}$. Em outros momentos, o historiador posiciona-se mais claramente diante de suas fontes, optando por uma delas ou acrescentando a sua própria. Em 23.19.16-18, por exemplo, Lívio afirma que Aníbal cumpriu com lealdade o acordo de libertar os habitantes de Casilino que se entregaram, e que esta versão é mais verdadeira do que a que diz que foram massacrados. O historiador, dessa maneira, parece relativizar relatos sobre exageros de Aníbal, talvez por considerar que eram exageros dos outros autores. Segundo Moore, Lívio às vezes relata que tal fonte diz algo, mas algumas páginas antes o historiador questionara tal fonte. Assim, segundo Moore, Lívio instaura polêmicas entre suas fontes, e as torna pouco confiáveis. O retrato de Aníbal criado por tais fontes deve, portanto, ser considerado não como visão do historiador, mas no máximo um indício ${ }^{223}$.

\subsection{A decadência de Aníbal e a ascensão de Cipião Africano}

Até o momento, nos detivemos mais nos primeiros livros da terceira década. Vimos que Aníbal inicia uma trajetória ascendente, de seguidas vitórias, e que seu êthos é construído através de ações mostradas e de caracterizações diretas e indiretas como um grande general, sobretudo estrategista, mas que provavelmente cometera algumas ações cruéis. A partir de Canas, como vimos, Lívio parece sugerir que Aníbal errara estrategicamente, por sua demora, devido à cobiça, e pela estadia em Cápua. Após tal inverno, Aníbal luta contra o pretor Cláudio Marcelo em Nola, e é derrotado duas vezes $(23.16$; 23.44). Concomitantemente a estes acontecimentos relatados, os cartagineses começam a perder batalhas para Cipião

\footnotetext{
222 Moore (2010, 149).

223 Moore (2010, 142-5).
} 
algumas batalhas em território hispânico (livro 24). Além disso, o exército de Anão é derrotado por Tibério Graco em Benevento (24.17).

No início do livro 25, Aníbal perde alguns povos aliados, mas toma a cidade de Tarento (25.9), com estratégia, e mata somente romanos, e também vence facilmente os homens do centurião Marco Centênio Pênula, que o historiador qualifica como inexperiente (25.19). Em seguida, vence as legiões do pretor Cneu Fúlvio em Hedônia. Neste mesmo livro, estão relatadas as vitórias de Lúcio Márcio sobre os exércitos de Asdrúbal e Magão na Hispânia, e ainda a tomada de Siracusa por Marcelo. No início do livro 26, Lívio narra a retomada de Cápua pelos romanos; Aníbal tenta defender seu aliado com seu exército, mas desiste. Nesta ocasião, uma artimanha sua é descoberta (26.6). Para Lívio, Aníbal abandonou Cápua (26.12). Aníbal decide então marchar a Roma, mas uma tempestade e outros acontecimentos fazem com que Aníbal retire-se de lá.

Nos capítulos 37 e 38 do livro 26, Lívio avalia o momento da guerra como incerto tanto para romanos quanto para cartagineses, que tinham ambos conquistas e perdas de território, e derrotas e vitórias. A Fortuna parecia contrabalancear os resultados. Mas segundo o historiador, Aníbal parece não se comportar bem nesta situação e isto afastava aliados (26.38.1-5):

Hannibalem ante omnia angebat quod Capua pertinacius oppugnata ab Romanis quam defensa $a b$ se multorum Italiae populorum animos averterat, quos neque omnis tenere praesidiis, nisi vellet in multas parvasque partis carpere exercitum, quod minime tum expediebat, poterat, nec deductis praesidiis spei liberam vel obnoxiam timori sociorum relinquere fidem. Praeceps in avaritiam et crudelitatem animus ad spolianda quae tueri nequibat, ut vastata hosti relinquerentur, inclinavit. Id foedum consilium cum incepto, tum etiam exitu fuit. Neque enim indigna patientium modo abalienabantur animi, sed ceterorum etiam; quippe ad pluris exemplum quam perpessio malorum pertinebat. $\mathrm{Nec}$ consul Romanus temptandis urbibus, sicunde spes aliqua se ostendisset, deerat. (Liv. 26.38.1-5).

Diante de tudo, atormentava Aníbal o fato de que Cápua, atacada mais obstinadamente pelos romanos do que podia defendê-la, convertera os ânimos de muitos povos itálicos, que Aníbal não podia conter com suas defesas, a não ser que separasse o exército em várias partes pequenas, o que pouco resolvia neste caso. Tampouco Aníbal podia remover as guarnições e deixar a lealdade dos aliados livre às expectativas ou dependente do medo. Seu caráter inclinado à avareza e crueldade levou-o a espoliar as cidades que não podia proteger, para que ficassem devastadas para o inimigo. Essa decisão foi horrível tanto no seu planejamento quanto também na sua execução. Pois desse modo repelia os ânimos não apenas dos que sofriam tais injustiças, mas também de outros, pois o exemplo, mais do que o sofrimento, alcançava a muitos. E o cônsul romano não entregara as cidades ao abandono quando alguma esperança foi mostrada. 
O comportamento agressivo de Aníbal diante dos aliados o prejudica em solo itálico, pois impede que consiga novas parcerias. E esse erro é visto pelo autor como decorrente de seu caráter.

$\mathrm{Na}$ batalha travada na conspiração em Salápia, o historiador ressalta que Aníbal perdera importante esquadrão de cavaleiros, de maneira que sua cavalaria, seu grande trunfo, não seria mais a mesma (26.38). Cipião Africano, já em alta, descreve Aníbal como já derrotado e sua empresa como fracassada em seguida. Ele afirma que o valor romano subsistiu em meio a tantas derrotas e perdas, e que os deuses não estão mais favoráveis a Aníbal: "Aníbal, depois de ter percorrido um longo território após ter fugido de Roma, impelido para o canto mais distante do Brúcio, só pede aos deuses que o deixe sair são e salvo do território inimigo" (26.41.16).

No livro 27, Lívio relata a retomada de Tarento pelos romanos, sob o comando de Fábio (27.16), enquanto Aníbal combatia contra Marcelo em Canúsia. Marcelo é morto em uma emboscada tramada por Aníbal (27.27). Em seguida, o cartaginês é derrotado por Quinto Claúdio em Grumento, na Lucânia (27.42). O final do livro 27 narra a derrota do exército de Asdrúbal, irmão de Aníbal, que acabara de chegar a Itália (derrota que Lívio iguala a Canas). $\mathrm{Na}$ ocasião, a união de alguns exército romanos, e a engenhosidade vencem os cartagineses e matam Asdrúbal. A cabeça do general é enviada a Aníbal, que, em seguida, retira-se para Brúcio. No livro 28, centrado nas ações de Cipião, Aníbal nada empreende. No livro 29, no qual Cipião chega à África, Aníbal ainda combate em Crotona e é derrotado (29.36). Já no livro 30, Lívio descreve seu retorno à África, contra sua vontade, e a derrota final para Cipião na batalha de Zama.

Como vemos, a partir do livro 23, Aníbal alterna vitórias e derrotas, e outro general, vive uma trajetória ascendente: Cipião Africano. O caráter e ações de Cipião parecerão ser, em alguns momentos, construídos por semelhança e contraste com Aníbal. Vimos que nos dois primeiros livros, a precipitação dos generais romanos contrastava com a prudência e inteligência de Aníbal. Depois, muitas vezes Aníbal será vencido justamente por estratégias dos romanos, ou suas artimanhas falharão em alguns momentos. Na narrativa da retomada de Cápua pelos romanos, uma artimanha de Aníbal é facilmente descoberta (26.6). Na tentativa de se aproximar de Salápia, Aníbal prepara um estratagema, mas é descoberto pelo inimigo, que transforma a armação numa emboscada para ele mesmo (suamet ipse fraude captus, 27.28.13). É como se suas estratégias não surtissem mais o mesmo efeito. A cidade de Tarento, tomada com estratégia por Aníbal (25.10-11), é, segundo a narrativa, retomada por Fábio com a mesma artimanha utilizada pelo cartaginês. Aníbal, quando sabe da notícia, 
exclama: "Et Romani suum Hannibalem" inquit "habent; eadem qua caperamus arte tarentum amisimus". "E os romanos agora tem seu próprio Aníbal”, diz, "pela mesma artimanha capturamos e perdemos Tarento" (27.16.10). Logo em seguida, a narrativa ressalta que Fábio não caiu na emboscada de Aníbal junto aos metapontinos. Entretanto, ainda no livro 27, Marcelo é morto em uma emboscada de Aníbal (27.26.1-2), demonstrando que Aníbal não está completamente superado. Embora nem todas as suas estratégias se tornem ineficientes, parece claro que na narrativa elas são superadas aos poucos pela estratégia e inteligência romana, até que Cipião Africano supere Aníbal totalmente.

Já no livro 26, na narrativa das ações romanas na Espanha, Cipião, jovem como Aníbal no início da guerra, é descrito agindo com inteligência. Ele toma com estratégia a cidade de Nova Cartago (26.45-49), e é generoso com os hispânicos. A atitude bondosa de Cipião contrasta com a pilhagem que Aníbal faz de seus aliados itálicos, e estrategicamente atrai aliados. A batalha final de Cipião na Espanha demonstra bem como o historiador constrói o general como um estrategista. Em 28.33, Lívio relata que Cipião atraiu, expondo um rebanho formado por animais capturados ao longo do caminho, a cavalaria dos espanhóis para uma emboscada em um vale. Em seguida dispõe seu exército de maneira que dividiu os espanhóis em dois grupos, e assim Cipião massacrou os espanhóis. As estratégias de Cipião nos lembram as de Aníbal no início da década. Mas a comparação é ainda mais explícita em outros trechos.

Lívio faz Cipião discursar no livro 28, quando tenta convencer o Senado de que a guerra deveria ser levada à África, e o comandante cita Aníbal como o grande exemplum de quem levou a guerra até o território do inimigo.

"Si hercules nihilo maturius hoc quo ego censeo modo perficeretur bellum, tamen ad dignitatem populi Romani famamque apud reges gentesque externas pertinebat, non ad defendendam modo Italiam, sed ad inferenda etiam Africae arma videri nobis animum esse, nec hoc credi volgarique, quod Hannibal ausus sit neminem ducem Romanum audere, et priore Punico bello tum cum de Sicilia certaretur, totiens Africam ab nostris exercitibusque et classibus oppugnatam, nunc, cum de Italia certetur, Africam pacatam esse" (Liv. 28.44.12-13).

"Se, por Hércules, o fim da guerra não for adiantado com meu plano, ao menos se propaga a dignidade e fama do povo romano entre os reis e povos estrangeiros. Que vejam que temos disposição não apenas para defender a Itália, mas para levar as armas até a África. Que não se creia e divulgue que o quê Aníbal ousou nenhum comandante romano ousa! Na guerra anterior, quando se lutava pela Sicília, tantas vezes nossos exércitos e frotas atacarem a África; e, agora, quando é pela Itália que se luta, a África está tranquila!". 
Cipião incita Roma a utilizar a mesma estratégia do cartaginês, e a sua vitória mostrará que ele soube aproveitar o exemplo de Aníbal. Pelo discurso fica claro que era preciso superar a audácia de Aníbal. No discurso de Aníbal a Cipião, antes da batalha de Zama, o próprio cartaginês parece considerar Cipião seu êmulo. Aníbal pede uma entrevista com Cipião visando um acordo, sendo que Lívio diz não saber se ele fez isso por iniciativa própria ou vontade pública. No discurso, ficcionado em 30.30, Aníbal tenta convencer Cipião de que a guerra é fruto da cobiça de terras alheias, de que é melhor preferir a razão a tal cobiça, e adverte que a fortuna é mutável, sendo que ele mesmo era o melhor exemplo da mutabilidade da sorte. Aníbal então tenta equiparar Cipião a ele mesmo, na tentativa de dissuadi-lo da guerra, já que a Fortuna, favorável aos romanos nos últimos momentos, poderia mudar, como mudou com ele. Importa-nos, entretanto, a maneira como Lívio, através do discurso do cartaginês, destaca e cria semelhanças entre os dois generais:

Quod ego fui ad Trasumennum, ad Cannas, id tu hodie es. Vixdum militari aetate imperio accepto omnia audacissime incipientem nusquam fefellit fortuna. Patris et patrui persecutus mortem ex calamitate vestrae domus decus insigne uirtutis pietatisque eximiae cepisti; amissas Hispanias reciperasti quattuor inde Punicis exercitibus pulsis; consul creatus, cum ceteris ad tutandam Italiam parum animi esset, transgressus in Africam duobus hic exercitibus caesis, binis eadem hora captis simul incensisque castris, Syphace potentissimo rege capto, tot urbibus regni eius, tot nostri imperii ereptis, me sextum decimum iam annum haerentem in possessione Italiae detraxisti. Potest victoriam malle quam pacem animus. Novi spiritus magnos magis quam utiles; et mihi talis aliquando fortuna adfulsit. (Liv. 30.12-15). ${ }^{224}$

Aquilo que fui em Trasimeno e em Cannas, hoje tu és. Tendo tomado audaciosamente o comando de todas as coisas ainda antes da idade militar, a fortuna em nada o fez inexperiente. Perseguiste a morte do pai e do tio desde a destruição de sua casa e alcançaste fama distinta de virtuoso de grande piedade. Recuperaste as províncias da Hispânia após derrotar quatro vezes os exércitos púnicos. Foste eleito cônsul, e quando havia poucas alternativas para guardar a Itália, vieste para África, derrotando dois exércitos, capturados os dois no mesmo instante em que os acampamentos foram incendiados. Aprisionaste Sífax, o mais poderoso rei, e com tantos de seus reinos e cidades e tantos de nossos impérios tomados, obrigou-me a regressar de minha empresa de ocupação da Itália que durava já dezesseis anos. O espírito pode preferir a vitória à paz. Sei que tais aspirações são mais nobres do que úteis, e para mim mesmo a fortuna já se inclinou desta maneira.

Ambos iniciam a carreira na juventude, e tem a oportunidade de vingar a morte de seus antepassados. Ambos obtém grandes vitórias, e vão até a casa do inimigo. Andreola Rossi afirma que o trecho convida o leitor a reler e interpretar as histórias dos dois generais como vidas paralelas ${ }^{225}$. A autora traça paralelos e correspondências entre eventos de Aníbal

\footnotetext{
${ }^{224}$ A advertência de Aníbal a Cipião parece apresentar algumas semelhanças com o discurso de Creso a Ciro narrado por Heródoto em 1.207.1-3.

${ }^{225}$ Rossi (2004, 360).
} 
na primeira metade da terceira década e de Cipião na segunda. Para Rossi, a construção paralela, as situações correspondentes vividas pelos dois, evidenciam as diferenças entre os dois e a inferioridade de Aníbal. Rossi analisa eventos parecidos das trajetórias do dois em que há, na sua visão, diferentes comportamentos. Por exemplo, segundo a estudiosa, ambos discursam e debatem a favor de levar à guerra ao outro país, mas Aníbal o faz mais por motivações próprias do que pela pátria (fato, entretanto, que não é confirmado pela narrativa de Lívio), Aníbal deixa seu exército corromper-se em Cápua e Cipião não deixa que isso aconteça no inverno em Siracusa (29.22). Entretanto, é preciso tomar cuidado com as conclusões generalizantes da autora, pois o estudo parece partir da visão limitada de E. Burck $^{226}$, de que Aníbal é construído na Terceira Década como um caráter de apenas vícios, simbolizando os vícios dos estrangeiros, que contrastariam então com as virtudes romanas, presentes na figura de Cipião. Aníbal vicioso representaria a futura decadência moral romana, assim como o próprio Cipião após a Terceira Década também viverá certa ambiguidade moral. Rossi parece errar ao ver Aníbal e Cipião somente como antíteses, pois como veremos, o texto aponta também para semelhanças entre os dois. Além disso, como já dissemos, a obra não é simplista em opor estrangeiro e romano.

Ao construir Cipião como êmulo, Lívio não nos parece demonstrar as diferenças, mas sim as semelhanças, de maneira que as virtudes do Aníbal vitorioso deveriam sim ser imitadas e superadas. Fica claro pela narrativa que a inteligencia estratégica é a principal qualidade de Aníbal a ser imitada e superada. É evidente, entretanto, que alguns vícios de Aníbal contrastarão com os de romanos virtuosos, no entanto, não somente com o de Cipião. Segundo Levene, quando Lívio representa um cartaginês mais como romano do que um bárbaro, ele o faz em um contexto da guerra em que a vitória pertence a Roma, mas apenas por um preço alto. Em outras palavras, Lívio retrata Cartago como um inimigo grandioso, para que a vitória seja honrosa, e as derrotas sofridas pouco ridículas. Assim, a leitura de Rossi nos leva à partição simples entre romano e estrangeiro, enquanto, mais adequadamente à visão do historiador, Cartago não é bárbara, ela é uma quase-Roma, sua eterna rival ${ }^{227}$, como na Eneida de Virgílio e como seria depois em Punica de Sílio Itálico.

Considerando que a qualidade estratégica de Aníbal é emulada por Roma, devemos nos perguntar, entretanto, de que tipo de estratagemas estamos falando. No retrato de sua juventude Aníbal é vituperado por possuir o vício da perfídia cartaginesa. Diante disso,

\footnotetext{
${ }^{226}$ E. Burck, The Third Decade. In: Dorey (1971).

${ }^{227}$ Cf. Levene $(2010,236)$.
} 
estratégia e perfídia são distintas na visão do historiador? Em outras palavras, seriam as estratégias de Aníbal criminosas e fraudulentas? Segundo Levene, os romanos tinham uma reação ambivalente diante do uso da estratégia na guerra em vez do combate simples das frentes. Há contextos em que o uso a estratégia é considerado moralmente inferior, e há contextos em que a deliberação e sabedoria na guerra são superiores do que o mero uso da força. Para o estudioso, Lívio tende a tratar a oposição em termos de "coragem tradicional romana" versus "engano criminoso", sem que isso o impeça de criticar comandantes sem inteligência e louvar estratégias alternativas como a de Fábio Máximo ${ }^{228}$. Parece-nos que Lívio no decorrer da narrativa propõe uma discussão dessa antítese, tendendo a considerar as estratégias de Aníbal nas batalhas (e também dos Fábios e de Cipião) como louvável. A reflexão e discussão do tema fica bastante clara no livro 22 quando o método paralelo de Fábio é criticado por Minúcio e discutido no Senado. Quinto Fábio, na ocasião, já havia sido comparado a Aníbal, por causa de sua estratégia (22.12.5). Lívio parece ver a estratégia de Fábio como positiva, pois a personagem que a critica, Minúcio, é derrotada facilmente. Em 25.39.1, Lívio ressalta que a vitória de Márcio na Hispânia se deu por um método fenício, arte punica, sem qualificar como ruim. A inteligência de Cipião, como vimos, é um elemento destacado por Lívio nas descrições de suas ações, e parece também justiçar a vitória romana.

Levene defende que Lívio, no início do livro 30, descreve Cipião executando vários estratagemas que quase beiram à perfídia nos primeiros confrontos em solo africano ${ }^{229}$. Na narrativa dos acontecimentos da batalha de Zama, o historiador enfatiza a estratégia de Cipião. Embora elogie o posicionamento que Aníbal fez dos elefantes e de seus homens, a derrota cartaginesa explica-se pelo combate armado por Cipião, que logo no início faz com que os elefantes voltem-se para a linha cartaginesa com o uso de trombetas, causando confusão na cavalaria do lado dos cartagineses. Além disso, Cipião deixa corredores para que os elefantes passem sem massacrar seus homens. Com a formação cartaginesa já desestabilizada, e devido à multiplicidade dos homens que lutavam do lado cartaginês, a unidade romana, sua formação fechada, prevaleceu (30.32-34). Assim, não nos parece que Lívio considere criminosas as ações estratégicas nas batalhas tanto vencidas por Aníbal quanto por Cipião. Pelo contrário, a narrativa parece ser construída de maneira a mostrar que a única maneira de vencer Aníbal é superando-o em estratégia. Tal ideia, entretanto, como se dá com muitas outras questões, está apenas sugerida na narrativa, por vozes das personagens e pelas ações descritas.

\footnotetext{
${ }^{228}$ Levene $(2010,229)$.

${ }^{229}$ Cf. Levene $(2010,233)$.
} 


\subsection{O louvor do inimigo}

Embora a narrativa já retratasse Aníbal como enfraquecido no fim da guerra, é preciso recordar seu valor para que a vitória romana seja gloriosa, pois, como sabemos, para Lívio, de uma maneira geral, o passado romano é virtuoso. Para engrandecer o Aníbal que seria vencido por Cipião, o historiador recorda seu valor, através do discurso dos soldados romanos, temerosos na iminência da batalha em Zama. O discurso é indireto livre, e não é possível saber exatamente se trata-se da voz dos soldados, de Fábio ou das recordações de Fábio ou reflexões do próprio narrador:

Nec Scipioni aut cum Syphace, inconditae barbariae rege, cui Statorius semilixa ducere exercitus solitus sit, aut cum socero eius Hasdrubale, fugacissimo duce, rem futuram, aut cum tumultuariis exercitibus ex agrestium semermi turba subito conlectis, sed cum Hannibale, prope nato in praetorio patris, fortissimi ducis, alito atque educato inter arma, puero quondam milite, vixdum iuvene imperatore, qui senex vincendo factus Hispanias, Gallias, Italiam ab Alpibus ad fretum monumentis ingentium rerum complesset. Ducere exercitum aequalem stipendiis suis, duratum omnium rerum patientia quas vix fides fiat homines passos, perfusum miliens cruore Romano, exuvias non militum tantum, sed etiam imperatorum portantem. Multos occursuros Scipioni in acie qui praetores, qui imperatores, qui consules Romanos sua manu occidissent, muralibus vallaribusque insignes coronis, pervagatos capta castra, captas urbes Romanas. Non esse hodie tot fasces magistratibus populi Romani, quot captos ex caede imperatorum prae se ferre posset Hannibal (Liv. 30.28. 3-7).

E Cipião não iria ao encontro de Sífax, rei de bárbaros desordenados, exército dirigido por Estatório, um empregado, ou de Asdrúbal, general rapidíssimo na fuga, ou de exércitos tumultuados, formados às pressas por uma multidão meio armada de camponeses, mas de Aníbal, o mais forte dos generais, praticamente nascido no acampamento militar do pai, criado e educado entre as armas, soldado desde menino, comandante ainda na juventude, que envelheceu em vitórias, e encheu a Hispânia, a Gália e a Itália dos Alpes até o Estreito com monumentos de seus feitos grandiosos. Aníbal dirigia um exército com tantos anos de serviço quanto ele, exército fortalecido por toda sorte de sofrimentos que dificilmente acreditar-se-ia que homens enfrentaram, banhado pelo sangue romano inúmeras vezes, portador de despojos não apenas de grandes soldados, mas também de generais. Cipão enfrentaria na batalha muitos que mataram com suas próprias mãos pretores, generais e cônsules romanos, recompensados com coroas por terem atravessados primeiro muralhas e trincheiras, que percorreram acampamentos e cidades romanas capturadas. Os magistrados do povo não possuíam hoje tantas insígnias quanto as que Aníbal deveria carregar consigo, apanhadas na morte dos cônsules.

A imagem de Aníbal como grande general deve ser permanecer na memória do leitor para que Roma seja exaltada com a glória de ter vencido um grande inimigo. Essa mesma imagem prevalecerá na obra após a Terceira Década. Aníbal aparecerá algumas vezes em cena, agindo, e em outros momentos é citado em reflexões do historiador. O foco da narrativa, 
na Quarta Década é, entre outros assuntos, os feitos da guerra entre Síria e Roma, dos quais Aníbal só participa em segundo plano.

Terminada a Segunda Guerra Púnica, feito o acordo de paz, Aníbal permanece por um tempo em Cartago, e exerce inclusive uma magistratura (33.46). Entretanto, ele foge ao saber da vinda de alguns embaixadores romanos, pois achava que seria para capturá-lo (33.48). Realmente, o partido da oposição havia dito ao Senado que Aníbal trocara cartas com Antíoco, rei da Síria, que estava prestes a guerrear contra Roma. Além disso, Lívio relata que diziam que o ódio de Aníbal continuava implacável, e que ele vivia reclamando de que a cidade estava muito inativa, e só o som das armas a faria despertar (30.45.6). De fato, Lívio narra que Aníbal junta-se a Antíoco, e o estimula a levar a guerra até Roma: “Aníbal só acalentava um único e constante desejo: fazer a guerra na Itália (34.60)”. Assim, Aníbal após a Terceira Década é retratado como um guerreiro obstinado, que não desistira de cumprir o juramento feito quando criança. Aliás, em 35.19.2, Aníbal, apartado do conselho de Antíoco por causa da suspeita que recaíra sobre ele, relata tal juramento ao rei, relembrando assim o leitor de sua fidelidade e palavra, de eterno ódio aos romanos. O episódio é lembrado não apenas para confirmar sua fides, mas para incentivar a guerra. O historiador o caracteriza duas vezes como sábio e gênio da guerra no livro 36. Em 36.15.2, Aníbal é admirado por Antíoco:

“[...] Hannibalem vero non ut prudentem tantum virum sed prope vatem omnium, quae tum evenirent, admirari".

“[...] admirava Aníbal por ser não apenas homem sábio, mas quase um adivinho de tudo que acontecera.

E novamente em 36.41.6, quando o historiador diz que Aníbal era o único a prever que Roma viria até a Ásia guerrear contra Antíoco.

Quando a Síria perde a guerra, Aníbal é exigido como refém no acordo de paz entre Cipião e Antíoco, e é caracterizado como um inimigo ainda nocivo:

[...] sed nunquam satis liquebit nobis ibi pacem esse populo Romano, onde Hannibal erit; eum ante omnia deposcimus (Liv. 37.45.16).

"Jamais veremos o povo romano verdadeiramente em paz onde quer que se encontre Aníbal; é ele que reclamamos antes de tudo".

Aníbal é citado novamente no livro 39, quando o historiador relata sua morte, o que é feito em um contexto em que o historiador exalta o valor de três grandes generais (Cipião, Aníbal e Filopêmen); trata-se também de um momento de crítica aos líderes do tempo das ações descritas pela narrativa. O discurso de Aníbal no instante de sua morte, a maneira como 
foi encurralado, sem honra nenhuma para o embaixador romano que capturaria facilmente um velho desarmado, são na opinião da personagem, uma ilustração de como "mudaram os costumes romanos".

Hannibal, postquam est nuntiatum milites regios in vestibulo esse, postico, quod devium maxime atque occultissimi exitus erat, fugere conatus, ut id quoque occursu militum obsaeptum sensit et omnia circa clausa custodiis dispositis esse venenum, quod multo ante praeparatum ad tales habebat casus, poposcit. "Liberemus" inquit "diuturna cura populum Romanum, quando mortem senis exspectare longum censent. Nec magnam nec memorabilem ex inermi proditoque Flamininus victoriam feret. Mores quidem populi Romani quantum mutaverint, vel hic dies argumento erit. Horum patres Pyrrho regi, hosti armato, exercitum in Italia habenti, ut a veneno caueret praedixerunt: hi legatum consularem, qui auctor esset Prusiae per scelus occidendi hospitis, miserunt." Execratus deinde in caput regnumque Prusiae et hospitales deos violatae ab eo fidei testes invocans, poculum exhausit. Hic vitae exitus fuit Hannibalis. (Liv. 39.51.7-12).

Aníbal, quando the foi anunciado que os soldados do rei estavam no vestíbulo, tentou fugir pelos fundos, pela passagem mais oculta e retirada, e quando percebeu que também essa estava obstruída por militares e tudo cercado por fileiras de guardas, pediu que trouxessem o veneno que havia sido preparado muito antes pra ocasiões como essa. "Livremos", diz, "o povo romano de sua longa preocupação, já que não podem aguardar pacientemente a morte de um velho. Nem grandiosa nem memorável será a vitória de Flamínio sobre um inimigo desarmado e traído. Este dia ilustra quanto mudaram certos costumes do povo romano. Os pais desses avisaram ao rei Pirro, inimigo armado que estava com exército na Itália, de que se precavesse contra envenenamento; esses, enviaram um embaixador consular para que Prúsias se tornasse o autor do crime de matar seu hóspede". E então, tendo amaldiçoado a cabeça e o reino de Prúsias, e invocando os deuses da hospitabilidade a que fossem testemunhas da violação da fidelidade, bebeu da taça.

Lívio parece expor através da opinião de Aníbal vícios de romanos daquela tempo da narrativa. A fidelidade de Aníbal e a sabedoria evidenciada através de seu discurso compõem uma narrativa laudatória do encerramento da vida do general, e cria um contraste com a ação romana pouco gloriosa. Lívio mais uma vez discute a oposição simplista de romano virtuoso e estrangeiro viciosa.

Em tom de epitáfio, no capítulo seguinte, Lívio discorda de outros historiadores a respeito de que a morte de Cipião e Aníbal se deram no mesmo ano, mas reúne os três (Cipião, Filopêmen e Aníbal) pelo fato de nenhum deles ter encontrado um fim adequado ao brilho de suas existências: "nemo eorum satis dignum splendore vitae exitum habuit" (39.52). Neste trecho, é interessante que Aníbal e Cipião são colocados lado a lado novamente. A imagem de Aníbal última exposta pelo historiador é a de um general brilhante, e, apesar de estrangeiro, mais virtuoso do que os líderes romanos daquele momento, que foram capturá-lo sem glória nenhuma. 
A imagem na quarta década é a de um gênio da guerra, e grande inimigo de Roma. No livro 30, momento em que Aníbal seria vencido definitivamente, convém exaltá-lo, para engrandecer o vitorioso. E na década seguinte esta imagem é perpetuada, talvez fosse esta a imagem de Aníbal que convém ficar na memória. Sua caracterização como grande estrategista no início da terceira década também coopera para essa ideia. Mas como vimos, seu êthos foi construído ambiguamente, tanto pela voz do historiador quanto pelo jogo de vozes das personagens e de outras fontes do autor. Como vimos, os vícios e ações mais graves são relativizados pelo narrador através do discurso de outras personagens. O historiador assim sugere causas para os acontecimentos da derrota cartaginesa, e deixa para o leitor decidir sobre qual imagem é mais verossímil. Como já havíamos dito, a verossimilhança é para Tito Lívio a medida do verdadeiro. Seu êthos é complexo, apesar de em muitos momentos ser construídos através de estereótipos. Várias imagens são sobrepostas, e é difícil saber qual à a real opinião do historiador. O caráter construído parece voluntariamente construído ambiguamente, e isso serve para dois aspectos essenciais da obra: reconstruir a história em termos de causalidade moral, o que em certo grau contribui também para uma possível função didática da obra, e exaltar Roma, que superou um inimigo grandioso. 


\section{O GÊNERO BIOGRÁFICO E A VIDA DE $A N I ́ B A L$}

\subsection{Os limites do gênero biográfico}

"Political philosophy may be learned from history, and ethical from biography". Casaubon ${ }^{230}$.

O termo biografia aparece pela primeira vez nos fragmentos de vida de Isidoro, de Damáscio (séc 5 d.C.), preservados na Bibliotheca de Fócio, já do século nono. A biografia antiga era designada por alguns autores (já que muitos materiais ou antecedentes biográficos não foram designados como tais pelos autores), pelo termo grego bios ${ }^{231}$, e em latim vita ${ }^{232}$. Como veremos, há muita dificuldade de reconstruir a história do gênero das Vidas, investigar seu surgimento, uma vez que a maioria das obras que sabemos ter existido por testemunho de autores antigos está perdida.

O livro de Arnaldo Momigliano, The Development of Greek Biography, publicado pela primeira vez em 1971, é indispensável para o estudo da biografia antiga, por analisar profundamente o possível surgimento da biografia grega. A partir da leitura dessa obra traçaremos uma história do gênero, e apresentaremos alguns pontos problematizados por críticos posteriores. Nessa obra o historiador busca analisar informações e fragmentos de autores desde o século quinto a. C., que, por apresentarem interesse biográfico, podem ter sido antecedentes do gênero; suas obras podem ter sido o material biográfico que influenciaria ou serviria de modelos pra futuros biógrafos.

Momigliano começa contrastando a escassez de exemplares dos escritos biográficos com os da historiografia política, gênero do qual nos restou muitas obras. Para aspectos da literatura biográfica no século IV temos que nos fiar no Evágoras de Isócrates e Agesilau de Xenofonte, que se dizem escritores de encomia, e a Ciropedia de Xenofonte, uma novela filosófica. Do século terceiro, restou apenas um fragmento da Vida de Eurípedes, de Sátiro. A primeira coleção de biografias que chegou até nós é justamente parte da obra de Cornélio Nepos, já do século I a.C. Através de sumários, compilações e scholia, sabemos que houve uma atividade dos eruditos helenistas em elaborar biografias de poetas, oradores e filósofos ${ }^{233}$.

\footnotetext{
${ }^{230}$ I. Casaubon, no Prefácio de sua edição da Historia Augusta (1603), apud Magie, p.xxix, The Scriptores Historiae Augustae, vol.1, Cambridge, London: Harvad; Heinemann, 1979.

${ }^{231}$ Cf. Plu. Thes.1; Ph.2.180

${ }^{232}$ Cf. Nep. Ep. 4.6; Tac., Ann, 16.28; Sue. Cl. 41.3.

${ }^{233}$ Momigliano $(1993,9)$.
} 
Estão perdidas também as monografias sobre reis comuns no período helenístico, incluindo as histórias de Alexandre, que nos permitiriam traçar um paralelo entre biografia política e historiografia, e outros trabalhos, como de Hermipo de Esmirna. É somente no período imperial que biografia florescerá, e posteriormente mais ainda com as biografias cristãs, já no período após Constantino.

Sobre autores modernos que analisaram o surgimento da biografia, Momigliano cita e refuta algumas ideias de alguns. Friedrich Leo, em 1901, Die griechisch-römische Biographie nach ihrer literarischen Form, tentou definir as formas da biografia no período helenístico. Leo partiu de Plutarco e Suetônio e teorizou que eles representavam dois tipos diferentes de biografia. O tipo suetoniâno seria caracterizado por uma combinação de um relato em ordem cronológica com uma sistemática caracterização do indivíduo e de seus feitos; e sua origem remontaria aos gramáticos alexandrinos. O tipo plutarquiano caracterizar-se-ia por um rígido relato cronológico de eventos, e por isso mais adequado à biografias de generais e políticos, enquanto o tipo suetoniâno seria mais adequando à vidas de intelectuais. A origem do tipo plutarquiano poderia ser encontrada nos Peripatéticos. Mas, segundo Momigliano, essa tese foi depois criticada por Weizsäker, que, já em 1931, percebeu que a rigidez cronológica em Plutarco não ocorria o tempo todo. Mas Momigliano ressalta que permanece verdadeira a demonstração de Leo de que Suetônio esteve sob a influência de uma abordagem antiquária da biografia, enquanto Plutarco estava mais perto da historiografia política. Como veremos, Momigliano contesta a teoria de Leo sobre a origem do gênero biográfico ao demonstrar que obras biográficas provavelmente já existiam no século quinto, antes da escola peripatética.

Depois, Dihle, Studien zur griechischen Biographie (1956), tentou traçar as origens da biografia grega através de Sócrates e dos Socráticos. Ele defendeu que uma grande personalidade deveria ter motivado o nascimento da biografia, e que esta pessoa seria Sócrates. Entretanto, evidências demonstram que a bios já existia um século antes da morte de Sócrates $^{234}$. Bruns, em 1896, Das literarische Porträt der Griechenim fünften und vierten Jahrhundert vor Christi Geburt, vê uma oposição entre caracterização indireta das personagens nos historiadores (Tucídides e Políbio), e caracterização direta em escritos biográficos (Anabasis de Xenofonte) ${ }^{235}$. Mas Bruns não discutiu a origem da biografia e nem da autobiografia. Misch, em Geschichte der Autoiographie (1976), não analisou exclusivamente escritos autobiográficos como um gênero, mas analisou trechos de prosa e poesia que continham elementos biográficos. Para Momigliano, o trabalho é interessante no

\footnotetext{
$\overline{{ }^{234} \text { Cf. Momigliano }(1993,17) \text {. }}$

235 Momigliano $(1993,16)$.
} 
que diz respeito àquilo que os antigos pensavam sobre si mesmos, mas é confuso no que diz respeito a uma história do gênero autobiográfico.

Momigliano, como já dissemos, a partir de sua própria investigação, debruça-se primeiramente sobre o século quinto grego, buscando antecedentes da biografia e da autobiografia em secções de trabalhos que tem o propósito explícito do relato de um indivíduo isoladamente, como em anedotas, coleção de ditos, coleções de cartas, e discursos apologéticos. O historiador destaca como relevantes para o surgimento da biografia o interesse dos gregos por heróis do passado, encontrado em poemas que contavam episódios de suas vidas, e também a curiosidade acerca de personalidades dos poetas antigos, como Homero e Hesíodo. Especulações sobre suas vidas foram objetos de historiadores e sofistas. Outro objeto que parece ter interessado os leitores do século quinto foram o Sete Sábios; uma obra Banquete dos Sete Homens Sábios teria circulado no século quinto, assim como histórias populares sobre a vida de Esopo $^{236}$. Entretanto, podemos afirmar que tais obras são contribuições; a existência de biografias propriamente ditas no século quinto é conjectural, mas Momigliano considera provável. Esta talvez seja a origem da biografia literária, vidas de sábios e de poetas. A biografia política, vidas de reis, líderes e generais, pode ter encontrado antecedentes meio século antes, na Jônia, nos relatos autobiográficos de viagem.

Escílax de Carianda escreveu sobre Heraclides de Milasa provavelmente próximos aos 480 a.C., e teria escrito também uma obra com características autobiográficas, ao descrever em prosa uma viagem real. Íon de Quios também escreveu um relato de viagens, ou visitas (o título é $\left.{ }^{\mathrm{E}} \pi \mathrm{\imath} \delta \eta \mu \mathbf{i}_{\alpha}\right)$, perto de 440 a.C.. Para Cerri \& Gentili, os retratos criados por Íon em Epidemiai lembram a técnica do retrato pintado mais que a da narrativa biográfica real. Eles continham um elemento da biografia posterior, ao centrar no comportamento diário mais que nos grandes eventos históricos, em uma rotina diária significante na qual o êthos do herói é $\operatorname{mostrado}^{237}$.

Momigliano aponta ainda obras do século quinto como de Estesimbroto de Tasos, de quem temos fragmentos de um panfleto sobre Temístocles, Tucídides, filho de Melesias e Péricles. Tal autor teria se interessado mais por peculiaridades dos líderes políticos do que por atacar suas políticas. Seria também um antecedente da biografia político o excurso de Teopompo, contido em Philippica, sobre os demagogos atenienses. Ainda, através da informação de Diógenes de Laércio em sua vida de Empédocles (8.63), sabemos que Xanto fez um relato sobre Empédocles. Momigliano acredita que se trata de Xanto da Lídia, mas não

\footnotetext{
${ }^{236}$ Cf. Momigliano (1993, 21-8)

${ }^{237}$ Cerri \& Gentili $(1988,72)$.
} 
podemos ainda afirmar que tal relato constitui uma biografia, embora entre os antecedentes já citados, as obras de Xanto e Escílax são as mais prováveis de terem sido talvez biografias propriamente. Momigliano conclui destas evidências que trabalhos biográficos ou autobiográficos eram conhecidos no século quinto, e que muitas destas obras referidas poderiam se enquadrar na sua definição de biografia como um relato de uma vida desde o nascimento até a morte.

Outro ponto relevante observado por Momigliano é a influência persa no surgimento da biografia. Lendo Heródoto e Tucídides, percebe-se que o interesse em detalhes biográficos de figuras políticas era mais vivo na Ásia Menor e na cultura jônica que nos centros gregos no quinto século. A autobiografia era um gênero literário cultivado em vários países do Império Persa do Egito à Assíria. Neemias e talvez Esdras tenham escrito autobiografias na Judeia no século quinto. Escílax e Xanto teriam escritos seus trabalhos neste mesmo momento, talvez debaixo de uma mesma influência persa, já que os conteúdos de ambos são persas.

Momigliano observa ainda que nem as tragédias e nem a arte plástica do século quinto apresentam habilidades em técnicas biográficas, o que era é mais aparente na Comédia e a Historiografia. Segundo ele, há abundante material biográfico nas comédias de Aristófanes. A Historiografia política grega enfatizava mais o estado como protagonista do que os indivíduos; os espartanos e atenienses, e não Leônidas nem Temístocles são os protagonistas da Guerra do Peloponeso. O valor do indivíduo estava em sua contribuição para o estado. A historía, neste momento, não apresenta um indivíduo como protagonista; seu o foco é o conjunto.

Segundo o historiador, no século quarto há um grande aumento de evidências de interesse pela biografia e autobiografia. Os monumentos funerários confirmam este maior interesse pela intimidade pessoal, e os epigramas fúnebres deste século apresentam mais detalhes biográficos. No quarto século temos também nova situação política, os estados, em sua maioria, passam a ser guiados por líderes individuais, como Lisandro, Agesilau, Dionísio, o Velho, e Alexandre, o Grande. Além disso, as novas tendências filosóficas e retóricas enfatizam a importância da educação para o indivíduo, e valorizam a performance e o autocontrole.

Os Socráticos no século quarto foram líderes de experimentos direcionados a capturar potencialidades mais do que realidades das vidas dos indivíduos. Para Momigliano, a biografia no quarto século veio para ocupar uma posição ambígua entre fato e imaginação. Platão e Xenofonte aparentemente criaram novos tipos de narrativa biográficas e autobiográficas. Isócrates com seus ensinamentos retóricos teve grande contribuição para a 
técnica dos relatos biográficos. Ele também escreveu, em cerca de 370 a.C., Evágoras, um encômio em prosa, organizado em ordem cronológica, mas que não pode ser considerado propriamente uma biografia de Evágoras de seu nascimento até sua morte. Isócrates afirma ser o primeiro a louvar as virtudes de um homem em prosa. Entretanto, discursos fúnebres laudatórios já eram comuns. Osley ${ }^{238}$ afirma que Isócrates com tal afirmação quis dizer que era o primeiro a combinar um relato das ações de um homem com o louvor do seu caráter, mostrando a importância das ações e ao mesmo tempo as virtudes do herói.

Tal obra serviu de modelo pouco tempo depois para Xenofonte, que escreveu Agesilau, que o próprio autor diz ser um épainos, um encômio das virtudes e glória do rei, distinguindo assim esta obra de sua da outra historiográfica, Hellenica. No elogio de Agesilau, Xenofonte organiza suas virtudes em um esquema gorgiano adotado também por outros socráticos. A obra Apomnemoneumata de Xenofonte, cuja tradução latina seria commentarii, é também interessante. Inicialmente a obra apresenta uma defesa legal de Sócrates, e no início do capítulo três Xenofonte afirma que "pretende mostrar como Sócrates ajudou em suas campanhas tanto com seus feitos como com suas palavras, relatando assim tudo que se lembra sobre ele"239. O gênero da obra seria assim inovador, combinando uma apologia com uma Memorabilia ou Commentarii, e coleção de ditos do filósofo. Talvez tal forma de introdução, feitos e ditos possa ter influenciado a forma da biografia. Mas, segundo Momigliano, a obra de Xenofonte que mais parece ter contribuído para o gênero biográfico é a Ciropédia. A obra descreve a vida do rei Ciro do começo ao fim e apresenta elogios de sua educação e de seu caráter, mas é, segundo o estudioso, uma novela pedagógica, que nunca reivindicou ser um relato verdadeiro de uma pessoa real, uma biografia fíctícia. Faço a ressalva de que Momigliano, a meu ver, também não está, embora pareça nesta diferenciação com a novela, supondo que a biografia seja um relato verídico. Assim como outros socráticos, Xenofonte valeu-se de uma matéria oriental para "negligenciar" a verdade histórica. Sua obra provavelmente era lida pelos leitores como de caráter ficcional. Para Momigliano, a obra não é exatamente uma biografia, sendo uma mistura de fatos e fantasias que comunicam uma mensagem filosófica; mas a existência da Ciropédia confirma que a biografia propriamente dita foi precedida ou pelo menos acompanhada, de maneira inspiradora, pela ficção. $\mathrm{O}$ historiador conclui assim que, mesmo após o século quarto, a separação entre fíç̧ão e realidade é menor na biografia que na história política, uma vez que informações interessantes ao relato biográfico (como educação, assuntos amorosos e caráter) eram muito menos

\footnotetext{
${ }^{238}$ Osley $(1946,9)$.

${ }^{239}$ Tradução nossa, a partir do trecho apud Momigliano $(1993,53)$.
} 
documentadas que guerras e reformas políticas. Os biógrafos tinham assim que recorrer à ficção. Stadter ressalta que Xenofonte nesta obra estabeleceu a virtude moral como um aspecto fundamental da biografia, através da representação das virtudes pessoais de Ciro como essenciais para sua liderança política e militar. O estudioso vê em Xenofonte os elementos antecedentes da biografia como um gênero: "tratamento da vida completa desde o nascimento até a morte, avaliação prática e moral do caráter e de sua relação com as realizações, atribuição de louvor e censura, uso de anedotas ilustrativas, e disposição para aprofundar o retrato com detalhes verossímeis". 240

Para Joseph Geiger ${ }^{241}$, entretanto, há uma clara distinção entre os encômios e a biografia política, que para o autor só surge com Cornélio Nepos. Segundo ele, o propósito de louvor do encômio o distingue, uma vez que sua organização é controlada pelas leis da retórica epidítica. Para o autor, a biografia política, diferentemente, tem a função de gravar os fatos, sendo um genus proximum da história. Hägg \& Rousseau ${ }^{242}$, em Greek Biography and Panegyric in Late antiguity, afirmam que biografia e encômio tiveram origens distintas no século quarto: encômio nasce na retórica epidítica com o Evágoras de Isócrates, enquanto a biografia, seria mais versátil, mascarada às vezes como uma carta, e teria sua origem nos relatos sobre a vida e memória de Sócrates, e nos retratos socráticos apresentados por Platão e Xenofonte, que eram mais retratos do que vidas estruturadas cronologicamente. Luciano de Samóstata, em Como se escreve a História, aconselha que o historiador deve evitar o louvor de governantes e generais em seu escrito ${ }^{243}$. Discordo aqui de que esta seja uma distinção estanque. Na prática, essas diferenças se dissolvem, e não cremos que a Retórica, mesmo epidítica, esteja completamente apartada de outros gêneros de prosa, principalmente da História. A retórica, como já tratamos no capítulo sobre a relação entre História e Retórica, não é alheia a outros escritos de prosa que não discursos oratórios. Aliás, o próprio Geiger, em algumas páginas anteriores de seu trabalho, justifica a dificuldade de investigar o surgimento do gênero biografia argumentando que os gêneros de prosa não possuíam uma distinção, uma teoria dos gêneros tão estabelecida quanto à poesia ${ }^{244}$.

\footnotetext{
${ }^{240}$ Stadter $(2007,529)$.

${ }^{241}$ Geiger ( 1985).

242 Hägg \& Rousseau(2000, 2-5).

${ }^{243}$ Luciano, Hist. Concr. 3-7; Cf. Wiseman (1993, 123).

${ }^{244}$ Geiger (1985, 13).
} 
Momigliano também reconhece como importante no século quarto a produção por parte dos Socráticos de cartas apologéticas, como a Carta 7 de Platão, uma verdadeira carta autobiográfica. $\mathrm{O}$ autor defende ainda a importância dos experimentos biográficos em tal século argumentando que a história Phlippica, de Teopômpo, organizou o relato dos eventos em torno de um indivíduo, Felipe da Macedônia, e como suas virtudes e vícios contribuíram para a história. Assim, segundo Momigliano, a ênfase na biografia trouxe para a historiografia maior atenção ao psicológico e um forte tom moral.

Mas após tal período, a atmosfera de Atenas muda com a vitória macedônica em 338 a.c., e a filosofia socrática cede lugar à Aristóteles e seus alunos. Nada podemos afirmar com exatidão sobre a produção de biografia pelos peripatéticos. Momigliano ressalta, entretanto, que é notável em seus escritos um interesse por anedotas, que ilustravam vícios e virtudes nas monografias sobre o assunto ${ }^{245}$. É visível também o interesse dos peripatéticos pela vida de escritores. Há livros sobre Píndaro e Safo, constituídos por interpretações históricas de passagens destes autores. Para Momigliano, não são biografias, assim como também não sãos as obras peripatéticas que descreviam e julgavam escolas filosóficas, como Vida dos Gregos, de Dicearco. É relevante também a produção peripatética de coleções de anedotas, como haviam feito antes os isocráticos Teopompo e Éforo, que coletaram anedotas de eventos e personalidades estranhas; coleções de respostas e comentários, e ainda coleção de exemplos, paradeigmata, que são tão antigos quanto Homero. Mas apenas fragmentos destes gêneros nos restam, que não permitem analisar quais as diferenças com a biografia helenística. Momigliano reconhece a dificuldade de separar tais coleções de anedotas e biografia, pois há uma dificuldade em determinar o propósito da pesquisa biográfica.

Mas Momigliano trata de obras e autores dos quais há mais evidências sobre a identificação com o gênero biográfico. São Jerônimo, no prefácio de De viris illustribus, aponta como predecessor do gênero Aristóxenes, Hermipo, Antígono de Caristo e Sátiro de Calate (“Apud Graecos Hermippus Peripateticus, Antigonu Carystius, Satyrus doctus vir et omnium longe doctssimus Aristoxenus Musicus". ${ }^{246}$ Dos quatro, apenas Antígono não esteve ligado aos peripatéticos, e mesmo os outros três tiveram relações incertas. Aristóxenes divergiu muitas vezes de Aristóteles, e não podemos generalizar sua obra como um produto aristotélico. Segundo Momigliano, ele provavelmente foi o primeiro a escrever biografia entre os peripatéticos, e teria escrito vidas de Pitágoras, Arquitas, Sócrates e Platão, com grande sensibilidade para valores morais e situações humanas com apurada capacidade de unificar

\footnotetext{
${ }^{245}$ Momigliano $(1993,69)$.

${ }^{246}$ Jerônimo, De viris illustribus, Prefácio, apud Momigliano (1993, 73).
} 
episódios dentro de um quadro biográfico. Aristóxenes teria influenciado Demétrio de Falero, que escreveu uma apologia de Sócrates, que não sabemos se era uma biografia, e também Fânias de Éreso, que, através do testemunho de Plutarco, sabemos que escreveu trabalhos com detalhes biográficos ${ }^{247}$.

Os três outros nomes citados por Jerônimo teriam escrito na segunda metade do século terceiro. Sabemos que Hermipo, discípulo de Calímaco, escreveu biografias de legisladores e sábios, e agrupou tais vidas em livros de acordo com a profissão. Um grande fragmento da vida de Pitágoras está preservado em Diógenes Laércio. Osley afirma que o tratamento de Hermipo é sempre da maneira formal peripatética, mas que há uma parcela anedotal em sua abordagem $^{248}$.

Sátiro escreveu biografias em forma de diálogo, conforme mostrou a descoberta do Papyrus Oryrhynchus 1176, publicado em 1912. A assinatura do papiro descreve assim a obra: Livro Seis do catálogo das vidas de Sátiros incluindo Èsquilo, Sófocles e Eurípides. Joseph Geiger ${ }^{249}$ defende que a forma dialógica da obra é um indício de que no período helenístico só havia biografia de intelectuais, pois dificilmente o diálogo seria adequado para uma biografia política. Mas falaremos mais adiante sobre as teses do estudioso.

Antígono de Caristo foi provavelmente discípulo de Menêdemo, fundador da escola Erétria. Também teria imitado Aristóxenes, e escreveu vidas de diversos filósofos. Momogliano cita ainda deste período o escritor Sócio, que viveu em Alexandria perto de 180 a c., e teria escrito também uma série de filósofos.

Diante de tais obras e autores, podemos concluir que a biografia de intelectuais já era um gênero consolidado no século terceiro. Mas Sátiro também escrevera sobre Filipe II e Dionísio o Jovem, de Siracusa ${ }^{250}$. Segundo Osley ${ }^{251}$, fragmentos da vida de Filipe estão presentes em Ateneu. Portanto, não são claros os limites entre encomia de figuras políticas, historiografia política e biografia de generais e reis neste período. Encômios de comandantes, seguindo Isócrates como modelo, continuavam populares. Políbio escreveu um encômio de Filopêmen, e Onesícrates sobre a educação de Alexandre.

\footnotetext{
$\overline{247}$ Cf. Momigliano ( 1993, 75-6).

${ }^{248}$ Cf. Osley $(1946,17)$.

${ }^{249}$ Geiger (1985, 42).

${ }^{250}$ Cf. Momigliano $(1993,83)$.

${ }^{251}$ Osley $(1946,18)$.
} 
Em período próximo a este existiram também diversas obras sobre a vida de Alexandre, como as obras de Calistenes e a já citada de Onesícrates. Osley ${ }^{252}$ afirma que duas Vidas de Alexandre que tiveram mais "mérito histórico" foram a de Ptolomeu (Sóter) e Aristóbulo, mencionados como dignos de confiança por Árrio em sua Anabasis. Mas Cares de Mitilene, oficial da corte de Alexandre, teria escrito uma obra que reunia anedotas da vida pessoal de Alexandre, obra a quem se referiu Ateneus posteriormente. Mas seriam tais obras encômios, monografias histórias centradas em uma única pessoa, ou biografias políticas? Quais as diferenças entre tais gêneros neste período?

Momigliano afirma que uma separação estanque entre encômio de uma personalidade política e biografia política é impossível. Pensamos que talvez o encômio não abarcasse necessariamente toda a vida do biografado como a biografia, ou talvez a biografia não fosse necessariamente sempre um elogio. O caráter encomiástico e a seleção do material seria então um diferencial, mas não necessariamente. E o que diferenciaria a biografia de uma monografia centrada em uma pessoa? Para Momigliano os memorialistas das guerras alexandrinas e os historiadores de reis helenísticos estão em uma posição ambígua entre biografia e história.

Entretanto, justamente por esta proximidade entre biografia política e história, é discutível se houve biografia política antes de Cornélio Nepos. Geiger defende que não houve biografia política no período helenístico. O autor defende que há inúmeras evidências indiscutíveis sobre a existência de biografias de intelectuais, mas que é discutível se os escritos helenísticos sobre reis e generais citados por Momigliano constituíam-se como um novo gênero, mas que deviam ser considerados história. Para o autor, tal existência não é atestada no período helenístico, o que justificaria a preocupação de Nepos, tido então como inaugurador da biografia política, em diferenciar seus escrito da história ${ }^{253}$.

Alguns defendem, como Stadter, que algumas histórias de Alexandre provavelmente eram já consideradas vidas, e que o Philopoemen de Políbio representaria o exemplo mais provável de uma biografia política no período ${ }^{254}$. A esta obra Políbio se refere nas Histórias, 10.21.5-8:

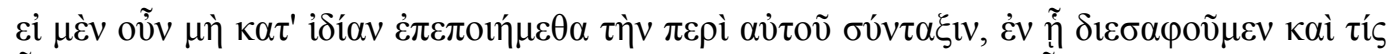

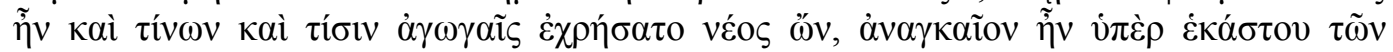

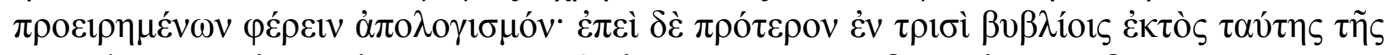

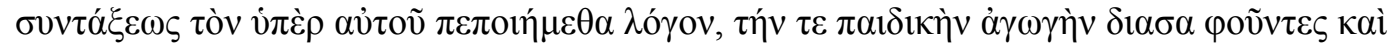

\footnotetext{
${ }^{252}$ Cf. Osley $(1946,14)$.

${ }^{253}$ Cf. Geiger (1985, 22-51).

${ }^{254}$ Stadter (2007, 531).
} 


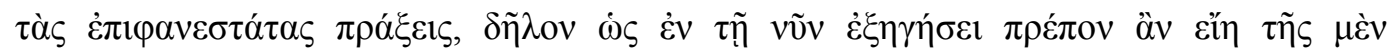

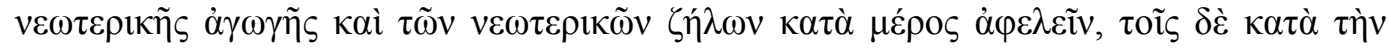

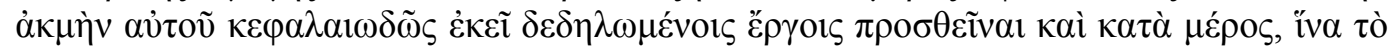

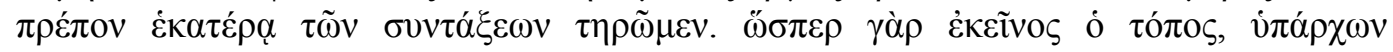

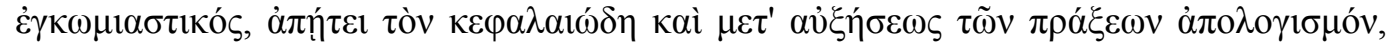

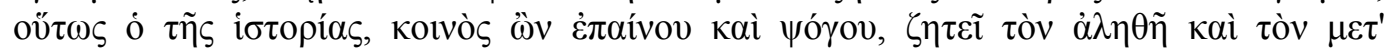

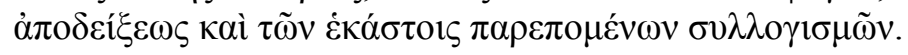

Se eu não tivesse escrito sobre Filopêmen uma obra à parte, onde revelo quem era ele $\mathrm{e}$ de que família provinha, e a natureza de sua formação quando jovem, ser-me-ia necessário expor todos esses aspectos agora. Mas, considerando que já lhe dediquei anteriormente uma obra em três livros (ela não faz parte desta História), onde exponho a sua formação desde menino e enumero seus feitos mais famosos, é óbvio que na presente narrativa o procedimentos adequado é omitir detalhes relativos à sua formação inicial e às ambições de sua juventude, e em vez disso acrescentar detalhes à exposição resumida que fiz nessa obra à parte acerca de seus feitos na maturidade, pois assim o caráter próprio a cada obra poderá ser preservado. De fato, assim como o tratamento anterior, escrito em forma encomiástica, impunha uma exposição sumária e um tanto exagerada de seus feitos, a presente História, onde são distribuídos imparcialmente louvores e censuras, impõe um relato rigorosamente verídico, no qual é apresentado o fundamento de cada louvor e de cada censura, acompanhado em cada caso dos comentários pertinentes ${ }^{255}$.

Stadter vê neste trecho a possibilidade de que esta outra obra de Políbio fosse uma bios. Mas Geiger argumenta que uma rígida interpretação do trecho nos leva a crer que o Philopoemen de Políbio era um encômio (o enkomium, segundo o autor difere da bíos pelo caráter encomiástico e por ser regido pelas leias da retórica epidítica ${ }^{256}$ ), uma vez que, se o gênero bíos fosse corrente para descrição de generais e reis, Políbio poderia ter descrito sua obra como vida. Esta interpretação de Filopêmen estaria em analogia com o enkomium de Agesilau xenofontiano ${ }^{257}$. A distinção proposta por Políbio é entre encômio e História, que, na visão do historiador, deve distribuir louvor e vitupério imparcialmente.

Políbio considera tal obra um encômio, mas na prática, se a obra abordasse a vida de Filopêmen do início ao fim, em que seria distinta do gênero biografia? Dissolvendo-se a distinção estanque entre enkomium e vita, considerando que seus limites também não são tão sólidos, e pensando que o encômio pode ser um gênero que o influenciou, o trecho de Políbio pode ser analisado tendo em vista a distinção entre bíos e historía. Segundo Gentili \& Cerri ${ }^{258}$, Políbio neste trecho define aqueles elementos da informação biográfica que poderiam ser usados dentro dos limites do método historiográfico. Políbio só não se dedica à formação da juventude de Filopêmen porque já fez isso em outra obra. Ele não está rejeitando os fatos

\footnotetext{
255 Plb. 10.21.5-8. Tradução de Mário da Gama Kury (1985).

${ }^{256}$ Cf. Geiger $(1985,16)$

${ }^{257}$ Geiger (1985, 35-6).

${ }^{258}$ Cerri \& Gentili $(1988,65-6)$.
} 
biográficos, mas sim a tendência encomiástica que seria própria de uma monografia para louvor de um homem. Tais estudiosos, pois, concluem deste trecho que a distinção entre biografia e história se assentava na seleção dos dados biográficos: na biografia são orientados em direção à reconstrução da formação educacional e, na história, em direção à causa dos eventos políticos e militares. Desta maneira, para os estudiosos, não há verdadeiramente uma dicotomia, nem divórcio em Políbio entre narrativa histórica e biográfica, mas apenas uma "interação entre os dois gêneros, com diferente acentuação em um e em outro de acordo com o tipo de trabalho escrito"259. Podemos observar, entretanto, que para Políbio esta outra obra, seja ela um encômio ou uma bios, difere da história pois esta apresenta um relato estritamente verídico, em que os elogios e vitupérios estão fundamentados.

Geiger tenta distinguir a monografia política da bios política argumentando que a monografia política não necessariamente abarca uma vida desde o nascimento até a morte, e que, diferente do que ocorre na biografia, os relatos de cercos e batalhas são indispensáveis na historiografia política ${ }^{260}$. Mas o autor reconhece que mesmo a historiografia não teve regras tão definidas, o que pode ser depreendido da necessidade de cada historiador explicar suas regras nos prefácios. Parece ser consenso, entretanto, que a diferença entre os gêneros está na seleção do material, no enfoque. Entretanto, alguns trechos de Nepos e Plutarco podem contribuir para nossa análise da distinção entre bios e história. Passemos então para o estudo do gênero entre os romanos.

Momigliano observa que é abundante entre os romanos, tanto no período republicano quanto no imperial, de Commentarii de vita sua, o que nos remete ao gênero da autobiografia. Como sabemos, a tradição republicana fundava-se no exemplo dos antepassados, no "exempla maiorum". Neste contexto, relatos que criavam retratos de homens virtuosos tinham grande importância. As imagens fúnebres dos ancestrais, os discursos fúnebres devem ter impulsionado de certa forma a produção de biografia, mas o pesquisador afirma que somente há evidências fracas sobre esta relação. Em uma quase digressão, comenta que este "gosto" romano pela autobiografia talvez esteja ligado ao fenômeno do retrato realístico (ou verista) do último século republicano romano, mas o autor não se aprofunda no assunto, pois afirma que não há consenso entre os estudiosos sobre o surgimento do retrato verista.

A biografia em Roma, segundo Momigliano, foi transformada em benefício do estabelecimento aristocrático, e durante a ditadura de Júlio César tornou-se expressão das mais complexas atitudes da classe dominante diante dos valores romanos e estrangeiros.

\footnotetext{
${ }^{259}$ Idem, p.66, tradução nossa.

${ }^{260}$ Geiger $(1985,16)$.
} 
Segundo São Jerônimo, os primeiros biógrafos latinos teriam sido Varrão, que teria escritos De poetis, obra perdida, e Imagines, que sabemos que fora uma coleção de figuras de homens famosos acompanhadas de um epigrama que caracterizava o retratado, Santra, de quem pouco sabemos, e Cornélio Nepos.

Momigliano afirma que Nepos desenvolveu a noção biográfica de Varrão. Nepos era amigo de Ático, e frequentavam o circulo de artistas da vila tanfiliana, cuja preocupação principal era a história. Ático também teria escrito uma coleção de retratos com epigramas, como Varrão (Nep. Att. 18.5-6). Segundo Momigliano ${ }^{261}$, os três autores não eram patriotas no sentido augustano, pois tinham interesses mais internacionais e humanos nas suas biografias. Nepos deu à biografia uma nova dimensão, ao torná-la um meio de comparação entre homens e eventos gregos e romanos, o que teria ajudado a criar uma civilização cosmopolitana. Nepos seria assim o antecedente de Plutarco no que diz respeito às vidas paralelas.

A biografia ganha maior prestígio no período imperial, porque, segundo Momigliano, o gênero era a forma natural de contar a história de um César, e também porque era um veículo não ortodoxo de ideias políticas e filosóficas. Momigliano afirma que a biografia contribuiu para manter os imperadores dentro dos limites da mortalidade. E mantendo a biografia e história separados, tanto os gregos quantos os romanos puderam apreciar a vida de poetas, filósofos e santos, e também puderam apreciar o que permanecia de humano em um rei ou político.

Para Momigliano, Nepos também foi responsável por familiarizar os romanos com a distinção helenística entre história e biografia. Voltemos então à discussão sobre os limites entre bíos e história. No Prefácio do livro dos generais estrangeiros, Nepos aponta o gênero que ele irá escrever não é considerado, por muitos, digno ou decoroso, para tratar de tão grandes generais:

Non dubito fore plerosque, Attice, qui hoc genus scripturae leve et non satis dignum summorum virorum personis iudicent, cum relatum legent, quis musicam docuerit Epaminondam, aut in eius uirtitibus commemorari, saltasse eum commode scienterque tibiss cantasse".

Não duvido, Ático, que haverá muitos que julgarão leve este gênero de escrita e não suficientemente digno do caráter dos homens ilustres, quando lerem o relato sobre quem ensinou música a Epaminondas, ou quando for lembrado que, entre as suas virtudes, ele dançava bem e tocava habilmente flauta ${ }^{262}$.

\footnotetext{
${ }^{261}$ Momigliano $(1993,98)$.

262 Nep. Praef.1. Tradução de Renato Ambrosio, apud Ambrosio (2005, 74).
} 
Notamos que neste trecho parece haver para Nepos uma clara delimitação do gênero que irá escrever, bem como no início da Vida de Pelópidas:

Pelopidas Thebanus, magis historicis quam vulgo notus. Cuius de virtutibus dubito, quemadmodum exponam, quod vereor; si res explicare incipiam, ne non vitam eius enarrare, sed historiam videar scribere; sin tantum modo summas attigero, ne rudibus Graecarum litterarum minus dilucide appareat quantus fuerit ille vir. Itaque utrique rei occurram, quantum potuero, et medebor cum satietati tum ignorantiae lectorum ${ }^{263}$.

Pelópidas, tebano, conhecido mais pelos historiadores que pelo povo. Não sei de que maneira exponho as suas virtudes, pois temo que, se eu começar pelo relato de seus feitos, parecerá que não narro sua vida, mas que escrevo história; mas se apenas abordar superficialmente feitos mais importantes, temo que aos leitores inexperientes nas Letras Gregas será menos evidente quão grande foi aquele homem. E assim, irei ao encontro de ambas as dificuldades fazendo o possível, e darei remédio tanto ao enfado quanto à ignorância dos leitores.

Nessa passagem, Nepos associa o escribere historiam ao explicare res, em oposição ao enarrare vitam. As res, os feitos e acontecimentos geridos, parecem ser vistas pelo autor como objeto da história.

Geiger afirma que a passagem do Prefácio do livro dos generais estrangeiros é erroneamente interpretada quando aplicam as qualificações de Nepos a todo o gênero biográfico; Geiger defende que se aplicam apenas à biografia política: "Hoc genus scripturae is, of course, biography: but it may be judge leve et non satis dignum only if applied to the lives of summi viri." ${ }^{264}$. Para o autor, Nepos diz isso justamente porque o gênero não era comum a figuras políticas, que eram antes somente objeto da historiografia, ou até mesmo da épica. O gênero não seria até então apto para a biografia de generais, mas somente para a vida de intelectuais, e por isso, segundo Geiger, faz-se necessária tal ressalva de Nepos. Ao tratar da passagem ilustre na Vida de Pelópidas, e tendo em vista também as distinções de Plutarco que veremos abaixo, Geiger também defende que a diferenciação aplica-se somente à biografia política, uma vez que somente sendo gêneros próximos, precisariam ser diferenciados história e biografia política, pois poetas e teatrólogos não eram objeto da história, pois a história era essencialmente história política ${ }^{265}$.

Renato Ambrosio, entretanto, em estudo dedicado aos exórdios da historiografia em Roma, analisa o prefácio de Cornélio Nepos de maneira diferente. O pesquisador destaca que o genus scripturae leue et non satis dignum refere-se à personis, ou seja, ao caráter ou papel

\footnotetext{
${ }^{263}$ Nep. Pelop., 1.1. (Tradução nossa).

${ }^{264}$ Geiger $(1985,113)$.

${ }^{265} \mathrm{Idem}$, p.115.
} 
dos homens ilustres. O tipo de biografia não seria então decoroso ao tema das vidas dos chefes estrangeiros. Ambrosio defende que o motivo desta falta de decoro é o fato de Nepos relatar aspectos da vida dos biografados que poderiam ser criticados pelos leitores. Assim, entende-se o primeiro parágrafo do prefácio: o gênero poderá ser considerado não adequado ao lerem quem ensinou música a Epaminondas e que ele dançava. Como veremos logo mais, Nepos falará também no Prefácio, e também em outros momentos, a necessidade de não julgar os costumes estranhos com olhos romanos. Segundo Ambrosio, seria então o relato dos costumes estranhos que poderá fazer com que o leitor não versado nas letras gregas considere um gênero não digno do papel destes homens ilustres.

Assim, a leitura de Ambrosio nos leva a pensar em uma distinção entre biografia e história no que concerne à matéria. Se o genus escripturae de Nepos, que abarca aspectos de costumes estranhos, entre eles elementos da vida "pessoal", não era digno do papel social dos comandantes estrangeiros, seria a história então o genus scripturae adequado? Se pensarmos que a história relata essencialmente eventos políticos e militares, sim. Mas como sabemos, a historiografia também dedicava-se aos costumes estrangeiros, como facilmente podemos constatar nas Histórias de Heródoto. Desta maneira, cremos que pouco pode ser depreendido com certeza do prefácio nepotiano com relação à distinção biografia e história. Entretanto, a partir do trecho inicial da Vida de Pelópidas parece ficar claro que, para Nepos, se apenas houver narrativa dos feitos, seu escrito parecerá história. A mesma distinção talvez fique mais clara no seguinte trecho de Plutarco:

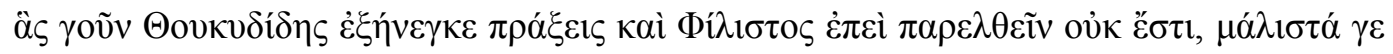

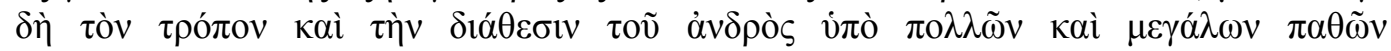

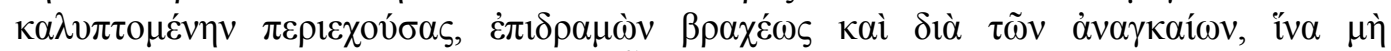

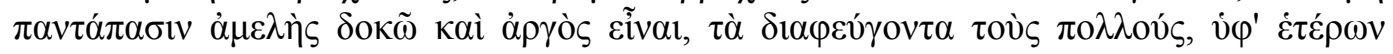

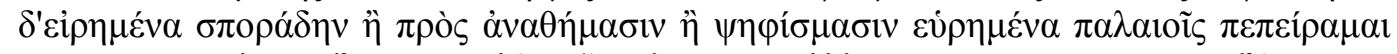

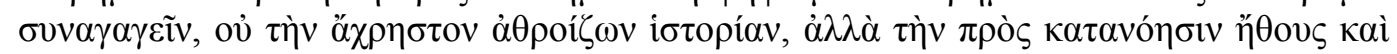

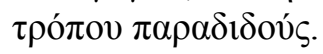

Isso posto, não podendo omitir as ações contadas por Tucídides e Filisto sobretudo porque esclarecem o caráter e as disposições do personagem, dissimulados sob o número e a magnitude de suas vicissitudes, mencionarei as essenciais a fim de não parecer omisso e preguiçoso. Todavia, aquilo que quase todos ignoram por estar disseminado nas obras de outros escritores ou inscrito em monumentos consagrados e antigo decretos, eis o que fiz questão de coletar não para compor uma história inútil, mas para oferecer algo que leve à compreensão de um caráter, uma conduta ${ }^{266}$.

Plutarco, no início da à Vida de Nícias, parece distinguir da História seu escrito por oferecer ao leitor o material que leve à compreensão de um caráter e conduta. Plutarco afirma

${ }^{266}$ Plu. Nic. I.5. Tradução de G. C. Cardoso (1991). 
que apenas relatará as ações essenciais já narradas por Tucídides e Filisto, e diz que reunirá elementos espalhados pela narrativa dos outros autores, e ainda em monumentos e decretos antigos. Parece-nos que Plutarco na biografia, assim, reorganizará os acontecimentos e dados acerca da vida de Nícias de maneira a compor um relato útil à compreensão de um êthos. $\mathrm{O}$ material é assim selecionado e organizado de maneira subordinada à construção de um caráter. Ele não está interessado em esgotar tudo o que se sabe sobre a persona; essa seria talvez a tarefa do historiador. Parece-nos relevante também a afirmação de que o biógrafo reunirá aspectos geralmente ignorados. Imaginamos que sejam aspectos ignorados pela história, como anedotas e acontecimentos da vida pessoal, elementos que geralmente não são objeto da historiografia tradicional, essencialmente política e militar (tal diferença talvez não seja tão evidente quando comparadas biografia e historiografia isocrática ${ }^{267}$ ). Para Cerri \& Gentili, Plutarco demonstra grande consciência da diferente abordagem dos dois tipos de narrativa de acordo com as diferentes funções do biógrafo e do historiador. ${ }^{268}$

Vejamos ainda mais um trecho de Plutarco, Prefácio às Vidas de Alexandre e César, que expõe as diferentes abordagens:

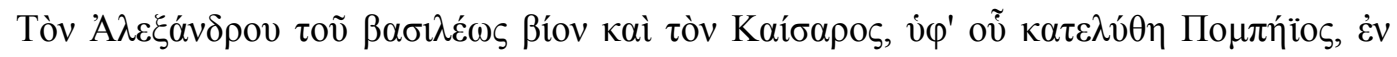

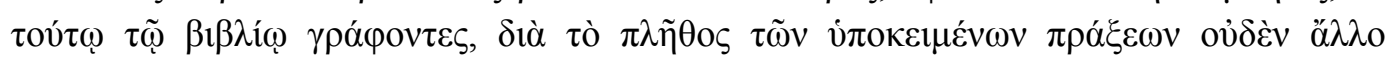

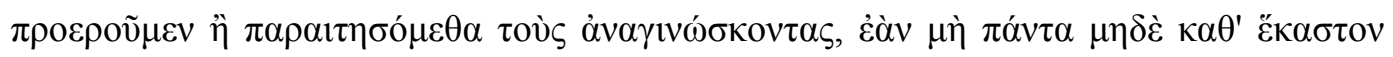

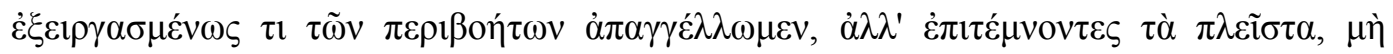

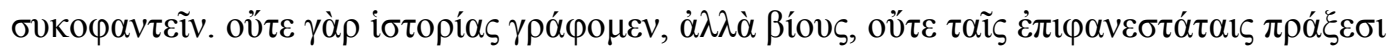

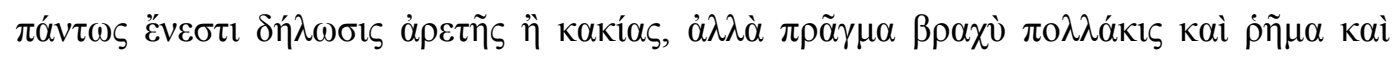

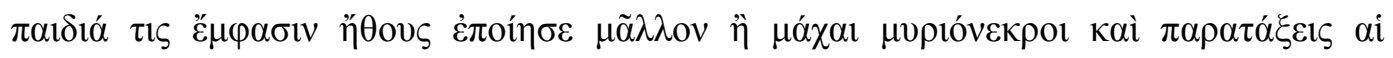

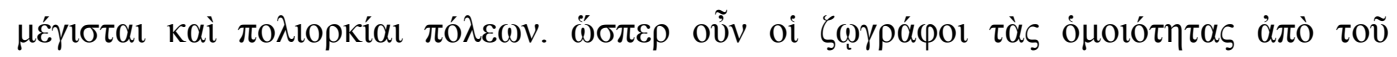

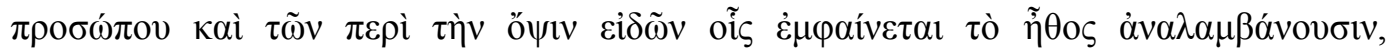

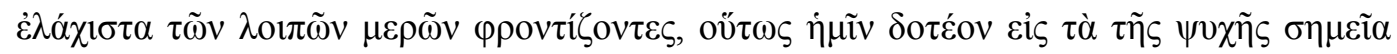

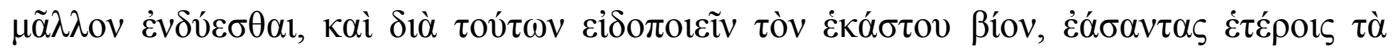

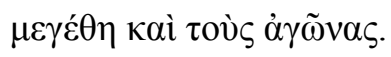

Escrevemos, neste livro, a Vida do rei Alexandre e a Vida de César, que desafiou Pompeu. Como único preâmbulo, dado o número infinito de fatos que constituem a matéria, limitamo-nos a pedir aos leitores que não nos censurem se, em lugar de expor ampla e pormenorizadamente cada acontecimento, ou algum dos atos mais memoráveis, damos aqui, apenas, um simples sumário da maior parte deles. Com efeito, não escrevemos história, mas Vidas. Nem sempre, aliás, são as ações mais brilhantes as que mostram melhor as virtudes ou os vícios dos homens. Muitas vezes, uma pequena coisa, a menor palavra, um gracejo, fazem ressaltar melhor um caráter do que combates sangrentos, batalhas campais e ocupações de cidade. Assim como os pintores, em seus retratos, procuram fixar os traços do rosto e o olhar, refletindo nitidamente a índole da pessoa, sem se preocuparem com outras partes do corpo, assim também se permitirá que

\footnotetext{
${ }^{267}$ Cf. Cerri \& Gentili $(1988,64)$.

${ }^{268}$ Cerri \& Gentili $(1988,67)$.
} 
concentremos nosso estudo, principalmente, sobre as manifestações características da alma, e esbocemos, de acordo com esses sinais, a vida dessas duas personagens, deixando a outros os grandes acontecimentos e os combates ${ }^{269}$.

Assim como no excerto anterior, Plutarco neste trecho afirma que a narrativa dos acontecimentos será sumária. Plutarco parece opor duas maneiras de construir um caráter: uma na qual há o relato amplo e pormenorizado de acontecimentos, descrição de combates sangrentos, batalhas campais e ocupações da cidade, e outro, no qual estão presentes "pequenas coisas, a menor das palavras, ou um gracejo" que podem ressaltar um caráter. A primeira é a maneira da história, a segunda, da biografia plutarqueana. Para o biógrafo, as ações grandiosas nem sempre pintam o caráter tão bem como "coisas pequenas". A biografia, assim, dedica-se também à ações, comportamentos talvez considerados poucos dignos e importantes para serem relatados pela história, entendendo que essa era mais centrada em ações públicas, grandiosas, como batalhas. O biógrafo compara seu trabalho ao do pintor, que pinta um caráter através de uma parte, e não do todo, mas uma parte que era capaz de refletir a índole, o rosto e o olhar.

Nepos, no início da vida de Epaminondas, parece considerar a caracterização animi mais importante que o relato as ações:

Cum autem exprimere imaginem consuetudinis atque vitae velimus Epaminondae, nihil videmur debere praetermittere quod pertineat ad eam declarandam. Qua re dicemus primum de genere eius, deinde quibus diciplinis et a quibus sit eruditus, tum de moribus ingeniique facultatibus et si qua alia memoria digna erunt, postremo de rebus gestis, quae a plurimis animi anteponuntur virtutibus (Nep. Ep. 1.3-4).

Uma vez que desejamos descrever o retrato da vida de Epaminondas e de seus hábitos, parece-nos que não devemos omitir nada que seja pertinente para evidenciá-lo. Assim, relatamos primeiramente sobre sua origem, e depois em quais disciplinas e com quais professores foi educado, e então sobre seu caráter e habilidades do engenho, e outras coisas dignas de memória; por fim, sobre seus feitos, considerados, por muitos, primeiros às virtudes da mente.

Neste trecho, fica claro que, para Nepos, o relato das res gestae deve estar subordinado à descrição do caráter na biografia, pois os feitos serão tratados por último ${ }^{270}$. Observamos que a ordem do relato preceituada pelo biógrafo ecoa a preceituação dos manuais de retórica quanto à ordem do elementos a serem abordados na construção do discurso epidítico. De fato, se pensarmos na biografia como um retrato verbal, uma imago consuetudinis atque vitae, como diz Nepos no trecho acima, com isso compondo elogios e

\footnotetext{
${ }^{269}$ Plu. Comp. Alex.Caes. Preâmbulo. (Tradução de Hélio Vega).

${ }^{270} \mathrm{Cf}$. Titchener $(2003,88) .0$ autor também depreende deste trecho que Nepos valoriza mais a estratégia que a força física.
} 
vitupérios, estamos no âmbito do genero de discurso epidítico. Embora a história valha-se frequentemente deste gênero, ela é por essência também ligada ao gênero de discurso judiciário, ao investigar se um acontecimento ocorreu e de que maneira.

Devemos mencionar, entretanto, um estudo recente sobre as biografias de Plutarco que tenta eliminar a diferenças entre biografia e história como proposta no Prefácio da Vida de Alexandre. Maria Aparecida Oliveria Silva ${ }^{271}$ defende que as vidas de Plutarco são história, alegando que Plutarco desenvolveu um trabalho de historiador na coleta, seleção e registro das informações colhidas, e pensou a história de Esparta por meio da composição das biografias de espartanos ilustres. Entretanto, Luiz Otávio de Magalhães ${ }^{272}$, resenhando tal obra, rebate suficientemente as ideias da autora, demonstrando que a pesquisa que Plutarco realiza com base em fontes historiográficas não garantiam a "busca pela verdade", algo pelo que os historiadores gostavam de ser conhecidos, mas que sabemos não poder ser totalmente atingido, e que a história da pólis está em segundo plano na narrativa de Plutarco, pois claramente em primeiro plano está a descrição dos caracteres dos biografados, e não em todas as biografias o cenário é Esparta.

Concluímos dos trechos antigos analisados que, a história relata todos os acontecimentos de um dado momento, enquanto a biografia narrará somente aqueles pertinentes para a construção do êthos do biografado. O foco é ético e abarca a vida do início ao fim. Segundo Momigliano, o historiador não precisa ser seletivo, aliás, tem a obrigação de não ser (considerando apenas eventos políticos e militares). O biógrafo sim deve selecionar somente fatos relevantes para a vida ${ }^{273}$. Em Cornélio Nepos, os acontecimentos estão resumidos, selecionados e dispostos de maneira a criar determinada imagem dos generais, sendo que o gênero poderia conter anedotas e informações sobre outros aspectos que não públicos e políticos. Entretanto, como veremos através do estudo da Vida de Aníbal, sua biografia contém essencialmente político e militares, talvez porque seria difícil Nepos obter dados da vida "privada" de generais tão distantes temporal e espacialmente de si. O caráter anedótico torna-se mais evidente com Suetônio e Plutarco.

Como vemos, a partir de Nepos, torna-se mais clara a distinção entre bíos e história, distinção essa, sobretudo, assentada na seleção e subordinação dos fatos ao caráter. Entretanto, os limites podem muitas vezes se sobrepor. Cerri \& Gentili, em History and

\footnotetext{
${ }^{271}$ Silva (2006).

${ }^{272}$ Magalhães (2009, 181-187).

${ }^{273}$ Momigliano $(1993,11)$.
} 
Biography in Ancient Thought, mostram como uma separação estanque é difícil. Os autores argumentam que interesses biográficos perpassam também as obras historiográficas, pois são inseparáveis das causas dos fatos, e afirmam que mesmo para os gregos já existia a oposição entre história universal e história seletiva. Como já dissemos, os limites se tornam ainda menos claros quando pensamos na existência de uma vertente da historiografia que tratava também de assuntos "privados", a vertente da "historiografia isocrática"; (segundo os dois estudiosos a historiografia isocrática estava em clara oposição ao tipo uniforme da historiografia, centrada exclusivamente em fatos políticos e militares ${ }^{274}$ ). Assim, seria da historiografia em sua concepção predominante, a da historiografia política, que Nepos e Plutarco propõem uma diferenciação com sua obra. Cerri \& Gentili questionam, diante desta dificuldade, se deveríamos definir a biografia não como um relato das ações de um indivíduo, mas como uma descrição da natureza do indivíduo considerada na unidade de suas ações e palavras $^{275}$. E acrescentam que deveríamos entender que a narrativa biográfica varia com relação às funções específicas que ela assume em contextos históricos particulares e diferentes sistemas literários.

A biografia helenística, afirma Momigliano, não era uniforme. Serviu para caracterizar um filósofo individualmente, poeta, artista ou ainda a escola a qual pertenciam. E se o indivíduo em questão era um rei ou político, a biografia manteve-se perto da História política. Segundo Stadter, a noção do gênero biografia separado da história depende de um pacto entre autor e leitor que é renegociado em cada obra ${ }^{276}$. Assim o autor conclui sobre a relação entre biografia política e história:

Speaking generally, political biography represents the personal approach to history. Its focus is not on larger elements of causation, such as the constant seesaw of action and retribution and the limits of human nature seen in Herodotus and Thucydides, but on the personal. It asks what kind of character a historical actor possessed, what motivated his behavior, what he accomplished or failed to achieve. Passing over large-scale movements and consequences, it tends to focus on details and anecdotes. Authorial comments are more frequent than is usual in history, but speeches are rare. Narrative, in particular, is more episodic, or completely excluded. In general, it is not that biography is less accurate or more interpretive than history, but that its scope are different, even when it uses the same sources ${ }^{277}$.

\footnotetext{
$\overline{{ }^{274} \text { Cerri \& Gentili }(1988,64)}$.

${ }^{275}$ Cerri \& Gentili $(1988,80)$.

${ }^{276}$ Cf. Stadter (2007, 528).

${ }^{277}$ Stadter (2007, 540).
} 
Quando tratamos da historiografia, observamos que um dos afazeres do historiador era investigar as causas da guerra, e assim a narrativa organiza os acontecimentos em um nexo causal. Stadter consegue ver nisso uma distinção com a bíos, que, por ter o foco no indivíduo, não opera com um sistema causal amplo como o da história. Nesse sentido, ela também não pode conter ensinamentos políticos. Stadter resume bem neste trecho algumas diferenças que, como vimos ao longo deste capítulo, apontam para a distinção entre história e bios: o foco da biografia está no caráter indivíduo, as ações descritas, sumariamente, de forma episódica, cooperam para a construção do caráter, e podem valer-se de detalhes e anedotas. Acrescentamos que, por incluir anedotas e detalhes da vida pessoal, a biografia tende a usar mais da ficção que a história, uma vez que este tipo de informação é mais difícil de estar documentada do que eventos políticos e militares. Mas a identificação de um material sobre a vida de um político ou militar como biografia torna-se mais fácil quando está enquadrada em uma série de vidas. É o que acontecerá com os biógrafos romanos.

\subsection{As vitae de Cornélio Nepos}

Pouco se sabe sobre a vida de Cornélio Nepos. Segundo Ausônio (Epist. 24), nasceu na Gália Cisalpina. Plínio (Hist. Nat. 3.18), entretanto, refere-se a ele como Padi accola, que significa perto de rio Pó, que poderia ser a cidade de Pávia. Mas viveu a maior parte de sua vida em Roma. Os estudiosos afirmam que teria vivido entre 99 a aprox.. 24 a. C.. Nepos provavelmente não exerceu nenhuma magistratura, segundo pode ser depreendido de uma carta de Plínio (Epist. 5.3.6). Não exerceu cargo político, mas era amigo de Ático e talvez de Cícero, e teria dedicado sua vida à publicação e escrita literária ${ }^{278}$.

Através de testemunhos, sabemos que escreveu outras obras além das vidas De Viris Illustribus, da qual nos restaram apenas o livro dos generais estrangeiros e duas vidas do livro dos historiadores romanos ${ }^{279}$. Plínio (Epist. 5.3.6), menciona uma obra de poemas do autor. Catulo, em sua dedicação, menciona três livros no qual Cornélio Nepos escrevera a história do mundo até 54, trata-se da obra Chronica. Aulo Gélio (6.18.11) e Suetônio (Aug. 77) referem-se à obra Exempla, uma coleção de anedotas para uso de rétores. Aulo Gélio menciona ainda uma Vida de Cícero (15.28.2), e o próprio Nepos afirma que escreveu uma vida de Catão mais extensa que àquela presente no livro sobre os historiadores romanos. Plínio Velho ainda menciona um tratado geográfico de Cornélio Nepos (Nat. 5.4).

\footnotetext{
${ }^{278}$ Rolfe, in: Cornélio Nepos (1984, viii).

${ }^{279}$ Cf. Sage ( 1978) para estudo da provável estrutura da obra De Viris Illustribus.
} 
Muitos estudiosos acreditam que Nepos foi considerado em sua época um escritor medíocre. A visão negativa da obra de Nepos, tanto no que diz respeito à escrita e ao conteúdo, é encontrada a partir do século XIX. O prefácio do comentário de Nipperdey, de 1849, frequentemente reeditado, inclusive recentemente pela Weidmann (2002), aconselhava aos professores alertar os alunos sobre frequentes erros factuais e evitar as vidas menos qualificadas $^{280}$. Mas mais agudos são os ataques de Nicholas Horsfall em Cambridge History of Classical Literature ii (Cambridge, 1982) e na introdução à edição Cornelius Nepos: a Selection (Oxford, 1993) 281 . O estudioso considera-o um "pigmeu intelectual” se comparado aos autores da época, de vocabulário limitado, que fez uso de exageros absurdos, inclinado ao lugar-comum no que se refere à crítica moral, de erros factuais e linguísticos, entre outras acusações. Alguns depreendem que Nepos era pouco conhecido e um autor sem prestígio em sua época através de uma carta de Cícero a Ático (16.14.4), na qual Nepos é apresentado como de pouca importância. Mas as interpretações dos críticos sobre tal carta são muito variadas. Titchener ${ }^{282}$ afirma que pouco pode ser concluído desta carta uma vez que não temos a carta da contrapartida de Ático.

Entretanto, há elogios ao autor em Aulo Gelio (Noites Áticas, 15. 28), São Jerônimo (Crônica a Eusébio) e Catulo, embora se discuta se a passagem do último é irônica ou não. Moreno, tradutor e prefaciador da edição espanhola pela Gredos, aponta que a latinidade do autor é medíocre, principalmente quando comparada a de Cícero, e vê nas Vidas incongruências na união do necessário com o anedótico e fútil, além de uma desordem na exposição das ideias. Rolfe diz que seu vocabulário é limitado e as sentenças sempre breves. Os principais procedimentos retóricos encontrados são a clausulas rítmicas, aliterações e antíteses. Entretanto, todos reconhecem que a qualidade da Vida de Ático é melhor. Joseph Geiger defende que a série dos generais pode ser uma exceção no que diz respeito à má qualidade de Nepos, e que os elogios dos contemporâneos podem não ser, portanto, irônicos, como interpretam alguns estudiosos recentes.

Entretanto, Nepos não pode ignorado quando se vai estudar a biografia latina. Geiger $^{283}$ defende ao longo de seu trabalho que Nepos foi um autor que tentou inovar. Como já foi dito, para Geiger, Nepos foi o primeiro a escrever biografia política. O autor argumenta

\footnotetext{
${ }^{280}$ Dionisotti $(1988,35)$.

${ }^{281}$ Ver Titchener (2003, 92-9), contra as acusações de Horsfall.

282 Titchener $(2003,95)$.

${ }^{283}$ Geiger (1985, 68-72).
} 
a favor do caráter inovador de Nepos dizendo (além do argumentum e silentio do não conhecimento de obras anteriores nomeadas claramente de vidas de políticos e militares), que a obra Chronica, aludida por Catulo (Carm. 1.1) e Vosio (De Historicis Latinis 1.14), foi a primeira a escrever em língua latina um trabalho historiográfico, ou antiquariano, que não tratava apenas da história latina; e que em Exempla, Nepos teria acrescentado material latino ao gênero grego, e a provável existência de um trabalho de geografia do autor, e a inovação ao comparar generais romanos e gregos, também apontaria para um gosto por um novo tema e pela adaptação de gêneros literários gregos e tradições às circunstâncias romanas. Geiger assim conclui sobre o biógrafo:

Cornelius Nepos, a writer of medíocre standards but possessed of keen sense of the needs of and opportunities provided by the Roman reading public, had already experimented with number of literary genres new to Latin literature when he started to work on a long biographical series. It was towards the end of that series, with Nepos possibly unaware of the importance of his innovation, that he came to add a pair of books on Roman and on Greek (later Foreign) Generals. Thus, political biography was born: it was left to a later age, the Roman Empire, to provide the social and political context in which political biography could flourish and attain its highest development, eventually to all but supplant historiography. ${ }^{284}$

Titchener sugere que as acusações contra as imprecisões de Nepos, contra a tendência moralizante e o limitado latim (acusações semelhantes às que também sofrera Plutarco), poderiam ser ataques relacionados à natureza da história e da biografia. A última provavelmente era considerada inferior, menos séria e "verídica". O artigo de Dionisotti (1988), no entanto, consegue ressuscitar Nepos das cinzas nas quais o colocaram muitos críticos. O estudioso enxerga que as vidas de Nepos tem muito a nos dizer sobre como um cidadão romano, em contato com os negócios públicos, mas não diretamente envolvido neles, entendia e interpretava o colapso do sistema político romano. Vejamos então qual teria sido o propósito de Nepos aos escrever a vida dos homens ilustres, e mais especificamente o livro dos generais estrangeiros, dedicado a Ático. No Prefácio do livro, pouco pode ser depreendido:

Non dubito fore plerosque, Attice, qui hoc genus scripturae leve et non satis dignum summorum virorum personis iudicent, cum relatum legent quis musicam docuerit Epaminondam, aut in eius virtutibus commemorari, saltasse eum commode scienterque tibiis cantasse. Sed hi erunt fere qui expertes litterarum Graecarum nihil rectum, nisi quod ipsorum moribus conveniat, putabunt. Hi si didicerint non eadem omnibus esse honesta atque turpia, sed omnia maiorum institutis iudicari, non admirabuntur nos in Graiorum virtutibus exponendis mores eorum secutos. Neque enim Cimoni fuit turpe, Atheniensium summo viro, sororem germanam habere in matrimonio, quippe cum cives eius eodem uterentur instituto; at id quidem nostris moribus nefas habetur. Laudi in Creta

\footnotetext{
${ }^{284}$ Geiger $(1985,116)$.
} 
ducitur adulescentulis quam plurimos habuisse amatores. Nulla Lacedaemoni vidua tam est nobilis, quae non ad cenam eat mercede conducta. Magnis in laudibus tota fere fuit Graecia victorem Olympiae citari; in scaenam vero prodire ac populo esse spectaculo nemini in eisdem gentibus fuit turpitudini. Quae omnia apud nos partim infamia, partim humilia atque $\mathrm{ab}$ honestate remota ponuntur.

Contra ea pleraque nostris moribus sunt decora, quae apud illos turpia putantur. Quem enim Romanorum pudet uxorem ducere in convivium? Aut cuius non mater familias primum locum tenet aedium atque in celebritate versatur? Quod multo fit aliter in Graecia; nam neque in convivium adhibetur nisi propinquorum, neque sedet nisi in interiore parte aedium, quae gynaeconitis appellatur, quo nemo accedit nisi propinqua cognatione coniunctus.

Sed hic plura persequi cum magnitudo voluminis prohibet, tum festinatio ut ea explicem quae exorsus sum. Qua re ad propositum veniemus et in hoc exponemus libro de vita excellentium imperatorum.

Não duvido, Ático, que haverá muitos que julgarão leve este gênero de escrita e não suficientemente digno do caráter dos homens ilustres, quando lerem o relato sobre quem ensinou música a Epaminondas, ou quando for lembrado que, entre suas virtudes, ele dançava bem e tocava habilmente flauta.2. Mas esses serão quase sempre aqueles faltos das letras gregas, que nada consideram de bom, a não ser o que convém a seus costumes. 3. Estes, se apreenderem que as mesmas coisas não são honestas e torpes para todos, mas que tudo é julgado segundo os usos dos antepassados, não admirarão que ao expormos as virtudes dos gregos seguimos os costumes destes. 4. De fato, não foi torpe a Címon, célebre herói dos atenienses, casar-se com a irmã, visto que seus concidadãos fazem uso do mesmo costume. Em Creta, para os adolescentes, ter tido o maior número de amantes é que leva ao louvor. Nenhuma viúva lacedemônia é tão nobre que, levada pela recompensa, não vá ter com o amante. E isso certamente é considerado impiedade pelos nossos costumes. 5. Em grandes panegíricos, ser proclamado vencedor de uma Olimpíada foi grande glória em quase toda Grécia; até apresentar-se em cena e dar-se como espetáculo ao povo não foi vergonha para ninguém entre os gregos. Todas essas coisas, entre nós, são consideradas em parte como infames, em parte como humilhantes e distantes do decoro. 6. Ao contrário, a maioria das coisas que são decorosas para os nossos hábitos, para eles são considerados torpes. A quem, entre os romanos, envergonha casar-se durante um banquete? Ou que mãe de família não ocupa o lugar mais importante da casa e não se ocupa com sua reputação? 7. Tudo isso acontece de forma muito diferente na Grécia. De fato, a mulher só é convidada a banquete de parentes, e só fica na parte interior das casas que é denominada gineceu, aonde ninguém vai, a não ser os parentes de sangue. 8. Mas impedem expor mais coisas, de um lado, a grandeza da obra, e de outro, a pressa para explicar o que já comecei. Por isso voltaremos ao nosso objetivo e narraremos neste livro a vida dos chefes eminentes ${ }^{285}$.

Após falar sobre o seu gênero de escrita, que talvez considerado não digno de homens grandiosos, e que contemplaria questões biográficas, como quem ensinou a música a Epaminondas, Nepos adverte o leitor para não julgar os costumes estrangeiros a partir da visão romana, a criar certo distanciamento. Fica claro o interesse por acontecimentos e costumes do não romano e muitas vezes do inimigo, como Aníbal. Stadter ${ }^{286}$, afirma que Nepos com suas Vidas respondeu à necessidade de acesso conveniente à informação geral;

\footnotetext{
${ }^{285}$ Nep., Prefácio. Tradução de R. Ambrosio, In: Ambrosio $(2005,74)$.

${ }^{286}$ Stadter $(2003,533)$.
} 
sua obra teria a função de consulta casual. Os costumes estrangeiros saciariam assim a curiosidade dos ignorantes. Rolfe ${ }^{287}$, afirma que as vidas era endereçadas a um público geral e seu propósito era entreter e apontar uma moral. Lord ${ }^{288}$, defende em seu artigo que os interesses de Nepos são os costumes estrangeiros, a comparação moral entre o passado e o presente, arqueologia.

Mas Nepos também parece construir bioi por considerar deleitável conhecer a vida dos homens ilustres: ao falar dos escritos de Ático, diz que não há nada mais dulce para aqueles que tem desejo de conhecer os homens famosos ${ }^{289}$. E Millar ${ }^{290}$ lembra que Nepos, ao escrever vitas, estava também seguindo um costume da época, inserindo sua obra, assim como a de seu contemporâneo Varrão, em um contexto de produção de obras de antiquário e das grandes coleções de bustos e imagens de homens valorosos do passado, monumentos que perpetuam a memória de exemplos virtuosos.

Mas até que ponto os costumes e os valores estrangeiros aparecem na obra apenas como informação ou deleite, e até que ponto poderiam funcionar como exempla, ou de que maneira são críticas de Nepos aos seus contemporâneos?

Com relação aos costumes, podemos considerar que o mesmo distanciamento solicitado pelo autor pra julgar um costume grego é também o distanciamento que expõe ao leitor que em Roma a situação é diferente. Tal advertência é repetida no início da Vida de Epaminondas, quando Nepos deixa explícita a diferença de opinião romana e grega sobre a dança por parte dos homens. Nepos parece assim não estar sugerindo que costumes estrangeiros sejam seguidos. Mas era sim função da biografia antiga fornecer exemplos de conduta e moral. Como vimos, fornecer exemplo já era inclusive tarefa da história, que dirá pois da biografia, que tem um indivíduo em foco. Plutarco assim afirma na vida de Emílio Paulo:

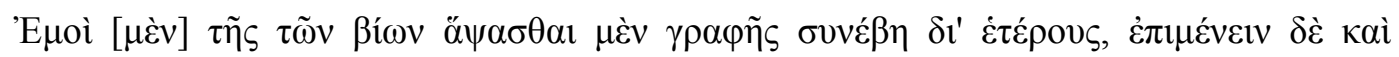

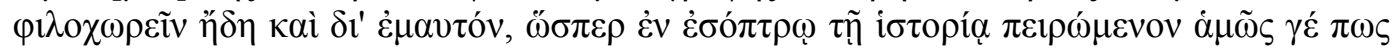

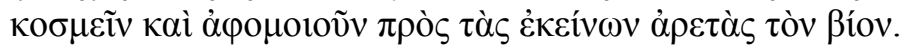

Comecei a escrever biografias para agradar aos outros; depois passei a gostar do gênero e continuei a cultivá-lo para meu prazer, sendo a história para mim como um espelho,

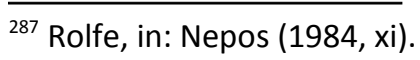

${ }^{288} \operatorname{Lord}(1927,501)$.

${ }^{289}$ Nep. Att. 18.4 (tradução nossa) "Quibus libris nihil potest esse dulcius ii qui aliquam cupiditatem habent notitiae clarorum virorum".

${ }^{290}$ Millar $(1988,50)$.
} 
diante do qual eu tentava tornar minha vida perfeita, amoldando-a aos grandes exemplos $^{291}$.

Plutarco aponta que os grandes exemplos levavam ao seu aperfeiçoamento moral, funcionavam como uma imagem, a ser comparada como num espelho e imitada. A biografia é assim na visão de Plutarco um parâmetro de virtudes a serem imitadas. E tais exemplos Plutarco fornece na escrita da bios, mas também os adquire através da história. É importante salientar aqui que Plutarco não está referindo-se à sua escrita como historía ${ }^{292}$. Ele se ocupa da historía para escrever bioi, descrições de caráter. Tanto história quanto biografia buscam a fornecer exemplos virtuosos ou viciosos, mas na biografia o êthos do biografado está em maior evidência, e talvez a preocupação com o fornecimentos de exemplos seja assim maior. Titchener ${ }^{293}$, a partir deste trecho de Plutarco e de outros texto de Nepos que já citamos, afirma que na biografia antiga a matéria é iluminada para prover um exemplo para o leitor. Nepos, no fim do livro, sugere que o leitor, tendo lido sua obra, estará apto para comparar os comandantes romanos com os estrangeiros:

Sed nos tempus est huius libri facerem finem et romanorum explicare imperatores, quo facilius, collatis utrorumque factis, qui viri praeferendi sint possit iuducari.

Mas nos é chegado o momento de finalizar este livro e narrar a vida dos comandantes romanos, para que, comparando os feitos de uns e outros, mais facilmente se julgue quais homens devem ser colocados em primeiro lugar ${ }^{294}$.

$\mathrm{O}$ autor parece ter por objetivo relatar as vidas e assim dispor aos (e)leitores elementos para que ele mesmo julgue quais homens são mais virtuosos. Parece-nos clara a proposta de comparação de si com o outro na leitura das vidas, como no espelho de Plutarco, só que nos caso uma identificação por oposição com o estrangeiro, mas nem sempre oposição, pois muitas vezes aquilo que é exaltado por Nepos nos estrangeiros é justamente aquilo que é ou deveria ser valorizado pelos romanos. São constantes os elogios dos generais estrangeiros, senão até predominantes.

Dionisotti, em "Nepos and the Generals", através da análise da trechos da obra, e de algumas vidas como um todo, verifica que algumas virtudes valorizadas por Nepos, bem como vícios criticados, são preocupações, do autor com relação à sua própria época, de

\footnotetext{
${ }^{291}$ Plu. Aem. 1.1. Tradução Mario da G. Kury, extraída do Prefácio da Edição PLUTARCO, As vidas comparadas dos maiores guerreiros da Antiguidade: Alexandre e César. São Paulo: Ediouro, 2001.

${ }^{292}$ Cf. Magalhães (2009, 183).

${ }^{293}$ Titchener $(2003,88)$.

${ }^{294}$ Nep. Han. 13 (tradução nossa).
} 
revolta e guerra civil. Na vida de Agesilau, depois de exaltar sua e pietas e obediência à autoridades, Nepos exclama: “Cuius exemplum utinam imperatores nostri sequi voluissent / Oxalá nossos líderes tivessem desejado seguir seu exemplo!" ${ }^{295}$. Dionisotti afirma que não se trata apenas de uma moralização geral, mas que trechos como este comentam o comportamento político, com ponte para os eventos recentes, implicando uma visão específica do que aconteceu de maneira errada ${ }^{296}$. O estudiosos aponta que um valor central na obra de Nepos é a libertas, elogiada e defendida principalmente nas vidas de Trasíbulo e Timoleão. No início da vida de Trasíbulo, Nepos louva o fato do ateniense, quem ele considera o melhor em lealdade, determinação, generosidade de espírito e patriotismo, ter libertado sua pátria da opressão de trinta tiranos, e tê-la libertado da escravidão para a liberdade. E no início da biografia de Timoleão, Nepos engrandece a capacidade do comandante ter libertado Corinto da opressão de um tirano, e também ter libertado os siracusanos da escravidão. A biografia de Timoleão constitui um louvor da libertas. Dionisotti considera esta abordagem que Nepos faz de Trasíbulo e de Timoleão muito indicativa e relevante, já que por outros autores antigos os comandantes não foram considerados por este ângulo.

Dionisotti aponta ainda que o tema da obediência e submissão às autoridades legítimas e à vontade do povo é com recorrência analisado por Nepos nas ações dos biografados. Obediência como uma forma de piedade é observada nos elogiados por Nepos, ao passo que nos vilões, como Pausânias, Lisandro e Fócio, é destacada a desobediência (Cf. Phoc. 4.1). Assim, Dionisotti demonstra que Nepos parece não ver com bons olhos formas de individualismo na vida pública, como um exército particular (Con. 5.1). Em diversos momentos se sobressai também uma crítica à corrupção do povo e à largitio dos lideres ou do Estado (Ham. 3.2; Milt. 6.1).

Parece-nos que Nepos não está reproduzindo inconscientemente as informações encontradas em suas fontes, pois muitas vezes as fontes são questionadas. Tais reflexões parecem-nos pertinentes no período da era de César e dos Triunviratos. Outro acontecimento recorrente nas vidas dos generais é destino triste do general, quase sempre "injusto", aparentemente resultado da ingratidão da própria pátria. Milcíades é acusado de traição em um combate e é condenado à prisão, onde morre pouco depois. Datâmes é morto em uma armadilha assim que começou a ser considerado uma ameaça ao rei. Alcibíades e Timóteo são condenados. Temístocles, Aristídes, Címon e Aníbal, exilados. Fócio, indo sofrer sua pena, diz que a iniquidade que está sofrendo não era inesperada, pois este havia sido o final da ${ }^{295}$ Nep. Ages. 4.3. (tradução nossa)
${ }^{296}$ Dionisotti $(1988,39)$. 
maioria das pessoas ilustres em Atenas (Phoc. 4.3). E Nepos afirma que o motivou tais penas foi sempre o medo da tirania e do poder destes generais. Expondo o real motivo da condenação de Milcíades, Nepos escreve que, apesar do general ter sido irrepreensível em sua carreira, e nunca parecer ser uma ameaça de tirania, por causa de suas virtudes, grande fama como soldado e por possuir influência nos estados gregos, o povo preferiu que, embora inocente, Milcíades deveria sofrer, a continuarem a temê-10 ${ }^{297}$.

Temístocles é vítima da inveja de seus próprios concidadãos (Them. 8.1), Alcibíades é suspeito de lutar mais por interesses particulares que do Estado (Alc.. 3.3), Timóteo é condenado pelo povo ateniense, que Nepos qualifica de invejoso (Timoth. 3.5). Dionisotti defende que Nepos, através de tais acontecimentos, está problematizando a relação entre poder militar e política. O biógrafo demonstra como tais figuras ilustres representaram ameaças à democracia grega, ou a outras formas de governo democráticas. E tal discussão, o conflito entre o poder de um e a vontade pública, parece-nos bastante pertinente à reflexão que devia ser corrente no período contemporâneo a Nepos, em que eram vistos sinais do fim do regime republicano. Dionisotti assim conclui:

The issue that Nepos' imperatores raise, again and again, is the relationship between military success and political control. The careers of Datames and Eumenes illustrate the precarious existence and ultimate impotence of generals subject to a monarch. But how can a state that is not a monarchy cope with the power that inevitably accrues to a successful military leader? Nepos was surely right to see this as a central problem when he wrote. His exploration of Greek history in this light might not offer any practical solutions, history rarely does; explaining ostracism to the Romans was not to suggest that they either could or should institute it. But I think Nepos' effort to understand the problem is both interesting and worthy of respect. Of course the younger generation, Virgil now writing his Eclogues, Horace his Epodes and Satires, saw the problems differently. Nepos could not, like Tityrus, imagine that libertas was something bestowed by a divine young man in Rome ${ }^{298}$.

Nepos demonstra em suas Vidas como os generais passaram de heróis a ameaças à democracia, já que são acusados, mesmo que injustamente, pelo povo que temia a tirania. Vendo por tal ângulo, Nepos torna-se um biógrafo que avalia o seu tempo, o bom e o mau comportamento no contexto político, procura assim exemplos anteriores em povos estrangeiros e tenta considerar os efeitos de tais condutas. O autor coloca em discussão a incompatibilidade entre liberdade, respeito ao povo, e poder e fama dos comandantes. Fica claro que, na visão do autor, ter poder é algo muito perigoso. Essa não conciliação parece ser

\footnotetext{
${ }^{297}$ Nep. Milt. I.8.3-4.

${ }^{298}$ Dionisotti $(1988,49)$.
} 
a visão defendida predominantemente por Nepos na obra, mas em alguns momentos a posição do autor não nos parece tão bem definida, como quando Nepos reconhece que Aníbal, mesmo sendo um general com exército, foi um bom governante para Cartago durante o período de um ano. A Vida de Aníbal inicia-se com um grande elogio da habilidade militar do general e de suas vitórias em solo itálico. Mas logo depois já está apontado o conflito entre Aníbal e seu poderio e a sua nação: "E se não tivesse sido enfraquecido pela inveja de seus compatriotas, aparentemente poderia ter derrotado os romanos. Mas o ódio de muitos prevaleceu sobre a virtude de um” (Han. 1.1). Em 7.1, está indicada a ameaça que Aníbal representava aos romanos ao permanecer com seu exército, aparentemente em uma iniciativa privada, mesmo após o acordo após a derrota cartaginesa. Entretanto, Nepos elogia o governo político de Aníbal:

Quando Aníbal aplicava-se mais intensamente a estes preparativos, os cartagineses firmaram a paz com os romanos. Ele, mesmo depois disso, não deixou de presidir o exército; dirigiu a guerra na África até o consulado de Públio Sulpício e Gaio Aurélio. E eis que, durante tais magistraturas, embaixadores cartagineses vieram a Roma a fim de agradecer ao Senado e ao povo pela paz firmada e, em gratidão, ofereceram a eles uma coroa de ouro, e pediram o retorno dos prisioneiros, sendo que os reféns permaneceriam em Fregelas. A seguinte resposta, segundo a deliberação do Senado, lhes foi dada: que aceitavam e eram gratos pelo presente; que os reféns viveriam no lugar que solicitaram, mas que os prisioneiros não seriam devolvidos porque Aníbal, que havia sido a causa da guerra empreendida e era o maior inimigo do povo romano, até o presente momento tinha poder junto a seu exército, assim como seu irmão Magão. Tendo tomado conhecimento desta resposta, os cartagineses pediram que Aníbal e Magão retornassem à Cartago. Quando lá chegou, Aníbal, após de ter sido general por vinte e dois anos, foi nomeado rei: assim como se dava com os cônsules em Roma, em Cartago dois reis eram escolhidos a cada ano. No período de sua magistratura, Aníbal valeu-se da mesma diligência de que se valera na guerra. Pois, impondo novos tributos, conseguiu não só o dinheiro para pagar os romanos conforme o acordo de paz, mas também para além desta quantia, repondo assim o tesouro público. Em seguida, no consulado de Marco Cláudio e Lúcio Fúrio, embaixadores romanos vieram a Cartago. Aníbal seguro de que os enviados haviam vindo com o propósito de requerê-lo, antes que o Senado se encontrasse com eles, secretamente subiu em um navio e chegou à Síria, para junto de Antíoco. Quando este feito tornou-se conhecido, os Púnicos enviaram duas naus para apanhá-lo caso conseguissem segui-lo, confiscaram seus bens, destruíram sua casa desde a fundação, e declaram-no, por julgamento, exilado ${ }^{299}$.

Aníbal tinha um exército, era uma ameaça ao senado cartaginês, mas mesmo assim foi um bom líder. Nepos vê como positivo o fato de Aníbal administrar a cidade com a mesma diligência que tinha para com o exército. O biógrafo parece nesse trecho reconhecer que comandantes com poder militar podem sim respeitar a vontade do povo, mas que não é isso que geralmente ocorre. Ao nosso ver, Nepos não está criticando as ditaduras militares de

\footnotetext{
${ }^{299}$ Nep. Han. 7 (tradução nossa). O texto latino pode ser facilmente consultado nos anexos da presente Dissertação.
} 
maneira explícita, mas o faz de maneira indireta apontando que o destino dos generais e figuras que se destacam é frequentemente ruim, pois podem tornar-se, aos olhos do povo e de outros políticos concorrentes, ameaças à república. Nepos reconhece que Aníbal é um bom governante por um dado momento, mas logo depois o destino comum das figuras ilustres também o alcança: o cartaginês será também exilado, por representava uma ameaça ao acordo de paz entre Roma e Cartago. Embora tal conflito não esteja bem resolvido mesmo para Nepos, o autor certamente não imaginava, como afirmou Dionisotti, que a libertas seria concedida justamente por um imperador em Roma.

Outra questão que o destino infeliz da maioria dos grandes generais discute é sobre a ação da Fortuna ${ }^{300}$. Na Vida de Ático, biografia pertencente à obra das vidas dos historiadores latinos, Nepos afirma que Ático é responsável por sua Fortuna, ao dizer que para ele é verdadeiro o ditado "Sui cuique more fingunt fortunam hominibus": "os costumes de cada um moldam a Fortuna dos homens". (Att. 11.6). O biografo destaca que, por sua neutralidade e discrição, Ático conseguiu escapar de acusações em um momento conturbado de disputa pelo poder $(10.6)^{301}$. Para Nepos, Ático não se envolveu na política para continuar a ser dono de sua Fortuna, "pois sabia que aqueles que se envolviam em tais conflitos não eram mais donos do seu destino do que seriam se fossem arrastados pelas tempestades do mar" 302 . Em trecho já citado, o comandante Fócio demonstra que já esperava um destino amargo, pois este era o fim dos que se destacaram. Nepos está alertando então que ser poderoso tem um preço, que a Fortuna na maioria das vezes não é boa para aqueles que se sobressaem; que alguém pode ser herói hoje e amanhã ser acusado de traição por tornar uma possível ameaça à res publica. Como vemos, Nepos parece ressaltar o caráter trágico do fim da vida de alguns generais, o que em certa medida contribui para a caracterização destes generais como heróis trágicos.

\subsection{A Vida de Aníbal}

A Vida de Aníbal não se inicia de maneira cronológica. Após uma introdução na qual Nepos exalta a capacidade militar e as vitórias de Aníbal em solo itálico, e após indicar que a

\footnotetext{
${ }^{300}$ Para um breve estudo do emprego do termo fortuna da obra de Nepos, ver J. D. Jefferis (1943).

${ }^{301}$ Cf. Millar (1988). O estudioso analisa como Ático é elogiado por Nepos por aquilo que não fez, por ter passado ileso pelas tentações da vida pública e pelas mudanças políticas. Ático evitou muitas ações públicas, preservando assim sua dignitas e tranquillitas, e evitando assim suspeitas de crimina.

${ }^{302}$ Nep. Att. 6.1. "In re publica ita est versatus, ut semper optimarum partium et esset et existimaretur, neque tamen se civilibus fluctibus committeret, quod non magiss eos in sua potestate existimabat esse qui se his dedissent, quam qui maritimis iactarentur."
} 
causa da derrota fora a inveja dos seus conterrâneos, Nepos inicia o relato de uma maneira anedótica, relatando uma conversa de Aníbal com o rei Antíoco, estando Aníbal já exilado na Síria, bem depois da Segunda Guerra Púnica. Vejamos o trecho:

Quando os embaixadores romanos vieram até Aníbal [na corte de Antíoco] a fim de investigar seus propósitos, fizeram com que o rei suspeitasse, por causa das conversações secretas, de que Aníbal havia sido corrompido e havia mudado de opinião. Tal artimanha não foi em vão, e Aníbal, tendo descoberto o plano e vendo-se apartado das decisões interiores da corte, foi até o rei em momento oportuno e, recordando muitas palavras sobre sua fidelidade e ódio contra os romanos, disse o seguinte: "Meu pai Amílcar, imperador na Hispânia, após deixar Cartago, imolou sacrifícios a Júpiter Óptimo Máximo quando era eu um menino de não mais que nove anos. Enquanto este sacrifício divino era preparado, perguntou-me se queria ir consigo ao acampamento. Quando de bom grado disse que iria e já começava a pedir-lhe que não hesitasse em levar-me, ele respondeu: "Assim farei se me concederes o juramento que te peço". Naquela instante me conduziu ao altar onde se iniciava o sacrifício e, tendo feito os outros se retirarem, impôs as mãos sobre mim e ordenou-me jurar que eu nunca seria amigo dos romanos. Este juramento, feito a meu pai, guardei até este momento, e ninguém deve duvidar de que não terei mesma índole no futuro. Por esta razão, se conjecturas algo de amizade romana, agirias com prudência se ocultasses a mim; mas, se preparas a guerra contra eles, tu falharás se não me tiver como o primeiro no comando." [3] Com essa idade que mencionamos, Aníbal partiu para a Hispânia com o pai (Nep. Han. 2.2-3.1). ${ }^{303}$

A fonte de Nepos para essa anedota é provavelmente Políbio, ou uma fonte comum aos dois autores, visto a semelhança com a narrativa em que o historiador relata este episódio no qual Aníbal, sob suspeita, teria lembrado seu juramento de ódio aos romanos em uma fala ao rei Antíoco (Plb. 3.11). No texto de Políbio, o episódio aparece como uma evidência suficiente para confirmar que Amílcar teve sua parte na motivação da Segunda Guerra Púnica, como uma maneira de confirmar a hostilidade do pai de Aníbal (Plb. 3.12.1). O historiador discute nessa parte de seu livro terceiro três as causas da Segunda Guerra Púnica, antes do relato dos eventos que dão início ao conflito, como o ataque a Sagunto. O trecho nepotiano é bem parecido com o de Políbio no que se refere aos detalhes, mas em Políbio a fala de Aníbal é mencionada indiretamente. Nepos escolhe iniciar seu relato por esta anedota do fim da vida de Aníbal, uma circunstancia interior à corte de Antíoco, uma conversa pessoal com o rei, algo que seria mais do âmbito anedótico e privado, embora tivesse sido utilizado por Políbio, ainda que como uma forma indireta de apresentar o relato do juramento infantil de Aníbal. Mas ao fazer Aníbal discursar por si, Nepos coloca Aníbal vivo diante dos olhos leitor, que vê um homem de caráter fiel ao seu juramento e a todos. Assim, Nepos faz o próprio Aníbal falar

\footnotetext{
${ }^{303}$ Tradução nossa. Não apresentaremos o texto latino dos trechos citados de Cornélio Nepos uma vez que podem ser consultados nos Anexos.
} 
sobre o juramento que fizera ao seu pai quando criança, e depois então inicia o relato em ordem cronológica das ações de Aníbal a partir da idade em que tinha no juramento, e os acontecimentos da corte de Antíoco serão tratamos somente mais tarde.

Parece claro no início da biografia as ações narradas estão subordinadas à descrição do caráter, pois as ações servem para ilustrar a afirmação, ainda no parágrafo um, de que Aníbal conservou intacto seu ódio e juramento. E são as próprias palavras de Aníbal que relatam o acontecimento anedótico, o juramento, do qual também são descritos detalhes que tornam a cena viva. Por um lado, temos uma relativização do que é narrado uma vez que se trata da voz da personagem, por outro, o detalhamento da descrição produz vivacidade, almejando o efeito de verdade. Em Tito Lívio, o relato o juramento é introduzido com a reserva "fama est" (21.1.4). Fica mais claro, dessa maneira, na história, de que o relato trata-se de uma informação anedótica. Entretanto, na história também são comuns os discursos fictícios, colocados na boca das personagens. Mais uma vez confundem-se neste aspecto limites entre biografia e história.

Os eventos que sucedem a saída de Aníbal e de seu exército da Hispânia em direção a Roma, a passagem pelos Alpes, as pequenas batalhas vencidas e as grandiosas batalhas de Trébia e Trasimeno são sumarizadas pelo autor (Cf. p.163). Nepos apenas cita os eventos em ordem cronológica, sem muitos comentários e detalhes. Comenta, é claro, que a passagem do exército pelos Alpes foi uma proeza, realizada antes somente por Hércules, o que os estudiosos dizem ser um exagero de Nepos.

O famoso episódio da batalha de Canas, considerada a maior derrota romana, é descrito apenas pelas seguintes palavras: "Em seguida chegou à Apúlia. Ali vieram ao seu encontro dois cônsules, Gaio Terêncio e Lúcio Emílio. Em uma única batalha Aníbal pôs em fuga os exércitos de ambos, matou o cônsul Paulo, além de outros consulares, entre os quais Gneo Servílio Gemino, que havia sido cônsul no ano anterior.” A batalha de Canas, que seria talvez o maior exemplo da capacidade estratégica militar de Aníbal, pois nela o general venceu o exército romano que estava em muito maior número, é descrita pela tradição historiográfica como um desastre romano, como vimos na narrativa de Lívio, por exemplo, uma vez que os romanos, cercados, foram massacrados sem a possibilidade de bater em retirada. Talvez por esse motivo um maior detalhamento da batalha fique de fora da biografia de Nepos, pois é provável que o episódio seja para a recepção do livro, romana, memorável como demasiado cruel, e parece-nos que Nepos quer construir um retrato virtuoso do general, como veremos. 
E nada se comenta sobre a demora de Aníbal em marchar em direção a Roma, o que é considerado pelos historiadores como o erro de estratégia que impediu Aníbal de vencer a guerra. Diferentemente do que ocorre na história, não há aqui uma análise apurada das causas das derrotas e das vitórias. Nepos, de uma maneira geral, aponta somente como causa da derrota de Aníbal a inveja de seus concidadãos, logo no início da biografia. Nepos exclui a reflexão corrente na historiografia sobre a demora de Aníbal em marchar até Roma, e, pelo contrário, através de seu relato parece que a demora não existiu, quando o autor inicia no parágrafo seguinte desta maneira: "Vencida esta batalha, avançou em direção a Roma sem nenhuma resistência, e acampou nos montes próximos à cidade”. Da mesma maneira, Nepos não problematiza a estadia de Aníbal em Cápua, apenas sucintamente mencionada.

Mas, em seguida, Nepos, no parágrafo 5, relata com bastantes detalhes a artimanha que Aníbal, cercado por um desfiladeiro, utilizou para despistar o cônsul Fábio Máximo. A artimanha de atear fogo aos chifres de novilhos durante a noite causando horror nos romanos é descrita com maior atenção por Nepos que a própria batalha de Canas. E em seguida Nepos afirma que Aníbal venceu o cônsul Tibério Semprônio Graco e Marco Cláudio Marcelo também com estratégia e emboscadas (Cf. p.164).

Nepos assim resume os acontecimentos em solo itálico antes do retorno de Aníbal à África, onde só encontraria a derrota: "Seria uma tarefa longa enumerar todas as batalhas.. Será suficiente relatar um único fato sobre elas, a partir do qual se poderá compreender o valor deste homem: enquanto esteve na Itália, ninguém pode resistir a ele em batalha, e após Canas, ninguém se arriscou a montar acampamento em campo a sua frente” (Han.5.4).

No parágrafo 6, Nepos parece exagerar ao dizer que Aníbal retornou invicto a Cartago para defender sua pátria. Segundo Lívio, como vimos, Aníbal teria sofrido sim algumas derrotas em solo itálico: foi, por exemplo, derrotado por Marcelo em Nola (Liv. 23.44-45). Políbio em suas histórias também considera Aníbal como invencível até Zama, e tal elisão é criticada depois por Plutarco na Vida de Marcelo.

A derrota de Aníbal em Zama é mencionada mais resumidamente ainda, e a narrativa enfatiza logo a capacidade de Aníbal de ter fugido tão rapidamente e chegado a Adrumeto (Cf. p.165).

Assim, parece-nos que os detalhes das ações do general só interessam a Nepos quando deles pode-se depreender o caráter que biógrafo quer construir: o do grande estrategista. Até então, em detalhes só pudemos ver o feito em que Aníbal despista Fábio com a artimanha de atear fogo nos chifres de bois. No fim da biografia, como veremos, a batalha contra o rei 
Eumenes, vencida com uma estratégia singular, também será descrita em detalhes. Nepos em momento algum sugere que Aníbal possa ter errado em alguma estratégia e decisão, como faz Lívio quando fala sobre a demora após Canas, sobre a estadia em Cápua e a pilhagem de territórios de antigos aliados. E também não há menção à episódios relatados pela tradição historiográfica analística que evidenciam vícios como avareza, perfídia e crueldade. Embora Políbio pareça ter sido uma fonte para a biografia, nada é mencionado sobre o vício do amor excessivo pelo dinheiro atestado nas Histórias (Plb. 9.25.1).

Assim, a narrativa parece ignorar os acontecimentos famosos, normalmente presentes nos historiadores latinos, como vimos, que o retratariam com os vícios tradicionalmente associados ao general. Segundo Loius E. Lord ${ }^{304}$, Nepos utilizou como fonte para a biografia provavelmente Políbio, talvez seu amigo Ático, além dos historiadores, dos quais pouco sabemos, que o próprio autor menciona na discussão sobre que consulado teria se dado a morte de Aníbal: Sulpício Blito, Sileno e Sósilo. Nepos pode ter tido sim fontes mais afeiçoadas a Aníbal, como Sileno, o que poderia justificar o retrato virtuoso de Aníbal, mas é difícil imaginar que ele desconhecesse os relatos negativos acerca do general, que parece ter sido a tradição predominante. Nepos parece ter tido acesso a Políbio, que discute a fama dos vícios de Aníbal (9.24-26). Assim, Nepos parece fazer uma seleção consciente do material para construir o êthos que deseja.

Mas analisemos a segunda parte da biografia, que se dedica aos acontecimentos após o acordo de paz com os romanos. Nepos relata que Aníbal continuou a intencionar a guerra, e descreve no parágrafo 7 como exerceu diligentemente a magistratura de rei em Cartago, dizendo que "No período de sua magistratura, Aníbal valeu-se da mesma diligência de que se valera na guerra. Pois, impondo novos tributos, conseguiu não só o dinheiro para pagar os romanos conforme o acordo de paz, mas também além desta quantia, repondo assim o tesouro público". Tito Lívio, entretanto, afirma, pelo contrário, que quando Aníbal era pretor faltara dinheiro para pagar o tributo devido aos romanos (33.46).

No parágrafo oitavo, Nepos sumariza os feitos de Aníbal junto do rei Antíoco, e neste relato sobressai a vontade incessante de Aníbal guerrear contra os romanos, e sua experiência e capacidade militar é elogiada quando o biógrafo aponta que Antíoco não seguiu o conselho de Aníbal de não guerrear em Termópilas (Cf. pp.166-7). Nepos faz questão de ressalvar que Aníbal venceu com o flanco que comandou na batalha naval contra os ródios. Tal narrativa

${ }^{304}$ Lord $(1927,499)$. 
contrasta com a posterior de Tito Lívio, que, descreve o flanco de Aníbal em retirada (Liv. 37.24).

Nos parágrafos 9 a 11, Nepos descreve com detalhes dois episódios importantes para pintar o caráter de Aníbal como astucioso: sua passagem por Creta e a batalha naval de Prúsias contra Eumenes. Após o acordo de paz de Antíoco com os romanos, Aníbal foge para Bitínia, passando, segundo Nepos, por Creta, onde despistou os cretenses que estavam de olho em sua fortuna. A anedota funciona como uma illustratio de sua astúcia:

Entretanto, o homem mais astuto de todos percebeu que estaria em grande perigo se não se precavesse contra a cobiça dos cretenses, pois carregava consigo grande quantidade de dinheiro, da qual sabia que havia boatos. Então realizou o seguinte plano: encheu várias ânforas com chumbo, e cobriu a superfície delas com ouro e prata. Entregou as ânforas no templo de Diana, na presença dos principais homens da cidade, simulando assim que entregava sua fortuna em lealdade a eles. Depois de ter enganado a todos, encheu com todo seu dinheiro algumas estátuas de bronze que levava consigo as colocou no pátio de sua casa. Os Gortinos guardavam o templo com grande cuidado, não por outros, mas por causa de Aníbal, para que esse não retomasse e levasse consigo nada sem que soubessem ${ }^{305}$.

Interessante que, na visão da biografia, são os cretenses, e não Aníbal, que tem o vício da cobiça. A anedota parece apenas louvar o fato de Aníbal, callidissimus, ter enganado a todos, e não parece questionar o apego de Aníbal à sua riqueza, embora também o evidencie. Se há também uma crítica à avareza de Aníbal, ela é sutil, pois o foco da anedota é a astúcia do general frente à avareza dos cretenses. E em nenhum outro momento da narrativa há menção a tal vício de Aníbal.

De maneira mais detalhada ainda, construindo uma verdadeira écfrase, Nepos narra o episódio em que Aníbal, ao lado do rei Prúsias, vence a batalha naval contra o rei Eumenes com uma estratégia incomum, usando cobras como armas. O relato ocupa dois parágrafos, uma grande extensão se pensarmos que a vida toda tem somente treze (Cf. pp.167-8). Nepos descreve vivamente as ordens de Aníbal aos soldados na preparação da artimanha, o artifício para descobrir em qual navio inimigo estava o rei, a batalha em si e o pânico dos inimigos diante do navio tomado pelas serpentes venenosas que caiam dos vasos atirados pelo lado de Aníbal. E assim o biógrafo conclui o episódio: "Desta maneira, Aníbal superou pela astúcia (consilio) as armas dos pergamenos: e não somente neste caso, mas em muitas outras vezes afastou os inimigos em batalhas terrestres com igual inteligência [prudentia] (Nep. Han.11)".

A batalha naval contra Eumenes, que não referida nem por Políbio, Tito Lívio, nem Apiano, aparece pela primeira vez em Nepos, segundo temos conhecimento. Nepos inclui, desta maneira, um episódio pouco comum na tradição historiográfica, pelo menos nos autores ${ }^{305}$ Nep. Han., 9. (Tradução nossa). 
que nos restaram, e dá a ele considerável atenção, uma vez que contribui para a confirmação de um caráter astucioso. Sabemos, através de epitome feito por Justino, no séc. II d.C, que Pompeu Trogo, historiador do século I. a.C., também relatou este episódio, embora não seja possível precisar se sua fonte foi Nepos, ou uma fonte comum. O episódio em Creta é também relatado no epitome (Justino, 32).

No parágrafo 12, Nepos relata a ocasião da morte de Aníbal. Não encontramos em nenhuma outra narrativa o relato sobre o jantar em que Flamínio descobre sobre o paradeiro de Aníbal através de um embaixador. Nos historiadores e em Plutarco, Flamínio descobre o fato estando já na Bitínia, tendo sido enviado por outros motivos (Plu. Flam., 20,5, App, Syr. 43, Liv. 39.51.1-2). Lívio considera a possibilidade de Prúsias tê-lo entregue para firmar algum acordo com e Roma. Mais uma vez Nepos parece preferir uma versão com informações mais do âmbito privado, provavelmente um boato sobre como Aníbal teria sido descoberto.

A descrição da morte do general por Nepos, o suicídio diante da iminência de ser preso, são descritos com detalhes vívidos. Nepos cria uma conversação de Aníbal com um escravo enquanto analisavam o cerco que os romanos faziam em sua casa, mais uma vez uma conversação entre quatro paredes (Cf. p.169). Tal conversação parece-nos recordar a primeira conversa de Aníbal com Antíoco, e assim Nepos inicia e termina a biografia com acontecimentos de caráter mais privado que público. Ao contrário do que ocorre em Lívio, Aníbal, na narrativa de Nepos, não amaldiçoa Prúsias por ter quebrado as regras de hospitalidade. O biógrafo apenas diz sobre a decisão de Aníbal suicidar-se: "Não querendo entregá-la à decisão de outro, recordando-se de seus feitos virtuosos do passado, tomou o veneno que costumava sempre levar consigo" (Han.12). Seu suicídio parece-nos, portanto, descrito por Nepos também como uma forma de estratégia, um meio de escapar da submissão aos romanos. A narrativa desse episódio, muito mais patética em Lívio, como vimos, aqui apenas evidencia novamente sua astúcia. Aliás em toda a biografia, Aníbal em momento algum é descrito agindo tomado de páthos, apenas seu ódio aos romanos é mencionado do início da vida e depreendido de seu discurso ao rei Antíoco. Assim, seu caráter é de um general racional em todos os momentos. A narrativa da morte do general tampouco discute a indignidade da ação romana e a infidelidade do rei Prúsias; ao contrário, Nepos isenta Prúsias da culpa, dizendo que eles não aceitou que pedissem que fosse feito por ele algo que era contra as regras da hospitalidade, que os próprios romanos deviam procurar por Aníbal sozinhos. Nepos, assim, não termina o retrato de Aníbal como traído e enganado, pois, em toda a vida, é ele o callidissimus general. 
A astúcia de Aníbal, tradicionalmente associada à perfídia, não parece ser considerada como tal pelo biógrafo. Alguém poderia defender que Nepos estaria sendo irônico, e ler sua inteligência como perfídia, argumentando que o destino final do general, o exílio, fora ruim, ou que essa não era uma virtude romana republicana, e com isso Nepos estaria estabelecendo um contraste entre romanos e estrangeiros. Mas tal leitura dificilmente pode ser compatível com o parágrafo inicial da biografia, que já direciona a leitura do resto da vida como laudatória: "Aníbal, cartaginês, filho de Amílcar. Se é verdade - o que ninguém duvida - que a nação romana superou todos os povos em virtude, não se deve negar que Aníbal precedeu todos os outros comandantes em habilidade militar, assim como o povo romano todas as nações em força. Pois todas as vezes que lutou contra romanos em solo itálico, saiu vitorioso. E se não tivesse sido enfraquecido pela inveja de seus compatriotas, aparentemente poderia tê-los derrotado. Mas o ódio de muitos prevaleceu sobre a virtude de um”. (Nep. Han. 1). O trecho convida a ver Aníbal como o melhor em estratégia militar (prudentia), assim como Roma fora a nação mais virtuosa. E em seguida afirma que inveja e ódio dos seus conterrâneos prevaleceu sobre a virtude (virtutem), de um, Aníbal. Parece, claro, assim, que a inteligência militar é louvada pelo biógrafo, e não depreciada como perfídia.

O parágrafo conclusão da biografia é também bastante laudatório (Cf. pp.169-70). Nepos afirma que Aníbal, a quem ele se refere como fortissumus, morreu aos setenta anos de idade. Nepos ressalta que o general, que se dedicou tanto tempo à guerra, aplicou-se também às letras gregas no fim da vida. Nepos é a única fonte sobre tal informação. $\mathrm{O}$ caráter de Aníbal, escapa, assim, definitivamente, ao estereótipo de estrangeiro como bárbaro. Aníbal não é apenas força, mas principalmente intelecto. Aliás, na comparação entre Roma e o general do primeiro parágrafo, Aníbal supera a todos em estratégia e Roma em força (fortitudine).

Interessante notar que não há na biografia caracterização física de Aníbal. Melina Rodolpho, em estudo do tratado de fisionomia latino ${ }^{306}$, destaca que as associações entre atributos do caráter e a aparência física são exemplificadas em maioria por associações de vícios e características físicas. Suetônio, Salústio e Júlio César normalmente fazem a descrição física de alguém quando o retrato é negativo. São mais raras as descrições físicas quando o caráter é virtuoso. Podemos imaginar então que, como Nepos louva Aníbal, não há então descrição física.

${ }^{306}$ Rodolpho (2012). 
Podemos ver que a narrativa, do início ao fim, organiza-se através de uma seleção de fatos virtuosos do Aníbal, e de maneira a ressaltar acontecimentos em que se destaca a estratégia de Aníbal. Ao falar do ano da morte do general, Nepos aponta várias divergências entre as versões de sua fonte, discussão essa que não foi feita em nenhum momento anteriormente com relação aos outros acontecimentos. Tal estratégia cria a impressão de que há consenso entre tais historiadores sobre as ações anteriormente relatadas, o que coopera para a persuasão. Das fontes citadas na conclusão, só conhecemos Políbio. Entretanto, é o suficiente para observarmos que Nepos seleciona do historiador apenas os acontecimentos relevantes para o retrato que quer construir, e modifica a percepção de alguns acontecimentos, pois, como já comentamos no capítulo sobre o êthos de Aníbal em Tito Lívio, Políbio em sua menciona sim vícios do general, embora não de maneira tão hostil como outros autores.

A seleção do material feita por Nepos inclui também alguns detalhes biográficos, e algumas vezes episódios anedóticos, com detalhes verossímeis, na tentativa de conferir vivacidade e acrescentar elementos da esfera "privada" ao relato político e militar de Aníbal, além de que a descrição de algumas ações, como a batalha contra o rei Eumenes, funciona como ilustração da astúcia do cartaginês. Como vimos, o biógrafo é seletivo; importam somente os feitos pertinentes para que se conheça a natureza do biografado, ou melhor, para o retrato do caráter que o biógrafo quer pintar; a seleção das ações é que está a serviço do êthos, do astucioso, no caso. O historiador, ao contrário, como afirmou Momigliano, tem a obrigação de não ser seletivo, embora saibamos que ele também o é em menor escala, e que também rearranja os acontecimentos de maneira a criar um dado retrato. Mas isso é feito geralmente relativizando-se acontecimentos ou amplificando outros, e não de maneira explícita como Nepos faz na biografia.

Mas qual seria o propósito de Nepos ao louvar Aníbal, e criar assim uma homenagem e monumento à vida de um inimigo? O retrato criado pelo biógrafo parece colocar-se contra tradição historiográfica analística, que, como já dissemos, era, em maioria, hostil a Aníbal. Estaria Nepos tentando ver além da tradição historiográfica? Difícil precisar. Podemos apenas conjecturar algumas suposições a partir das poucas indicações que temos sobre o intuito de Nepos com sua obra.

Como já dissemos, no fim da Vida de Aníbal, Nepos anuncia o fim da obra e o início da série sobre a vidas dos generais romanos, e sugerindo a comparação entre romanos e estrangeiros. Nepos estaria então fornecendo o material para que o leitor julgue, através dos feitos dos estrangeiros e dos romanos, quais foram mais valorosos no passado. Como apenas 
nos restou uma pequena parte da obra, a sumária Vida de Catão, e a Vida de Ático, não podemos fazer hoje tal comparação. A biografia de Catão, entretanto, é bastante laudatória. Dentro deste esquema de se escolher o melhor, a imagem virtuosa de Aníbal, a exaltação de sua estratégia militar, louva o estrangeiro, mas também aqueles que foram capazes de superálo e vencê-lo, como Cipião Africano. Não sabemos se haveria uma vida sobre Cipião no livro dos estrangeiros. De qualquer maneira, Nepos parece propor a discussão sobre a virtude da astúcia com a vida de Aníbal; apresenta tal qualidade como laudatória aos romanos, mais simpatizados com a vitória pela força física. Nepos estaria assim discutindo valores de sua sociedade olhando para os costumes estrangeiros.

Considerando as ideias de Dionisotti que já tratamos no tópico anterior, principalmente sua análise do destino trágico dos generais na obra de Nepos e a incompatibilidade entre poder militar e político, vimos que a biografia de Aníbal também discutia tais relações. Nepos reconhece que Aníbal foi bom governante durante sua magistratura por um dado momento, mas logo depois o destino comum das figuras ilustres também o alcança: o cartaginês será também exilado, por representar uma ameaça ao acordo de paz entre Roma e Cartago. Nepos também na Vida de Aníbal demonstra que ser poderoso tem um preço, que a fortuna na maioria das vezes não é boa para aqueles que se sobressaem; que alguém pode ser herói hoje e amanhã ser acusado de traição por tornar uma possível ameaça à res publica. Neste esquema, é necessário que o retrato de Aníbal seja laudatório, pois se seu caráter fosse vicioso, seu fim, o desterro e sepultamento fora da pátria, não seria injusto e incompatível com sua grandeza.

Por fim, o retrato laudatório, e, de certa maneira tipificado (o estrategista), enquadrado em uma série de retratos, poderia ser comparada a uma coleção de bustos de figuras ilustres. Como já dissemos, Millar ${ }^{307}$ lembra que Nepos, ao escrever vitas, estava também seguindo um costume da época, inserindo sua obra, assim como faz também Varrão, em um contexto de produção de obras de antiquário e das grandes coleções de bustos e imagens de homens valorosos do passado, monumentos que perpetuam a memória de exemplos virtuosos. Segundo Paulo Martins, um dos modelos de estátua típicos da República é aquele que explora a condição pública do figurado de acordo com sua condição política ou religiosa" ${ }^{308}$. Duas vertentes de figuração parecem ter norteado a produção de imagens plásticas em Roma: uma cujo fundamento está assentado na marca serial helênica e indica por meio de alguns detalhes

\footnotetext{
${ }^{307}$ Millar $(1988,50)$.

${ }^{308}$ Martins $(2011,59)$.
} 
a pertença a um determinado grupo (o sábio, o atleta), e outra do retrato de molde, fisiognômico, ou verista ${ }^{309}$. A última vertente é associada ás estátuas de caráter privado, utilizadas nos cultos da memória dos antepassados, que eram construídas a partir de máscaras mortuárias, e que expunham assim imperfeições impressas a partir do molde real. O Aníbal de Nepos é o Aníbal general, o estrategista, sua imagem pública. Embora a biografia fosse o gênero adequado para conhecer se conhecesse detalhes da vida particular e afetiva, não é o que ocorre em $\mathrm{Nepos}^{310}$. A matéria é político e militar, subordinada, é claro, ao caráter, e selecionada de maneira diferente daquela da historiografia. A imagem construída por Nepos é uma imago plastificada, moldada a ponto de esconder as imperfeições do caráter e amplificar a sua virtude militar. Podemos compará-la às imagines republicanas públicas, pertencente à primeira versão de retratação mencionada acima. Nepos constrói uma imagem que abstrai do Aníbal da tradição historiográfica, na maior parte das vezes ambíguo entre vícios e virtudes, apenas uma parte, pública e virtuosa, criando desta maneira um busto militar, afinal, a série de vidas é de generais. A imagem de Aníbal constitui-se, assim, como um monumento público, que exalta a estratégia militar, e funcionaria assim como um exemplo aos romanos, imaginando que Nepos talvez, com isso, visasse uma revisão dos valores de sua pátria. $\mathrm{O}$ olhar para o outro, entretanto, também pode ressaltar as diferenças, e nesta leitura a astúcia não seria mais valorosa que a força, e o biógrafo então estaria recordando valores antigos romanos, em um momento de questionamento, em que a República começava a ruir. São possibilidades, entretanto, que só poderiam ser confirmadas se tivéssemos acesso a uma maior parte da obra do autor, sobretudo as vidas dos generais romanos.

Tais conclusões, entretanto, não podem ser aplicadas a todo gênero biográfico, mas apenas a Nepos. Suetônio e Plutarco, ambos autores de vidas muito mais extensas, organizam o material acerca dos biografados de maneira diferente.

Pudemos verificar que a seleção das res gestae acerca de Aníbal conhecidas pela tradição realizada por Nepos é essencial para a construção do caráter que Nepos deseja criar. A biografia difere da história por ser mais seletiva, e subordinar os acontecimentos ao caráter. Passando de maneira superficial por ações e consequências, Nepos tende a se concentrar em detalhes e anedotas que ilustram a imagem de Aníbal como general fiel ao seu ódio para com os romanos e um sumo estrategista. Verificamos também que, na biografia, os acontecimentos não estão inseridos em um nexo causal amplo como na historía; eles estão reunidos em torno

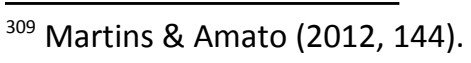

${ }^{310}$ Por exemplo, nada é dito sobre a vida familiar, sua esposa e seu filho, e poucas anedotas são mencionadas.
} 
da decisão do biografado. No caso da vida de Aníbal de Nepos, os limites do gênero parecem mais fundir-se com os do encômio, visto que o biógrafo constrói um retrato verbal laudatório, uma imago virtuosa do pior inimigo de sua nação. 


\section{CONCLUSÕES}

No primeiro capítulo, verificamos que os limites do gênero historiográfico e do que que era adequado ao gênero parecem ter variado até mesmo na Antiguidade. Entretanto, entre a maioria dos historiadores que chegou até nós, parece consenso que o relato da historía, arrogando para si o caráter de pesquisa do verdadeiro, deveria ser pautado em uma séria investigação. É também preponderante, nas obras dos historiadores que compõem o nosso cânone, a matéria política e militar, as res gestae de um povo. A escrita da história, entretanto, era também regulada pelas leis da Retórica, uma vez que qualquer discurso necessita também parecer verossímil. Neste sentido buscamos analisar quais as estratégias retóricas utilizadas por Tito Lívio e Cornélio Nepos para nos persuadir sobre como era o caráter de Aníbal. Vimos, entretanto, que a disciplina antiga da Retórica não é contrária à possibilidade do verdadeiro, já que buscava confirmá-lo com provas e entimemas. O uso de alguns procedimentos retóricos no relato histórico, quando não acompanhado de uma investigação criteriosa, no entanto, foi criticado por outros historiadores.

Na construção do êthos do general, seja em Lívio ou em Nepos, importam também elementos extradiscursivos, já que Aníbal era uma persona conhecida. É preciso não se afastar muito da fama que o general possuía, seja essa a fama passada de geração a geração, quanto a relatada por outros autores anteriores. Mas é na narrativa que Lívio e Nepos manipulam tal reputação construindo novos êthê através do discurso. Neste processo, os autores constroem o êthos através da narrativa de ações, descrições de comportamento e de traços psicológicos, convencionados por sua sociedade como próprios de um determinado tipo de caráter. Nesse sentido, como vimos, fica evidente que no processo de composição do êthos das personagens o autor lida com abstrações e convenções sociais, e não com a realidade.

Tito Lívio debruça-se sobre os acontecimentos públicos romanos desde a fundação de Roma, e na Terceira Década a matéria é a Segunda Guerra Púnica, sendo que o historiador organiza os acontecimentos geralmente sugerindo um nexo causal moral. O êthos de Aníbal insere-se neste projeto: alguns eventos, vitórias e derrotas, parecem ser resultantes de seu caráter e decisões. Através de sua própria voz, de descrições vívidas de ações, ou do jogo de vozes das personagens, Lívio constrói um caráter ambíguo, de grandes virtudes e vícios. A écfrase, com a sua principal qualidade, a vividez (enárgeia), fora utilizada na Historiografia 
para a amplificação de acontecimentos interessantes para a visão defendida, para o despertar de emoções, e ainda para colocar o descrito diante dos olhos do leitor, tornando-o testemunha ocular das ações, e contribuindo assim para a persuasão; o leitor vê assim os detalhes e a maneira como o narrador conta como verdadeiros. Como o efeito da enargia na mente do ouvinte é a phantasía, imagem mental, o procedimento é importante para manipular a percepção da recepção com relação ao evento descrito. Em Tito Lívio, as écfrases de batalhas, sobretudo as de Trasimeno e Canas, evidenciam a inteligência militar de Aníbal, e figuram a oposição entre essa e a cegueira mental das paixões. As batalhas até Canas ilustram a prudência de Aníbal versus a precipitação da maioria dos generais romanos. Os discursos diretos ao longo da narrativa são também elementos que conferem enárgeia ao texto, sendo que os do cartaginês diante das batalhas o apresentam também um grande comandante.

Mas o êthos que salta dessas claras descrições das ações militares é também complicado por outras caracterizações desde o início do livro 21. O retrato de sua juventude, emulando os retratos de Catilina e Jugurta de Salústio e manipulando o estereótipo do púnico, já alertava sobre um caráter de grandes virtudes e vícios terríveis. Mas a voz do narrador normalmente não aceita facilmente as versões que provam esses vícios terríveis. Poucas vezes vemos Lívio descrevendo crueldades do general com sua própria voz. São os discursos de outras personagens que frequentemente abordam os boatos mais terríveis sobre o general, provavelmente divulgados por outros historiadores, colocados em dúvida por Tito Lívio. As caracterizações, sejam elas feitas pela voz do historiador ou de outros, são construídas geralmente com base em estereótipos, principalmente o do pérfido, traiçoeiro, e do ambicioso; e neste processo o historiador imita outros modelos e personagens. Tal jogo de vozes acaba por turvar a imago de Aníbal, criando assim, no fim, uma imago ambígua, ou melhor, várias imagines de um Aníbal; o historiador busca assim dar conta de uma pluralidade de versões acerca das ações e do caráter do cartaginês.

Alguns episódios centrais, como a demora de Aníbal após Canas e a estadia em Cápua são sugeridos pelo historiador como causas da derrota cartaginesa. O primeiro erro é visto como decorrente do vício da cobiça, e a estadia em Cápua um erro estratégico que enfraquecera moralmente os soldados. Segundo a narrativa, o comportamento de Aníbal diante dos povos aliados, visto como uma falha de caráter pelo historiador, também o prejudicou no fim da guerra em solo itálico. Assim, Lívio parece sugerir causalidades morais aos rumos dos acontecimentos, e então seu êthos, de vícios, funciona como justificativa da má 
fortuna. E no momento em que vícios parecem cegar a estratégia de Aníbal, Cipião Africano começa a superá-lo, e na batalha de Zama, com os generais lado a lado, Aníbal é derrotado.

A imago ambígua de Aníbal, como dissemos, contribui para dois aspectos importantes na obra de Tito Lívio. O caráter de Aníbal é construído de maneira disseminada ao longo de uma extensa narrativa, em que o foco são as res gestae romanas, mas, no entendimento do historiador, os acontecimentos dependem sim do indivíduo. Assim, o caráter será é descrito de maneira a explicar e justificar os rumos da guerra; o caráter está a serviço das res gestae. Assim, o êthos vicioso coopera para o esquema causal da narrativa, pois justifica as derrotas cartaginesas, e consequentemente liga-se também à possível função pedagógica da obra, ao fornecer um exemplo do que deve ser evitado. E ao expor erros de Aníbal, como a estadia em Cápua, Lívio pode estar também aludindo a erros e vícios de seu tempo presente.

A imagem laudatória do general, além de justificar as vitórias iniciais do cartaginês, contribui para o louvor final de Roma, que o venceu, e também na narrativa convida os romanos a olharem no estrangeiro que virtudes lhes faltavam, e quais qualidades Roma deveria superar. Com os mesmos propósitos, Aníbal é louvado em suas poucas aparições na quarta década, caracterizado como um sábio em assuntos da guerra.

O êthos de Aníbal é construído por Nepos principalmente por meio da narrativa de suas ações, selecionadas de acordo com o objetivo do biógrafo, que não inclui na vida episódios que poderiam evidenciar os vícios a ele tradicionalmente associados, como a crueldade, perfídia e avareza. As ações, selecionadas, é que estão a serviço da construção de um determinado êthos, que é o foco da vida. Nepos, embora praticamente exclua a batalha de Canas do relato, narra com detalhes, dedicando muitas vezes parágrafos inteiros, episódios que ilustram a astúcia: o engano a Fábio Máximo, sua passagem por Creta, e a batalha naval contra Eumenes. Nepos ainda exalta a magistratura exercida por Aníbal em Cartago e sua dedicação às letras no fim da vida. Por centrar em apenas uma virtude, a inteligência, a narrativa parece construir um caráter mais tipificado, mais próxima de uma imago como um monumento público de homenagem a um general, plastificado a ponto de esconder as imperfeições. A imago criada por Nepos, é, sobretudo, a imago da estratégia. O biógrafo parece, assim, refletir sobre uma virtude do estrangeiro, talvez sugerindo que fosse imitada pelos romanos.

Ambas as imagines criadas pelos escritores são olhares de um romano para si através do outro. Nepos propõe claramente a comparação entre o romano e o estrangeiro, e discute 
virtudes e valores ao ressaltá-los através da vida do biografado. Lívio lida com uma maior complexidade de vícios, virtudes e exemplos de ações militares e políticas ao longo de uma obra muito mais extensa; não é tão fácil determinar os propósitos do historiador. Lívio não cria um manual de conduta, ele apenas sugere lições através do esquema de causalidades da obra, sistema esse também nada simples. O Aníbal de Lívio é ambíguo, assim como sua Roma, virtuosa no passado, mas que se deixara corromper. O êthos de Aníbal em Lívio explica as derrotas cartaginesas, mas também pode apontar erros romanos, do passado e do presente; assim também suas virtudes podem ter servido de exemplo aos romanos. Dessa maneira, as imagines dos generais cumprem importantes papeis nas obras, mas isso só é possível porque são construções discursivas, baseadas em estereótipos, convenções e paradigmas, abstrações da realidade, que, por isso, podem ser interpretadas por uma recepção apta. 


\section{BIBLIOGRAFIA}

\section{Autores Antigos:}

[Anônimo] (2005). Retórica a Herênio. Tradução e introdução de A. P. C. Faria e A. Seabra. São Paulo: Hedra.

Aftônio, Hermógenes, Nicolau, Teão (2003). Progymnasmata : Greek textbooks of prose composition and rhetoric, translated with introductions and notes by George A. Kennedy. Atlanta: Society of Blibical Literature.

Aristóteles (2007). De anima. Apresentação, tradução e notas de Maria Cecília Gomes dos Reis. São Paulo: Editora 34.

(2005). Retórica. Tradução e notas de M. Alexandre Júnior, P. F. Alberto e A. N.

Pena. Lisboa: Imprensa Nacional; Casa da Moeda.

(2002) Poetics. Introduction, commentary and appendixes by D. W. Lucas. Oxford, Clarendon Press, 2002.

(1991). Ética a Nicômaco ; Poética . Ética a Nicômaco. Tradução de Leonel

Vallandro e Gerd Bornheim da versão inglesa de W.D. Ross ; Poética :

tradução, comentários e índices analítico e onomástico de Eudoro de Souza.

Coleção Os Pensadores . 4. ed. São Paulo: Nova Cultural. (1965). Aristotelis de arte poetica liber by R. Kassel. Oxford: Clarendon Press. (1961). Aristotle De anima by W. D. Ross.Oxford: Clarendon Press, 1961. (1959). Aristotelis ars rhetorica by W.D. Ross. Oxford: Clarendon Press. (1894). Aristotelis ethica Nicomachea by I. Bywater. Oxford: Clarendon Press. (s/d) Poética. Trad., comentários e índices analístico e onomástico de Eudoro de Souza. São Paulo: Abril.

Cicero (1988). De Oratore, books 1-2. Translation by E. W. Sutton. Cambridge, Mass.: Harvard University Press

(1979). De Senectute, De Amicitia, De Divinatione. Tr. W. A. Falconer. Cambridge, Mass: Harvard University Press.

(1915). De Finibus Bonorum et Malorum (M.Tulli Ciceronis Scripta Quae Manserunt Omnia. Fasc. 43, ed. T. Schiche.

Diógenes Laércio (1997). Vidas e Doutrinas dos Filósofos Ilustres. Trad. De Mário da Gama Kury. Brasília: Editora UNB.

Dionísio de Halicarnaso (2000). Critical Essays. Vol. I. Translation by Stephen Usher. Cambridge, Mass.; London: Harvard University Press.

(1929). Dionysii Halicarnasei quae exstant, L. Radermacher and H. Usener. Vol. 6. Leipzig: Teubner. 
Filóstrato (1979). Philostratus. The Elder. The Younger. Imagines. Callistratus Descriptions. London: Harvard University Press.

(1893). Philostrati maioris imagines, O. Benndorf and K. Schenkl Leipzig: Teubner.

Hermógenes (1913). Hermogenis opera by H. Rabe. Leipzig: Teubner.

Horácio (1984). Arte Poética. Introdução, tradução e comentário de R. M. Rosado Fernandes. Lisboa: Editorial Inquérito.

(1941). Obras completas. Tradução de Elpino Duriense, J. A. De Macedo, A. L. De Seabra e F. A. Picot. São Paulo: Edições Cultura, 1941.

Heródoto (1994). Histórias. Livro $1^{\circ}$. Introd. Geral de M. H. da Rocha Pereira; Introd., Tradução e notas de J. R. Ferreira e M. de F. Silva. Lisboa: Edições 70. (1932-39). Hérodote. Histoires, by E. Legrand. 9 vols. Paris: Les Belles Lettres.

Justino (1853). Epitome of the Phlippic History of Pompeius Trogus. Translated, with notes, by the Rev. J. S.Watson. London: Henry G. Bohn.

Longino (1996). Do Sublime. Tradução de Filomena Hirata. São Paulo: Martins Fontes. (1964). Longinus'. On the sublime by D.A. Russell. Oxford: Clarendon Press.

Luciano (1990). How to write History. In: Lucian, Vol VI. Translation by K. Kilburn. Cambridge, Mass; London: Harvard University Press.

(1905). The Works of Lucian of Samosata, Volume III, Tr. by H. W. Fowler and F. G. Fowler, Oxford: The Clarendon Press.

Nepos (2002). Cornelius Nepos. Erllärt von K. Nipperdey. Herausgegeben von K. Witte. Berlin: Weidmann.

(1895). Vidas. Introducción, tradución y notas de Manuel Segura Moreno. Madrid: Editorial Gredos.

(1984). Cornelius Nepos. With an english translation by John C. Rolfe. Cambridge,Mass;London: Harvard University Press; William Heinemann, 1984.

(1882). Cornelius Nepos. Commentaire critique et et explicative et une introduction par Alfred Monginot. Paris: Hachette.

Nicolau (1913). Nicolai progymnasmata, J. Felten. [Rhetores Graeci]11. Leipzig: Teubner.

Plínio (1983). Natural History. Tr. H. Rackham. Cambridge, Mass.: Harvard Univversity Press.

Plutarco (2002). Obras Morales y de Costumbres. Tradución V. R. Palerm y J. B. Cavero. Madrid: Editorial Gredos.

(1994). Lives. Aratus, Artaxerxes, Galba, Otho. Translation by Bernadotte Perrin. Cambridge; London: Harvard University Press. 
(1991). Alexandre e César. Tradução de Hélio Vega. São Paulo: Atena Editora.

(1991b) Vidas Paralelas. Vol. 3. Tradução de Gilson César Cardoso. São Paulo: Paumape.

(1964-71). Plutarchi vitae parallelae, K. Ziegler. Vol. 1-3. Leipzig: Teubner.

(1954). Plutarch's Lives. With an English translation by B. Perrin. Vol VI. London:

William Heinemann; Cambridge,Mass.: Harvard University Press.

(1935) Plutarchi moralia, W. Nachstädt vol. 2.2. Leipzig: Teubner, 1935.

Políbio (1985). História. Tradução de Mário da Gama Kury. Brasília: Editora da Universidade de Brasília, 1985.

(1962-7). Polybii historiae, T. Büttner-Wobst. Leipzig: Teubner.

(1954). The Histories. With an English translation by W. R. Paton. Vol I-VI. London:

William Heinemann; Cambridge,Mass.: Harvard University Press.

Quintiliano (1996). Institutio Oratoria. Books I-III. London: Harvard University Press.

Salústio/Sêneca (1990). Tratado sobre a clemência. A conjuração de Catilina. A Guerra de Jugurta. Tradução de Antonio Silveira Mendonça. Petrópolis, RJ: Vozes.

Salústio (1924). Salluste. Conjuration de Catilina. Guerre de Jugurtha. Texte Établi par B. Ornstein. Paris: Les Belles-Lettres, 1924.

Sêneca (1985-90). Moral essays. Translation bu J. W. Basore. Cambridge, Mass: Harvard University Press.

Suetônio (1979). Suetonius. Tr. J. C. Rolfe. Cambridge, Mass.: Harvard University Press, 1979.

Theon (1854). Progymnasmata in L. Spengel, Rhetores Graeci, vol. 2. Leipzig: Teubner.

Tito Lívio (1993). Historia de Roma desde su fundación. Tomos I-V. Tradución y notas de José Antonio Villar Vidal. Madrid: Gredos.

(1970-91). Livy. Books I- XLV. With an English translation by B. O. Foster ; [Frank Gardner Moore; Evan T. Sage; Alfred C. Schlesinger]. The Loeb classical library : 114, 133, 172, 191, 233, 295, 301, 313, 332, 355, 367, 381, 396, 404. Cambridge, MA; London : Harvard University Press: W. Heinemann, 1970-1991.

\section{Autores Modernos:}

R. Ambrosio (2005). De rationibus exordiendi: os princípios da história em Roma. São Paulo: Associação Editorial Humanitas. 
P. Asso (2010). Hercules as a paradigm of Roman Heroism. In: A. Augoustakis. Brill's Companion to Silius Italicus. Leiden; Boston: Brill.

J. S. Baumlin (2001). Êthos. In: T. O. Sloane (2001). Encyclopedia of Rhetoric. Oxford, New York: Oxford University Press, 263-277.

H. Beck (2007). The early Roman Tradition. In: J. Marincola (Ed.) (2007). A companion to Greek and Roman Historiography. Vol. I-II. UK, Oxford: Blackwell Publishing.

J. E. Bernard (2000). Le portrait chez Tite-Live. Latomus, 253. Bruxelles.

M. W. Blundell (1992). Ethos and Dianoia Reconsidered. In: A. O. Rorty (Ed) Essays on Aristole's poetics. New Jersey: Princeton University Press.

G. Cerri; B. Gentili (1988). History and Biography in Ancient Thought. Amsterdam: J. C. Gieben.

J. D. Chaplin (2000). Livy's Exemplary History. Oxford: Oxford University Press.

Chantraine (1968). Dictionnaire étymologique de la Langue Grecque. Paris: Edition Klincksieck.

A. Chiappeta (1996). 'Não diferem o historiador e o poeta...' O texto histórico como instrumento e objeto de trabalho. In: Lingua e literatura, 22: 15-34.

K. Clarke (1999). Universal perspectives in Historiography. In: C. S. Kraus. The limits of Historiography: genre and narrative in ancient historical texts. Leiden, Boston, Koln: Brill.

J. J. Clauss (1997). "Domestici Hoste"s: The Nausicaa in Medea, the Catiline in Hannibal. In: Materiali e discussioni per l'analisi dei testi classici, 39: 165-185.

Darbo-Peschanki (2007).The Origin of Greek Historiography. In: J. Marincola. A companion to Greek and Roman Historiography. Vol. I-II. UK, Oxford :Blackwell Publishing.

A. C. Dionisotti (1988). Nepos and the Generals. The Journal of Roman Studies, Vol.78 : $35-$ 49.

T. A. Dorey (1971). Livy. London : Routledge and K. Paul.

S. Dubel (1997). Ekphrasis et enargeia: la description antique comme parcours" In: C. Lévy \& L. Pernot. Dire L'Évidence. Cahiers de philosophie de l'Université de Paris XII- Val de Marne número 2. L'Harmattan.

E. C. Evans (1935). Roman Descriptions of Personal Appearance in History and Biography. Harvard Studies in Classical Philology, Vol. 46; 43-84.

A. Feldherr (1998). Spectacle and Society in Livy's History. Berkeley; Los Angeles;London: University of California Press. 
M. Finley (1989). Mito, Memória e História. In: Uso e Abuso da História. São Paulo: Matins Fontes.

C. W. Fornara (1983). The nature os History in Ancient Greece and Rome. Berkeley; Los Angeles; London: University of California Press.

M. Foulkes (1999). Livy's Characterisation of Individuals and Races in Book XXI. In: Histos, 3: $70-76$.

G. F. Franko (1994). The Use of Poenus and Carthaginiensis in Early Latin Literature. In: Classical Philology, 89: 153-158.

J. Geiger (1985). Cornelius Nepos and Ancient Politiccal Biography. Historia Eizenlschriften. Franz Steiner Verlag Wiesbaden. Stuttgart.

G. Genette (1969). Frontières du Récit. In: Figures II. Paris: Éditions du Seuil, 50-61.

C. Ginzburg (2007). O fio e os rastros: verdadeiro, falso, fictício. São Paulo: Companhia das Letras.

(2002). Relações de Força. História, retórica, prova. São Paulo: Companhia das Letras.

P. G. W. Glare, ed. (1968). Oxford Latin Dictionary. Oxford: Clarendon Press.

A. Grénier (1969). Le genie romain dans la religion, la pensée et l'art. Paris: Albin Michel.

T. Hägg; P. Rousseau (2000). Greek Biography and Panegyric in Late Antiquity. Berkeley; Los Angeles; London: University of California Press.

F. Hartog (Org.) (2001). A História de Homero a Santo Agostinho. Prefácios de Historiadores e texto sobre História reunidos e comentados por F. Hartog e traduzidos para o português por J. L. Brandão. Belo Horizonte: Editora UFMG.

M. Jaeger (1999). Guiding metaphor and narrative point of view in Livy's Ab Vrbe Condita. In: C. S. Kraus. The limits of Historiography: genre and narrative in ancient historical texts. Leiden, Boston, Koln: Brill.

J. D. Jefferis (1943). The concept of Fortuna in Cornelius Nepos. Classical Philology, Vol 38, $\mathrm{N}^{\mathrm{0}} 1: 48-50$.

B. Knox (2002). Édipo em Tebas. O herói trágico de Sófocles e seu tempo. São Paulo: Perspectiva.

H. Lausberg (2004). Elementos de Retórica Literária. Tradução de R.M. Rosado Fernandes. Lisboa : Fundação Calouste Gulbenkian.

(1991) Manual de Retórica Literária. Vérsion espanõla de J. P. Riesco. Vol I-III. Madrid: Editorial Gredos. 
D.S. Levene (2007). Roman Historiography in the Late Republic. In: J. Marincola (Ed.) (2007). A companion to Greek and Roman Historiography. Vol. I-II. UK, Oxford :Blackwell Publishing.

C.T. Lewis; C. Short. (1879). A Latin Dictionary. Founded on Andrews' edition of Freund's Latin dictionary. Oxford. Clarendon Press.

L. E. Lord (1927). The Biographical Interests of Nepos. The Classical Journal. Vol 22, No.7: 498-503.

T. J. Luce (1977). Livy. The composition of His History. Princeton: Princeton University Press.

A. MacC. Armstrong (1958). The Methods of the Greek Physiognomists. Greece \& Rome, Second Series, Vol. 5, No. 1: 52-56.

F. Millar (1988). Cornelius Nepos, 'Atticus' and the Roman Revolution. Greece \& Rome, Second Series, Vol. 35, No .1: 40-55.

L. O. Magalhães (2009). Resenha: Silva, M. Ap. O. Plutarco Historiador: Análises das Biografias Espartanas”. História da Historiografia. N.3: 181-187. Ouro Preto.

Maingueneau, D. (2008). Cenas da enunciação. Org. S. Possenti, M. C. P. Souza-e-Silva. São Paulo: Parábola Editorial.

J. Marincola (Ed.) (2007). A companion to Greek and Roman Historiography. Vol. I-II. UK, Oxford: Blackwell Publishing. (1999). Genre, Convention, and Innovtion in Greco-Roman Historiography. In: C. S. Kraus, ed. The Limits of Historiography. Leiden; Boston; Köln: Brill.

P. Martins (2011). Imagem e Poder. Considerações sobre a representação de Otávio Augusto. São Pulo: Edusp, 2011. (2009). Elegia Romana construção e efeito. São Paulo: Humanitas.

P. Martins; R. S. S Amato (2012). Imagens Antigas Retoricamente Referenciadas. In: A. Muhana; M. Laudanna; L. A. Bagolin (Org.). Retórica. São Paulo: Annablume Editora, 125-145.

J. L. Moles (2009). Livy's Preface. In: J. D. Chaplin \& C. S. Kraus (Eds.). Livy. Oxford: Oxford University Press.

T. J. Moore (2010). Livy's Hannibal and the Roman Tradition. In: W. Polleichtner (Ed.). Livy and Intertextuality. Trier: WVT Wissenschaftlicher Verlag Trier.

(1989). Artistry and Ideology: Livy's Vocabulary of Virtue. (Beiträge zur Klassichen Philologie, 192). Frankfurt am Main: Athenaum.

A. Momigliano (1993). The Development of Greek Biography. Expanded edition. Cambridge, Mass; London: Harvard University Press.

(1971). Second Thoughts on Greek Biography. Amterdam; London: NorthHollard Publishing Company. 
R. Nicolai (2007) The Place of History in the Ancient World. In: Marincola (Ed.). A companion to Greek and Roman Historiography. Vol. I-II. Oxford :Blackwell Publishing.

M. G. Novak; M. L. Neri ; A. A. Peterline, orgs. (1999). Historiadores Latinos: Antología Bilingüe. São Paulo: Martins Fontes.

R. M. Ogilvie (2000). Livy. In: The Cambridge History of Classical Literature, pt.3, vol.II. Cambridge: Cambridge University Press.

A. S. Osley (1946). Greek Biography before Plutarch. Greece \& Rome, Vol. 15, No. 43; 720.

H. Petersen (1961) Livy and Augustus. Transactions and Proceedings of the American Philological Association, Vol. 92: 440-452.

M. Rodolpho (2010). Écfrase e Evidência nas Letras Latinas: Doutrina e Práxis. São Paulo: FFLCH-USP. Dissertação de Mestrado.

(2012). "O êthos na fisionomia", artigo no prelo. Apresentado no III Colóquio

Visões da Antiguidade, São Paulo - PPG Letras Clássicas, USP, 25 a 27 de julho de 2012.

A. Rossi (2004). Parallel Lives: Hannibal and Scipio in Livy's Third Decade. In: Transactions of the American Philological Association, 134: 359-381.

R. Rutherford (2007). Tragedy and History. In: J. Marincola (Ed.). A companion to Greek and Roman Historiography. Vol. I-II. Oxford :Blackwell Publishing.

M. M. Sage (1978). The De Viris Illustribus: Chronology and Structure. Transactions of the American Philological Association, Vol. 108; 217- 241.

A. Scatolin (2009). A invenção no Do orador de Cícero: um estudo à luz de Ad Familiares I, 9, 23. São Paulo: FFLCH-USP. Tese de Doutorado.

B. B. Sebastiani (2007). Políbio contra Filarco, ou crítica à historiografia trágica In: Hypnos, São Paulo, n. 19: 68-84.

(2006). A política como objeto de estudo: Tito Lívio e a reflexão historiográfica romana do século I a.C., Revista de história,. n.154, 297315 .

M. A. O. Silva (2006). Plutarco Historiador: Análises das Biografias Espartanas. São Paulo: Editora da Universidade de São Paulo.

P. Stadter (2007). Biography and History. In:J. Marincola (Ed.). A companion to Greek and Roman Historiography. Vol. I-II. Oxford :Blackwell Publishing.

R. Syme (1960). The Roman revolution. London: Oxford University Press. 
F. Titchner (2003). F. "Cornelius Nepos and the biographical tradition" Greece \& Rome, Seccond Series, Vol. 50: 85-99.

P. M. Veyne (1995). Como se escreve a história. Focault revoluciona a história. $3{ }^{\mathrm{a}} \mathrm{ed}$. Brasília: Editora Universidade de Brasília.

F. W. Walbank (1985). History and Tragedy. In: Selected Papers. Studies in Greek and Roman history and Historiography. Cambridge: Cambridge University Press.

A. D. Walker (1993). Enargeia and the Spectator in Greek Historiography. In: TAPA, 123: 353-377.

T. P. Wiseman (1993). Lying Historians: Seven Types of Mendacity. In: C. Gill \& T. P. Wiseman. Lies and Fiction in the Ancient World. Exeter: University of Exeter Press.

P. G. Walsh (1961). Livy, his Historical Aims and Methods. Cambridge: University Press. (1954). The literary techniques of Livy. In: Rheinischer Museum fur Philologie, 97: 97-114.

R. Webb (2009). Ekphrasis, Imagination and Persuasion in Ancient Rhetorical Theory and Practice. England; USA: Ashgate, 2009.

H. White (1994). Trópicos do Discurso. São Paulo: Edusp.

J. Wisse (1989). Ethos and Pathos from Aristotle to Cicero. Amsterdam: Hakkert, 1989.

A. J. Woodman (1988). Rhetoric in Classical Historiography: four studies. Portland, Oregon: Areopagitica Press. 


\section{ANEXOS}

\section{Figura 1:}

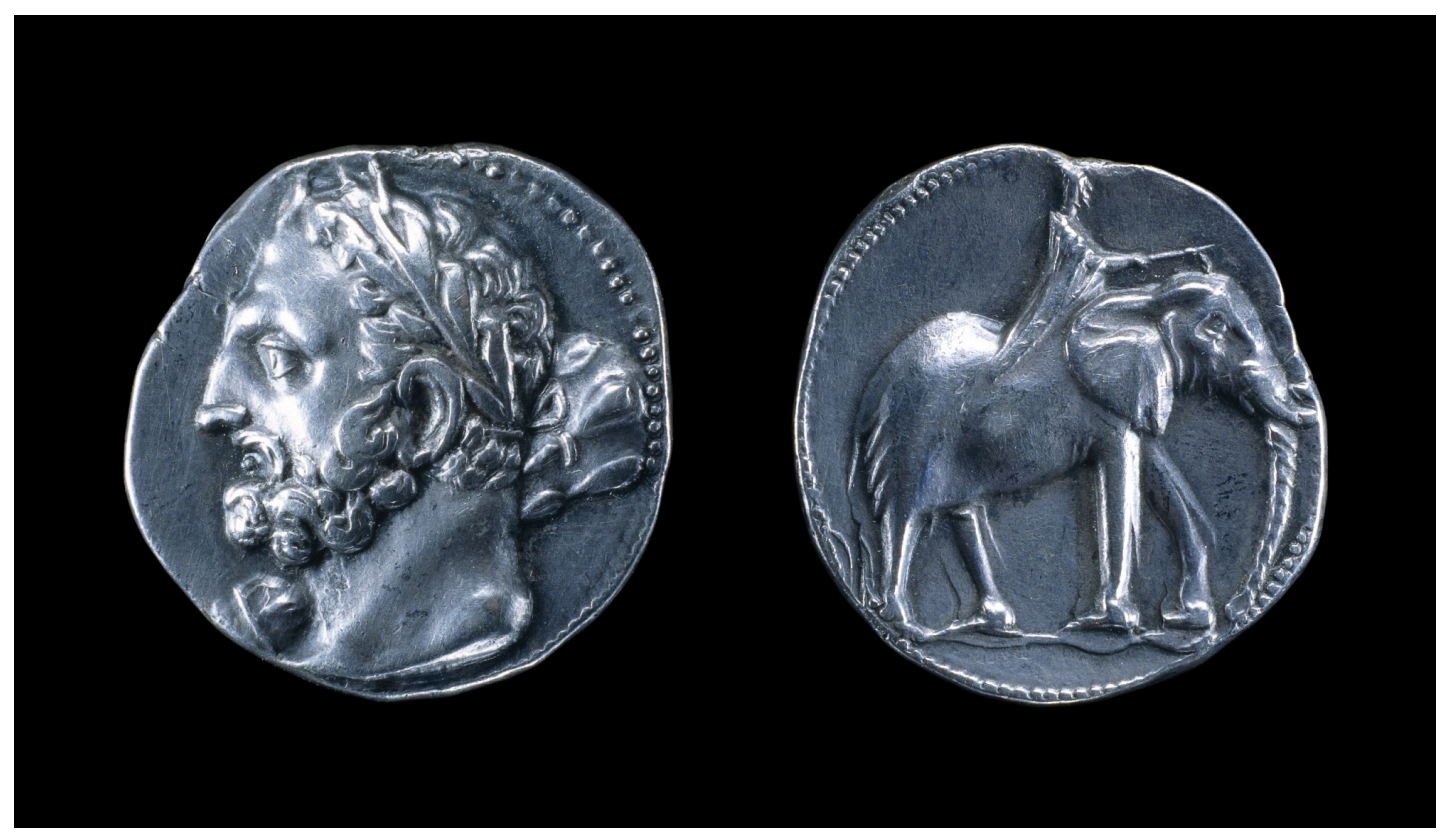

Museu Britânico - CM 1911-7-2-1 (IGCH 2328)

Mogente, Valência, Espanha, aprox. 230 a. C.

Imagem disponível em:

http://www.britishmuseum.org/explore/highlights/highlight_objects/cm/s/silver_double_shekel_of_cartha.aspx 


\section{Tradução da Vida de Aníbal, de Cornélio Nepos ${ }^{311}$}

[1] HANNIBAL, Hamilcaris filius, Karthaginiensis. Si verum est, quod nemo dubitat, ut populus Romanus omnes gentes virtute superarit, non est infitiandum Hannibalem tanto praestitisse ceteros imperatores prudentia quanto populus Romanus antecedat fortitudine cunctas nationes. Nam quotienscumque cum eo congressus est in Italia, semper discessit superior. Quod nisi domi civium suorum invidia debilitatus esset, Romanos videtur superare potuisse. Sed multorum obtrectatio devicit unius virtutem.

Hic autem, velut hereditate relictum, odium paternum erga Romanos sic conservavit, ut prius animam quam id deposuerit, qui quidem, cum patria pulsus esset et alienarum opum indigeret, numquam destiterit animo bellare cum Romanis. [2] Nam ut omittam Philippum, quem absens hostem reddidit Romanis, omnium iis temporibus potentissimus rex Antiochus fuit. Hunc tanta cupiditate incendit bellandi, ut usque a rubro mari arma conatus sit inferre Italiae.

Ad quem cum legati venissent Romani, qui de eius voluntate explorarent darentque operam, consiliis clandestinis ut Hannibalem in suspicionem regi adducerent, tamquam ab ipsis corruptus alia atque antea sentiret, neque id frustra fecissent idque Hannibal comperisset seque ab interioribus consiliis segregari vidisset, tempore dato adiit ad regem, eique cum multa de fide sua et odio in Romanos commemorasset, hoc
[1] Aníbal, cartaginês, filho de Amílcar. Se é verdade - o que ninguém duvida - que a nação romana superou todos os povos em virtude, não se deve negar que Aníbal precedeu todos os outros comandantes em habilidade militar ${ }^{312}$, assim como o povo romano todas as nações em força. Pois todas as vezes que lutou contra romanos em solo itálico, saiu vitorioso. E se não tivesse sido enfraquecido pela inveja de seus compatriotas, aparentemente poderia tê-los derrotado. Mas o ódio de muitos prevaleceu sobre a virtude de um.

Aníbal, porém, conservou intacto o ódio a Roma herdado do pai, a ponto de que abdicaria de sua vida antes que desse ódio. De fato, mesmo quando foi expulso de sua pátria e necessitou de recursos alheios, nunca em seu pensamento desistiu de guerrear contra os romanos. [2] Naquele tempo, o rei mais poderoso de todos era Antíoco $^{313}$, com exceção de Filipe $^{314}$, o qual Aníbal, mesmo distante, converteu em inimigo romano. No primeiro, Aníbal acendeu o desejo de guerra de tal maneira que até tentou levar as armas à Itália através do mar vermelho ${ }^{315}$.

Quando os embaixadores romanos vieram até Aníbal [na corte de Antíoco] a fim de investigar seus propósitos, fizeram com que o rei suspeitasse, por causa das conversações secretas, de que Aníbal havia sido corrompido e havia mudado de opinião. Tal artimanha não foi em vão, e Aníbal, tendo descoberto o plano e vendo-se apartado das decisões interiores da corte, foi até o rei em momento oportuno e, recordando muitas palavras sobre sua fidelidade e ódio contra os

\footnotetext{
${ }^{311} \mathrm{O}$ texto latino utilizado para a tradução, e abaixo reproduzido, compreende a versão da Loeb Classical Library (Cornelius Nepos. Cambridge, Mass: Harvard University Press, 1984).

312 O termo latino é prudentia, que significa também prudência, mas entendemos como como Monginot (1882), que indica a expressão comum prudens rei militaris, expressão também atestada por Saraiva (2006).

${ }^{313}$ Antíoco III, o Grande, rei da Síria entre 223 e 187 (Nipperdey, 2002).

${ }^{314}$ Monginot (1882) aponta que se trata de Filipe III, rei da Macedônia pai de Perseus. Ele teria firmado uma aliança com Aníbal após a batalha de Cannas. Entretanto, Nipperdey (2002) afirma que se trata de Felipe V, rei entre 220-179.

${ }^{315}$ Os antigos designavam de mar vermelho todo o mar que se estendia ao sul da Ásia, desde a península da Índia até a costa da África (Monginot, 1882). Não apenas o mar arábico, mas também Persa e Índico (Nipperdey, 2002).
} 
adiunxit: "Pater meus", inquit, "Hamilcar puerulo me, utpote non amplius novem annos nato, in Hispaniam imperator proficiscens, Karthagine Iovi optimo maximo hostias immolavit. Quae divina res dum conficiebatur, quaesivit a me, vellemne secum in castra proficisci. Id cum libenter accepissem atque ab eo petere coepissem ne dubitaret ducere, tum ille, 'Faciam', inquit, 'si mihi fidem quam postulo dederis.' Simul me ad aram adduxit apud quam sacrificare instituerat eamque ceteris remotis tenentem iurare iussit numquam me in amicitia cum Romanis fore. Id ego iusiurandum patri datum usque ad hanc aetatem ita conservavi, ut nemini dubium esse debeat quin reliquo tempore eadem mente sim futurus. Quare si quid amice de Romanis cogitabis, non imprudenter feceris, si me celaris; cum quidem bellum parabis, te ipsum frustraberis, si non me in eo principem posueris."

[3] Hac igitur qua diximus aetate cum patre in Hispaniam profectus est, cuius post obitum, Hasdrubale imperatore suffecto, equitatui omni praefuit. Hoc quoque interfecto, exercitus summam imperii ad eum detulit. Id Karthaginem delatum publice comprobatum est. 2 Sic Hannibal, minor $V$ et $X X$ annis natus imperator factus, proximo triennio omnes gentes Hispaniae bello subegit, Saguntum, foederatam civitatem, vi expugnavit, tres exercitus maximos comparavit. Ex his unum in Africam misit, alterum cum Hasdrubale fratre in Hispania reliquit, tertium in Italiam secum duxit. Saltum Pyrenaeum transiit; quacumque iter fecit, cum omnibus incolis conflixit, neminem nisi victum dimisit.

Ad Alpes posteaquam venit, quae Italiam ab Gallia seiungunt, quas nemo umquam cum exercitu ante eum praeter Herculem Graium transierat - quo facto is hodie saltus Graius appellatur - Alpicos conantes prohibere transitu concidit, loca patefecit, itinera muniit, effecit, ut ea elephantus ornatus ire posset qua antea unus homo inermis vix poterat repere. Hac copias traduxit in Italiamque pervenit. romanos, disse o seguinte: "Meu pai Amílcar, imperador na Hispânia, após deixar Cartago, imolou sacrifícios a Júpiter Óptimo Máximo quando era eu um menino de não mais que nove anos. Enquanto este sacrifício divino era preparado, perguntou-me se queria ir consigo ao acampamento. Quando de bom grado disse que iria e já começava a pedir-lhe que não hesitasse em levar-me, ele respondeu: "Assim farei se me concederes o juramento que te peço". Naquela instante me conduziu ao altar onde se iniciava o sacrifício e, tendo feito os outros se retirarem, impôs as mãos sobre mim e ordenou-me jurar que eu nunca seria amigo dos romanos. Este juramento, feito a meu pai, guardei até este momento, e ninguém deve duvidar de que não terei mesma índole no futuro. Por esta razão, se conjecturas algo de amizade romana, agirias com prudência se ocultasses a mim; mas, se preparas a guerra contra eles, tu falharás se não me tiver como o primeiro no comando."

[3] Com essa idade que mencionamos, Aníbal partiu para a Hispânia com o pai. Depois da morte deste, Asdrúbal tornou-se o comandante, e Aníbal ficou à frente de toda a cavalaria. Após Asdrúbal ser assassinado, o exército entregou a Aníbal o sumo comando. Isto foi relatado à Cartago e aprovado por decreto oficial. Assim, Aníbal tornou-se capitão com apenas vinte e cinco anos de idade. E nos três anos seguintes subjugou todos os povos da Hispânia com a guerra, atacou com violência Sagunto, cidade aliada dos romanos, e reuniu três grandes exércitos. Um deles enviou à África, outro deixou com seu irmão Asdrúbal na Hispânia, e o terceiro levou consigo para a Itália. Atravessou os montes Pirineus, combatendo todos os habitantes pelo caminho, seja qual ele tenha sido: ninguém saiu vitorioso.

Em seguida, chegou aos Alpes, que separam a Itália da Gália, montanhas que nunca antes ninguém atravessara com exército (com exceção do Hércules Grego, e por isto hoje os montes são chamados de gregos). Destruiu as tribos alpinas que impediam a passagem, desvendou regiões e estabeleceu uma rota, fazendo com que elefantes, equipados, passassem por onde antes só poderia passar, com dificuldade, um único homem desarmado. Através deste caminho conduziu o exército e chegou à Itália. 
[4] Conflixerat apud Rhodanum cum P. Cornelio Scipione consule eumque pepulerat. Cum hoc eodem Clastidi apud Padum decernit sauciumque inde ac fugatum dimittit. Tertio idem Scipio cum collega Ti.o Longo apud Trebiam adversus eum venit. Cum his manum conseruit utrosque profligavit. Inde per Ligures Appenninum transiit, petens Etruriam. Hoc itinere adeo gravi morbo afficitur oculorum, ut postea numquam dextro aeque bene usus sit. Qua valetudine cum etiam tum premeretur lecticaque ferretur, C. Flaminium consulem apud Trasumenum cum exercitu insidiis circumventum occidit, neque multo post $C$. Centenium praetorem cum delecta manu saltus occupantem.

Hinc in Apuliam pervenit. Ibi obviam ei venerunt duo consules, $C$. Terentius et L. Aemilius. Utriusque exercitus uno proelio fugavit, Paulum consulem occidit et aliquot praeterea consulares, in his Cn. Servilium Geminum, qui superiore anno fuerat consul.

[5] Hac pugna pugnata, Romam profectus nullo resistente, in propinquis urbi montibus moratus est. Cum aliquot ibi dies castra habuisset et Capuam reverteretur, $Q$. Fabius Maximus, dictator Romanus, in agro Falerno ei se obiecit. Hic, clausus locorum angustiis, noctu sine ullo detrimento exercitus se expedivit Fabioque, callidissimo imperatori, dedit verba; namque obducta nocte sarmenta in cornibus iuvencorum deligata incendit eiusque generis multitudinem magnam dispalatam immisit. Quo repentino obiecto visu tantum terrorem iniecit exercitui Romanorum, ut egredi extra vallum nemo sit ausus. Hanc post rem gestam non ita multis diebus M. Minucium Rufum, magistrum equitum pari ac dictatorem imperio, dolo productum in proelium, fugavit. Ti. Sempronium Gracchum, iterum consulem, in Lucanis absens in insidias inductum sustulit. M. Claudium Marcellum, quinquies consulem, apud Venusiam pari modo interfecit.

Longum est omnia enumerare proelia. Qua re hoc unum satis erit dictum, ex quo intellegi possit quantus ille fuerit: quamdiu in Italia fuit, nemo ei in acie restitit,
[4] Enfrentou o cônsul Públio Cornélio Cipião junto ao Ródano, fazendo-o fugir. Contra este combateu também em Clastídio, junto ao rio Pó, despedindo-o dali ferido e fugitivo. Uma terceira vez o mesmo Cipião foi adversário de Aníbal, juntamente com Tibério Longo, em Trébia. Com ambos empreendeu combate direto e venceu. De lá atravessou os Apeninos pela Ligúria, aproximando-se da Etrúria. Nesta viagem, foi acometido por uma grave enfermidade dos olhos de tal modo que nunca mais enxergou da mesma maneira com o olho direito. Enquanto era acometido por este mal, sendo carregado em uma liteira, Aníbal bateu o cônsul Gaio Flamínio com uma emboscada para seu exército em Trasimeno, e pouco tempo depois o pretor Gaio Centênio, que ocupava o desfiladeiro com as tropas recrutadas.

Em seguida chegou à Apúlia. Ali vieram ao seu encontro dois cônsules, Gaio Terêncio e Lúcio Emílio. Em uma única batalha Aníbal pôs em fuga os exércitos de ambos, matou o cônsul Paulo, além de outros consulares, entre os quais Gneo Servílio Gemino, que havia sido cônsul no ano anterior.

[5] Vencida esta batalha, avançou em direção a Roma sem nenhuma resistência, e acampou nos montes próximos à cidade. Enquanto Aníbal, após Aníbal ter se demorado lá alguns dias, retornava a Cápua, o ditador romano Quinto Fábio Máximo apresentou-se contra ele nos campos de Falerno. Aníbal, encurralado por um desfiladeiro, fez sair o seu exército durante a noite sem dano algum, enganando a Fábio, o mais experto dos generais: na escuridão da noite, ateou fogo em galhos de videira amarrados nos chifres de bezerros que, em grande número, correram para diversas direções. Quando se deparou com esta imagem inesperada o exército romano encheu-se de tanto pavor que ninguém ousou sair da trincheira. Após estes acontecimentos, passados poucos dias, fez fugir Marco Minúcio Rufo, chefe da cavalaria, que estava na condição de substituto do ditador, e entrara em confronto sem autorização. Mesmo ausente, (Aníbal) derrotou o cônsul Tibério Semprônio Graco, conduzido a emboscadas na Lucânia. E da mesma maneira, em Venúsia, matou Marco Cláudio Marcelo, cônsul pela quinta vez.

Seria uma tarefa longa enumerar todas as batalhas.. Será suficiente relatar um único fato sobre elas, a partir do qual se poderá compreender o valor deste 
nemo adversus eum post Cannensem pugnam in campo castra posuit.

[6] Hinc invictus patriam defensum revocatus, bellum gessit adversus $P$. Scipionem, filium eius quem ipse primo apud Rhodanum, iterum apud Padum, tertio apud Trebiam fugarat. Cum hoc, exhaustis iam patriae facultatibus, cupivit impraesentiarum bellum componere, quo valentior postea congrederetur. In colloquium convenit, condiciones non convenerunt. Post id factum paucis diebus apud Zamam cum eodem conflixit, pulsus - incredibile dictu - biduo et duabus noctibus Hadrumetum pervenit, quod abest ab Zama circiter milia passuum trecenta. In hac fuga Numidae qui simul cum eo ex acie excesserant insidiati sunt ei, quos non solum effugit, sed etiam ipsos oppressit. Hadrumeti reliquos e fuga collegit, novis dilectibus paucis diebus multos contraxit.

[7] Cum in apparando acerrime esset occupatus, Karthaginienses bellum cum Romanis composuerunt. Ille nihilo setius exercitui postea praefuit resque in Africa gessit $^{316}$ usque ad P. Sulpicium C. Aurelium consules. His enim magistratibus legati Karthaginienses Romam venerunt, qui senatui populoque Romano gratias agerent, quod cum iis pacem fecissent ob eamque rem corona aurea eos donarent simulque peterent ut obsides eorum Fregellis essent captivique redderentur. His ex senatus consulto responsum est: munus eorum gratum acceptumque esse; obsides quo loco rogarent futuros; captivos non remissuros, quod Hannibalem, cuius opera susceptum bellum foret, inimicissimum nomini Romano, etiamnunc cum imperio apud exercitum haberent itemque fratrem eius Magonem. Hoc responso Karthaginienses cognito, Hannibalem domum et Magonem revocarunt. Huc ut rediit, rex factus est, postquam praetor fuerat anno secundo et vicesimo - ut enim Romae consules, sic Karthagine quotannis homem: enquanto esteve na Itália, ninguém pode resistir a ele em batalha, e após Canas, ninguém se arriscou a montar acampamento em campo a sua frente.

[6] Aníbal, invicto, foi chamado de volta para defender sua pátria e comandou a guerra contra Públio Cipião, filho daquele mesmo Cipião que fizera fugir junto ao Ródano e depois junto ao Pó, e pela terceira vez em Trébia. Uma vez que sua pátria estava já exausta, requereu de Cipião uma trégua, para que combatessem em seguida com mais vigor. Aníbal teve um encontro com Cipião, mas não houve acordo com relação às condições de paz. Após tal acontecimento, poucos dias depois lutou com ele em Zama. Derrotado, Aníbal incrivelmente em dois dias e duas noites chegou a Adrumeto, aproximadamente trezentas milhas distante de Zama. Durante esta fuga, os Númidas que escaparam da batalha junto com ele armaramlhe uma emboscada, mas Aníbal não apenas deles se esquivou, como também os destruiu. Em Adrumeto, reuniu os que restaram da fuga e, com novos recrutamentos, reuniu em poucos dias muitos soldados.

[7] Quando Aníbal aplicava-se mais intensamente a estes preparativos, os cartagineses firmaram a paz com os romanos. Ele, mesmo depois disso, não deixou de presidir o exército; dirigiu a guerra na África ${ }^{318}$ até o consulado de Públio Sulpício e Gaio Aurélio. E eis que, durante tais magistraturas, embaixadores cartagineses vieram a Roma a fim de agradecer ao Senado e ao povo pela paz firmada e, em gratidão, ofereceram a eles uma coroa de ouro, e pediram o retorno dos prisioneiros, sendo que os reféns permaneceriam em Fregelas. A seguinte resposta, segundo a deliberação do Senado, lhes foi dada: que aceitavam e eram gratos pelo presente; que os reféns viveriam no lugar que solicitaram, mas que os prisioneiros não seriam devolvidos porque Aníbal, que havia sido a causa da guerra empreendida e era o maior inimigo do povo romano, até o presente momento tinha poder junto a seu exército, assim como seu irmão Magão. Tendo tomado conhecimento desta resposta, os cartagineses pediram que Aníbal e Magão retornassem à Cartago. Quando lá chegou, Aníbal, após de ter sido general por vinte e dois anos, foi

\footnotetext{
${ }^{316}$ Alguns manuscritos apresentam aqui "iter Mago frater eius”, suprimido por Bosius.
} 
annui bini reges creabantur.

In eo magistratu pari diligentia se Hannibal praebuit ac fuerat in bello. Namque effecit ex novis vectigalibus non solum ut esset pecunia quae Romanis ex foedere penderetur, sed etiam superesset quae in aerario reponeretur. Deinde ${ }^{317}$ M. Claudio L. Furio consulibus, Roma legati Karthaginem venerunt. Hos Hannibal ratus sui exposcendi gratia missos, priusquam iis senatus daretur, navem ascendit clam atque in Syriam ad Antiochum perfugit. Hac re palam facta, Poeni naves duas quae eum comprehenderent, si possent consequi, miserunt, bona eius publicarunt, domum a fundamentis disiecerunt, ipsum exulem iudicarunt.

[8] At Hannibal anno tertio postquam domo profugerat, L. Cornelio Q. Minucio consulibus, cum quinque navibus Africam accessit in finibus Cyrenaeorum, si forte Karthaginienses ad bellum Antiochi spe fiduciaque inducere posset, cui iam persuaserat ut cum exercitibus in Italiam proficisceretur. Huc Magonem fratrem excivit. Id ubi Poeni resciverunt, Magonem eadem qua fratrem absentem adfecerunt poena. Illi, desperatis rebus, cum solvissent naves ac vela ventis dedissent, Hannibal ad Antiochum pervenit. De Magonis interitu duplex memoria prodita est: namque alii naufragio, alii a servolis ipsius interfectum eum scriptum reliquerunt. Antiochus autem si tam in agendo bello consiliis eius parere voluisset, quam in suscipiendo instituerat, propius Tiberi quam Thermopylis de summa imperii dimicasset. Quem etsi multa stulte conari videbat, tamen nulla deseruit in re. Praefuit paucis navibus, quas ex Syria iussus erat in Asiam ducere, iisque adversus Rhodiorum classem in Pamphylio mari conflixit. Quo cum multitudine adversariorum sui superarentur, ipse quo cornu rem gessit nomeado rei ${ }^{319}$ : assim como se dava com os cônsules em Roma, em Cartago dois reis eram escolhidos a cada ano. No período de sua magistratura, Aníbal valeu-se da mesma diligência de que se valera na guerra. Pois, impondo novos tributos, conseguiu não só o dinheiro para pagar os romanos conforme o acordo de paz, mas também para além desta quantia, repondo assim o tesouro público. Em seguida, no consulado de Marco Cláudio e Lúcio Fúrio, embaixadores romanos vieram a Cartago. Aníbal seguro de que os enviados haviam vindo com o propósito de requerê-lo, antes que o Senado se encontrasse com eles, secretamente subiu em um navio e chegou à Síria, para junto de Antíoco. Quando este feito tornou-se conhecido, os Púnicos enviaram duas naus para apanhá-lo caso conseguissem segui-lo, confiscaram seus bens, destruíram sua casa desde a fundação, e declaram-no, por julgamento, exilado.

[8] Entretanto, Aníbal, no terceiro ano após ter fugido da pátria, durante o consulado de Lúcio Cornélio e Quinto Minúcio, com cinco naus chegou à África pelas regiões de Cirene, para verificar se poderia impelir os cartagineses à guerra com a esperança e confiança que Antíoco inspirava, rei a quem Aníbal já havia persuadido a marchar com os exércitos para a Itália. Para lá mandou ir também seu irmão Magão. Quando os Púnicos tomaram conhecimento deste fato, aplicaram a Magão, ausente, a mesma pena que de seu irmão. Eles, diante desta situação desesperada, lançaram as naus ao mar, entregando as velas aos ventos, e Aníbal retornou a Antíoco. Existem duas versões narradas sobre a morte de Magão: alguns escreveram que morreu em um naufrágio, outros que foi assassinado pelos próprios escravos. Antíoco, entretanto, se quisesse seguir os conselhos de Aníbal durante o desenvolvimento da guerra assim como o fez quando a declarou, teria lutado pelo sumo império mais próximo do Tibre que de Termópilas. Embora Antíoco percebesse que Aníbal tentava muitas ações de maneira insana, contudo em nenhuma empresa o abandonou. Comandou poucos navios, que havia ordenado conduzir da Síria para à Ásia, e com eles

\footnotetext{
${ }^{317}$ Os manuscritos apresentam neste local "anno post praeturam", suprimido por Fleck, e "praeturam" suprimido por Heusinger.

${ }^{318}$ Rolfe (1984) aponta que os manuscritos incluem neste local o trecho, itemque Mago frater eius, "assim como seu irmão Magão", excluído por Bosius.

${ }^{319}$ A edição que seguimos (Rolfe, Loeb, 1984) adota rex (Heusinger), mas aponta que outros manuscritos apresentam o termo praetor. Monginot (1882) aponta que Tito Lívio afirmou que Aníbal foi nomeado praetor, e Justino que fora nomeado cônsul. Trata-se com certeza de uma magistratura civil.
} 
fuit superior.

[9] Antiocho fugato, verens ne dederetur, quod sine dubio accidisset, si sui fecisset potestatem, Cretam ad Gortynios venit, ut ibi quo se conferret consideraret. Vidit autem vir omnium callidissimus in magno se fore periculo, nisi quid providisset, propter avaritiam Cretensium; magnam enim secum pecuniam portabat, de qua sciebat exisse famam. Itaque capit tale consilium. Amphoras complures complet plumbo, summas operit auro et argento. Has, praesentibus principibus, deponit in templo Dianae, simulans se suas fortunas illorum fidei credere. His in errorem inductis, statuas aeneas, quas secum portabat, omni sua pecunia complet easque in propatulo domi abicit. Gortynii templum magna cura custodiunt, non tam a ceteris quam ab Hannibale, ne ille inscientibus iis tolleret secumque duceret.

[10] Sic conservatis suis rebus, Poenus illusis Cretensibus omnibus, ad Prusiam in Pontum pervenit. Apud quem eodem animo fuit erga Italiam neque aliud quicquam egit quam regem armavit et exercuit adversus Romanos. Quem cum videret domesticis opibus minus esse robustum, conciliabat ceteros reges adiungebat bellicosas nationes. Dissidebat ab eo Pergamenus rex Eumenes, Romanis amicissimus, bellumque inter eos gerebatur et mari et terra. Sed utrobique Eumenes plus valebat propter Romanorum societatem. Quo magis cupiebat eum Hannibal opprimi; quem si removisset, faciliora sibi cetera fore arbitrabatur.

Ad hunc interficiundum talem iniit rationem. Classe paucis diebus erant decreturi. Superabatur navium multitudine; dolo erat pugnandum, cum par non esset armis. Imperavit quam plurimas venenatas serpentes vivas conligi easque in vasa fictilia combateu contra a frota dos Ródios no mar da Panfília. Embora os seus tenham nesta batalha sido superados por causa do grande número de inimigos, Aníbal venceu com flanco que comandou.

[9] Após Antíoco ter sido derrotado, Aníbal, temendo que fosse entregue, o que sem dúvida aconteceria se permitisse, veio até os Gortinos em Creta, para lá decidir para onde seguiria. Entretanto, o homem mais astuto de todos percebeu que estaria em grande perigo se não se precavesse contra a cobiça dos cretenses, pois carregava consigo grande quantidade de dinheiro, da qual sabia que havia boatos. Então realizou o seguinte plano: encheu várias ânforas com chumbo, e cobriu a superfície delas com ouro e prata. Entregou as ânforas no templo de Diana, na presença dos principais homens da cidade, simulando assim que entregava sua fortuna em lealdade a eles. Depois de ter enganado a todos, encheu com todo seu dinheiro algumas estátuas de bronze que levava consigo as colocou no pátio de sua casa. Os Gortinos guardavam o templo com grande cuidado, não por outros, mas por causa de Aníbal, para que esse não retomasse e levasse consigo nada sem que soubessem.

[10] Tendo desta maneira conservado suas posses, enganando a todos os cretenses, o cartaginês veio até o rei Prúsias, no mar Ponto ${ }^{320}$. Junto deste, Aníbal permaneceu com o mesmo ânimo contra a Itália e não buscou outra coisa senão armar o rei e afrontar os romanos. Vendo que os recursos desta corte não eram tão poderosos, Aníbal aproximava-se de outros reis e fazia alianças com outras nações guerreiras. Prúsias estava em desacordo com Eumênes, rei de Pérgamo e grande aliado de Roma. A guerra entre eles se dava por terra e mar, mas em ambos os territórios Eumênes era mais forte, por causa da aliança com os romanos. Por isso, o que Aníbal mais ansiava era destruí-lo; julgava que se o eliminasse, a outra guerra aconteceria mais facilmente.

Para matá-lo, adotou esta estratégia. Em poucos dias pretendiam travar uma batalha naval, e as embarcações de Eumênes eram em maior número; deveria lutar com algum artifício, já que

\footnotetext{
${ }^{320}$ Prúsias era rei da Bitínia, país localizado às margens do Ponto Euxino, hoje Mar Negro (Monginot, 1882). Nipperdey destaca o relato sobre a permanência de Aníbal om Prúsias é vaga, que apenas há a menção, também vaga, do encontro com Eumênes (Nipperday, 2002, 225).
} 
conici.Harum cum effecisset magnam multitudinem, die ipso quo facturus erat navale proelium classiarios convocat iisque praecipit, omnes ut in unam Eumenis regis concurrant navem, a ceteris tantum satis habeant se defendere. Id illos facile serpentium multitudine consecuturos. Rex autem in qua nave veheretur ut scirent se facturum; quem si aut cepissent aut interfecissent, magno iis pollicetur praemio fore.

[11] Tali cohortatione militum facta, classis ab utrisque in proelium deducitur. Quarum acie constituta, priusquam signum pugnae daretur, Hannibal, ut palam faceret suis quo loco Eumenes esset, tabellarium in scapha cum caduceo mittit. Qui ubi ad naves adversariorum pervenit epistulamque ostendens, se regem professus est quaerere, statim ad Eumenem deductus est, quod nemo dubitabat quin aliquid de pace esset scriptum. Tabellarius, ducis nave declarata suis, eodem unde erat egressus se recepit. At Eumenes soluta epistula nihil in ea repperit nisi quae ad irridendum eum pertinerent. Cuius etsi causam mirabatur neque reperiebat, tamen proelium statim committere non dubitavit.

Horum in concursu Bithynii
Hannibalis praecepto universi navem Eumenis adoriuntur. Quorum vim rex cum sustinere non posset, fuga salutem petit, quam consecutus non esset, nisi intra sua praesidia se recepisset, quae in proximo litore erant conlocata. Reliquae Pergamenae naves cum adversarios premerent acrius, repente in eas vasa fictilia de quibus supra mentionem fecimus conici coepta sunt. Quae iacta initio risum pugnantibus concitarunt, neque qua re id fieret poterat intellegi. Postquam autem naves suas oppletas conspexerunt serpentibus, nova re perterriti, cum quid potissimum vitarent non viderent, puppes verterunt seque ad sua castra nautica rettulerunt. Sic Hannibal consilio arma Pergamenorum superavit, neque tum solum, sed saepe alias pedestribus copiis pari não era páreo no número de armas. Ordenou que fossem apanhadas, vivas, quantas serpentes venenosas possíveis e que fossem guardadas em vasos de barro. Quando já haviam conseguido uma grande quantidade delas, no mesmo dia que se daria a batalha naval, Aníbal convoca ${ }^{321}$ os marinheiros e ordena-lhes que todos ataquem apenas uma nau, a do rei Eumênes, sendo que seria suficiente somente defender-se das demais. Isso facilmente seria possível graças à enorme quantia de serpentes. Acrescenta que faria com que soubessem em qual embarcação estava o rei, e promete uma grande recompensa àquele que ou $o$ capturasse ou o matasse.

[11] Dadas tais ordens aos soldados, as frotas de ambos os lados dirigem-se para o combate. Formada a linha de batalha dos navios, antes que o sinal da luta fosse dado, Aníbal, a fim de revelar aos seus em qual embarcação estava Eumênes, enviou um mensageiro em uma barca, portando o caduceu ${ }^{322}$ : ele foi diante das embarcações inimigas e, mostrando uma carta, declarou que procurava o rei. Imediatamente foi levado até Eumênes, pois ninguém duvidava de que o escrito era outra coisa que senão um acordo de paz. Tendo revelado para os seus desta maneira a nau do comandante, retornou para o mesmo lugar de onde partira. E Eumênes, ao abrir a carta, nada achou nela a não ser impropérios contra si. Embora espantado e sem entender o motivo disso, não hesitou em iniciar o combate imediatamente.

No encontro das duas frotas, os Bitínios todos, seguindo as ordens de Aníbal, atacaram o navio de Eumênes. Não podendo o rei defender-se da força deste ataque, fugiu para salvar-se, o que não teria conseguido se não tivesse se recobrado junto à defesa que estava disposta perto da praia. Quando as naus pergamenas restantes oprimiam o adversário mais severamente, subitamente começaram a cair os vasos de barro que mencionamos acima. No início, os vasos arremessados provocaram o riso dos que lutavam, pois esses não conseguiam compreender o que era aquilo. Porém, depois que viram suas embarcações cheias de serpentes, aterrorizados com esta situação inesperada e não sabendo do que se defender primeiro, recuaram e se dirigiram ao campo naval. Desta maneira, Aníbal superou pela

\footnotetext{
${ }^{321}$ Note-se aqui o uso do presente histórico; translatio temporum.

322 Monginot (1882) explica que o caduceu era uma vara de madeira em cuja extremidade havia duas serpentes entrelaçadas; era uma insígnia de Mercúrio.
} 
prudentia pepulit adversarios.

[12] Quae dum in Asia geruntur, accidit casu ut legati Prusiae Romae apud T. Quinctium Flamininum consularem cenarent, atque ibi de Hannibale mentione facta, ex iis unus diceret eum in Prusiae regno esse. Id postero die Flamininus senatui detulit. Patres conscripti, qui Hannibale vivo numquam se sine insidiis futuros existimarent, legatos in Bithyniam miserunt, in iis Flamininum, qui ab rege peterent ne inimicissimum suum secum haberet sibique dederet. His Prusia negare ausus non est; illud recusavit, ne id a se fieri postularent quod adversus ius hospitii esset: ipsi, si possent, comprehenderent; locum, ubi esset, facile inventuros. Hannibal enim uno loco se tenebat, in castello, quod ei a rege datum erat muneri idque sic aedificarat, ut in omnibus partibus aedificii exitus haberet, scilicet verens ne usu veniret quod accidit.

Huc cum legati Romanorum venissent ac multitudine domum eius circumdedissent, puer, ab ianua prospiciens, Hannibali dixit plures praeter consuetudinem armatos apparere. Qui imperavit ei ut omnes fores aedificii circumiret ac propere sibi nuntiaret num eodem modo undique obsideretur. Puer cum celeriter quid esset renuntiasset omnisque exitus occupatos ostendisset, sensit id non fortuito factum, sed se peti neque sibi diutius vitam esse retinendam. Quam ne alieno arbitrio dimitteret, memor pristinarum virtutum, venenum quod semper secum habere consuerat sumpsit.

\footnotetext{
[13] Sic vir fortissimus, multis variisque perfunctus laboribus, anno acquievit septuagesimo. Quibus consulibus interierit non convenit. Namque Atticus M. Claudio Marcello Q. Fabio Labeone consulibus mortuum in Annali suo scriptum reliquit, at Polybius L. Aemilio Paulo Cn. Baebio Tamphilo, Sulpicius autem Blitho P. Cornelio Cethego M. Baebio Tamphilo. Atque
}

astúcia as armas dos pergamenos: e não somente neste caso, mas em muitas outras vezes afastou os inimigos em batalhas terrestres com igual inteligência.

[12] Enquanto estes fatos ocorriam na Ásia, aconteceu por acaso que alguns embaixadores de Prúsias em Roma, em um jantar com Tito Quinto Flamínio, consular, fizeram menção a Aníbal, e um deles revelou que o cartaginês estava no reino de Prúsias. No dia seguinte, Flamínio delatou isso ao Senado. Os pais conscritos, que julgavam que enquanto Aníbal estivesse vivo nunca estariam livres de suas insídias, enviaram embaixadores à Bitínia, entre eles Flamínio, para pedir ao rei que não permanecesse com o maior inimigo romano $\mathrm{e}$ o entregasse. Prúsias não se atreveu a dizer que não, mas não aceitou que pedissem que fosse feito por ele algo que era contra as regras da hospitalidade: eles mesmos, se conseguissem, o prenderiam; facilmente achariam o lugar onde ele estava. De fato, Aníbal residia em um único lugar, um castelo dado pelo rei como presente, o qual havia construído de forma que em todos cômodos da casa havia uma saída, por temer que acontecesse isso que de fato ocorreu. Quando os embaixadores romanos, em grande número, ali chegaram e cercaram a casa, um escravo, que observa pela janela, disse a Aníbal que havia mais homens armados do que era costume. Ordenou ao escravo que percorresse todas as saídas da casa e o informasse depressa se do mesmo modo estavam todas bloqueadas. Quando rapidamente o escravo relatou o que viu e explicou que todas as aberturas estavam sitiadas, Aníbal entendeu que este fato não era fortuito, que haviam vindo para prendê-lo e que sua vida não seria conservada por muito mais tempo. Não querendo entregá-la à decisão de outro, recordando-se de seus feitos virtuosos do passado, tomou o veneno que costumava sempre levar consigo.

[13] Assim, o homem mais forte de todos, tendo realizado muitas e variadas empresas, repousou aos setenta anos de idade. Não há consenso sobre em qual consulado morreu. Pois Ático escreveu em seus Anais que foi morto no consulado de Marco Cláudio Marcelo e Quinto Fábio Labeão; mas Políbio afirma que foi no de Lúcio Emílio Paulo e Gneo Bébio Tânfilo, e Sulpício Blitho ${ }^{323}$ no de Públio Cornélio Cetego e

\footnotetext{
${ }^{323}$ A maioria dos manuscritos traz "Sulpicius Blitho", inexistente no Codex Leidensis e no Codex Collegi Romani (Monginot, 1882). Nipperday afirma ser um historiador romano, mas apenas mencionado por Nepos, neste
} 
hic tantus vir tantisque bellis districtus non nihil temporis tribuit litteris. Namque aliquot eius libri sunt, Graeco sermone confecti, in iis ad Rhodios de Cn. Manlii Volsonis in Asia rebus gestis. Huius belli gesta multi memoriae prodiderunt, sed ex iis duo, qui cum eo in castris fuerunt simulque vixerunt, quamdiu fortuna passa est, Silenus et Sosylus Lacedaemonius. Atque hoc Sosylo Hannibal litterarum Graecarum usus est doctore.

Sed nos tempus est huius libri facere finem et Romanorum explicare imperatores, quo facilius, collatis utrorumque factis, qui viri praeferendi sint possit iudicari.
Marco Bébio Tânfilo. E este homem grandioso, que se ocupou de tantas guerras, dedicou ainda tempo às Letras. Pois existem alguns livros seus, escritos em grego, entre eles um, dirigido aos Ródios, sobre os feitos de Cneu Mânlio Volso na Ásia. Muitos relatos registraram os acontecimentos da guerra gerida por Aníbal, mas dentre eles há dois cujos autores, Sósilo, lacedemônio, e Sileno $^{324}$, estiveram no acampamento e com ele viveram enquanto a fortuna permitiu. $\mathrm{E}$ foi este Sósilo que Aníbal teve como professor das letras gregas.

Mas nos é chegado o momento de finalizar este livro e narrar a vida dos comandantes romanos, para que, comparando os feitos de uns e outros, mais facilmente se julgue quais homens devem ser colocados em primeiro lugar.

local. Monginot, considerando os manuscritos nos quais há apenas "Sulpicius", afirma que poderia ser o Sulpício Galba que Suetônio menciona como ancestral do imperador Galba e que Cícero descreve como um orador distinto, ou o Sulpício Galo, outro orador que Cícero menciona no capítulo vigésimo de Bruto, e ainda houve o famoso Sulpício Rufo, tribuno da plebe.

${ }^{324}$ O nome de um historiador Sileno é encontrado também em Tito Lívio, 36.49, e em Cícero, De Div. 1.24. 0 historiador Sosilus é mencionado por Diodoro, Eclog. 26.3, e por Políbio, 3.20, sendo acusado de não ser um historiador sério (Monginot, 1882). 